\title{
GONÇALO M. TAVARES E OS SEUS SENHORES
}

Tese apresentada para defesa de Doutorado na área de Literatura Portuguesa.

Departamento: Letras Clássicas e Vernáculas da Faculdade de Filosofia, Letras e Ciências Humanas da Universidade de São Paulo.

Orientadora: Prof ${ }^{\underline{a}}$ Dr ${ }^{\underline{a}}$ Lílian Lopondo.

Este exemplar corresponde à versão corrigida da tese, segundo sugestões da banca examinadora, com autorização da orientadora da tese, Prof ${ }^{a}$ Dr$^{\mathrm{a}}$ Lílian Lopondo. O exemplar original encontra-se disponível no Centro de Apoio à Pesquisa Histórica da Faculdade de Filosofia, Letras e Ciências Humanas da Universidade de São Paulo.

De acordo:

Profa Dra. Lílian Lopondo

São Paulo 
Liani Fernandes de Moraes

Título: Gonçalo M. Tavares e os seus Senhores

Tese apresentada para defesa de Doutorado na área de Literatura Portuguesa

Departamento: Letras Clássicas e Vernáculas da

Faculdade de Filosofia Letras e Ciências

Humanas da Universidade de São Paulo

Aprovada em: 19/03/2012

\section{Banca Examinadora}

Prof ${ }^{a}$. Dr ${ }^{a}$ Munira Hamud Mutran

Julgamento:

Prof ${ }^{a}$. Dr ${ }^{\mathrm{a}}$. Aurora G. Ruiz Alvarez

Julgamento:

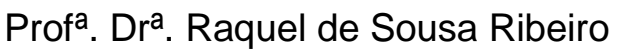

Julgamento:

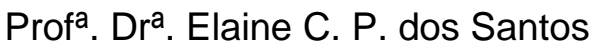

Julgamento:
Universidade de São Paulo

Assinatura:

Universidade Presbiteriana Mackenzie

Assinatura:

Universidade de São Paulo

Assinatura:

Universidade Presbiteriana Mackenzie

Assinatura:

Orientadora:

Prof ${ }^{a}$. Dra . Lílian Lopondo 
Aos meus pais, Brasília Barreto Fernandes e Manoel Anibal Fernandes, por tudo que sou.

Aos meus irmãos, Marcio e Marcia, pelo carinho e apoio constantes.

Ao meu marido, José Carlos, e ao meu filho, Ivan, pelo amor que nos mantém unidos. 


\section{AGRADECIMENTOS}

Aos meus pais, Aníbal e Brasília, pelo amor e incentivo constantes.

À minha querida orientadora, Prof ${ }^{a}$ Dra $^{\text {a }}$ Lílian Lopondo, pelo carinho, pela paciência, pelo estímulo e por sua orientação firme e competente.

Aos Professores da Pós-Graduação em Letras da Universidade Presbiteriana Mackenzie e aos Professores do Programa de Pós-Graduação da Universidade de São Paulo, com quem muito aprendi.

À Prof ${ }^{-}$Dr $^{\text {a }}$ Raquel de Sousa Ribeiro, da Universidade de São Paulo, pelas valiosas orientações e sugestões apresentadas por ocasião do Exame de Qualificação, e por sua participação e contribuições em minha banca de defesa.

À Prof ${ }^{a}$ Dr ${ }^{\underline{a}}$ Aurora Gedra Ruiz Alvarez, da Universidade Presbiteriana Mackenzie, pelas orientações e sugestões extremamente úteis apresentadas por ocasião do Exame de Qualificação, bem como por sua participação e contribuições em minha banca de defesa.

À Prof ${ }^{-}$Dr$^{a}$ Munira Hamud Mutran, da Universidade de São Paulo, por sua participação e contribuições em minha banca de defesa.

À Prof ${ }^{a}$ Dr ${ }^{\text {a }}$ Elaine Cristina Prado dos Santos, da Universidade Presbiteriana Mackenzie, por sua participação e contribuições em minha banca de defesa.

Aos amigos queridos e sempre presentes: Eliane Person, Mercedes Lopes Guelli, Oscar Augusto Guelli Neto e Carlos Emílio Faraco.

Aos colegas professores das instituições onde trabalhei. Aos meus atuais colegas, professores da FESP - Fundação Escola de Sociologia e Política de São Paulo, pelo apoio que nunca me faltou. 
À Marcia Cristina, professora exemplar, guia e lastro, querida irmã e companheira.

Ao meu marido, José Carlos, ao meu filho, Ivan, ao meu irmão, Marcio Antonio, aos meus cunhados e sobrinhos, tão carinhosos sempre.

Aos queridos Kíron, Cléo, Kaila e Kiara, companheiros fiéis de tantas madrugadas. 
"[...] a noite tem dois lados e a poesia é a porta da casa no momento em que é aberta e o escuro cobre a relva e o céu. Mas quando alguém tem medo, deve correr para casa; e quando sente tédio, deve correr para a parte de fora da noite. E a poesia, que parece uma coisa parada, resolve, ao mesmo tempo, o tédio e o medo; o que é bom e dois, sendo uma única, a poesia" (O senhor Breton) ${ }^{1}$.

${ }^{1}$ TAVARES, Gonçalo M. O senhor Breton e a entrevista. Rio de Janeiro: Casa da Palavra, 2009, p. 11. 


\section{RESUMO}

A partir da Teoria dos Cronotopos, concebida por Mikhail Bakhtin, esta tese busca mostrar os modos pelos quais a fusão de tempo/espaço determina 0 enredo e as posturas das personagens em sua interação com o Outro, na obra Os Senhores, de Gonçalo M. Tavares. Vivendo como indivíduos descentrados, segundo lógicas próprias, as personagens também apresentam problemas identitários e de relacionamento com a alteridade. Além disso, por meio da análise dos elementos composicionais dos discursos e do estudo dos protogêneros pretendemos estabelecer alguns dos possíveis sentidos das narrativas, principalmente aqueles relacionados à realidade do homem contemporâneo.

Palavras-chave: cronotopos - enredo - alteridade - contemporaneidade identidade 


\begin{abstract}
From the ideas conveyed by Mikhail Bakhtin's Theory of Chronotopes, we seek to demonstrate the ways through which the fusion of time/space determines both the plot and the characters' postures in their interactions with the alterity, in the series Os Senhores, written by Gonçalo M. Tavares. The fact of living as off-centered individuals, with their peculiar forms of logic, also causes them to present identity and relationship problems with the Other. Besides, through the analysis of the elements which constitute their discourses, parallel to the study of the prototypes, we intend to establish some of the possible meanings contained in the stories, especially those related to contemporary man's reality.
\end{abstract}

Key words: chronotopes - plot - alterity - contemporary period - identity 
ÍNDICE DE ILUSTRAÇÕES

A tortura do senhor Breton ...................................................... 75

A casa do senhor Walser ......................................................... 137

O problema da altura do senhor Valéry ................................... 162

O bicho de estimação do senhor Valéry ........................................ 163

A esposa do senhor Valéry ....................................................... 164

A casa de férias do senhor Valéry .............................................. 175

A casa das quatro portas juntas ............................................... 176

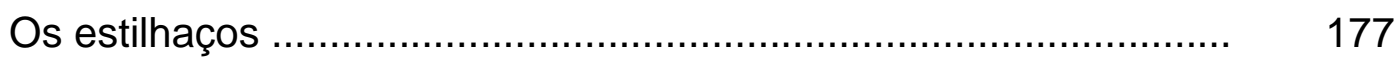

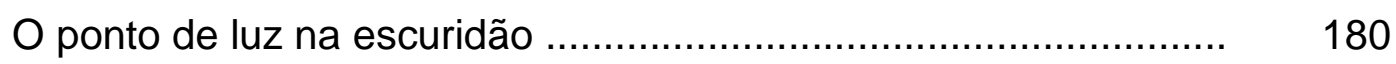

Os trajetos do senhor Calvino I ............................................ 208

Os trajetos do senhor Calvino II ......................................... 209

O contador de histórias ...................................................... 243

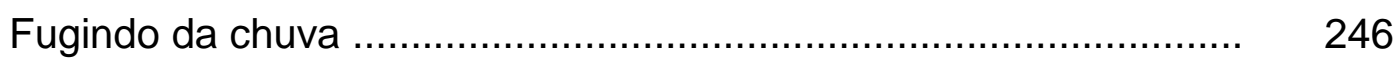

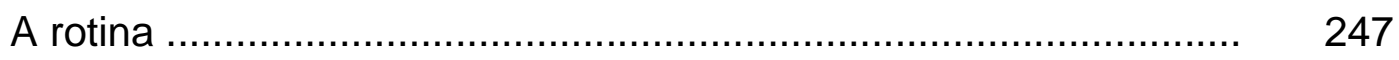

Os dois lados que as coisas têm ........................................... 257 
SUMÁRIO

Índice de ilustrações ............................................................... 9

Sobre Gonçalo M. Tavares ...................................................... 11

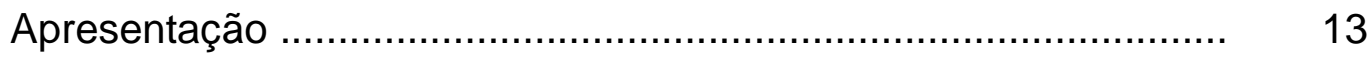

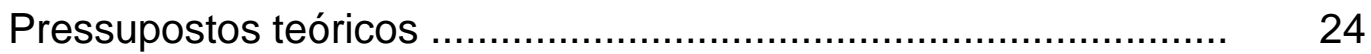

Capítulo I: Tempo e espaço nO Bairro ........................................... 27

Capítulo II: A cada senhor o que the pertence .............................. 110

II. 1 Consciência e busca: o senhor Breton e o senhor Calvino .... 112

II. 2 O idílio desfeito e o senhor Walser .......................................... 137

II. 3 Poder e denúncia: o senhor Brecht e o senhor Kraus ............ 143

II. 4 O medo e o método: o senhor Valéry e o senhor Juarroz ..... 161

II. 5 Eu e Vossas Excelências: o senhor Henri .............................. 181

Capítulo III: O discurso do limiar ................................................. 200

Considerações finais ................................................................. 285

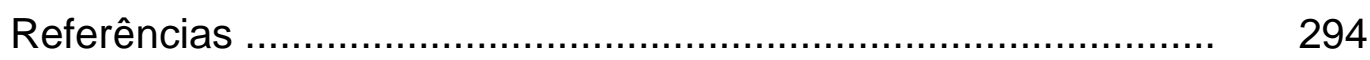

Anexo 1 - O Bairro …….......................................................... 302

Anexo 2 - Três entrevistas de Gonçalo M. Tavares .................... $\quad 303$

Anexo 3 - Gonçalo M. Tavares na visão de críticos e autores ..... 327

Anexo 4 - Obras e premiações de Gonçalo M. Tavares ................ 332 


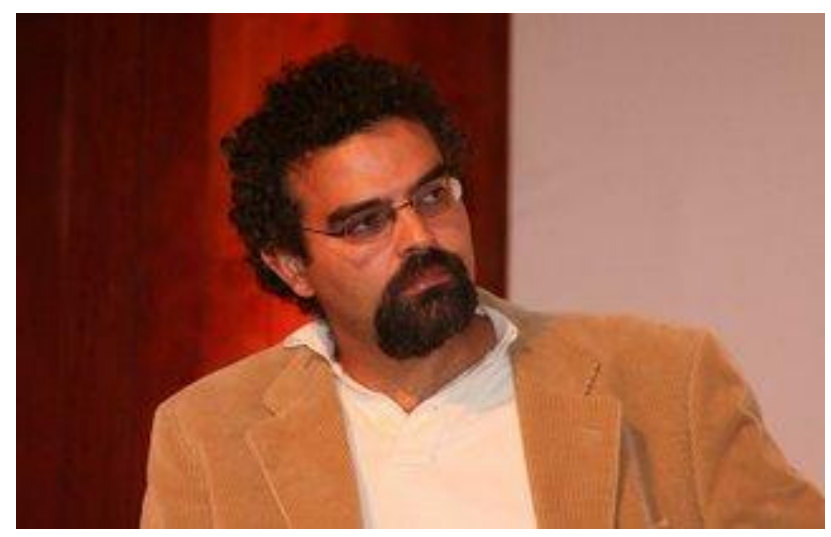

\section{Gonçalo M. Tavares na Biblioteca José Saramago²}

Entre os nomes da nova Literatura Portuguesa, Gonçalo M. Tavares situa-se entre os mais importantes.

O autor nasceu em Luanda, Angola, em 1970, tendo passado sua infância em Aveiro. Publicou sua primeira obra, Livro da dança, em 2001. A partir daí seguiram-se muitas outras, entre elas o romance Jerusalém, que recebeu o Prêmio José Saramago 2005, o Prêmio Ler/Millenium-BCP e o Prêmio Portugal Telecom de Literatura 2007, no Brasil.

Ganhador de vários prêmios nacionais e internacionais, seus livros deram origem, em diversos países, a peças teatrais, vídeos, curtas-metragens, objetos de arte, espetáculos de dança, performances, projetos de arquitetura, trabalhos acadêmicos, entre outras obras.

Além de escritor, Gonçalo M. Tavares é professor universitário em Lisboa. Estão em curso, cerca de 210 traduções de suas obras, distribuídas por quarenta países.

Cito aqui o elogio que the fez José Saramago no discurso de atribuição do Prêmio que leva o seu nome, dado ao romance Jerusalém, em 2005: "Jerusalém é um grande livro, que pertence à grande literatura ocidental.

${ }^{2}$ Foto disponível em: http://lernaoecrime.blogspot.com.br/2011/10/goncalo-m-tavares-e-joaotordo-na.html. 
Gonçalo M. Tavares não tem o direito de escrever tão bem apenas aos 35 anos: dá vontade de lhe bater!"

Em seu blogue, "O Caderno de Saramago", o autor elogia, ainda, a "imaginação totalmente incomum" de Gonçalo M. Tavares, possuidor de "uma linguagem muito própria, em que a ousadia vai de braço dado com a vernaculidade". E prossegue: "Vaticinei-Ihe o Prémio Nobel para daqui a trinta anos, ou mesmo antes, e penso que vou acertar".

O Anexo 2 traz algumas entrevistas de Gonçalo M. Tavares, concedidas a alguns órgãos de imprensa, enquanto o Anexo 3 apresenta a visão de alguns críticos e escritores acerca de sua obra.

O Anexo 4 apresenta a relação completa da obra do autor, bem como de suas premiações até o momento da defesa desta tese. 


\section{APRESENTAÇÃO}

O objetivo deste trabalho é proceder à análise da obra Os Senhores, do escritor angolano Gonçalo M. Tavares, tendo como base teórica a Teoria dos Cronotopos de Mikhail Bakhtin.

Trata-se de um conjunto de narrativas, cujos títulos correspondem a nomes de conhecidas personalidades da cultura, especialmente da palavra escrita.

São os seguintes os títulos já publicados no Brasil, pela ordem de data de publicação: O senhor Valéry (2004a), O senhor Henri (2004b), O senhor Brecht (2005), O senhor Juarroz (2007a), O senhor Kraus (2007b), 0 senhor Calvino (2007c), O senhor Walser (2008) e O senhor Breton e a entrevista (2009).

A obra será completada com outros livros, além dos oito publicados até o momento no Brasil, e dos dez editados em Portugal.

Graficamente, o autor demonstra a configuração dO Bairro com seus atuais moradores, como se pode ver no Anexo 1, apontando para a criação de futuras personagens, já com seus locais de moradia identificados por seus nomes. São eles: o senhor Rimbaud, o senhor Balzac, o senhor Carroll, o senhor Melville, o senhor Proust, o senhor Cortázar, o senhor Gogol, o senhor Eliot, a senhora Woolf, o senhor Burroughs, o senhor Wells, o senhor Joyce, o senhor Kafka, o senhor Mishima, o senhor C. Andersen, o senhor Lorca, o senhor Swendenborg, a senhora Bausch, o senhor Loyd Wright, o senhor Corbusier, o senhor Duchamp, o senhor Warhol, o senhor Pirandello, o senhor Pessoa, o senhor Borges, o senhor Orwell, o senhor Beckett, o senhor Wittgenstein, o senhor Foucault, o senhor Musil, e o senhor Voltaire.

Nosso primeiro contato com a obra do autor se deu pela leitura do romance Jerusalém (2006), que nos instigou para outras leituras de Gonçalo M. Tavares, as quais, finalmente, nos conduziram à decisão da escolha da obra Os Senhores como objeto da tese de doutorado. 
O que primeiro chama a atenção em Os Senhores, de Gonçalo M. Tavares, é o inusitado que se instala entre o leitor e a obra. Tal característica de estranhamento, pela identificação do que é incomum, consiste em uma espécie de nonsense narrativo, que nos faz interromper a leitura e voltar atrás para reler, instigando-nos a pensar. É também o que nos faz ir além, encontrando outros tipos de lógica propostos pelas narrativas, as quais, rompendo com a ortodoxia, nos põem diante do inesperado.

Outro aspecto a despertar nosso interesse está na construção das personagens, sujeitos da contemporaneidade, complexos, fragmentados, que se escondem sob traços de ingenuidade, às vezes beirando o pueril, mas que, aos poucos, desvelam suas intrincadas maneiras de ser, mostrando seus pontos fracos, suas rupturas, suas superações.

Moradores dO Bairro, os senhores Valéry, Kraus, Breton, Walser, Brecht, Calvino, Henri e Juarroz, cada um ao seu modo, expõem suas realidades, visões de mundo, problemas cotidianos e existenciais, suas relações com o entorno, suas formas de encarar a vida e de resolver problemas. Tais elementos são organizados e mediados a partir de e pelos cronotopos. Assim, os conceitos de tempo e espaço, como unidade literária inseparável, são determinantes para o desenvolvimento dos enredos das narrativas.

A obra Os Senhores constitui-se, pois, de narrativas curtas, que não podem, todavia, ser denominadas de contos nem fábulas, embora contenham elementos pertencentes a diversos gêneros e protogêneros em prosa, incluindo o romance. Na verdade, o autor constrói instantâneos da realidade sui generis de cada senhor, provocando o leitor de modo a que se posicione diante de eventos aparentemente insólitos, cômicos, irrelevantes ou sem sentido, cruéis, demagógicos, irônicos, trágicos e, muitas vezes, irracionais. Há, contudo, uma lógica própria, que se autorreferencia, costurando as porções narrativas entre si, e conferindo à obra artístico-literária a característica peculiar de ser única.

Do ponto de vista diegético, e à medida que se revelam as aparentes patologias comportamentais das personagens, fica exposta a realidade subvertida de suas realidades. Trata-se de um mundo às avessas, que molda $e$ 
conforma cada um dos senhores de acordo com modelos distintos, o que também se procura evidenciar por meio deste trabalho.

Gonçalo M. Tavares cria personagens e enredos, segundo desenhos assimétricos em relação a narrativas que apresentam verossimilhança com a realidade tal qual a vivenciamos cotidianamente, devendo a obra ser, portanto, investigada, conforme seus próprios parâmetros. Qualquer tentativa de análise que tente aproximá-la do "real" ou do formalismo da lógica cartesiana segundo os conhecemos, distanciará o analista e pesquisador da proposta criativoliterária do autor.

A obra deste jovem escritor angolano se firma como uma nova narrativa, valendo-se de elementos linguísticos, extralinguísticos e literários, que se não são inéditos de forma absoluta, relativizam de modo peculiar e único aspectos presentes em outros gêneros e estilos narrativos, criando, desse modo, uma nova maneira de narrar, a qual busca aproximar o leitor de um espaço de reflexão inusitado, que não pretende ser pedagógico ou ditador de regras, mas antes, é construído de forma a confrontar arte e mundo, questionando valores, temas, posições, ambiguidades, paradoxos, dualidades e fragmentações, elementos constitutivos do homem e da sociedade da pós-modernidade.

Mesclando paródias de estilos, O Bairro estabelece-se, pois, como a praça pública da exposição carnavalesca, palco em que dialogam questões literárias, estéticas e de cunho social, e onde nada é o que parece ser. É, portanto, o tempo/espaço da suposta dessemelhança, do absurdo, do paradoxal, do anticonvencional, a reger as disputas de posicionamento e confronto, em que uma visão aparentemente pessimista, mantém o olhar na direção da utopia.

Vale dizer que o processo de carnavalização descrito por Bakhtin pressupõe o momento de exceção em meio à rotina predominante. Tal processo não constitui, desde a Antiguidade, uma forma específica de espetáculo, mas a encenação da própria vida encarada pelo viés do riso, autorizado durante certo período.

O que se observa em Os Senhores é o fato de que a vida cotidiana que levam as personagens apresenta em si mesma uma vivência carnavalizada 
intrínseca, com poucas inserções da lógica formal, ou de padrões regulares, que servem apenas para realçar a visão proposta de ruptura com o que se poderia chamar de vida em seu curso normal.

Segundo o teórico russo, "[...] o carnaval não era uma forma artística de espetáculo teatral, mas uma forma concreta (embora provisória) da própria vida, que não era simplesmente representada no palco, antes, pelo contrário, vivida enquanto durava o carnaval" (BAKHTIN, 2008, p. 6).

Tomando ainda, de acordo com a acepção bakhtiniana, a cultura como fenômeno da língua, tem-se, a partir da obra de Tavares, a construção pela palavra das dimensões cognitivas, estéticas e éticas de todos os elementos que compõem a vida dO Bairro. É o relacionamento do autor-criador com os vários campos do conhecimento, expressos pela palavra, que vai constituir 0 objeto estético - a própria narrativa, cabendo ao leitor, penetrar, em segunda instância, o que o autor, em primeira instância, concebeu.

Segundo Bakhtin, "[...] é preciso fazer do que é visto, ouvido e pronunciado a expressão da nossa relação ativa e axiológica; é preciso ingressar como criador no que se vê, ouve e pronuncia, e desta forma superar o caráter determinado, material e extra-estético (sic) da forma, seu caráter de coisa: ela deixa de existir no nosso exterior como um material percebido e organizado de modo cognitivo, transformando-se na expressão de uma atividade valorizante que penetra no conteúdo e o transforma. Deste modo, durante a leitura ou a audição de uma obra poética, eu não permaneço no exterior de mim, como o enunciado de outrem, que é preciso apenas ouvir e cujo significado prático ou cognitivo é preciso apenas compreender; mas numa certa medida, eu faço dele meu próprio enunciado acerca de outrem, [...] envolvo-o, formo-o e arremato-o [...]. Assim, a forma é a expressão da relação axiológica ativa do autor-criador e do indivíduo que percebe (co-criador da forma) com o conteúdo; [...]" (BAKHTIN, 1988, p. 58-59).

O objetivo primordial que se busca com este trabalho é, pois, estabelecer os modos pelos quais as relações de tempo/espaço funcionam como determinantes para o desenvolvimento das tramas, em que não apenas os conceitos apresentados pelas personagens são aparentemente transgressores, mas também, e especialmente, as peculiaridades cronotópicas 
são capazes de criar o terreno propício para o desenvolvimento dos enredos, os quais contrariam os parâmetros da lógica formal.

Assim, os cronotopos constituem a configuração têmporo-espacial sobre a qual as personagens se posicionam nas narrativas, por sua voz, sua entoação emocional e suas ações, gerando as relações de causa e efeito, o encadeamento das cenas, a construção imagética e psicológica das personagens e de suas linguagens.

Também a definição do papel do narrador, assim como o impacto que as histórias têm sobre o leitor levam em conta não apenas o conteúdo do que é narrado, mas as maneiras, segundo as quais, são conduzidas as sequências narrativas nas histórias, com base nos cronotopos que as determinam.

Trata-se, acima de tudo, de tentar penetrar alguns dos múltiplos sentidos que a obra oferece. Tal percepção do sentido narrativo se consubstancia à vista de um onde e de um quando interligados, regentes das ações das personagens e da construção do enredo em si, tanto no que se refere ao conteúdo quanto à forma.

Tais tempos e espaços são os determinantes causais e semânticos das ações nos enredos, dirigindo e engendrando as falas das personagens, configurando as vozes primordiais e as secundárias em suas entoações específicas, estabelecendo, por essa via, a coloração emotiva do que é narrado. Em suma, a configuração cronotópica funciona no sentido de interligar de modo dialógico as partes que resultarão nos possíveis sentidos propostos pela obra.

Pode-se afirmar que a compreensão dos cronotopos sob a perspectiva da configuração do enredo pode ser entendida aqui como o método de capturar o tempo e o espaço narrativos, de forma que os sentidos sejam estruturados a partir das ações das personagens na dinâmica do contexto têmporo-espacial em que ocorrem tanto no aspecto da narração encadeada pelo autor ao longo da obra, como no aspecto interpretativo, que cabe ao leitor e ao analista.

Segundo Bakhtin (1986, p. 21), tal incorporação imagético-emocional do tempo e do espaço em relação ao herói acaba por constituí-lo e ao seu ambiente, o que resulta em suas ações, suas falas e seu destino em relação à 
semântica geral da obra, de tal forma que "o tempo é introduzido no homem, entra na sua imagem, mudando de forma fundamental o significado de todos os aspectos do destino e da vida". Daí o maior destaque dado ao tempo como condutor diegético do que ao espaço. E, como grandeza mutável, o cronotopo varia segundo o sentido que o autor quer imprimir à obra, seja como um constructo completo ou a partes dela.

O tempo-espaço não é, pois, um dado definido de uma vez e, portanto, fixado como tal do começo ao fim da história. O tempo, por seu turno, se incorpora à personagem e a seu trajeto histórico na narrativa, com mudanças de percurso, variações de duração e rupturas, respondendo por transformações pessoais, sociais e culturais.

Assim, as maneiras pelas quais o homem vê a si mesmo e ao seu mundo, e que não são estáveis no eixo diacrônico, são estabelecidas por seus posicionamentos temporais e espaciais. Trata-se de um processo emotivo e psicológico que envolve as personagens e as suas ações, e do qual depende a construção dos significados.

Vale ressaltar, ainda, que o conceito de cronotopo, segundo a teoria bakhtiniana, envolve necessariamente o homem e a cultura na qual ele se insere, abrangendo influências de ordem social e política, e ultrapassando a visão meramente biológica do indivíduo como parte da natureza, sem marcas de historicidade. A temporalidade narrativa estabelece-se, por conseguinte, como diversa do tempo dos fenômenos naturais, caracterizando-se a cultura como "[...] fator principal para dar forma às mentes daqueles que viviam [e vivem] sob sua influência" (BRUNER, 1997, p. 22).

Portanto, a concomitância de tempo e espaço permite que se estabeleçam conexões entre as personagens e os contextos em que se situam, tanto em termos da ação propriamente dita, como dos modos de seu desenvolvimento, balizando posicionamentos nas várias camadas de sentido propostas.

Tal interação de tempo e espaço propicia, ainda, a "leitura" referente a aspectos históricos e da natureza, bem como os da esfera dos costumes, das ideias e experiências humanas como um todo. Assim, "A emergência do 
homem é capturada no tempo histórico real, com todas as suas necessidades, sua completude, seu futuro, e sua natureza profundamente cronotópica" (BAKHTIN, 1986, p. 23).

$\mathrm{Na}$ visão bakhtiniana, o cronotopo é, portanto, o elemento determinante da unidade artística de uma obra literária no que concerne à sua realidade como tal. Destarte, para o autor, "A arte e a literatura estão impregnadas por valores cronotópicos de diversos graus e dimensões" (BAKHTIN, 1988, p. 349, grifo do autor).

Discorrer-se-á, a seguir, sobre as possíveis correspondências de cronotopia entre a referida teoria de Mikhail Bakhtin e os cronotopos específicos da obra de Gonçalo M. Tavares, Os Senhores, estabelecendo, desse modo, as diferenças e os pontos de convergência entre a teoria e a obra, os quais buscam explicar as referências de tempo e espaço nas narrativas sob análise.

Uma dessas diferenças refere-se à distinção entre o cronotopo do encontro, conforme descrito por Bakhtin, e o mesmo cronotopo em Os Senhores. Na série de Gonçalo M. Tavares, é como se se pudesse falar, além de um cronotopo do encontro propriamente dito, de um "cronotopo do encontro em potencial”, ou seja, de um "cronotopo da expectativa do encontro", algo que é almejado pelos senhores, mas que pode ou não vir a acontecer, já que um dos pontos importantes da obra do autor consiste na construção de personagens, no caso, os senhores, que apresentam como sua maior dificuldade, o fato de não conseguirem estabelecer relacionamentos e vínculos estáveis com o Outro.

Segundo a teoria bakhtiniana, no cronotopo do encontro (Idem, p. 350) predomina a tonalidade temporal, com grande intensidade emotiva. Vinculado a ele, há o cronotopo da estrada, que apresenta menor intensidade emocional ocorrendo, porém, em uma maior amplidão espacial, tomado aí como referência para os encontros casuais em sua maior parte.

De acordo com o teórico russo, em um único ponto espaço-temporal, cruzam-se os caminhos das pessoas, as quais se distinguem por seus variados matizes socioculturais: de classes, idades, nacionalidades e religiões. 
Indivíduos separados por um ou mais desses atributos encontram-se na estrada e têm seus destinos entrelaçados a partir desses encontros, os quais objetivam, muitas vezes, encurtar as distâncias sociais. Assim é que, segundo Bakhtin (Ibid., p. 350), se configura "o caminho da vida", o fato de "ingressar numa nova estrada", ou "o caminho histórico", todas essas vias sustentadas pelo transcurso do tempo, o que se busca identificar com este trabalho nas narrativas de Gonçalo M. Tavares.

Em Os Senhores, tanto o cronotopo do encontro como o da estrada, ganham um caráter peculiar e diferenciado, segundo o próprio teor diegéticoemocional do que é narrado. Com relação às personagens, tais cronotopos dão ensejo a narrativas que se passam, em grande parte, no espaço público externo, a rua, contexto em que se inserem as personagens quando deixam a casa ou o trabalho em direção a algum lugar. É durante esses percursos que acontecem os eventuais encontros.

Além dos cronotopos da estrada e do encontro, o tempo/espaço da sala de visitas é igualmente importante, especialmente porque, como os outros dois, ele é frequente na obra de Gonçalo M. Tavares. Nele se dão os encontros, já não mais fortuitos, conforme os explicitados pelo autor nos cronotopos da estrada e do encontro, podendo, no caso da obra tavariana, ser no bar, como ocorre com o senhor Henri; em casa, como é o caso do senhor Juarroz; ou em uma espécie de auditório, como é o caso do senhor Brecht.

No cronotopo da sala de visitas, instala-se o que Bakhtin chama de "barômetro da vida política e dos negócios". Aí também se constroem e destroem reputações, carreiras principiam e fracassam. Segundo o autor, neste cronotopo,

[...] estão em jogo os destinos da alta política e das altas finanças, [...]; nele estão representadas de forma bem completa (e reunidas num único lugar e num único tempo) as gradações da nova hierarquia social; finalmente, revela-se em formas visíveis e concretas o poder onipresente do novo dono da vida - o dinheiro (Ibid. p. 352, sublinhado nosso). 
No caso das personagens de Tavares, a manutenção, em geral, do status quo, sem alterações no rumo das ações cotidianas dos senhores, sinaliza sua principal característica no plano diegético, que é a dificuldade de aproximação em relação ao Outro, o semelhante, ainda que todos desejem, de maneiras diversas, que isso ocorra.

$\mathrm{Na}$ verdade, as personagens das narrativas sob análise anseiam por relacionar-se, manifestando este desejo claramente ou não. Todavia, tal vontade é obstaculizada por vários impedimentos intrínsecos à própria maneira de ser das personagens, o que Ihes dificulta ou as impede de aproximar-se e criar vínculos estáveis com a alteridade em geral.

O cronotopo do encontro está, por conseguinte, conectado a aspectos emocionais e psicológicos, e aí reside a sua densidade. Cada um ao seu modo, os senhores, cujas idiossincrasias mal preenchem seu vazio afetivo, são, na verdade, carentes do convívio humano, e, ao mesmo tempo, mostram-se incapazes de articular mudanças comportamentais que permitam alterar tal estado de coisas. Este aspecto será discutido em pormenor no Capítulo II, que trata da relação Eu-Outro.

Quanto ao tempo/espaço, há uma importante relação entre as personagens, suas falas e ações com referência às tramas. $O$ ponto comum entre elas consiste no inusitado dos comportamentos dos senhores, que se reflete em suas maneiras individuais e peculiares de ver o mundo e de interagir com o Outro. A partir disso, o nosso objetivo principal neste trabalho consiste em demonstrar as maneiras pelas quais as relações têmporo-espaciais determinam o desenvolvimento do enredo, influenciando igualmente as posturas, as falas e as ações das personagens.

Assim, a questão dos cronotopos remete a outro aspecto marcante, que é o da significação por eles determinada, já que todo e qualquer fenômeno permite ser interpretado, isto é, ele se integra não apenas à existência espaçotemporal, mas também à esfera semântica, a qual the confere sentido. Tais significados, não importando quais sejam, estão inscritos em uma expressão de tempo e espaço que Bakhtin (Ibid., p. 362, grifo do autor) chama de forma sígnica, a qual se pode ver e ouvir, e a partir da qual se desenvolvem reflexões abstratas. Portanto, para o teórico, "[...] qualquer intervenção na esfera dos 
significados só se realiza através da porta dos cronotopos" (Ibid., p. 362). Daí a importância dos estudos bakhtinianos como substrato teórico indispensável para a análise da obra literária em questão.

O trabalho se estrutura em três capítulos, referentes aos tópicos desenvolvidos.

O Capítulo I, Tempo e espaço nO Bairro, tem como objetivo a análise dos modos pelos quais as grandezas têmporo-espaciais, segundo a Teoria dos Cronotopos formulada por Mikhail Bakhtin, se configuram como determinantes diegéticos, com influência sobre as relações dialógicas das personagens entre si, e destas com outros elementos da cultura, segundo paradigmas de tempo/espaço específicos.

A seguir, o Capítulo II, A cada senhor o que the pertence, aborda as características constitutivas das personagens, em seus aspectos identitários, suas formas de ser e de estar no mundo, bem como suas relações com a alteridade.

Finalmente, o Capítulo III, O discurso do limiar, tem como foco investigativo as falas das personagens, seus diálogos e réplicas nos vários contextos narrativos.

Vale ressaltar que, neste capítulo, procederemos ao estudo dos aspectos morfológicos, sintáticos, semânticos e estilísticos dos discursos em Os Senhores, o que se dá na medida em que estes interferem no significado da obra como um todo, tanto nos aspectos de convergência como de afastamento entre os planos narrativos e as falas das personagens.

Neste capítulo, retomamos, ainda, o conceito de Mikhail Bakhtin referente ao cronotopo do limiar, o tempo/espaço da crise, que permeia as narrativas em Os Senhores, conferindo aos discursos do narrador e das personagens seu caráter peculiar.

A parte final do Capítulo III é dedicada ao estudo dos protogêneros em pormenor, a que fizemos menção em capítulos anteriores, a partir dos quais se desenvolveram diversos gêneros narrativos em prosa, que, chegando aos 
nossos dias, deixaram suas marcas na literatura ao longo do tempo, estando igualmente presentes em Os Senhores, de Gonçalo M. Tavares.

Por razões de escolha metodológica de desenvolvimento do trabalho, a partir do Capítulo I, e chegando às Considerações Finais, estabelecemos relações entre a obra Os Senhores e as obras de autores que têm se debruçado sobre os problemas e as características da vida no período da pósmodernidade, identificando possíveis conexões e pontos de aproximação, visando justificar seus comportamentos, posturas e falas a partir de referenciais do período no qual vivemos, parâmetros esses que situam as personagens como indivíduos da contemporaneidade, ainda que estejam localizadas em lugar e tempo inespecíficos.

O conjunto dos três capítulos busca, portanto, desvendar algumas das possíveis visões interpretativas da obra Os Senhores, de Gonçalo M. Tavares, tendo como base teórica as relações têmporo-espaciais sobre as quais se estabelece o constructo narrativo.

Faz-se necessário observar que, ainda que a obra ofereça muitas vertentes investigativas, este trabalho não trata das possíveis relações estilísticas e intertextuais entre as personagens e as personalidades da cultura que emprestam seus nomes aos livros, ficando em aberto, para futuros estudos, outros planos de investigação e pesquisa, entre os muitos que a obra de Gonçalo M. Tavares oferece aos pesquisadores da literatura.

Assim, a análise a que nos propomos neste trabalho tem como meta final chegar a tais níveis mais sutis de interpretação, tanto do enredo como das personagens, utilizando a porta dos cronotopos para a concretização dos vários planos de análise.

Vale acrescentar também que é desejo não apenas nosso, mas de muitos pesquisadores da literatura portuguesa contemporânea, aprofundar os estudos sobre este jovem autor, que desafia os limites da narrativa tradicional, pelo conteúdo e pela forma instigantes de sua obra, a qual se estende desde o romance e a poesia, passando pela dramaturgia, e chegando às narrativas curtas inovadoras, de que é constituída a obra Os Senhores, de autoria de Gonçalo M. Tavares, objeto desta tese. 


\section{PRESSUPOSTOS TEÓRICOS}

Tendo como substrato teórico fundamental a Teoria dos Cronotopos, formulada por Mikhail Bakhtin em sua obra Questões de literatura e de estética: a teoria do romance (1988), buscamos analisar as formas pelas quais se estruturam o enredo e os posicionamentos das personagens na obra Os Senhores, de Gonçalo M. Tavares, a partir do eixo têmporo-espacial, que funciona como determinante das tramas, das falas e dos comportamentos dos senhores.

A diegese se estabelece, portanto, a partir das várias conformações cronotópias, em que as grandezas de tempo e espaço se unem indissoluvelmente, de modo a determinar as relações dialógicas e a articulação das tramas nos vários planos narrativos.

Segundo a concepção de dialogismo, formulada igualmente pelo teórico russo, podem ainda ser apreciadas as relações de oposição e convergência que posicionam as vozes das personagens em embates segundo estatutos sociais e culturais.

Objetivando esta análise, quanto aos aspectos mencionados, utilizamos como referência outras obras do autor russo, que nos forneceram subsídios relevantes para a investigação do objeto de estudo, quais sejam, Problemas da Poética de Dostoiévski (2005), Estética da criação verbal (2003), A cultura popular na Idade Média e no Renascimento: o contexto de François Rabelais (2008), e Marxismo e filosofia da linguagem (1999), além de produções de outros autores, que têm investigado em profundidade as obras e os conceitos formulados por Mikhail Bakhtin, como é o caso de Beth Brait, Carlos Alberto Faraco, Augusto Ponzio, Katerina Clark and Michael Holquist Irene Machado, e outros.

Além da referida obra fundadora de Mikhail Bakhtin, sobre a Teoria dos Cronotopos, que utilizamos como referência essencial para a elaboração e a fundamentação teórica da proposta de trabalho da tese, outros autores nos forneceram subsídios relevantes para a investigação do objeto de estudo, como é o caso de Tzvetan Todorov, cujas obras Poética da prosa (2003), As 
estruturas narrativas (2004) e Introdução à literatura fantástica (2006), foram imensamente úteis como adjuvantes do processo investigativo.

Foram também de grande valia como subsídio a este estudo as obras dos teóricos franceses da Análise do Discurso, Patrick Charaudeau e Dominique Maingueneau.

Para efeito de estudo, partimos do pressuposto de que a respeito do conceito de heurística dentro da criação literária, há que se considerar aqui os elementos constitutivos das ciências humanas, entre os quais se inserem os conhecimentos de teoria literária, que não seguem, necessariamente, os pressupostos das chamadas ciências exatas e biológicas, para as quais é essencial a construção de teorias científicas nas quais hipóteses de confirmação ou de rejeição sejam o resultado de experimentos que garantam a sobrevivência ou não de concepções e descobertas. Diferentemente da ciência empírica, tal crivo de negação ou aceitação não sujeita as ciências humanas em todos os seus aspectos, não sendo este, certamente, o critério por excelência a sustentar a análise da criação literária como tal.

A heurística da criação literária parte da obra como constructo que se justifica de per si, e para o qual cabem análise e perquirição, sendo a obra a própria referência a partir da qual se podem eventualmente conectar os vários ramos da análise literária e as diferentes tendências investigativas que se estabeleceram no eixo diacrônico de desenvolvimento das teorias conhecidas.

A análise das falas em seus contextos, bem como dos discursos que articulam as interações Eu-Outro, uma vez firmado o conceito de tempo/espaço como eixo estrutural, permite atribuir significado ao dito e ao implícito ficcional, às vozes que nem sempre se revelam à primeira vista, aos elementos intrínsecos e constitutivos do discurso, às relações intertextuais, aspectos estes que estão imbricados nos vários planos narrativos, os quais permitem que a obra literária se estabeleça, primordialmente, como objeto artístico e cultural.

A investigação dá, ainda, ensejo a que elementos extralinguísticos, ligados a outros campos da cultura, que emergem a partir da investigação literária, e que, ultrapassando as dimensões do que é essencialmente pertinente à literatura, possam ser apreciados e analisados. 
Como complemento a esta análise, obras de diversos autores suplementam vários dos aspectos analisados, justificando e focando em pontos relevantes, que contribuíram sobremaneira para a sustentação teórica do trabalho. 


\section{CAPÍTULO I}

\section{TEMPO E ESPAÇO NO BAIRRO}

Sendo um dos objetos de estudo deste trabalho a questão dos cronotopos na obra Os Senhores, de Gonçalo M. Tavares, cabe aqui a referência teórica sobre a qual ela se baseia, que é a teoria estabelecida por Mikhail Bakhtin, em sua obra Questões de literatura e de estética: a teoria do romance (1988).

Em seus estudos de poética histórica, o autor renovou as acepções de tempo e espaço que, anteriormente na literatura, eram considerados dois processos distintos e tratados isoladamente em relação à assimilação da realidade pelo indivíduo histórico.

Tal reelaboração representou profundas implicações na visão artística dos processos assimilados da realidade, uma vez que o teórico russo propôs a fusão de dois conceitos, tempo e espaço, em um, a que chamou de cronotopo, termo advindo da matemática, com base na conceituação einsteiniana da Teoria da Relatividade, segundo a qual as grandezas de tempo e espaço estão unidas indissoluvelmente. Essa menção às ciências matemáticas só é relevante aqui em termos metafóricos, já que para Mikhail Bakhtin a ideia de cronotopo consiste em uma categoria aplicada especificamente à área da literatura, a qual reúne também, de modo indissolúvel, as mesmas grandezas, criando um conceito único, que no âmbito teórico é, simultaneamente, atinente tanto ao conteúdo quanto à forma. Para o autor,

No cronotopo artístico-literário ocorre a fusão dos indícios espaciais e temporais num todo compreensivo e concreto. Aqui o tempo condensa-se, comprime-se, torna-se artisticamente visível; o próprio espaço intensifica-se, penetra no movimento do tempo, do enredo e da história. Os índices do tempo transparecem no espaço, e o espaço reveste-se de sentido e é medido com o tempo. Esse cruzamento de séries e a fusão de sinais caracterizam o cronotopo artístico (BAKHTIN, 1988, p. 211, sublinhado nosso). 
O enfoque a partir dos cronotopos engloba a idéia de espacialização do tempo, isto é, a percepção do espaço como locus do desenvolvimento temporal das ações das personagens, tanto no eixo sincrônico como no diacrônico: tratase do aqui-agora que remete a outras sequências de aqui-agora, as quais comporão o desenrolar da trama. Ao mesmo tempo, pode-se falar também de uma temporalidade espacial, por meio da qual as duas grandezas juntas interferem nas ações, nas falas das personagens e nas suas interações com o ambiente, formando o que se poderia chamar de palco narrativo de experimentações, que, além de marcador temporal, funciona ainda como propiciador de encontros, de decisões que afetam a trama, de concretizações de atos, enfim, de reviravoltas no enredo.

Nada ocorre na narrativa fora desse enquadramento têmporo-espacial. As personagens são, estão e agem em função do quando-onde que as enforma, o que confere, simultaneamente, desenhos e contornos específicos aos sentidos narrativos. Vale ressaltar, contudo, que é o tempo o sinalizador e o condutor do fio narrativo, por ser a determinante que evidencia as mudanças no eixo temporal diacrônico.

Uma questão fundamental a conferir importância ao conceito bakhtiniano de cronotopo reside no fato de que os gêneros são determinados por ele, como igualmente são determinadas por tal conceito, não apenas a imagem do indivíduo, mas também a imagem da sua linguagem.

Segundo Irene Machado,

$\mathrm{Na}$ condição de pós-estruturalista, como o definiu David Lodge $^{3}$, M. Bakhtin entendeu o tempo na literatura como uma orientação formal e histórica. Contudo, sua concepção contrasta com as abordagens (sobre o tempo) apresentadas anteriormente. Para Bakhtin, existem elementos da estrutura interna que não são meramente composicionais, mas dimensionam aspectos históricos. Ou seja, toda referência espacial, onde se desenvolvem os episódios e por onde transitam os personagens, são instâncias temporais. [...]. Inicialmente, é preciso entender o cronotopo como um

\footnotetext{
${ }^{3}$ LODGE, David. After Bakhtin: essays on fiction and criticism. London and New York:
} Routledge, 1990. 
conjunto de possibilidades concretas [...] para exprimir a relação das pessoas com os eventos. [...]. Logo, o conceito de cronotopo se confunde com 0 conceito de narrativa (MACHADO, 1995, p. 246 e 248).

Outro importante ponto a observar é o de que a assimilação desta ideia nos vários gêneros romanescos se deu de modo complexo e intermitente no eixo diacrônico, o que resultou em aspectos temporais bastante variados do ponto de vista literário. Entretanto, é possível afirmar que foi o romance 0 gênero que se desenvolveu de forma mais estável e no qual é possível perceber, de maneira mais clara, a aplicação do conceito de cronotopo, tomando como base a evolução do romance europeu a partir do chamado "romance grego", ou "sofista", segundo o teórico russo (BAKHTIN, 1988, p. 213), e que será objeto de análise posteriormente neste trabalho.

No entanto, a aplicação da teoria dos cronotopos a partir do romance, segundo a proposição de Bakhtin, não exclui outros tipos de narrativa, como o conto, ou as narrativas do tipo das desenvolvidas por Gonçalo M. Tavares, objeto de estudo deste trabalho, que não se enquadram nem na tipologia do romance nem na do conto tradicional.

Vários são os cronotopos identificados pelo autor ao longo da história do desenvolvimento do romance, o que não implica considerar que seu crivo analítico percorre todas as tipificações cronotópicas possíveis, as quais, do ponto de vista taxonômico, representarão sempre um capítulo em aberto em termos de novas adições classificatórias, segundo o próprio autor:

[...] o estudo das relações espaciais e temporais nas obras de literatura só teve início há muito pouco tempo; além do mais, foram estudadas, sobretudo, as relações espaciais, as quais estão obrigatoriamente ligadas às temporais, isto é, não houve a abordagem cronotópica devida. $\mathrm{O}$ quanto esta abordagem 
proposta seja importante e fecunda, só poderá ser determinado no futuro pela evolução dos estudos literários ${ }^{4}$ (Idem, p. 362).

É aí que se pode inserir o primeiro questionamento deste trabalho no que diz respeito à obra de Gonçalo M. Tavares, cujas narrativas ensejam tipificações cronotópicas que se somam àquelas já identificadas por Bakhtin. Em termos da análise literária, as implicações e deduções extraídas da pesquisa da obra às vezes extrapolam a própria literatura, isto não significando que se deva deslocar o foco da análise ou distanciar-se do que a obra é capaz de falar por si mesma.

Pelo fato da obra do teórico russo ter sido escrita até o período que se pode denominar de modernidade, fazemos referência a alguns cronotopos como sendo adaptados ou modificados, quando são mencionados pela primeira vez, sendo, em seguida, usadas as denominações tais quais criadas por Mikhail Bakhtin. O cronotopo da estrada, por exemplo, hoje corresponde à rua. Do mesmo modo, outros cronotopos foram acrescentados àqueles já identificados por Bakhtin, reforçando a ideia do próprio autor, de que o estudo dos cronotopos deve ser dinâmico e evoluir à medida em que se desenvolvem os estudos literários.

Da mesma forma como surgem novas formas de falar sobre a literatura, também as novas narrativas suscitam, provocativamente, 0 aparecimento de abordagens que buscam dar conta dessas novas maneiras de narrar, especialmente no que diz respeito à cronotopia. Tal é o que sucede com a obra Os Senhores, de Gonçalo $M$. Tavares, em que a criação literária inovadora obriga um olhar analítico sob ângulos diversos.

Quanto ao fato de a teoria dos cronotopos bakhtiniana embasar a sustentação teórica do trabalho, vale lembrar que a cronotopia não apresenta apenas o tempo como condutor cronológico e sequencial do fio narrativo, ou o espaço como área física geograficamente localizada, mas de observar outras variantes cronotópicas que rompem com tal ortodoxia. Segundo Maingueneau,

\footnotetext{
${ }^{4}$ Este trecho faz parte das "Observações Finais", da obra Questões de literatura e de estética: a teoria do romance, capítulo escrito posteriormente por Mikhail Bakhtin, em 1973 (Nota da autora).
} 
[...] a Análise do Discurso prefere formular as instâncias de enunciação em termos de "lugares", visando a enfatizar a preeminência e a preexistência da topografia social sobre os falantes que aí vêm se inscrever. [...] Este primado do sistema de lugares é crucial a partir do momento em que raciocinamos em termos de formações discursivas; trata-se, então, segundo o preceito de Michel Foucault ${ }^{5}$, de determinar qual é a posição que pode e deve ocupar cada indivíduo para dela ser o sujeito. Isto equivale a dizer que a teoria do discurso não é uma teoria do sujeito antes que este enuncie, mas uma teoria da instância de enunciação que é, ao mesmo tempo e intrinsecamente, um efeito de enunciado (MAINGUENEAU, 1997, p. 32-33, grifo do autor, sublinhado nosso).

O efeito psicológico das cenas que compõem o enredo, os diferentes narradores, as falas e as ações das personagens, os modos pelos quais elas se caracterizam, e ainda, a forma como se distribuem os elementos de linguagem e de estilo, assim como os topoi a partir dos quais se desenvolvem as tramas, tudo isso está em relação direta com a espacialidade concomitantemente à temporalidade, grandezas segundo as quais, e de modo inseparável, se desenvolve o enredo propriamente dito.

O objetivo central do estudo dos cronotopos neste trabalho é demonstrar, portanto, os modos pelos quais se estruturam os enredos nas narrativas, tomando-se aqui a acepção de enredo em dois planos, isto é, o nível da fábula, ou o que se conta, e o nível do enredo propriamente dito, que consiste no modo como se conta, ou seja, a estruturação da fábula.

Segundo René Wellek e Austin Warren,

É preciso discorrer um pouco sobre a palavra "narrativa", que, quando aplicada à ficção, deve implicar o contraste da ficção representada, isto é, o drama. Uma história, ou fábula, pode ser representada por mimos ou pode ser narrada por uma única pessoa, que será o narrador épico, ou um dos seus

\footnotetext{
${ }^{5}$ FOUCAULT, M. A arqueologia do saber. Rio de Janeiro: Forense Universitária, 1986, p.
} 126.) 
sucessores. [...]. Mas o principal padrão da narrativa é a sua abrangência: ela entremeia cenas no diálogo (que poderiam ser representadas) com descrições sumárias do que está acontecendo (WELLEK; WARREN, 2003, p. 290, grifo do autor, sublinhado nosso).

Para os referidos autores, deve-se compreender o enredo como estrutura narrativa. Nesta acepção, ele "[...] é composto de estruturas narrativas menores (episódios, incidentes). As estruturas literárias maiores e mais abrangentes (a tragédia, a epopeia, o romance) desenvolveram-se historicamente a partir de formas anteriores e rudimentares como o chiste, 0 dito, a anedota, a carta; o enredo de uma peça ou romance é uma estrutura de estruturas" (Idem, p. 293).

Segundo Massaud Moisés, o enredo,

[...] correspondente ao inglês plot ${ }^{6}$, implica a ideia de causa $e$ efeito e diz respeito à disposição dos acontecimentos conforme a vontade do escritor: neste caso, o enredo confunde-se com a própria narrativa e não pode ser resumido. O enredo pressupõe um nexo de causalidade entre os acontecimentos (o leitor não pergunta: e depois?, como faz quando perante a história, mas: por quê?, e por isso depende de recursos narrativos, como o mistério, o suspense, o flashback, os intervalos, etc. [...]. [...] enquanto o enredo denota a totalidade das causas e efeitos que se organizam no curso da narrativa, a intriga parece a redução, ao essencial, dessa totalidade. A intriga constituiria o relato sucinto, abreviado, mas atento à noção de causalidade, dos eventos que se entrelaçam na direção de um fim. Seria sinônimo de "trama" (MOISÉS, 2004, p. 145, grifo do autor, sublinhado nosso).

O mesmo autor cita, ainda, a definição de fábula feita por Todorov, extraída a partir da teoria literária dos formalistas russos:

\footnotetext{
${ }^{6}$ plot: enredo. O enredo de um filme, romance ou peça é a história e a maneira pela qual ela se desenvolve (COLLINS Cobuild English language dictionary. London: HarperCollins Publishers, 1993, p. 1100). (Tradução livre da autora.)
} 
Segundo a doutrina literária dos formalistas russos, o vocábulo "fábula" encerra conotação específica, vizinha de "história", "enredo", etc.: a seu ver, a fábula consiste no "conjunto de acontecimentos ligados entre si e que nos são comunicados ao longo da obra", ou ainda, "conjunto de motivos em sua sequência cronológica e de causa e efeito" (TODOROV, 1965 apud MOISÉS, 2004, p. 184, grifo do autor, sublinhado nosso).

Quanto às personagens, há que se observar que, com variações específicas, cada uma apresenta peculiaridades que tornam difícil o almejado encontro com o Outro. O senhor Valéry, por exemplo, "[...] era pequenino, mas dava muitos saltos. Ele explicava: Sou igual às pessoas altas só que por menos tempo" (TAVARES, 2004a, p. 7).

Para esta personagem, a rua, o equivalente do cronotopo da estrada modificado, constitui o ambiente têmporo-espacial em que ela se vê confrontada com os demais passantes, tornando-se evidente, portanto, sua baixa estatura. É, pois, nessa circunstância, que o senhor Valéry age para compensar o que o incomoda, tomando como paradigma a altura dos demais transeuntes.

Este senhor, que tem medo de ladrões, desenvolve uma estratégia que ele julga protegê-lo do que mais teme:

O senhor Valéry tinha dois sacos pretos que não largava das mãos quando se encontrava na sua casa de duas assoalhadas. [...]. Antes do senhor Valéry sair de um compartimento da casa para outro, colocava todos os objectos existentes no compartimento num dos seus sacos pretos, passando depois para o outro espaço, já com o coração tranquilo. Quando voltava a entrar no compartimento inicial, abria o primeiro saco, com os objectos do outro compartimento, ali ficava, seguro numa das mãos. O senhor Valéry explicava: É por isso que tenho poucos objectos. Dá muito trabalho pô-los e tirá-los do saco. Quando o senhor Valéry saía de casa, levava os sacos com todos os objectos dos dois compartimentos, atravessava a 
rua, e ia depositá-los no cofre do Banco. O senhor Valéry explicava: É apenas uma precaução (Idem, p. 71-72).

Nesse caso, o senhor Valéry é presa do medo, colocando-se aí, ironicamente, o ambiente que se suporia ser o mais seguro de todos - a casa como o cronotopo do limiar, constituído por um tempo/espaço que deveria idealmente resguardar e proteger.

Assim, em outra instância, a insegurança desse senhor também se revela quanto à sua aparência, agindo ele no sentido de observar a reação do Outro, que é um paradigma externo, para saber se está feio ou bonito: "Se me sorriem percebo que estou bonito, se desviam os olhos percebo que estou feio. Teorizando, dizia ainda: A minha beleza é actualizada a cada instante pela cara dos outros" (Ibid., p. 49-50).

Outro tipo de cronotopo, o do encontro, envolve novamente o senhor Valéry e o seu animal de estimação. Aqui, o contato físico entre homem e animal não ocorre, e não por falta de desejo do dono, mas para evitar a dor da perda. Assim, o senhor Valéry mantém o seu pet, que não se sabe se é um cão, um gato, um pássaro, ou outro animal, permanentemente fechado dentro de uma caixa. E ele não o faz por indiferença ou falta de zelo, mas para evitar um sofrimento futuro: "O senhor Valéry explicava: É melhor evitar os afectos por animais domésticos, eles morrem muito, e depois é uma tristeza para o coração" (Ibid., p. 11).

É de notar que há, tanto por parte do senhor Juarroz como do senhor Valéry, total incapacidade para lidar não apenas com o Outro, mas também com as coisas práticas da vida, como usar uma ferramenta ou achar o próprio endereço. A dificuldade de comunicação das personagens com o Outro pode ser creditada ao medo do contato e do diálogo vivos, o que as leva a preferir o nível apenas do abstrato ou do idealizado para não ter de lidar com a vida e seus eventuais percalços.

Em "As três pessoas", revela-se a limitação comunicativa do senhor Valéry com o semelhante: "O senhor Valéry conhecia apenas duas pessoas. A pessoa que ele era, nesse exacto instante, e aquela que ele tinha sido, no 
passado. O senhor Valéry dizia: Se continuar a viver conhecerei uma terceira pessoa" (Ibid., p. 57). Desse modo, em seu horizonte só há espaço para o Outro que é ele mesmo no passado, no presente e, eventualmente, no futuro.

Em certa época, como "vendedor do interior das coisas" (p. 63), o senhor Valéry costumava entrar em confronto com os compradores, no que se configura igualmente como o cronotopo da sala de visitas. A explicação do narrador onisciente para o tipo de venda que faz o senhor Valéry é que ele não vende objetos, somente o seu interior.

Assim, diz o senhor Valéry: "Isto, por exemplo, é um prato. E desenhava. E o que eu vendo, é o interior do prato. E desenhava" (Ibid., p. 63-64). Ao ver o desenho e ouvir o que diz este senhor, as pessoas comentam: "Mas isso que desenhou é o exterior do prato[!]" (Ibid., p. 64). E o senhor Valéry contraargumenta: "[...] mas o que eu vendo não é o que se vê, é o interior. Eu sei que é mais fácil perceber o que é o interior num objecto oco - costumava dizer o senhor Valéry - mas por favor façam um esforço" (Ibid., p. 64).

Ao vender algo improvável, isto é, o interior das coisas, o senhor Valéry torna concreto o que não pode ser considerado isoladamente, mas que, dada a natureza fragmentada da personagem, ele vê como algo independente, e igualmente fragmentado, partes de algo que deveria ser visto como um todo, ou seja, o interior e o exterior de uma mesma coisa.

Em "A tristeza", revela-se uma das rotinas maníacas desse senhor, prisioneiro de rotinas inúteis, mas que lhe dão algum tipo de segurança:

O senhor Valéry percorria sempre as mesmas ruas da cidade com os mesmos sapatos, um par de sapatos para cada rua. Desde que nascera que vivia por ali, mas só conhecia 5 ruas que percorria com os seus 5 pares de sapatos diferentes (Ibid., p. 77).

O senhor Valéry, por ser costumeiramente distraído, às vezes confunde o chapéu com o cabelo. Assim, quando se esquece de colocar o chapéu, e já na rua, pensando estar usando o acessório, "[...] ao passar por uma senhora, tinha por costume levantar ligeiramente os cabelos à frente da testa, por 
cortesia. As senhoras sorriam muito, para dentro, com a distracção, mas agradeciam a gentileza" (Ibid., p. 13).

Às saídas diurnas para a rua o senhor Valéry prefere sair à noite, já que não gosta da sua sombra, a qual, segundo ele, constitui "[...] a pior parte de si próprio" (p. 73). Nas saídas noturnas, e pelo fato de as ruas não serem iluminadas, ele as percorre com uma pequena lanterna.

Quando os habitantes da cidade se preparavam para jantar e pela janela viam uma pequena luz avançando a passo certo, já sabiam que ali andava o senhor Valéry; e, por vezes, pela simpatia que aquela pequena obsessão provocava, abriam a janela e cumprimentavam-no [...]. Apesar do aspecto franzino do senhor Valéry, as pessoas sentiam-se mais seguras sabendo-o por ali, de noite, a percorrer as ruas com uma lanterna (Ibid., p. 74).

Aqui há uma inversão com a relação à questão da segurança, já que o medroso senhor Valéry, por sair à noite, o que se configuraria como temerário, consegue transmitir tranquilidade aos que estão em casa, e já sabem a quem pertence a lanterna, cuja luz se habituaram a ver.

Em O senhor Kraus (TAVARES, 2007b) há duas narrativas em dois planos distintos: uma delas mostra o próprio senhor Kraus, jornalista e escritor de crônicas satíricas, na rua, onde eventualmente encontra seus vizinhos e leitores, ou no Café, fazendo anotações para os seus artigos. A outra narrativa, dentro da primeira, exibe, em plena ação, as personagens das crônicas escritas pelo jornalista, que constituem os alvos da sua crítica, representados pelo Chefe, um político inepto e venal, e os seus Auxiliares, aduladores incondicionais do Chefe.

As crônicas passam a ser como que a ilustração da realidade na visão do jornalista, transcorrendo os eventos nos gabinetes e antessalas do poder, o que equivale ao cronotopo da sala de visitas, constituindo os bastidores recônditos da vida política, onde o Chefe e os seus Auxiliares protagonizam suas reprováveis falas, posturas e ações. Trancado em seu gabinete, o Chefe, que se tem alta conta, simula estar trabalhando. "Fechou a porta por dentro. 
Depois, sempre poderia dizer que estava numa reunião importante" (Idem, p. 14).

O tempo/espaço que se configura nas crônicas é o da vida política reprovável, que se passa longe dos olhos e do conhecimento dos eleitores, consistindo os gabinetes e salas adjacentes o palco das tramas e conluios, nos quais o ignorante e mal-intencionado Chefe, auxiliado pelos assessores, atenta contra o interesse público.

À semelhança do senhor Valéry, o Chefe preocupa-se com as aparências, só que em registro distinto. Para o primeiro, conta muito o aspecto físico, no caso, sua baixa estatura. Dando saltos na rua, ele age no sentido de se aproximar o mais possível de um ideal estético.

A preocupação do Chefe, por outro lado, tem a ver com a opinião pública, e apenas no que se refere às aparências do que ele simula fazer pelo povo: o importante para ele não é trabalhar em favor da população, mas aparentar que o faz, estando suas ações subordinadas às emulações dos atos que levam os outros a crer que ele ocupa seu tempo planejando e executando atos importantes no cumprimento do seu dever.

No caso do senhor Kraus, a sala de visitas se revela nas narrativas que constituem as crônicas escritas por ele ao jornal, em que as personagens do Chefe e dos Auxiliares estabelecem seus confrontos e decisões, indevidos e espúrios, nos gabinetes da vida pública, tempo/espaço do cronotopo em questão. Um destes embates ocorre quando da chegada dos Economistas ao gabinete do Chefe, marcada pelo susto e pela agitação dos assessores: "Os Auxiliares já estavam próximos. Corriam e gritavam assustados. Algo de grave acontecia. [...] Mas eles já estão ali, do lado de lá, a bater à porta do seu gabinete. "Os Economistas! Os Economistas estão a avançar!! - gritavam os Auxiliares ansiosos, do outro lado da porta" (Ibid., p. 15).

Como a fazer frente a um exército inimigo, já na antessala do gabinete do Chefe, surgem os Economistas, que, na instância imediata da chegada, configuram o cronotopo do limiar ou da "soleira", ou seja, o tempo/espaço da crise, segundo Bakhtin (1988, p. 354), que se evidencia diante do nervosismo do Chefe e dos Auxiliares. Para o teórico russo, o significado da palavra 
"soleira" adquire um significado metafórico, isto é, "[...] uniu-se ao momento da mudança da vida, da crise, da decisão que muda a existência (ou da indecisão, do medo de ultrapassar o limiar)" (Idem, p. 354).

A conversa do Chefe com os Auxiliares, já dentro do gabinete do Chefe, narra o encontro entre eles, mesclando três cronotopos: o do próprio encontro com os Economistas, o tenso clima do cronotopo da sala de visitas e a densidade do cronotopo do limiar: "Os Economistas dizem que é preciso cortar ainda mais nas despesas! - disseram de uma vez os Auxiliares, com respiração ofegante" (TAVARES, 2007b, p. 17). Esclarecido o Chefe pelos Auxiliares, sempre em processo de adulação, de que as despesas a serem cortadas são as dos Outros, o Chefe se sente aliviado. Contudo, os Auxiliares se apressam em explicar:

Sim, Chefe, mas tal não nos deve descansar. Porque os Economistas (e esta palavra era dita como se existisse receio de a repetir em voz alta) quando dizem que é urgente cortar as despesas dos outros não deixam de olhar para nós. E fixamente (Idem, p. 17).

No cronotopo da sala de visitas, a relação dos Auxiliares com o Chefe é, antes de tudo, de servilismo e adulação. Não há embate entre as duas partes, já que a vontade do primeiro na hierarquia prevalece, embora, muitas vezes, ele se impaciente com os assessores: "O Chefe estava já cansado de entrar em desespero com o auxílio daqueles homens. Tinha o direito de entrar em desespero sozinho, como um verdadeiro Chefe. Mas lá estavam eles de novo, os Auxiliares" (Ibid., p. 13).

A sala de visitas, no caso, é mais o tempo/espaço da convergência de ideias entre o Chefe e os Auxiliares do que da divergência em qualquer nível. Assim, o Chefe afirma peremptoriamente, sempre com a concordância dos Auxiliares: "[...] tudo o que não cabe dentro da televisão - [...] - não pertence ao país. Está fora do nosso território. Para ele o mapa mais real do país era o aparelho de televisão que tinha em casa" (Ibid., p. 49).

E o Chefe completa a sua estranha teoria: "O meu conceito de fronteira - repetiu o Chefe - é definido pelas linhas que delimitam o ecrã da televisão. 
Tudo o que surge fora do ecrã não pertence ao nosso país, está já para lá da fronteira. Estão a entender[?]" (Ibid., p. 51).

Diante dessa e de outras afirmações estapafúrdias, saídas com tanta certeza da boca do Chefe, "Um dos Auxiliares tomava apontamentos, enquanto o outro estava com a boca aberta, de espanto. Por vezes trocavam de funções" (Ibid., p. 51).

Tal espanto não é causado, todavia, pelo absurdo das afirmações, mas pela admiração incondicional dos Auxiliares em relação ao superior:

Os dois, no entanto, como que tremiam; um tremor, diga-se, não físico ou corporal. Pelo contrário: um tremor intelectual. Havia em ambos a sensação de que estavam a viver um momento único, o momento em que uma ideia sai para o mundo, pela primeira vez, com a força incontrolável de uma bomba (Ibid., p. 51).

O antagonismo só se dá com as esferas externas, como, por exemplo, os Economistas, que não partilham das ideias inusitadas do Chefe. Em "O índice (1)", entra certa vez no escritório do Chefe, aqui chamado de "aposentos centrais" (p. 110), uma grande comitiva de Economistas, encarregada de apresentar ao Chefe um relatório pormenorizado, contendo o resultado do trabalho de "mais de 32.000 Economistas" (p. 110): o diagnóstico do estado da economia do país, com mais de seiscentas páginas e um índice. É este último que atrai a atenção do Chefe: "Isto ajuda muito. Facilita a consulta - disse o Chefe, surpreendido" (Ibid., p. 110).

$\mathrm{Na}$ verdade, o Chefe não se preocupa, naquele momento, nem com o tamanho do relatório, nem com o diagnóstico sobre a economia do país. Apenas com o índice, foco de sua exclusiva atenção, como revela o narrador onisciente: "O Chefe estava fascinado. Aquela questão do índice. Que ideia! Estava bem rodeado, sem dúvida. Estes Economistas[!!]" (Ibid., p. 110). E ele não se cansa de externar sua admiração:

Aqui está! - murmurou o Chefe, mantendo o entusiasmo. Por exemplo, se eu estiver interessado no item: "pobreza generalizada”, vou aqui ao índice e cá está: página 322. É 
extraordinário! Pobreza generalizada: página 322. Que bonito[!] (Ibid., p. 111, grifo do autor).

Em dado momento, os Economistas começam a se impacientar com o encantamento do Chefe pelo índice e por seu total descaso pelo relatório. $O$ tempo/espaço da tensão da sala de visitas se acentua com a fala do Presidente da Comitiva dos Economistas, que "[...] cada vez mais impaciente, tentava controlar-se:

É apenas uma questão de organização. É um índice, nada de... Mas mais à frente apresentamos quatro propostas fundamentais para resolver o problema da pobreza no país. E ao mesmo tempo que falava, tentava, com as mãos, embora sempre delicadamente, forçar o Chefe a passar para o meio do relatório (Ibid., p. 112).

É possível observar aí o embate entre os interesses do Chefe e os dos Economistas, prevalecendo a visão superficial do primeiro: "As mãos do Chefe, no entanto, respondendo com um vigor inalterável, não deixavam. O Relatório continuava aberto no índice. Até ao final da sessão" (Ibid., p. 112-113).

Os atos espúrios do Chefe contra a população que o elegeu são tornados públicos e condenados no jornal apenas por meio da visão do jornalista, na medida em que aparecem por meio das crônicas satíricas. $O$ senhor Kraus é, assim, conforme explica Bakhtin, "o terceiro", aquele que tem a visão do homem público:

A vida pública, como qualquer acontecimento que tenha algum sentido social, dirige-se ao público, pressupõe obrigatoriamente um espectador, um juiz, um avaliador; para ele sempre há lugar no acontecimento, ele é seu participante obrigatório (indispensável). $\underline{O}$ homem público sempre vive e age no mundo, cada momento de sua vida, por essência e por princípio, admite ser conhecido por todos. A vida pública e 0 homem público são por natureza abertos, visíveis, audíveis. A vida pública possui formas variadíssimas de autopromoção e de auto-avaliação (inclusive na literatura). É por isso que aqui 
absolutamente não surgem problemas relativos à colocação de um observador e ouvinte dessa vida (um terceiro) e relativos às formas particulares da sua exteriorização (BAKHTIN, 1988, p. 244, grifo do autor, sublinhado nosso).

As crônicas do senhor Kraus (TAVARES, 2007b) também expõem a dificuldade nas relações entre o povo e os políticos. Não há coincidência de objetivos entre as ações do governante, no caso, o Chefe, e as aspirações do povo. Os encontros do Chefe com os técnicos, que se dão no cronotopo da sala de visitas, representado pelo gabinete do Chefe, figurativizam o temor do primeiro de ter de agir, de demonstrar que trabalha de alguma maneira em favor do povo.

No caso do senhor Kraus, ele é o observador e avaliador, cuja função profissional como jornalista e cronista é expor satiricamente o que julga ilícito ou reprovável por parte dos políticos, para que o povo tome conhecimento e reaja aos desmandos daqueles que o representam. Tal exposição aparece na crônica "Decisões legais, e outras (1)", com forte dose de ironia, em que o Chefe, diante dos protestos populares, tenta criar uma lei que não prejudique ninguém, em outras palavras, uma lei que agrade a todos sem exceção:

Sendo eu um ser humano, qualquer lei aprovada que prejudique um único homem é uma lei que me persegue individualmente. Pelo menos desta maneira a considero. Foi assim que falou o solidário Chefe, que era muito agarrado à população - tanto mais que se tornara urgente acabar com os protestos constantes que começavam a surgir depois de qualquer alteração da lei (Idem, p. 87).

A reação dos Auxiliares consiste no fato de que o anseio do Chefe representa uma total impossibilidade na visão dos assessores: "Isso que nos pede não é uma lei, Chefe, é um milagre - disseram os auxiliares" (Ibid., p. 87). Indecisos quanto ao caminho a seguir, e ansiosos por agradar ao Chefe, um dos Auxiliares finalmente sugere a criação de uma seção que seja responsável pelos milagres, já que no governo não há nenhum departamento que se especialize nesta área, sugestão que é imediatamente aprovada pelo Chefe. 
Uma dúvida, então, assalta o Chefe após o entusiasmo inicial: "[...] pelo seu rosto de imediato se notou que a solução encontrada lhe levantava novas e profundas questões: haveria ainda, na folha A4 do organograma, espaço para mais um departamento[?]" (Ibid., p. 88).

A rotina profissional do senhor Kraus consiste no exercício do seu ofício de jornalista e, por decorrência, nas denúncias políticas que faz por meio de suas crônicas, cujas personagens seguem o ritual repetitivo de usar de artimanhas e engodos para enganar os eleitores. Assim, no Café, o senhor Kraus faz anotações usando recursos de analogia:

No dia seguinte às eleições, no Café, na mesa do costume, o senhor Kraus apontou no seu caderno: Observação a posteriori (1). No contato com a população mais simples, alguns políticos dão beijos na cara como quem do cais diz adeus ao barco que parte para nunca mais voltar (Ibid., p. 65, grifo do autor).

Os atos políticos que o senhor Kraus busca denunciar em seus artigos e crônicas reflete, de modo contundente e irônico, o cotidiano rotineiro dos malfeitos executados pelos representantes do povo, em um suceder ininterrupto de ações deletérias. Usando da ironia própria das sátiras e paródias, o jornalista constrói uma metáfora, de modo a denunciar a extensão dos danos causados pelos políticos às camadas mais indefesas da população:

Do outro lado, homens seguindo as ordens do Chefe disparam em direção aos pássaros mais lentos - disse o senhor Kraus. Deste lado, o Chefe recolhe um ou dois pássaros feridos e, à vista de todos, trata de recuperá-los, com entrega, dedicandose, dia após dia, em exclusivo, à sua recuperação. Salvar, pelo menos um dos pássaros, passará a constituir uma obsessão. Um homem ingênuo poderá pensar que seria mais fácil não ter dado primeiro ordens para disparar sobre os pássaros. No entanto, no ano seguinte o processo será repetido (Ibid., p. 45).

Nessa crônica, os pássaros lentos são representativos dos estratos mais desfavorecidos da sociedade, sofrendo, por conseguinte, os maiores prejuízos, causados por medidas e leis perpetradas pelo governo, que em nada os 
favorecem. Como pássaros abatidos, boa parte da população fica entregue à própria sorte. No entanto, e apenas para efeito de marketing político, diante de tantos "pássaros mortos", o Chefe "se esforça", com falsa dedicação, para salvar um ou dois, quando na verdade, poderia tê-los salvado todos, se tomasse as medidas necessárias para Ihes garantir a vida. $O$ fato é que grande parte da classe política continuará, como o Chefe, a dar ordens para que outros pássaros sejam abatidos, em um processo indefinidamente repetido ano após ano.

De modo análogo, a crítica do senhor Kraus também se dirige aos eleitores por suas escolhas ruins:

As eleições haviam terminado e o varredor há mais de duas horas que com a vassoura empurrava os boletins de voto para o canto da sala. Os boletins, agora inúteis, avançavam contra a vontade, para o canto, como se fossem guardanapos sujos e não papéis determinantes para um certo país numa certa altura (Ibid., p. 64).

Assim, o senhor Kraus, cronista e satirista, busca o Outro na forma do público leitor dos seus artigos. Trata-se de seu meio de comunicação e de aproximação com o Outro, indistinto, distanciado e anônimo, que ele busca informar e conscientizar politicamente. Quando Ihe fazem perguntas na rua, o senhor Kraus responde, sempre investido da figura do jornalista, que ele não deixa de ser em nenhum momento, mesmo quando está sentado no Café, na mesa habitual, fazendo anotações para suas crônicas (p. 65).

Por meio de suas personagens, isto é, o Chefe e os seus Auxiliares, o senhor Kraus busca criticar a corrupção e os desmandos políticos daqueles que exercem o poder, e sempre se colocam frontalmente contra as necessidades e desejos da população. Seu outro objetivo é o de conscientizar o povo sobre as formas ilícitas de ação desses mesmos políticos, ao reproduzir, nas crônicas, o que se passa na realidade, prestando ao Outro, portanto, um importante serviço.

Seus contatos reais com a alteridade, os leitores das suas crônicas, que ocorrem eventualmente na rua, são passageiros e superficiais: "Já comecei a 
ler as suas crônicas, senhor Kraus. O mundo anda agradável, não? O senhor Kraus sorriu. Agradeceu. Despediu-se" (Ibid., p. 23). O comentário do leitor é revelador do grau de alienação de muitos como ele.

No capítulo "O Chefe que gostava de movimento (2)", o político simula estar fazendo algo de útil, juntamente com os seus dois Auxiliares, quando então, obriga seus assessores a se movimentarem mecanicamente, instandoos a bater os pés no chão ininterruptamente. Na verdade, para o Chefe, o mais importante não é ser, mas aparentar. Ele justifica tal ação, que denomina de "propriedade comutativa da linguagem" (p. 24):

Tal como dois mais três é igual a três mais dois, não gostar de estar parado é igual a gostar de movimento. E mais: gostar do movimento é igual a não gostar de estar parado. Não sei se me entenderam? [...]. É esse o problema. Precisamos de fazer coisas. Não podemos estar parados. [...]. Pois bem. Os dois, agora, mantendo-se sentados, vão bater com os pés no chão, muitas vezes, até eu mandar parar. Não param até as eleições[!] (Ibid., p. 24-25).

Durante toda a narrativa, nunca se dá, na prática, o tempo/espaço do encontro entre o Chefe e a população por ele governada, como se pode observar pela pergunta de um dos Auxiliares: "[...] o Chefe já alguma vez veio a esta terra tão desagradável, friorenta, deserta, nojenta até, sob certo ponto de vista, mas tão prometedora[?]" (Ibid., p. 39). A resposta do Chefe revela o desgosto que sente pela ideia desse eventual encontro, e a repulsa que tem em relação ao Outro, ou seja, o povo: "Eu? Claro que não. Você é louco[?]" (Ibid., p. 39).

O Outro com o qual o Chefe gosta de se relacionar é representado apenas pelos Auxiliares, no tempo/espaço reservado do gabinete/sala de visitas. Este é o seu espaço natural, onde ele é adulado pelos assessores ininterruptamente, os quais the fazem as vontades, dando-Ihe também ideias para a sua autopromoção junto ao povo, especialmente na época das eleições.

Quando o Chefe é reeleito para um segundo mandato, é imensa a alegria dos Auxiliares pelo reencontro: "Em silêncio, um dos Auxiliares, 
sentindo o seu coração bater ao ritmo das antigas caçadas a índios, murmurara mesmo, para si próprio: nem pareço um homem civilizado! Estava comovido. $\mathrm{O}$ Chefe regressou; o Chefe, o Chefe, o Chefe regressou[!]" (Ibid., p. 75-76).

Em O senhor Calvino (TAVARES, 2007c), ocorre igualmente o cronotopo da sala de visitas, tempo/espaço do embate e da tensão. Certa vez, após terminarem de jogar, o senhor Calvino e o senhor Duchamp iniciam uma discussão em torno da elaboração das regras do jogo a posteriori para saber quem é o vencedor. Assim, "Começaram então, em alternância, a formular regras para o jogo que já haviam jogado, cada um tentando definir o jogo capaz de o fazer, embora a posteriori, vencedor" (Idem, p. 31, grifo do autor). Tal discussão expõe o confronto próprio desse cronotopo, que, na série Os Senhores, adquire características aparentemente despropositadas e "ilógicas", como se fosse possível estabelecer regras para um jogo após o seu término. A vida desse senhor consiste em um continuum rotineiro e monótono, ainda que surpreendente, do ponto de vista de seu comportamento e reações. É o que se pode observar em "A colher":

Para treinar os músculos da paciência o senhor Calvino colocava uma colher de café, pequenina, ao lado de uma pá gigante, [...]. A seguir, impunha a si próprio um objetivo inegociável: um monte de terra (cinquenta quilos de mundo) para ser transportado do ponto A para 0 ponto $B$ - pontos colocados a quinze metros de distância um do outro. [...]. E Calvino utilizava a minúscula colher de café para executar a tarefa [...], segurando-a com todos os músculos disponíveis. [...]. Paciente, cumprindo a tarefa, sem desistir ou utilizar a pá, Calvino sentia estar a aprender várias coisas grandes com uma pequenina colher (Ibid., p. 45, sublinhado nosso).

Como um mestre budista, o paciente e disciplinado senhor Calvino se dedica a tarefas pouco usuais no sentido de aperfeiçoar o seu modo de ser. Ele, mais do que a maioria dos senhores, tem uma autoconsciência que o impele a fazer coisas cujo significado transcende o que de imediato pode aparentar, especialmente em termos de solidariedade. 
O não encontro é, de fato, a rotina real e emocional dos senhores, que tentam preencher suas vidas com atividades que Ihes suprem, em parte, conscientemente ou não, as carências afetivas. São homens solitários, cujas idiossincrasias emergem pública e privadamente. No caso do senhor Calvino, tal fato se evidencia quando ele se oferece para levar a passear o cão cego de um vizinho, invertendo a questão do cão guiar o cego:

É simples e rápido de contar: o cão de um vizinho, mais precisamente do senhor D., cegou. Uma doença e a idade. $\mathrm{O}$ cão sempre vivera e passeara por ali, pelas redondezas, pelo meio dos sons, dos cheiros, daquele ar. O senhor Calvino ofereceu-se. Ao fim do dia ia buscar o cão cego e levava-o, de coleira, a passear pela cidade (Ibid., p. 51).

Em Tavares, os encontros idealizados se dão com maior frequência que os reais, como descritos na teoria dos cronotopos bakhtiniana. Nas narrativas dos senhores, a desejada aproximação do indivíduo consigo mesmo e também com o Outro, na falta de realização palpável, busca achar elementos de substituição.

Desse modo, as personagens tentam suprir seus anseios por meio de animais de estimação, como ocorre com os senhores Valéry e Calvino. Em outras ocasiões, é um objeto que cumpre o papel afetivo de substituir a companhia desejada, preenchendo, assim, o seu vazio existencial. O senhor Calvino, por exemplo, arranja, certo dia, um balão bem cheio, que ele leva a todos os lugares, desdobrando-se em cuidados em vista da fragilidade do objeto, como se dedicasse tão amorosa atenção à pessoa amada:

Nos transportes públicos, em horas de grande concentração de pessoas, o senhor Calvino levantava o balão acima da cabeça e com esforço mantinha, em todo o percurso, o braço bem levantado para que um movimento mais descuidado não o rebentasse. Em casa, antes de dormir, colocava o balão junto à mesa-de-cabeceira e só depois, sim, adormecia (Ibid., p. 16, sublinhado nosso). 
O próprio senhor Calvino, em outra circunstância, constitui a prova da necessidade do encontro afetivo entre homem solitário e animal. Ele pode ser observado alimentando, como fazia todas as manhãs, o seu bicho de estimação - um gato - cujo nome é Poema:

Ao fim do dia, depois de terminadas as tarefas urgentes, $\underline{0}$ senhor Calvino acariciava-lhe o pelo com a delicadeza e a hábil distração aparente dos tocadores de harpa. Naqueles instantes, o universo abrandava as rotaç̃os ganhando a lentidão inteligente dos pequenos felinos (Ibid., p. 25, sublinhado nosso).

Fica aparente, no que se refere aos animais de estimação dos senhores Calvino e Valéry, o que se estende, de modo geral, às outras personagens da série Os Senhores, que é a mencionada dificuldade de estabelecerem vínculos afetivos incondicionais. Sob a escusa da futura dor da perda, revelamse o mascaramento da incapacidade de relacionar-se, de conviver, mesmo com um animal, como também a impossibilidade de assumir as consequências advindas desses relacionamentos, quer nas suas partes agradáveis quer nas ruins.

O cronotopo da sala de visitas, sendo o tempo/espaço da tensão, dá ensejo a um confronto entre o senhor Calvino e o seu gato, Poema. Neste caso, a cozinha do senhor Calvino se constitui na sala de visitas, na qual se confrontam homem e felino. O bichano, além de devorador de todos os tipos de alimento, também se opõe ao dono na hora do banho: "Dar banho ao Poema não era fácil; ele como que resistia à limpeza, exigindo de modo saltitante uma liberdade impudica que só a sujidade permite" (Ibid., p. 25).

A difícil relação com o Poema - o gato - metaforiza a igualmente difícil compreensão do que significam a poesia e a literatura para o homem contemporâneo. Ao alimentar-se de tudo, o gato estabelece outra metáfora com relação à poesia, que se "alimenta" das vivências, visões e questionamentos humanos. Tudo pode ser alimento para a poesia. E em um processo antropofágico, dela se alimenta, por sua vez, o homem. 
É de ressaltar, ainda, a correlação entre o nome do gato, Poema, e a questão autoral do poeta, que encontra dificuldades em sua lida com a obra em construção, do mesmo modo que o manejo do gato não é fácil. Assim como um gato não se submete facilmente ao seu dono, também a poesia não pode ser "domesticada" pelo poeta, logrando ter os versos, segundo a metáfora proposta, uma boa porção de insubmissão em relação ao seu autor.

O relacionamento com o Poema metaforiza, desse modo, a dificuldade humana em perceber a complexidade da arte e da poesia e tudo o que a isto se relaciona.

Na metáfora, a perda do Poema, que um dia cai da janela, leva o senhor Calvino a substitui-lo por outro animal, também chamado Poema, fato que remete à continuação da lida complexa com temas igualmente difíceis, como a arte e a poesia, o que se estende também às relações afetivas, retomando a ideia expressa pelo senhor Breton (TAVARES, 2009, p. 13), de que a aprendizagem de um verso pode estar algumas vezes fora de sincronia com a aprendizagem do sofrimento.

Medicar o Poema, quando necessário, é também uma tarefa impossível para o senhor Calvino. Nesta circunstância, o embate entre homem e animal se acentua: "Mas bem pior ainda era dar ao bicho uma injeção. Era a única altura em que as garras eram dirigidas a Calvino. Aquele animal preferia adoecer, a ser medicado" (TAVARES, 2007c, p. 25).

Aqui a medicação representa os possíveis e eventuais remendos que algum poeta despreparado possa, porventura, tentar fazer em seus versos, aos quais eles resistirão bravamente, como o Poema, o gato, frente às investidas bem-intencionadas do senhor Calvino.

Nessa narrativa, fica claro 0 preenchimento afetivo cumprido pelo animal, configurando novamente o cronotopo do encontro. A rapidez com que Calvino, diante da morte do primeiro bichano, o substitui, não deve ser interpretada, todavia, como um descaso por parte do dono, que, ao perder seu pet, imediata e casualmente arruma outro, como quem compra uma roupa nova para pôr no lugar da velha. 
Para seres carentes de afeição e de contato como o senhor Calvino, a pior hipótese seria a solução de continuidade que se interporia entre o convívio afetuoso com o bicho e a dor da perda sentida durante mais tempo, a qual se prolongaria até a chegada eventual de outro animal.

O segundo Poema, substituto do primeiro, tem mantido o nome, de natureza lírica e delicada, capaz de suscitar associações elevadas com a arte literária, criando assim, pelo imediato preenchimento, uma marca de não substituição, em que a rápida troca sinaliza um continuum afetivo permanente e confortador.

Da parte desse senhor, praticamente inexistem relações com a alteridade, o semelhante, além daquelas eventuais e passageiras, que ocorrem na rua. Como solução parcial, ele vai encontrando objetos de substituição no plano relacional e afetivo, como o balão, objeto de seu carinho e atenção como se fosse um ser vivo (p. 15-16); ou da "janela de abotoar" da sua casa (p. 19), além do Poema. Na verdade, o senhor Calvino vive um solipsismo quase absoluto devido às suas características intrínsecas, sendo constante a sua preocupação e os seus cuidados com o Outro, sejam animais, objetos, ou pessoas.

Isto se manifesta em uma ocasião, no capítulo "O sol", quando Calvino, ao observar seus livros na prateleira, nota o desbotamento causado nas capas pelo efeito da luz solar: "Olhou para os outros livros na prateleira. Todos estavam a perder a sua cor original, como se a luz do sol mastigasse ou roesse - sim, aquilo parecia o trabalho de um roedor sutil - a capa dos livros" (Idem, p. 47).

Novamente, ocorre neste episódio um processo de antropomorfização, ao conferir o senhor Calvino ao sol, "vontade", "músculos frágeis" e o desejo de ler:

[...] o sol queria abrir os livros, a sua luz concentrava-se, com toda a potência, na capa de um livro porque o queria abrir, queria entrar na primeira página, ler as narrativas, refletir a partir das grandes frases, emocionar-se com os poemas. O sol queria simplesmente ler, ambicionava-o como a criança que está prestes a entrar na escola (Ibid., p. 48). 
Prosseguindo em seu raciocínio, a personagem decide agir, em retribuição, "[...] esse toque carinhoso que em certos dias a luz do sol projeta no rosto do homem, tranquilamente, mas como que o salvando de uma grande tragédia, do desespero, por vezes mesmo do suicídio" (Ibid., p. 48). Tal contrapartida vem na forma cuidadosa da escolha apropriada de um título:

Estava a escolher um livro para alguém ler. Com atenção profunda escolhia o livro mais apropriado; não estava, reparese, a escolher de acordo com o seu gosto, mas sim de acordo com o gosto do outro. [...]. [...] e pousou o livro, assim, aberto no início da narrativa, virado para o ponto por onde o sol costumava descer (Ibid., p. 48-49, sublinhado nosso).

A escolha do senhor Calvino recai sobre a obra Alice no país das maravilhas, de Lewis Carroll', aberta na primeira página: "('Alice começava a ficar mais que farta de estar para ali sentada ao lado da irmã, na margem do rio, sem nada para fazer.'). Amanhã, voltaria de novo para virar a página. E nos dias seguintes faria o mesmo até ao final do volume" (Ibid., p. 49, grifo do autor).

Em outra instância, na rua, o senhor Calvino cruza com um casal de namorados. Ao observá-los, nota que o casal "[...] entre mordiscar lábios e murmurar palavras a menos de um centímetro se divertia naquele espaço minúsculo entre eles, onde alguém teria, por certo, construído um parque de diversões, invisível aos olhos dos outros" (Ibid., p. 58).

Tal observação, por parte do senhor Calvino, revela não apenas curiosidade, mas o anseio pela aproximação dele próprio em relação a uma realidade que não the pertence, e que, todavia, Ihe permite imaginar que se trata de algo agradável.

7 Charles Lutwidge Dodgson (1832-1898), mais conhecido por seu pseudônimo, Lewis Carroll, foi um autor inglês, matemático, diácono anglicano e fotógrafo. Sua obra mais importante é Alice no País das Maravilhas (Alice's Adventures in Wonderland), escrito em 1865. Trata-se de um autor notável por sua habilidade no gênero que escolheu para escrever tanto prosa como poesia, que é o gênero denominado, em inglês, de nonsense (COLLINGWOOD, Stuart. The life and letters of Lewis Carroll. London: T. Fisher, p. 8). (Tradução livre da autora) 
Como rotina, aos sábados de manhã, o senhor Calvino atravessa $O$ Bairro, de um lado ao outro, portando, na mão direita, uma vara metálica absolutamente paralela ao solo. Na volta, ele troca a vara para a mão esquerda. Desta vez, o braço e a vara balançam livremente. Às pessoas curiosas com relação à mudança, "Calvino explicara-o logo nas primeiras vezes, por isso já ninguém se espantava com a mudança abrupta" (Ibid., p. 30). A alternância de movimentos, diferente na ida e na volta, denota a tentativa, por parte do deslocado senhor Calvino, da busca por equilíbrio.

Em se tratando do senhor Walser (TAVARES, 2008), que mora em uma área de floresta natural - tempo/espaço bucólico e propício ao idílio -, afastado dos edifícios onde vivem os demais senhores, há razões específicas e não casuais que o levaram à escolha deste ponto distante. Torna-se aqui mais clara a ideia de aproximação em direção ao Outro, ainda que em potencial, já que a casa, segundo o desejo do seu dono, representa o primeiro passo para um futuro encontro.

Assim, descreve o narrador onisciente, expressando o monólogo interior da personagem:

Como o senhor Walser está contente! No meio de arbustos, ervas selvagens e outras manifestações da natureza ainda em pleno e imprevisível trajeto de vida, eis que foi possível construir - por via de um sentido técnico especializado de que só a grande civilização é capaz - a casa simples, sem nada de luxuoso ou ostensivo, uma mera casa para viver, a de Walser, homem que se encontra, por enquanto, sozinho no mundo, mas que vê naquela construção finalmente terminada quantos anos demorou?! tantos! - uma oportunidade para no fundo, sejamos sinceros, encontrar companhia (Idem, 2008, p. 11, sublinhado nosso).

Para a personagem, a diferença entre a realidade urbana e a natureza onde escolhe morar, envolve uma distância que "[...] não deve ser medida em centímetros de passada, mas em séculos, talvez milênios" (Ibid., p. 15). 
Configura-se aqui a impregnação cronotópica a que se refere Bakhtin (1988, p. 349), em que toda a atmosfera de sentimentos descrita pelo narrador onisciente engloba de modo inseparável tempo e espaço: para o senhor Walser, poucos passos separam a natureza selvagem da sua casa, mas séculos, ou até milênios marcam, segundo ele, a separação da natureza intocada pelo homem das conquistas humanas, com todo o progresso tecnológico ocorrido ao longo do tempo, o que permitiu a ele a conquista do seu sonho: o conforto da modernidade, representado pela casa, em meio ao espaço bucólico da floresta.

Outro aspecto importante diz respeito à simbologia do cronotopo da estrada, segundo o teórico russo (Idem, p. 350), representado pela via estreita que conduz, pelo meio da floresta, à casa do senhor Walser. A estrada não leva apenas à casa em si, como também à mudança de vida da personagem, à realização dos seus ideais, ao cronotopo do encontro em potencial. Do elemento concreto, a estrada, chega-se à metáfora da estrada como a própria vida, com todas as venturas e percalços que podem ocorrer ao longo dela.

Segundo Bakhtin,

Este (a estrada) é o ponto do enlace e o lugar onde se realizam os acontecimentos. Parece que o tempo se derrama no espaco e flui por ele (formando os caminhos); daí a tão rica metaforização do caminho-estrada: "o caminho da vida", "ingressar numa nova estrada", "o caminho histórico", e etc.; a metaforização do caminho é variada e muito planejada, mas o sustentáculo principal é o transcurso do tempo (Ibid., p. 350, grifo do autor, sublinhado nosso).

Em realidade, a narrativa do senhor Walser constitui um verdadeiro quest ${ }^{8}$, que envolve a tomada de uma série de decisões em direção ao objetivo

\footnotetext{
${ }^{8}$ quest: s. busca. Palavra arcaica ou de uso literário. Uma aventura que se dá durante uma busca representa uma longa e difícil procura por algo de valor especial (COLLINS Cobuild English language dictionary. London: HarperCollins Publishers, 1993, p. 1177). (Tradução livre da autora.)

quest: $s$. busca, procura; expedição, jornada. -in quest of: em demanda de, em busca de. (The new BARSA DICTIONARY of the English and Portuguese languages. Appleton-CenturyCrofts. New York: Meredith Publishing Company, 1964, v.1, p. 445).
} 
maior da personagem: a mudança para um ponto afastado da região urbana, o desejo de aproximação com a natureza, o anseio por um lugar onde possa receber seus amigos para conversar, e, futuramente, quem sabe, realizar o sonho de encontrar uma companheira com quem compartilhar a vida.

Para a realização de tal empreendimento, além de tomar decisões, ele teve de planejar a sua casa dos sonhos, construí-la, lutar para manter limpa a pequena estrada que dá acesso a ela, e, uma vez pronta a morada, ficar, em dado momento, a ponto de desfrutá-la: "De fato, não construíra aquela casa para o homem solitário que era naquele momento. Sejamos claros, sem entrar em pormenores: Walser tinha grandes expectativas" (TAVARES, 2008, p. 17).

A partir daí, todavia, este senhor enfrenta a desventura de saber que seu sonho começa a ser desfeito pelas múltiplas intervenções dos profissionais da construção, os quais vêm reparar os malfeitos havidos durante a obra.

A primeira parte, a do sonho que se torna realidade, e que se materializa ao término da construção, enche de felicidade a personagem:

$\underline{\text { Se até ali a ausência de um espaço confortável, fechado, }}$ unicamente seu, fora um obstáculo intransponível para a execução prática de alguns convites que estavam bem ali, há vários anos, na sua cabeça, como que já escritos ou verbalizados, agora, ainda com o ostensivo cheiro a novo que vinha das madeiras, da pintura das paredes, do próprio ruído das máquinas necessárias à sua vida doméstica de homem sem companhia, mas que ainda assim, está claro de ver, se alimenta e suja as coisas, agora, então, com a nova casa, tudo lhe parecia possível (Idem, p. 11, sublinhado nosso).

A expectativa, e tudo o que vem por acréscimo a ela, é o conjunto de elementos subjetivos que complementam a parte material, sobre a qual não se tem controle. Escapa ao senhor Walser o imponderável, o desvio, algo que ligado à parte física como dado concreto, no caso, o surgimento dos profissionais, e que acaba por tornar-se o impedimento que rasura o sonho.

De modo análogo, coloca-se para o senhor Walser, como fator contrário às suas expectativas, o seu modo romântico e idealizado de ser em relação a 
um mundo objetivamente constituído, um tempo/espaço que estimula a construção de sonhos, e, ao mesmo tempo, se encarrega de destruí-los, o que é típico da sociedade contemporânea, fundada sobre o consumo e o descarte de bens, colocando em cheque a própria qualidade desses bens.

Ainda que ingênuo, é de salientar que, de todos os senhores da série, ele é o que tem, de forma consciente, não apenas a busca pelo encontro com o Outro, mas toma as medidas necessárias - a construção da casa - para propiciar a realização do desejo. Todavia, o encontro que se configura real é o que se dá com os especialistas dos reparos, o que acaba por representar o oposto do seu anseio, pela desmontagem do ideal por tanto tempo acalentado: a desfiguração da casa, a qual, aos poucos, se desfaz diante da quantidade de consertos, assim como o adiamento compulsório da possibilidade de encontrar companhia.

Em O senhor Walser, a busca do Outro se dá pela tentativa de exercer controle sobre a concretude: a floresta, a estrada, a casa, os planos futuros cuidadosamente projetados, os detalhes físicos da casa, a carta-convite escrita a Thereza M., permitindo que vários cronotopos se superponham em uma dada circunstância narrativa. De fato, os cronotopos não existem isoladamente, podendo coexistir, em muitos casos, como ocorre com os cronotopos da estrada e do encontro, ou em outros, os quais, além dos dois cronotopos mencionados, se junta o da sala de visitas.

Para Bakhtin (1988, p. 223-224), os cronotopos da estrada e do encontro, em conjunção, podem marcar ocorrências fortuitas ou não, mas, de todo modo, tais encontros configuram uma mudança no sentido da narrativa, para o bem ou para o mal, ou seja, o curso narrativo sofrerá transformação em vista do encontro que se deu, diferentemente do que ocorre, algumas vezes, com os senhores. Segundo o autor russo, "[...] é concebível por todos a importância dos encontros (que às vezes determinam diretamente todo o destino de um indivíduo) na vida e na rotina cotidiana de cada pessoa".

No caso do senhor Walser, o cronotopo do encontro em potencial, constituído por uma mescla ideal de natureza e conforto urbano, tal mudança de destino ocorre. Para ele, tudo se esvai rapidamente diante dos olhos, sendo ambos os desmanches, o da casa e o do sonho, colocados em oposição 
temporal em relação à duração de cada um. Assim, o longo tempo de espera para entrar na posse da casa se opõe ao curso de apenas um dia - tempo necessário aos profissionais para desmontar as partes defeituosas, do telhado ao rodapé, mudando de lugar até mesmo as paredes.

Ao longo de toda a tarde, vários profissionais foram chegando [...]. Quanto à casa, aos poucos começava a ficar irreconhecível pois os problemas pareciam ser maiores do que ao início se suspeitara. Duas janelas estavam já desmontadas e substituídas provisoriamente por cartão, fixo às paredes com fita-cola forte (TAVARES, 2008, p. 35, sublinhado nosso).

Outro ponto a ressaltar na série Os Senhores consiste no estranhamento provocado pelo teor das narrativas, como se pode ver pelo rápido desenrolar das ações que mudam radicalmente a vida do senhor Walser, enquanto em outras há maior estabilidade e quase nenhuma mudança, como ocorre com os senhores Calvino e Juarroz.

É, portanto, na casa, que figurativiza a sala de visitas, que os profissionais entram e saem sem pedir licença, invadindo o espaço idealizado por seu dono, tomando até mesmo a decisão de passar a noite ali, já que os trabalhos não estão terminados. Aos poucos e de modo invasivo, eles acabam por desmontar simultaneamente a casa e o ideal de Walser. Mal ele toma posse da casa recém-acabada, alguém toca a campainha:

Nem há duas horas está Walser na sua nova casa e eis que recebe a primeira visita, mesmo antes do primeiro sono desse primeiro e algo incômodo, pensa Walser, dadas as circunstâncias, afastamento do prazer que sente o seu corpo no novo espaço - aqui vem uma companhia (Idem, p. 23).

A chegada do encanador, todavia, ainda que desagradável, não chega a tirar de Walser a alegria de estar na sua nova morada: "Uma torneira ainda não estava terminada? Pois bem, que sabia ele de tais assuntos[?]" (Ibid., p. 25).

Depois do encanador vão chegando outros "visitantes", que, aos poucos, se apoderam ruidosamente da casa de Walser. Oscilando entre a esperança 
de que tudo termine rapidamente, às vezes Walser desanima, especialmente quando vê que tudo é mais complicado do que parecera à primeira vista: "Quanto mais objetos estivessem à vista mais tempo demoraria o homem a sair. E Walser, minutos atrás, detectara mais coisas do que agora. Sem dúvida, pois, que o movimento era como de refluxo, de recuo - o que o deixava satisfeito. Está quase a sair, pensou" (Ibid., p. 31).

Mas a realidade logo se abate sobre o proprietário, tal a quantidade de homens e consertos espalhados por todos os cantos. Ao perguntar a um deles se vão cortar a luz, "Ninguém respondeu. Todos estavam em atividade generosa" (Ibid., p. 37).

Está aí, portanto, estabelecida a nova ordem de poder: ainda que na posição de "visitantes" e de pessoas indesejadas, estes vão adquirindo um domínio crescente e de absoluta intrusão sobre aquele senhor e o seu espaço. O que antes representava o ideal de moradia, em questão de horas se torna um ambiente inóspito para o seu dono, rompendo com a ilusão do sonho de convívio ameno:

Talvez estivesse inebriado com a novidade do espaço, o certo é que não tinha dado por qualquer incompletude, quer nas coisas mais ou menos concretas que diziam respeito a si próprio - nessa sensação de estabilidade que reúne estados musculares, ritmos respiratórios e um inegável conforto de espírito que jamais ser algum poderá desenhar - quer nas coisas da casa (Ibid., p. 25, sublinhado nosso).

Todavia, e apesar de tudo, o otimista senhor Walser tenta ainda receber de modo hospitaleiro os invasivos visitantes, que ali pernoitariam, de modo a prosseguir com os consertos no dia seguinte:

Walser, embora já cansado, mantinha toda a sua energia concentrada na hospitalidade: procurou cobertores, foi buscar dois colchões, almofadas - tentava enfim que ninguém se sentisse desconfortável na sua casa. [...] De resto, já não lhe pediam permissão, fato a que não dava demasiado relevo, [...]. O espaço já não permitia grandes exigências de delicadeza. 
Que durmam por aí todos - pensou Walser, sem reprimir em si o sentido de proteção que o caracterizava. Já caiu a noite[!] (Ibid., p. 45, sublinhado nosso).

É de notar que, na narrativa do senhor Walser, tal como na do senhor Breton, ocorre uma luta entre as duas forças identificadas por Nietzsche (BENCHIMOL, 2003) em sua teoria: a dionisíaca e a apolínea. No caso do primeiro senhor, as forças da natureza representam a esfera dionisíaca, do crescimento aparentemente desordenado da floresta, do ambiente silvestre que morre e se renova, em contraste com a construção da casa, representativa da esfera apolínea, fruto de planejamento intencional e cuidadoso, segundo cálculos de engenharia, o que ocorre dentro de parâmetros arquitetônicos definidos. Ao final da narrativa, com a intervenção radical dos profissionais, prevalecem as forças dionisíacas da dissolução, que regem a desconstrução do imóvel.

Em O senhor Walser (TAVARES, 2008), o castigo que se abate sobre ele, qual seja, a invasão da sua privacidade e a destruição do imóvel pelos profissionais dos reparos, pode ser atribuído à sua iniciativa de ocupar o espaço da floresta com a construção de uma casa, o que constituiria um erro, aproximando esta narrativa do protogênero do romance de aventuras e costumes, tratado em pormenor no Capítulo III.

No início, a floresta, como entidade viva, reage à invasão, não cessando de produzir obstáculos naturais, representados pelo crescimento ininterrupto de ramos, folhas e galhos, os quais impedem a passagem pela estrada que conduz até a casa. Opondo-se a este desenvolvimento natural, o senhor Walser intervem, cortando e "limpando" o que ele considera uma intrusão contínua da natureza.

$\mathrm{Na}$ luta entre homem e floresta, Walser sobrepõe, com vantagens, 0 poder de homem civilizado. A busca pelo espaço natural da floresta se dá em vista do seu desconforto em relação à cidade, no caso, O Bairro. Outra motivação é o desejo de convivência social em um espaço cuidadosamente escolhido e justificado, razão esta que "não deve ser confundida com uma 
estúpida e inconsciente entrega ao barulho disforme de uma cidade" (Idem, p. 13).

Em monólogo interior, o senhor Walser, ao mesmo tempo em que anseia pela proximidade do ambiente natural para escapar ao "barulho disforme" da cidade, revela certo desapreço pelas características intrínsecas das coisas vivas:

Situada a uns bons quilômetros do bairro mais próximo, a
construção estava rodeada, [...], de uma concentração de
natureza nada receptiva a caminhares solitários, tal o
emaranhado de galhos de árvores que pareciam por vezes
absolutamente incontroláveis - como que dementes; [...] (Ibid.,
p. 13, sublinhado nosso).

A antropomorfização da natureza que, segundo o senhor Walser, aparenta demência e descontrole, também se estende à estrada, a qual, "[...] tinha de ser defendida - como se se tratasse de uma donzela - não a cada dia, é certo, mas definitivamente (pelo menos) a cada mês, dos avanços silenciosos, mas absolutamente eficazes, da floresta" (Ibid., p. 13).

Para este fim, ele compra um machado "[...] de dimensões significativas, bem guardado é certo, (quase escondido) num dos compartimentos da casa de mais difícil acesso, pois tal objeto era para Walser uma quase indesculpável infiltração de agressividade num espaço - o seu - que fora construído para atrair o oposto: a cordialidade, [...]" (Ibid., p. 14). Aí estaria configurado o "erro" de Walser, que corresponde ao mesmo tipo de falha retratada no protótipo, e que acaba por lhe trazer sérias consequências.

Ao bucólico espaço escolhido pelo senhor Walser não deve faltar, porém, a conexão informativa do que se passa nO Bairro, representada pela rotina do recebimento do jornal diário, única ligação direta com a civilização:

Sabia bem que o afastamento geográfico da sua casa em relação a um certo centro onde a frequência de acontecimentos parece obedecer a outras regras fazia incidir sobre o papel fraco do jornal uma outra luz. Tratava-se, afinal, de manter a 
presença física, e de certa forma também espiritual, dos acontecimentos humanos (Ibid., p. 12).

À medida que se aprofundam os consertos, o que poderia, à primeira vista, parecer um processo de melhoria e acerto dos problemas havidos na casa, torna-se, de fato, outra rotina, a do caos e da desconstrução, povoada por ruídos hostis e intrusos desconhecidos:

As pancadas, no entanto, aumentavam, dir-se-ia, de
intensidade. O que parecia a princípio ser apenas efeito de
uma qualquer brisa desnorteada, perdida do rumo sensato da
sua comunidade, era agora, para Walser, uma evidente
ameaça - mas ameaça não argumentada; ameaça sem causas
$\underline{\text { e sem exigências (Ibid., p. 43-44, sublinhado nosso). }}$

Para Mikhail Bakhtin, a questão dos cronotopos foi objeto de estudos minuciosos, constituindo estes os centros organizadores dos acontecimentos temáticos no romance, isto é, geradores da diegese, sendo também neles "[...] que os nós do enredo são feitos e desfeitos" (BAKHTIN, 1988, p. 355). Desse modo, para o autor, "[...] o tempo adquire um caráter sensivelmente concreto; no cronotopo, os acontecimentos do enredo se concretizam, ganham corpo e enchem-se de sangue" (Idem, p. 355).

Tal concretização pode ser apreciada, no caso do senhor Walser, à medida que os eventos relativos aos consertos Ihe vão, aos poucos, destruindo a casa, deixando-a com uma visível aparência de demolição em pleno andamento. Dessa forma, num crescendo, avolumam-se os nós do enredo, adensando-se o tempo/espaço físico e emocional, no qual a personagem se vê inexplicavelmente enredada.

O que no mundo social se poderia caracterizar como uma eventualidade, isto é, alguns poucos consertos requeridos após o término de uma construção, na narrativa do senhor Walser chega ao extremo, dado o número de intervenções supostamente necessárias.

Do momento em que o feliz senhor Walser entra na posse do seu imóvel recém-terminado até chegar ao ponto do quase não reconhecimento do lugar 
em que está, ocorre uma aceleração do tempo no eixo diacrônico, avolumandose a densidade emocional que acompanha, em paralelo, as ações do enredo, as quais se desenrolam sucessiva e rapidamente no plano temporal. O mesmo ocorre na narrativa do senhor Breton, em que o crescente grau de densidade dos questionamentos sinaliza também uma aceleração temporal.

A intensidade emocional nas narrativas dos senhores Brecht, Breton e Walser se refere à condensação e à concretização espaciais das marcas temporais, isto é, o tempo biográfico e o tempo histórico, que se desenrolam em áreas definidas do espaço, oferecem um terreno substancial para o que Bakhtin (Ibid., p. 355, grifo do autor) denomina de "imagem-demonstração" dos acontecimentos.

Desse modo, os eventos ocorrem em dado tempo/espaço, ou em torno dele, servindo de ponto de apoio para o sequenciamento das cenas narrativas, as quais, nos diferentes cronotopos, adquirem feições peculiares, enquanto outros acontecimentos de ligação, afastados do cronotopo central, são fornecidos apenas como informação.

Outro aspecto relevante, presente nas narrativas de Gonçalo M. Tavares, diz respeito à sinalização de diferenças fundamentais, como as existentes entre autor e ouvinte-leitor, entre o mundo real representante e o mundo representado na obra, entre o autor-criador da obra e o autor-indivíduo, entre o ouvinte-leitor de épocas diversas e o ouvinte-leitor passivo contemporâneo. Segundo a concepção de Bakhtin, com relação ao estudo dos cronotopos, não há uma fronteira distinta entre os grupos binários acima. Ocorre, na verdade, uma mescla e uma interação e, às vezes, como que uma interpenetração desses grupos, já que tempo e espaço são mutáveis ao longo do eixo diacrônico, em que nada pode ser tomado como estável. Destarte, Bakhtin prossegue em sua explanação:

[...] é igualmente inadmissível a concepção dessa fronteira rigorosa como absoluta e intransponível [...]. Apesar de toda inseparabilidade dos mundos representado e representante, [...], eles estão indissoluvelmente ligados um ao outro e se encontram em constante interação: entre eles ocorre uma 
constante troca, semelhante ao metabolismo que ocorre entre um organismo vivo e o seu meio ambiente; [...]. Esse processo de troca é sem dúvida cronotópico por si só: ele se realiza principalmente num mundo social que se desenvolve historicamente, mas também sem se separar do espaço histórico em mutação. Pode-se mesmo falar de um cronotopo criativo particular, no qual ocorre essa troca da obra com a vida e se realiza a vida particular de uma obra (Ibid., p. 358-359, grifo do autor, sublinhado nosso).

Ao marcar a inseparabilidade de elementos cronotópicos entre a realidade representada e a representante, simultaneamente à comunhão e à troca inevitável entre elas, o teórico russo levanta uma questão crucial, a qual também está no centro da análise da obra de Tavares neste trabalho: "[...] de que ponto espaço-temporal observa o autor os acontecimentos por ele representados[?]" (Ibid., p. 360).

Responder a tal pergunta significa admitir a veracidade da afirmação bakhtiniana de que a observação do autor se dá "[...] a partir de sua contemporaneidade inacabada, em toda a sua complexidade e completude, encontrando-se ele mesmo (o autor) como que numa tangente da realidade representada" (Ibid., p. 360), isto é, ele se encontra na posição privilegiada de descrever o mundo, em seu tempo/espaço, como se fosse sua personagem, participante efetiva do evento.

Ou ainda, a partir de outra posição, o autor pode também descrevê-lo do ponto de vista do narrador onisciente, como ocorre na maioria das narrativas de Gonçalo M. Tavares, na série de livros que compõe Os Senhores, em que os monólogos interiores das personagens são reveladores do seu estado de espírito, assim como do clima emocional das cenas. Igualmente, como se fora um falso autor, ele pode até mesmo levar a narrativa adiante por si próprio, como o verdadeiro autor, tal qual ocorre no discurso direto do autor.

Para Bakhtin, "O mundo representado, mesmo que seja realista e verídico, nunca pode ser cronotopicamente identificado com o mundo real representante, onde se encontra o autor-criador dessa imagem" (Ibid., p. 360). 
No caso específico da obra Os Senhores, às vezes, é a própria personagem, por meio de suas palavras ou pensamentos, ou ainda o narrador onisciente, quem faz a ponte entre os mundos representante e representado, revelando fatos, eventos, pensamentos, situando cronotopicamente as situações vividas pelas personagens. Assim, o senhor Walser expõe sua alegria ao entrar na casa: "Como Walser está contente! Mal se abre a porta de sua casa - sente ele - entra-se noutro mundo. Como se não fosse apenas um movimento físico no espaço - dois passos que se dá - mas também uma deslocação - bem mais intensa - no tempo; [...]" (TAVARES, 2008, p. 15, sublinhado nosso).

Pode-se, ainda, observar a brusca passagem do cronotopo da sala de visitas para o cronotopo do limiar, marcada pelo curto intervalo de tempo que separa a nova construção, isto é, o ambiente agradável e com cheiro de novo, pronto para receber as pessoas estimadas, e a frieza dos andaimes, espectros que denunciam não apenas os defeitos, mas também a decadência de um imóvel destituído do antigo aconchego:

Claro que esteticamente os andaimes o incomodavam. É que sua casa era nova. Nova não apenas no sentido de ser de construção recente - que diabo, não passara sequer um dia mas também no sentido em que a juventude de uma coisa é definida por uma distância razoável em relação à sua morte. Aquela casa tinha um longo percurso à sua frente, desde essa manhã - o momento da sua inauguração plena; e os andaimes como que anunciavam ou eram já, eles próprios, agora exteriormente, a manifestação de uma fraqueza, de algo que não está a funcionar, da necessidade de uma reparação (Idem, p. 42, sublinhado nosso).

É de se notar aí a associação metafórica da casa nova com a vida humana, que é longa quando se é jovem e, antagonicamente, se torna decadente com a velhice e a proximidade da morte, figurativizadas ambas pelos andaimes, os quais sustentam, como uma bengala ou muletas, aquele que não é mais capaz de se manter de pé sozinho. Desse modo, o cronotopo 
do limiar adquire aqui a função semântica da decrepitude, do que se desfaz diante dos olhos, e da morte em si.

Em O senhor Breton e a entrevista (TAVARES, 2009) o cronotopo da sala de visitas corresponde ao tempo/espaço da entrevista. Aí se dá o embate entre as duas partes do senhor Breton, nas personae do entrevistador e do entrevistado. De forma a concretizar a cisão das duas partes do Eu, a personagem faz uso de um espelho, que the permite ver a si mesmo e ao Outro: "O senhor Breton colocara um enorme espelho na sala: a janela com a velocidade ideal. Virou-se de novo para o espelho e, confirmando que o gravador continuava funcionando, fez a segunda pergunta" (Idem, p. 12).

A "janela com a velocidade ideal" (p. 12) representa para o senhor Breton, um homem reflexivo, o tempo em seu transcurso regular, sem acelerações ou compressões, já que o tempo/espaço da entrevista deve ter a duração de que ele necessita para refletir, indagar e inteirar-se das questões.

O senhor Breton, da posição de entrevistador, é o único que fala durante a entrevista, seja fazendo afirmações, teorizando, indagando, formulando hipóteses. Solicita ao senhor Breton, o entrevistado, confirmações ou refutações às suas teorias e opiniões, cujas respostas não são verbalizadas: "É isto? Concorda, senhor Breton[?]" (Ibid., p. 12). Ou ainda: "Não sei se o senhor subscreve esta definição, senhor Breton[?]" (Ibid., p. 16). O entrevistado manifesta apenas o seu crescente desconforto ao longo de toda a entrevista, seja por gestos, distrações, ou mudanças de posição.

Nesse caso, o cronotopo da sala de visitas não é o palco das revelações óbvias e materiais, como seria de esperar em uma entrevista, mas se torna 0 tempo/espaço das grandes questões, as quais são respondidas, em parte, pelo próprio entrevistador, que fica à espera da confirmação ou não das respostas. Trata-se de um tempo/espaço de grande densidade psicológica e emocional devido ao tipo de questionamento colocado pela personagem à outra parte de si.

As perguntas constituem indagações e especulações de ordem complexa que afligem o homem contemporâneo, em contraponto a outras, que 
ele julga essenciais, quais sejam, a arte, a poesia e a literatura. Ao entrevistar a si mesmo, o senhor Breton busca, na verdade, o autoconhecimento. Ao perguntar ao outro senhor Breton, o entrevistado, o entrevistador quer repostas para os seus próprios questionamentos. Vale ressaltar que, segundo Bakhtin, é no cronotopo da sala de visitas que se dão

[...] os diálogos que adquirem um significado extraordinário no romance, revelam-se os caracteres, as "ideias" e as paixões dos heróis. [...]. Lá estão condensados, concentrados os signos patentes e visíveis tanto do tempo histórico, como também do tempo biográfico e cotidiano, e, simultaneamente, eles estão reunidos na imagem mais densa, fundidos nos signos unitários da época, que se torna concreta e tematicamente visível (BAKHTIN, 1988, p. 352-353, grifo do autor, sublinhado nosso).

O senhor Breton, logo na primeira pergunta, se debruça sobre o medo e a incerteza humanos, bem como o tédio, que se apossam do indivíduo, seja ele qual for, chegando, então, à poesia, que, intangível, é capaz de resolver o medo, a insegurança e o tédio:

E a poesia que parece uma coisa parada, resolve, ao mesmo tempo, o tédio e o medo; o que é bom e dois, sendo uma única, a poesia. Uma coisa que caminha, ao mesmo tempo, para seu lado direito e para o esquerdo não é uma coisa útil (porque a utilidade é tema de medidas exatas e previsões em gráficos), é, sim, uma coisa sagrada e mágica (TAVARES, 2009, p. 11, sublinhado nosso).

Ao ressaltar a importância da poesia, o senhor Breton sinaliza no sentido de que certas questões da contemporaneidade, como o utilitarismo exacerbado das coisas concretas que podem ser calculadas, medidas e pesadas, podem encontrar resposta no imaterial, na arte, na poesia. Nesse sentido, ao falar do homem contemporâneo, Zygmunt Bauman cita Umberto Eco, trazendo apropriadas asserções quanto às dúvidas manifestadas pelo homem da pósmodernidade, diante das quais se coloca também o senhor Breton: 
É na ficção, afirma Eco, que procuramos a espécie de certeza e segurança intelectual que o mundo real não pode oferecer... Lemos romances a fim de localizar uma forma na informe quantidade de experiências terrenas. Participamos de um jogo, mas dele participamos a fim de instilar sentido na profusão de fenômenos terrenos - procuramos abrigo contra a Angst, essa profunda ansiedade que nos acossa sempre que desejamos dizer algo a propósito do mundo, com segurança (ECO, 1994 apud BAUMAN, 1998, p. 151-152, grifo do autor, sublinhado nosso).

Ainda em 0 senhor Breton e a entrevista (TAVARES, 2009), o tédio, representado pela segurança da casa, e o medo, metaforizado na escuridão da noite fora da casa seriam solucionados, para o senhor Breton, pela poesia, que se coloca no intermezzo entre a segurança monótona e a incerteza causada pelo desconhecido, figurativizada na porta, que não está nem de um lado nem de outro, ou seja, nem dentro da casa, "onde há a tranquilidade e o esperado" (p. 11), nem do lado de fora, em que existem "o medo e a estranheza" (p. 11), representados pela noite escura.

O senhor Breton, simultaneamente entrevistador e entrevistado no decorrer de toda a entrevista, faz mais afirmações e teoriza do que propriamente pergunta. Em sequência às suas explicações e teorias, às suas formulações e ilustrações, o senhor Breton verifica sua imagem no espelho para certificar-se de que está ali, de que se trata mesmo da sua pessoa e do Outro que ele vê no espelho, e confere o gravador ligado. E ele prossegue, com poucos momentos de descanso.

Aqui ainda não aparece a grande tensão que se configurará de forma aguda mais adiante, à medida que segue a entrevista. A importância da poesia, com seu dinamismo e poder transformadores, é o foco principal do questionamento do senhor Breton neste entrecho, em que o entrevistador formula seu arrazoado:

$\underline{O}$ verso debaixo da pele não é o mesmo que uma dor ou que a inflamação de um órgão. Não se elimina com medicamentos. $\underline{\mathrm{O}}$ verso que um homem saiba de cor só é eliminado por uma 
brutal amnésia. Ou, então, com o excesso de informação que o mundo imbecil o obriga a guardar. Porque um verso não tem o timbre de uma informação. Só para dar um exemplo: os homens que se erguem não são da mesma espécie animal que os homens que são derrubados e aí ficam. É isto? Concorda, senhor Breton[?] (Idem, p. 11-12, sublinhado nosso).

O mesmo tema é retomado na segunda pergunta, em que se aprofunda a crítica ao homem da contemporaneidade, preocupado com os aspectos concretos e periféricos da vida, perdendo, por conseguinte, a visão do essencial, do imaterial e do belo. Tal aprofundamento adensa o tom e o ritmo da entrevista, caracterizando cada vez mais o cronotopo da sala de visitas como o tempo/espaço da intensidade emocional. Assim, prossegue o entrevistador, ao contrapor, metaforicamente, o concreto ao imaterial, o essencial ao supérfluo:

O problema das fórmulas da Física e das fórmulas dos versos é que umas e outras não são orgânicas como a relva, a terra, a chuva, o alimento em cima da mesa e o frio. Porque as fórmulas não são mais do que o congelamento de uma explicacão. [...]. O problema, então, dos raciocínios verbais numéricos, ou mesmo das aparições de palavras que constituem certos versos, o problema então deste Mundo, que nasceu da cabeça dos homens, é que nada disto é comestível. E é assim mesmo; desculpe senhor Breton [...]. Quando mulheres de longos cílios [...] e homens de coração inconstante dizem que a poesia é seu alimento, vê-se bem que nunca passaram fome (Ibid., p. 15, sublinhado nosso).

Pela primeira vez, o senhor Breton interrompe a entrevista ao parar o gravador, olhar para o espelho e pensar no senhor Juarroz. Da posição de entrevistado, ele se imagina com o mesmo problema do vizinho, que é a incapacidade de, ao mesmo tempo, pensar em uma coisa e vê-la. Lembrou-se também do que o senhor Juarroz lhe contara a respeito da ideia de que se fosse cego, "[...] poderia pensar continuamente, sem qualquer interrupção 
imposta pelo mundo visível. A cegueira como libertação, de certa maneira" (Ibid., p. 17).

A partir da terceira pergunta, as analogias e metáforas em relação à poesia se tornam mais complexas e profundas, abordando a natureza etérea da poesia. As perguntas, então, se tornam mais incisivas e vão, progressivamente, acuando o entrevistado, que sequer concorda ou discorda:

Uma rosa, apesar de bela, tem uma parte acastanhada e suja que está debaixo da terra. E um verso é como uma planta: é belo investigar-se a terra que o destino the colocou por baixo. A beleza será, pois, uma profundidade e não um tamanho, muito menos uma cor ou uma forma. Concorda com este raciocínio, senhor Breton? Concorda com este modo de ver as coisas[?] (Ibid., p. 20, sublinhado nosso).

Em uma de suas analogias, o senhor Breton usa imagens referentes à anatomia humana em comparação com a poesia, a arte, a ciência e a cultura em geral. Neste caso, ao usar de elementos anatômicos, como os ossos, o senhor Breton busca mostrar o que está mais próximo e é mais concreto, em oposição às ideias, às obras literárias e à filosofia, que estão em nível mais profundo e intangível:

Porque a anatomia é algo que existe oculto dentro do corpo; é interior como as imagens mentais, apesar de menos interior do que as imagens mentais. Porque um osso, parece-me, existe, apesar de tudo, em lugares menos fundos do que as ideias ou os raciocínios. [...]. Se fizermos uma escavação, com instinto arqueológico, descobriremos, primeiro, a tíbia e o perônio, e só depois certas células inteligentes. [...]. Por outras palavras: $\underline{0}$ corpo humano compreende equações de segundo grau e o texto de um filósofo num lugar mais profundo do que o fundo onde os ossos estão. Se a anatomia humana, em termos de profundidade, terminasse nos ossos, a humanidade ainda não teria escrito a Odisseia ou o / Ching, nem existiria a fórmula $E=m^{2}$ (Ibid., p. 13-14, grifo do autor, sublinhado nosso). 
Também pela primeira vez, desaparece da relação dialógica estabelecida anteriormente a figura do entrevistado, já que, diante das perguntas do entrevistador, ele nada responde. A única resposta vem do próprio entrevistador: "O senhor Breton não respondeu. Estava ali para fazer perguntas apenas" (Ibid., p. 21).

Nesse momento, manifesta-se a persona do entrevistado, que, coagido pelos raciocínios complexos do entrevistador, e incapaz de refletir, tem seu pensamento revelado pelo narrador onisciente, justificando o fato de não estar disposto a pensar sobre os questionamentos, e muito menos a respondê-los:

O senhor Breton acreditava que a realidade era complicada devido aos analfabetos estarem sempre perguntando, frente a uma frase escrita: o que é que isto quer dizer? São as perguntas que complicam a realidade. Sem perguntas, a realidade seria simples - pensava o senhor Breton (Ibid., p. 21, sublinhado nosso).

Nota-se aí uma crítica aguda ao homem contemporâneo, que não tem tempo ou disposição para questionamentos profundos, lidando apenas com a superficialidade dos problemas imediatos, homem que vive, segundo Giddens (2002, p. 22), em um "mundo em disparada".

Na nona pergunta, o senhor Breton, na posição de entrevistador, afirma que "Uma águia é feita da mesma matéria que o verso. Para observá-los (à águia e ao verso) o homem terá de levantar a cabeça até que o pescoço the doa; e para respeitá-los, terá de curvar a cabeça, até que, de novo, o pescoço Ihe doa" (TAVARES, 2009, p. 50, sublinhado nosso).

Ao chegar à décima pergunta, o senhor Breton compara alegoricamente patos a águias:

Os patos entram no ar como escravos, modestos e obedientes; enquanto as águias avançam, como certos imperadores na sala de acesso ao poder. E o poeta deve entrar num verso como a águia entra no ar. Não como um pato. [...]. E chegado à sala do dinheiro, do poder e da ambição, deve o animal orgulhoso urinar, como os loucos, no centro da sala; e depois, 
sim, sair. Será isto, senhor Breton[?] (Idem, p. 53, sublinhado nosso).

No entrecho comparativo, o senhor Breton contrapõe a materialidade à intangibilidade, a beleza à deselegância, a modéstia servil à altivez do que se sabe majestoso, tal como a águia e o poeta do verso perfeito. Ambos, poeta e águia, representam a possibilidade da transgressão desejável, a ousadia, o que está para além da concretude mesquinha, como é o caso "do dinheiro, do poder e da ambição" (p. 53).

Os objetivos imateriais, e que por isso devem ser buscados, são, para o senhor Breton, os mais difíceis, já que custam não somente dor, mas a consciência de que existem. Por isto, "O poeta deve entrar num verso como a águia entra no ar" (p. 53), ambos leves e precisos. Como consequência, os que buscam o sensível imaterial devem se afastar, com desprezo, da ganância, do dinheiro e do poder. A tentativa de agarrar o verso e o vôo da águia é o que pode permitir, eventualmente, e em contrapartida, transcender:

No meio do caminho de um verso deve pois o poeta perder a certeza com que começou, terminando assim o verso com uma outra certeza, uma segunda certeza. Sem obras de reconstrução, uma casa cai, em ruínas, assim também um verso. [...]. O mais forte rochedo é aquele que conseguimos desenhar, mas não agarrar. $\underline{O}$ verso perfeito é irmão daquilo que não conseguimos agarrar (Ibid., p. 50, sublinhado nosso).

Ao final da décima pergunta, a tensão chega ao ponto máximo, caracterizando a intensidade emocional e a confrontação existentes no cronotopo da sala de visitas. Diante de todos os questionamentos do senhor Breton, na posição de entrevistador, o entrevistado fica mudo: "O senhor Breton ficou em silêncio. Não sabe o que responder" (Ibid., p. 51).

De todos os senhores da série, o que apresenta maior mudança no decorrer da narrativa é o senhor Breton, cujo processo transformacional diante do esgotamento que viveu durante a entrevista, e mesmo sendo um homem pacífico, sente, ao final, o desejo de matar o primeiro vizinho a passar sob a 
sua janela, atirando-Ihe na cabeça uma moeda, como se depois de todos os temas abstratos tratados, a materialidade do dinheiro representasse a solução pela violência. Nota-se aí a ira da personagem por tudo o que passou, principalmente pelo sofrimento a que foi submetido, na posição de entrevistado:

Pensou então se, daquela altura, atirando com força uma moeda na cabeça de alguém, se a moeda seria capaz de matar. Uma moeda, atirada com força e batendo em cheio na cabeça. Há pontos do cérebro tão sensíveis que se, a uma certa velocidade, uma moeda, por mais baixo valor que tenha, acertá-los, a pessoa morrerá, murmurou (Ibid., p. 54, sublinhado nosso).

Esta mudança do senhor Breton, que é de aparente revolta e cansaço pela tensa entrevista, e que, ao final, o faz pensar em matar um vizinho inocente, é, na verdade, o corolário dos seus pensamentos, expostos nas perguntas. De modo consciente agora, o senhor Breton, da posição de entrevistado, "responde" e "confirma" as afirmações do senhor Breton, da sua posição de questionador, concretizando, com a fúria final, o desprezo pelo que é material e transitório. Ocorre aí como que uma reunião das duas metades cindidas desse senhor, o que é induzido pelas reflexões e questionamentos propostos pela parte correspondente ao entrevistador.

Dois elementos aparecem de forma marcante na narrativa do senhor Breton: o espelho e a janela. Trata-se de entidades paralelas, representando ambas, não apenas a abertura para dentro, o olhar para si mesmo, na direção do seu mundo interior, mas também, metaforizando as duas a abertura para 0 mundo externo, o ponto de onde é possível ver o Outro, o não Eu, o mundo lá fora.

Outro ponto a ressaltar é a ironia presente nas falas do entrevistador ao comentar suas proposições:

E a falta que faria ao nosso cotidiano: ao comer, ao beber, ao dormir, ao trabalhar, ao amar: que falta faria aos nossos hábitos a fórmula, essa fórmula: $\mathrm{E}=\mathrm{mc}^{2}$ ! Como conseguiríamos apaixonar-nos? E matar? Como conseguiríamos ser mortos? 
Ironia, claro, senhor Breton (disse o senhor Breton enquanto se reposicionava frente ao espelho), mas aqui reside o centro da questão que coloco: o que fará mais falta aos dias do animal humano: a fórmula $E=m c^{2}$ ou os versos de Rilke[?] (Ibid., p. 14, sublinhado nosso).

A exaltação da poesia e da arte feita pelo senhor Breton, o entrevistador, põe em patamar inferior as descobertas e teorias científicas, opondo, dessa forma, a natureza mais concreta das ciências empíricas ao etéreo intangível da poesia e da filosofia. Todavia, a ignorância da maioria dos homens em relação ao conhecimento como um todo também é alvo da crítica ácida do entrevistador:

Alguns céticos da Literatura e da Física dirão que nem a falta de um nem do outro perturbarão o cotidiano de $99 \%$ dos habitantes de qualquer cidade. E dirão ainda que a falta de uma casca de pão na hora do almoço ou um mero engarrafamento perturbam bastante mais o dia de um cidadão que o esquecimento das fórmulas da Física ou das fórmulas da vida (a poesia) (Ibid., p. 14-15, grifo sublinhado nosso).

A conformação do cronotopo da sala de visitas, no caso da entrevista do senhor Breton, apresenta particularidades que se ajustam à natureza da narrativa contemporânea de Gonçalo M. Tavares, e que são, por esta razão, diferentes daquelas estabelecidas por Bakhtin (1988) ao tratar do mesmo cronotopo, cuja importância está no fato de sua íntima relação com o cronotopo do encontro de modo geral.

As adaptações sofridas no eixo temporal pelo cronotopo da sala de visitas, em O senhor Breton e a entrevista (TAVARES, 2009), permitem diferenciar as características deste cronotopo, presentes também nos romances de Balzac e Stendhal, configurando um novo lugar "para a realização das peripécias do romance", segundo Bakhtin. Para o autor russo, observa-se em tal tempo/espaço, 
[...] o entrelaçamento do que é histórico, social e público com o que é particular e até mesmo puramente privado, de alcova; a associação da intriga pessoal e íntima com a intriga política e financeira, do segredo de Estado com o segredo da alcova, da série histórica com a série biográfica e de costumes. Lá estão condensados, concentrados os signos patentes e visíveis tanto do tempo histórico, como também do tempo biográfico $\mathrm{e}$ quotidiano, e, simultaneamente, eles estão unidos na imagem mais densa, fundidos nos signos unitários da época, que se torna concreta e tematicamente visível (BAKHTIN, 1988, p. 352-353, sublinhado nosso).

No caso do senhor Breton, a entrevista não soluciona os nós do enredo, nem o sucesso ou o revés de um projeto, como no cronotopo canônico da sala de visitas, segundo Bakhtin. Antes, os questionamentos são propostos como objeto de reflexão, mais do que apontam para a resolução de conflitos existenciais.

Do mesmo modo que existe no senhor Walser o anseio pelo encontro com uma companheira e amigos, e para isto ele procede à construção da casa, o senhor Breton não deseja apenas o encontro consigo mesmo, o que se dá por meio da entrevista, mas também com o Outro. Em ambas as narrativas, é o motivo do encontro, mencionado por Bakhtin (1988, p. 222), o gerador diegético que estabelece a natureza das falas das personagens, a exposição de suas ideias, o seu fazer dentro da narrativa. Segundo o teórico,

Em qualquer encontro [...] a definição temporal ("num mesmo tempo") é inseparável da definição espacial ("num mesmo lugar"). E no motivo negativo - "não se encontraram", "se separaram" - a cronotopicidade é mantida, mas um ou outro membro do cronotopo é dado com um signo negativo; [...]. A unidade indissolúvel (mas não a fusão) das definições temporais e espaciais traz ao cronotopo do encontro caráter elementar, preciso, formal e quase matemático. Mas, naturalmente, esse é um caráter abstrato. Pois o motivo do encontro é impossível isoladamente; ele sempre entra como elemento constituinte da composição do enredo e da unidade 
concreta de toda a obra e, por conseguinte, inclui-se no cronotopo concreto que o engloba, $[\ldots]$ (Idem, p. 222, grifo do autor, sublinhado nosso).

Na verdade, as "perguntas" feitas pelo senhor Breton à sua outra parte constituem em si mesmas as respostas do entrevistado, já que é ele próprio o formulador das teorias, das ideias e dos questionamentos sobre os quais discorre. Em certo momento, ele completa: "Mas a realidade não bastava, faltava a outra metade: a reflexão" (TAVARES, 2009, p. 21). Nota-se aí a alternância das duas posições, por meio das quais, o entrevistado busca simplificar o que considera complicado, enquanto o entrevistador deseja forçar a reflexão.

A mudança de lugar na cadeira, o olhar pela janela, outros movimentos denotativos do cansaço do senhor Breton, na posição de entrevistado, se manifestam ao fim de cada pergunta. Em um intervalo, após contemplar a passagem do senhor Valéry, o senhor Breton ri do vizinho, que caminha pela rua calçado com dois sapatos direitos, o que leva o senhor Breton a pensar na teoria do senhor Valéry: "Se calçarmos dois sapatos esquerdos iremos sempre para a esquerda e se calçarmos dois sapatos direitos iremos sempre para a direita" (Idem, p. 25).

O que mais agrada ao senhor Breton é ter, mesmo que à distância, contato com seus vizinhos, o que se evidencia no emprego do verbo "maravilhar-se", revelado em monólogo interior:

Da janela, entretanto, o senhor Breton maravilhava-se com aquilo. $O$ senhor Valéry queria agora ir para o lado esquerdo do bairro: e ali estava ele calçando dois sapatos esquerdos. Mas, de repente, o senhor Breton ouviu um estrondo. Era a porta do prédio ao lado. A delicada senhora Woolf acabara de sair. $O$ senhor Breton terminou de fumar. Afastou-se da janela e voltou ao espelho. Era tempo de recomeçar a entrevista (Ibid., p. 26, sublinhado nosso). 
No contexto ambivalente de posicionamentos distintos da personagem, ora como entrevistado ora como entrevistador, estabelece-se o confronto dual entre as partes: o primeiro é praticamente forçado pelo segundo a manifestarse, o que o coloca, aos poucos, no cronotopo do limiar, também chamado de cronotopo da "soleira", que constitui um tempo/espaço de crise e tensão intensas.

Segundo Mikhail Bakhtin, tal cronotopo se configura de modo mais substancial e completo que o próprio cronotopo do encontro. Para o autor russo, o limiar

[...] é o cronotopo da crise e da mudança de vida. A própria palavra "soleira" já adquiriu, na vida da linguagem (juntamente com seu sentido real), um significado metafórico; uniu-se ao momento da mudança da vida, da crise, da decisão que muda a existência (ou da indecisão, do medo de ultrapassar o limiar). Na literatura, o cronotopo da "soleira" é sempre metafórico e simbólico, às vezes sob uma forma aberta, mas, com mais frequência, implícita. [...], o limiar e os cronotopos da escada, da ante-sala, do corredor, que the são contíguos, e também os cronotopos da rua e da praça, que lhes seguem, [...] são os principais lugares da ação [...], são os lugares onde se realizam os acontecimentos das crises, das quedas, das ressurreicõos, dos renascimentos, das clarividências, das decisões que determinam toda uma vida. Nesse cronotopo o tempo é, em suma, um instante que parece não ter duração e sai do curso normal do tempo biográfico (BAKHTIN, 1988, p. 354, grifo do autor, sublinhado nosso).

As rotinas dos senhores seguem, em geral, monótonas, sofrendo quebra em casos excepcionais, como ocorre com o senhor Breton, para quem a entrevista representa uma ruptura dolorosa no seu cotidiano. Assim, o hábito deste senhor de caminhar pela rua quando se sente cansado e precisa de distração, não se interrompe pela entrevista. Ao contrário, a saída para um passeio alivia o cansaço que o embate sem tréguas insiste em lhe impor. Tais 
passeios também são significativos pelos eventuais encontros com os vizinhos dO Bairro:

Parou a gravação, dirigiu-se à porta do apartamento e saiu. Precisava andar. Precisava desacelerar. Apesar de aquele edifício ser extremamente povoado, não cruzou com ninguém nas escadas. Saiu à rua e começou a andar. Nas ruas do bairro, passou pelo senhor Duchamp (TAVARES, 2009, p. 2829).

As ilustrações colocadas no alto de quase todas as páginas ímpares do livro, como nas páginas $11,13,15$, etc., mostram um mecanismo semelhante ao de um relógio mecânico com suas engrenagens que, todavia, se move ora em sentido horário ora em sentido anti-horário, contrariando, por seu movimento inusitado, a naturalidade usual do transcorrer do tempo. O senhor Breton, na posição de entrevistado, é representado, nas ilustrações ${ }^{9}$, por uma letra B presa ao dente de uma das engrenagens. A mudança de posição da letra B nas sucessivas páginas ímpares revela o passar do tempo, figurativizando o processo opressor a que é submetido o entrevistado.
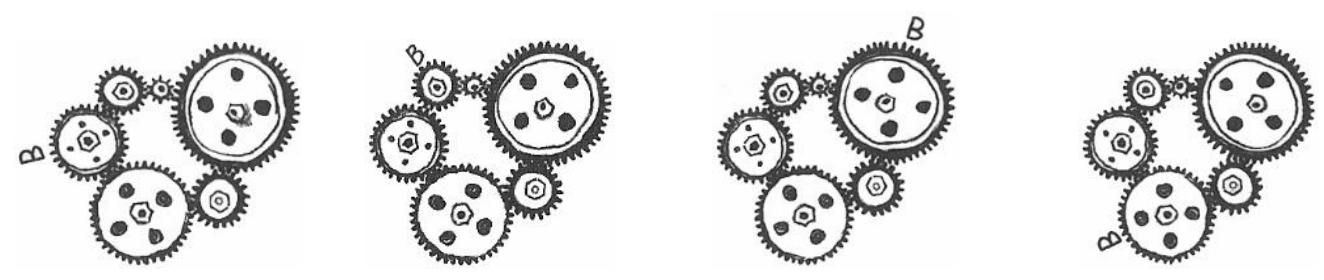

A simbologia da ilustração, bem como a sua repetição, revela o indivíduo preso a um sistema do qual não é possível escapar, estando a personagem igualmente refém do tempo cronológico que não para, não the dando sequer tempo para respirar durante a entrevista, e que, ao lembrar também um aparelho de tortura, coloca o entrevistado em situação de sofrimento, à medida

\footnotetext{
${ }^{9}$ Desenhos de Rachel Caiano. In: TAVARES, Gonçalo M., O senhor Breton e a entrevista, Rio de Janeiro: Casa da Palavra, 2009, p. 17, 27, 47 e 53, respectivamente.
} 
que giram as partes metálicas das engrenagens, impondo-Ihe um desconforto cada vez maior.

Em uma saída para a rua, o senhor Breton vê que se aproxima o senhor Kraus, finalmente um vizinho com quem poderá conversar. $O$ encontro entre os dois vizinhos dá mostra aparente de uma aproximação real, chegando ambos ao aperto de mão: "Há uma ciência a inventar - disse o senhor Kraus, [...]. Sim? - questionou o senhor Breton, aliviado por ouvir outra voz que não a sua" (Idem, p. 31). E diante da estapafúrdia teoria sobre a medição da inteligência dos mortos, em que o senhor Kraus fala praticamente sozinho, ao senhor Breton só resta concordar burocraticamente com um aceno de cabeça.

Finalmente, forçado pelo interlocutor a ler os artigos que o jornalista havia publicado recentemente, o senhor Breton se despede do vizinho, "um falador por excelência" (p. 34).

Tais tentativas de aproximação deixam clara a ideia de solidão e carência afetiva dos senhores: não importa estarem todos rodeados por vizinhos, é como se cada um habitasse um mundo particular, inusitado e idiossincrático. A partir do conteúdo da fala do senhor Kraus, é possível perceber que há aí um não diálogo, já que não existe interlocução. O senhor Kraus fala para si mesmo, tal qual o senhor Breton na posição de entrevistador, ambos constituindo mundos separados e incomunicáveis.

É possível considerar que a entrevista do senhor Breton da mesma forma estabelece conexões com o protogênero representado pelo romance de aventuras e costumes, ou seja, o segundo tipo de romance da Antiguidade, configurando-se como um percurso de provações percorrido pela personagem, e que será tratado no Capítulo III.

No caso do senhor Breton, diferentemente do senhor Walser, a provação é auto-imposta: predomina nele o desejo quase obsessivo de se autoconhecer. $O$ diálogo consigo mesmo é praticamente uma missão a ser cumprida, a necessidade forçosa de reflexão sobre temas difíceis e pertinentes, que devem ser considerados, não importando quão complexos sejam, estando o entrevistado subjugado pelo poder do entrevistador.

Nesse sentido, 
A força constitutiva das práticas discursivas está em poder prover posições de pessoa: uma posição incorpora repertórios interpretativos, assim como uma localização num jogo de relações inevitavelmente permeado por relações de poder. As práticas discursivas, portanto, implicam necessariamente o uso de repertórios e posicionamentos identitários (SPINK; MEDRADO, 1999, p. 56, sublinhado nosso).

A propósito do uso do espelho pelo senhor Breton, como adjuvante da entrevista, pode-se perceber, a partir das considerações de Bakhtin, o significado do objeto, por meio do qual, se tem a própria imagem e a do Outro:

Contemplar a mim mesmo no espelho é um caso inteiramente específico de visão da minha imagem externa. Tudo indica que neste caso vemos a nós mesmos de forma imediata. Mas não é assim; permanecemos dentro de nós mesmos e vemos apenas o nosso reflexo, que não pode tornar-se elemento imediato da nossa visão e vivenciamento do mundo: vemos o reflexo da nossa imagem externa mas não a nós mesmos em nossa imagem externa; a imagem externa não nos envolve ao todo, estamos diante e não dentro do espelho; o espelho só pode fornecer o material para a auto-objetivação, e ademais um material não genuíno (BAKHTIN, 2003, p. 30-31, grifo do autor, sublinhado nosso).

A tarefa constituída pela entrevista, comprimida no espaço de dez perguntas, representa o jogo ambivalente de forças opostas que se digladiam dentro da personagem: o seu lado intelectual e inquisitivo versus o seu outro lado, passivo e autoindulgente, que procura fazer escolhas fáceis e cômodas, relegando a um segundo plano as questões de maior complexidade. Daí suas tentativas de escape em virtude do cansaço, nas quais seu pensamento se desvia para lembranças mais agradáveis do que o confronto proposto pelos questionamentos.

Nos dois papéis, O senhor Breton representa as duas forças em luta - a apolínea e a dionisíaca -, segundo Nietzsche (BENCHIMOL, 2003). O 
entrevistador se esforça por fazer indagações profundas, que levem a outra parte de si à reflexão, usando de elementos analógicos e metafóricos conectados às ciências empíricas e, portanto, de difícil compreensão, os quais, ainda que estejam ligados de certo modo à esfera dionisíaca, como a poesia e a arte em geral, também se relacionam com aspectos apolíneos, como os estabelecidos pelos cânones poéticos e literários.

O entrevistado, por sua vez, reluta em refletir e responder às perguntas, procurando, sempre que possível, dar vazão ao seu lado dionisíaco do não pensar, de fugir para o cronotopo da rua, de olhar pela janela para ver quem passa, de distrair-se de alguma maneira, de procurar os amigos para conversas amenas.

O senhor Henri (TAVARES, 2004b, p. 51), por sua vez, tem no bar o equivalente ao tempo/espaço da sala de visitas, conforme descrito por Bakhtin (1988, p. 352). Aquele é o lugar em que este senhor filosofa: “[...] o absinto é a minha teoria sobre o mundo. ... eu tenho um sistema geral do pensamento, chama-se absinto" (Idem, p. 51).

Viciado na bebida, a partir dela o senhor Henri constrói a sua visão de mundo, estabelecendo os paradigmas que regem a sua vida, passada quase inteiramente no bar, que é o equivalente de sua própria casa, ou, melhor que ela, dada a grande oferta de absinto ${ }^{10}$.

Nas narrativas do senhor Henri pode-se novamente recuperar a correlação com a ideia de Nietzsche ${ }^{11}$, que trata do conceito filosófico, o qual

\footnotetext{
${ }^{10}$ absinto: bebida destilada, feita a partir da erva artemisia absinthium ( $\alpha$-Tujona). A $\alpha$-Tujona é um monoterpeno que ocorre em muitas plantas, incluindo espécies do gênero Artemisia. Devido aos seus efeitos alucinógenos, é o componente psicotrópico do absinto, bebida cujo uso recreacional atingiu a popularidade no século XIX e começo do século XX. Os efeitos agudos da a-tujona incluem, principalmente, convulsões, enquanto a ingestão crônica do absinto pode levar a alucinações, sonolência, tremores, convulsões e paralisia, uma síndrome chamada absintismo (Revista Brasileira de Farmacognosia / Brazilian Journal of Pharmacognosy 19 (1A): 140-149, Jan./Mar. 2009). (Ver Referências.)

11 Friedrich Wilhelm Nietzsche (1844-1900): filólogo e filósofo alemão, que adotou posteriormente a cidadania suíça. Ele acreditava que a base racional da moral era uma ilusão e, por isso, descartou a noção de homem racional, impregnada pela utópica promessa - mais uma máscara que a razão não-autêntica impôs à vida humana. O mundo para Nietzsche não é ordem e racionalidade, mas desordem e irracionalidade. Seu princípio filosófico não era portanto Deus e razão, mas a vida que atua sem objetivo definido, ao acaso, e por isso se está dissolvendo e transformando-se em um constante devir. (Ver Referências.)
} 
consiste na ideia de dionisíaco em oposição à de apolíneo, já que o bar, local onde o senhor Henri passa grande parte da vida, é "o lugar de Baco ou Dionísio", onde também são suscitados temas vinculados à ciência e ao conhecimento, ou seja, assuntos ligados ao conceito do que é "de Apolo".

Segundo Marcio Benchimol,

Na apresentação nietzscheana da filosofia pré-socrática o devir toma a forma de dois movimentos contrários compreendidos unitariamente: como movimento de geração dos entes individuais a partir da unidade primordial e como movimento de dissolução destes mesmos entes novamente no seio daquela unidade (BENCHIMOL, 2003, p. 55).

Ainda segundo Benchimol, o primeiro movimento em questão é, para Nietzsche, o de repulsão, caracterizado pela separação de elementos que outrora estiveram unidos; o segundo é referente ao movimento de atração e de reconfiguração da unidade original.

Nessa acepção filosófica, associada à mitologia greco-romana, o primeiro conceito, o dionisíaco, constitui o movimento de afastamento ou de desagregação dos elementos anteriormente unidos; o segundo, em oposição, consiste no movimento de atração e de estabelecimento da primitiva unidade, responsável pela construção do Uno-primordial. De acordo com o autor, a partir da ideia de Nietzsche, o Uno-primordial seria

[...] o deus-artista eternamente empenhado nos movimentos contrários de construir (bauen) e destruir (zerstören). O que Nietzsche designa como construir é o movimento plástico e formador pelo qual o Uno-primordial se alivia de seus tormentos e contradições internos, dando geração a todas as formas particulares nas quais a vida se manifesta. Já o destruir será o movimento pelo qual o Uno-primordial continuamente dissolve e nega toda individualidade particular (Idem, p. 56, grifo do autor). 
Segundo Paula Júnior,

Ao termo Uno-primordial, o filósofo (Friedrich Wilhelm Nietzsche) confere uma noção de ordem ontológica, essencial repleta de dor e contradição, concomitante a um supremo prazer e inconsciência. Ou seja, um plano originário, que tem suas manifestações no mundo das aparências e, nele, cumpre o papel de redenção e cura para o sofrimento. [...]. Essa concepção só pode ser percebida de forma intuitiva e não lógica ou racional (PAULA Júnior, 2006, p. 3, grifo do autor, sublinhado nosso).

Outro filósofo a refletir sobre esse conceito nietzscheano é Friedrich Kaulbach (1979), em seu artigo "Nietzsche e o pensamento monadológico", em que o autor fala sobre a tensão existente entre esses dois movimentos, isto é, "[...] entre plasmação e dissolução, geração e aniquilamento, moldagem e destruição na dança do vir-a-ser [...]" (KAULBACH, 1979 apud BENCHIMOL, 2003, p. 56).

Ainda de acordo com Kaulbach, a oposição entre o apolíneo e o dionisíaco pode ser definida, em suma, como uma "[...] tensão entre a máxima unidade e a máxima multiplicidade" (Idem, p. 131).

Para Benchimol (2003, p. 57), "Isto parece significar que o desequilíbrio entre os dois impulsos, ou seja, a predominância de um deles em relação ao outro tem, como consequência, a debilitação do processo vital total". Para o autor, tomando como base o conceito nitzscheano,

Este equilíbrio necessário entre o apolíneo e o dionisíaco, através do qual e no qual a vida se manifesta, nos abre a possibilidade de compreendê-los, não mais simplesmente como dois movimentos distintos e opostos, mas como diferentes aspectos do mesmo vir-a-ser universal, que sempre suscitam e pressupõem um ao outro (Idem, p. 62, grifo do autor). 
Portanto, pode-se compreender o senhor Henri (TAVARES, 2004b) como uma representação da luta da força dionisíaca da poesia, da liberdade de transgredir, da música, das artes em geral, em oposição e confronto com a força apolínea, representada pelas ciências empíricas, pelo conhecimento formal, pelo arranjo ordenado e construtivo das coisas, ou seja, estes últimos constituindo elementos ligados ao princípio de construção e multiplicação do devir, refletido na organização sistemática e intencional do saber organizado e metódico.

Assim, a personagem representaria, simbolicamente, 0 ponto de encontro e luta entre as duas tensões, com prevalência do polo dionisíaco, em que o desregramento representado pelo uso abusivo do absinto é a causa provável do seu pseudofilosofar, em confronto com a força apolínea, figurativizada pelo saber sistematizado, que ele também verbaliza, ainda que de forma rasurada.

Geralmente, no bar/sala de visitas, ao fazer menção a dados supostamente extraídos da enciclopédia, a personagem elabora e expressa 0 seu conhecimento, ainda que distorcido, emergindo aí a força apolínea, representativa da multiplicidade e da ordenação, em que o conhecimento, ainda que de caráter enciclopédico, é fator construtivo e gerador. A personagem é, portanto, e concomitantemente, o terreno em que se digladiam as duas forças de que fala Nietzsche (BENCHIMOL, 2003).

O senhor Henri, bem como os demais senhores, levam vidas marcadas pelo individualismo, vivendo distanciados do convívio comunitário e integrado do assim denominado O Bairro.

De acordo com a classificação cronotópica proposta por Bakhtin (1988, p. 321-322), é possível identificar um importante período, no qual a vida coletiva, eminentemente agrícola e atinente às fases da existência das pessoas se individualizou.

Segundo o teórico russo, a marca de diferença que incidiu sobre esse cronotopo ocorreu à medida que a sociedade se estratificou em classes e as esferas ideológicas se modificaram gradativamente. Deu-se, então, uma desintegração da vida coletiva, migrando os aspectos comunitários para a vida 
cotidiana de caráter mais individualizado, como é o caso da comida, da bebida, da vida sexual e da morte. Assim, a vida dos senhores na contemporaneidade é marcada por essa mesma característica de individualização, estando perdidas as práticas coletivas que marcaram, em épocas anteriores, o fazer humano.

A diferenciação de que fala Bakhtin marca também o aparecimento da paródia, do riso, da bufonaria e da obscenidade rituais, que terão seu auge literário, mais tarde, com Rabelais. De acordo com Bakhtin,

\begin{abstract}
Nesse estágio [...], o escravo e o bufão transformam-se, na morte, nos substitutos do rei e do deus, onde aparecem as formas da paródia ritual, onde as paixões se misturam com 0 riso e a alegria. [...] as obscenidades proferidas durante um matrimônio e a ridicularização do noivo; a ridicularização ritual feita pelos soldados romanos do chefe militar triunfante entrando em Roma (trata-se da lógica da vítima postiça: esconjurar a verdadeira desonra por uma desonra fictícia; posteriormente, será interpretada como uma garantia contra a inveja do destino (Idem, p. 322, grifo do autor, sublinhado nosso).
\end{abstract}

Para o autor, quanto mais se desenvolve a sociedade de classes, e se acentuam as diferenças entre as esferas ideológicas, mais se desintegram os elementos da vizinhança, como a comida, a bebida e o ato sexual, que são absorvidos, pouco a pouco, pela vida cotidiana e privada, tornando-se problemas pessoais e familiares, pequenas realidades ordinárias do dia-a-dia.

Tais mudanças, segundo Bakhtin (Ibid., p. 322-323), refletir-se-ão de forma contundente na literatura e nas ideologias, espalhando-se os elementos da vizinhança por diversos planos, gêneros, tons e estilos, ficando, por exemplo, a sexualidade, banida dos gêneros e discursos oficiais das classes privilegiadas, o que cria novas ligações e vizinhanças, as quais, por sua vez, também afetam outros aspectos da vida cotidiana, como o casamento, a família e a procriação. 
A comida e a bebida restam, então, relegadas a gêneros médios e baixos, de caráter semi-oficial, como um apêndice secundário da vida privada. Do mesmo modo, rompe-se a ligação da morte com o riso, o sexo e a paródia, adquirindo as novas ligações, muitas vezes, caráter metafórico. Todos os aspectos mencionados marcam, por conseguinte, uma cisão no tempo concreto da vida humana, por meio da qual ficam separadas as séries dos destinos individuais do tempo da vida coletiva.

Essa mudança de perspectiva ensejou a que o homem tivesse maior nitidez de sua própria imagem, do modo como via a si mesmo e agia no seu entorno, com reflexos nos motivos, na organização temporal e no desdobrar do enredo.

No caso da obra de Tavares, todos os referenciais da vida são eminentemente individuais. O ser coletivo, a comunidade, as relações interpessoais não têm espaço frente às idiossincrasias e peculiaridades de cada um dos senhores. O que se denomina $O$ Bairro não representa um centro de vida comunitária, mas a compartimentalização de indivíduos incomunicáveis, os quais habitam prédios fisicamente contíguos, com janelas mínimas, metáforas do distanciamento a que estão submetidos, presos em seus universos específicos e sobre os quais nem sempre exercem crítica, como é o caso do senhor Henri, o qual, ainda que apresente elementos de desregramento, próprios do cronotopo rabelaisiano, vive uma vida individualizada, sem conexões interpessoais.

O cronotopo do bar/sala de visitas, freqüentado pelo senhor Henri, é um lugar para beber apenas, e não para a troca de experiências entre pessoas que se conhecem e se reúnem para partilhar conversas. Quando discursa no bar, o senhor Henri possivelmente fala para si mesmo, já que não há evidência de interlocução ou compartilhamento de ideias.

Para Bakhtin, anteriormente à mencionada desintegração da vida coletiva, e em contraste com o modo isolado em que vivem os senhores, a unidade total do tempo englobava todo o viver humano, comunitária e individualmente, fundindo-se os aspectos interiores com os exteriores. 
No caso do senhor Henri, o bar/sala de visitas se contitui como o palco de exibição dos seus "conhecimentos", em que ele afirma, por exemplo, que "o arco-íris foi inventado em 1656" (TAVARES, 2004b, p. 55), para corrigir-se logo em seguida: "... estou a brincar, é claro. ... a diferença entre os assuntos da natureza e os assuntos do homem é que os assuntos da natureza não têm data de invenção - disse. ... os assuntos da natureza são sempre mais antigos. ... um copo de absinto, por favor - pediu" (Idem, p. 55).

Assim, o cronotopo da sala de visitas em 0 senhor Henri é tanto o tempo/espaço da tensão como do divertimento, este último ocorrendo com maior frequência. Por ser praticamente impossível para este senhor privar-se de sua bebida preferida, certo dia, ele afirma no bar: "[...] hoje não vou tocar num copo. ... haverá, então, alguém disponível para me despejar absinto pela garganta? ... estou a brincar - disse o senhor Henri. ... metade do prazer de beber absinto está em pegar no copo. ... metade talvez seja um exagero. ... quero um copo cheio de absinto até aos miolos, e já [...]" (Ibid., p. 61).

Do seu ponto de vista, e como se estivesse a discursar para um grande público, constituído pelos frequentadores do bar, ele afirma:

[...] se um homem misturar absinto com a realidade obtém uma realidade melhor. ... podem crer, excelentíssimos ouvintes, que vos falo, não por via de uma erudição, que sem dúvida alguma possuo em grandes quantidades; mas não, não é por aí que a minha voz vem. ... a minha voz vem da experiência, caros concidadãos! ... é verdade que se um homem misturar absinto com a realidade fica com uma realidade melhor. ... mas também é certo que se um homem misturar absinto com a realidade fica com um absinto pior. ... muito cedo tomei as opções essenciais que há a tomar na vida - disse o senhor Henri. ... nunca misturei o absinto com a realidade para não piorar a qualidade do absinto (Ibid., p. 65-66).

O discurso deste senhor é invariavelmente voltado para duas vertentes: os conteúdos que lê na enciclopédia e o absinto, já que não possui assuntos cotidianos ou familiares sobre os quais falar. Quando não discursa sobre seus conhecimentos enciclopédicos ou fala da importância do absinto, ele se elogia 
e/ou dirige imprecações aos mais próximos, em uma retomada do cronotopo rabelaisiano. Assim, em "O espirro", ele dispara sua verborragia, passando do discurso "sério" sobre os Lapões, passando pelas moscas e por Pilatos, chegando, finalmente, às ofensas:

[...]... os Lapões acreditavam que um espirro forte pode matar a pessoa que dá o espirro, mas se vissem o espirro que vossa excelência acabou de proferir, julgo que eles mudariam de opinião. ... um espirro desses pode matar os outros. [...]. ... um espirro dessa dimensão é pior que a maldição proferida por uma bruxa. ... esse espirro deve ter mais doenças que um catálogo de médicos. [...]. ... um espirro desses só pode vir de um iletrado e de um analfabeto, de um parasita da sociedade que escolhe honrados locais para introduzir o seu poderoso veneno, e assim lentamente derrubar o sólido edifício que constitui a nossa sociedade (Ibid., p. 90-91, sublinhado nosso).

Disso se depreende que o senhor Henri não tem assuntos cotidianos e comuns a tratar por falta de reais interlocutores, alguém de convivência contínua. É impossível para ele comentar algo sem relação com o absinto ou a enciclopédia. Assim, uma única vez, o narrador onisciente o descreve indo encontrar-se com um amigo, perdido com relação ao tempo:

O senhor Henri, entretanto, estava baralhado com as horas. Pensava que eram quatro da tarde e, afinal, eram só onze da manhã. Cheio de pressa, porque tinha combinado encontrar-se com um amigo às quatro e meia, o senhor Henri repetia, acompanhando o passo acelerado: 600 anos antes de Cristo!, [...]. Temos de ser exactos nas datas, disse o senhor Henri, enquanto equivocado, pensando estar atrasadíssimo, continuava a acelerar o passo (Ibid., p. 19-20, sublinhado nosso).

O mundo apartado da realidade em que vive o senhor Henri o impede até mesmo de saber as horas do dia, preso que está, inexoravelmente, a referências temporais deslocadas do tempo/espaço circundante. Ao apressar- 
se para encontrar um amigo, ele não percebe que está na verdade adiantado, manifestando, paradoxalmente, o gosto pela precisão de datas.

Tal fato remete à questão do deslocamento ou "desencaixe" do homem contemporâneo, segundo Anthony Giddens (2002, p. 10), vítima da separação de tempo e espaço, que conspira para a falta de referenciais sólidos a balizar o cotidiano de um tempo que se caracteriza hoje como uma grandeza em um processo de aceleração contínua.

Como personagem da contemporaneidade, o senhor Henri tem controle sobre poucas coisas: as idas ao bar, a ingestão irrefreada de absinto, a verborragia enciclopédica. O Outro é uma ausência permanente em sua vida, que precisa ser preenchida por excessos em outras áreas. Como um outsider do mundo contemporâneo globalizado, o senhor Henri e os demais senhores abrem, a custo, um espaço de conforto precário, que não oferece horizonte possível de satisfação consistente e de longo prazo. Segundo Giddens (Idem, p. 185), o narcisismo, tal como pode ser apreciado na personagem, constitui um "primeiro tipo de patologia de comportamento associado às influências mercantilizantes" do mundo contemporâneo.

De acordo com o autor,

Todo autodesenvolvimento depende do domínio sobre as respostas apropriadas aos outros; um indivíduo que necessita ser "diferente" de todos os outros não tem chance de desenvolver reflexivamente uma autoidentidade coerente. A personalização excessiva tem ligações com concepções de grandiosidade. O indivíduo é incapaz de descobrir uma autoidentidade suficientemente "sóbria" para conformar-se às expectativas dos outros em ambientes sociais (Ibid., p. 185, grifo do autor, sublinhado nosso).

Os contatos do senhor Henri com o mundo externo são, pois, eventuais, constituindo rasuras paródicas à história e à ciência. Tal pode ser observado certo dia, em que ele aguarda um eclipse anunciado como manifestação de um fenômeno natural: 
Depois de beber umas boas goladas o senhor Henri disse: que belo eclipse! [...]. Deitado no chão à espera que algo acontecesse no céu o senhor Henri acabou por fechar os olhos e adormecer. Quando acordou pegou na sua mochila e na sua garrafa de absinto e retirou-se. Tive um eclipse privado, [...], satisfeitíssimo com os astros que conseguira ver no seu céu particular (TAVARES, 2004b, p. 31-32).

Em outros momentos, talvez impulsionado pelo absinto, este senhor dirige, sem falsa modéstia, vários elogios à sua inteligência: “[...] ... e vossas excelências reflictam bem no que o senhor Henri vos está a dizer, que o senhor Henri é muito cerebral" (Idem, p. 67). Em outros momentos, sem qualquer razão aparente, ele rebaixa a dos demais: "[...] ... eu não sou um intelectual, mas poderia ser - [...]. ... eu tenho mais raciocínio que fisiologia, caros amigos. E basta olhar um segundo para as vossas caras para perceber que o mesmo não se passa convosco" (Ibid., p. 78-79).

Ele, então, prossegue hiperbolicamente em relação a si próprio, desmerecendo, por oposição, os demais presentes: “[...] ... espero que não se ofendam, mas a verdade é que os vossos rostos, caríssimos amigos, são puramente fisiológicos. [...]. ... enquanto o meu rosto, [...] é um pouco de fisiologia e um pouco de nariz, é certo, mas é principalmente uma máquina de raciocínio, um animal do pensamento, uma indústria filosófica. [...]. Vossas excelências cheiram até a fisiologia [...]" (Ibid., p. 79).

Quanto à carência afetiva desse senhor, há que se notar que ele, em dado momento, sente falta da presença de mulheres no cronotopo do bar. Entre as causas possíveis, verbalizadas pela própria personagem, estariam as péssimas condições de higiene do local, não constituindo o bar, portanto, um ambiente propício à presença feminina:

[...] ... senhor director, caro director, excelentíssimo excelente director: como é possível um estabelecimento com esta qualidade de paredes e de fungos, com esta qualidade de doenças potenciais devido por um lado ao não tratamento correcto da canalização, à humidade (sic) que aqui reina, e aos cheiros maus e maléficos e putrefactos. Em suma: como é 
possível em tal reino não existir uma única mulher bela para compensar[?] (Ibid., p. 81, sublinhado nosso).

Em seguida, e em oposição à sua fala anterior, o senhor Henri desvia o seu discurso em direção ao rebaixamento das mulheres no que se refere ao serviço que prestam aos homens, repudiando, paradoxalmente, a presença feminina no bar:

[...]. ... a mulher é a mais inútil das ferramentas do homem porque a mulher é uma coisa bela. ... mas caro comendadordiplomata, no dia em que uma mulher puser um único pé neste seu átrio para visitas excelentíssimas, eu, aqui, o vosso sempre disponível senhor Henri, não colocarei, por sua vez, isto é: por minha vez, um único outro pé dos meus, neste tão honroso átrio para visitas excelentíssimas! ... porque as mulheres dão mais azar que uma garrafa vazia na despensa (Ibid., p. 82, sublinhado nosso).

O tratamento cerimonioso da personagem em relação ao dono do bar ocorre paralelamente ao aumento progressivo dos enaltecimentos que faz à sua pessoa e das falsas adulações dirigidas aos demais clientes do estabelecimento, refletidas nos solenes pronomes de tratamento. Uma das possíveis razões para tal seria o grau de embriaguez em que ele se encontra desde o início, e que vai gradualmente aumentando, assim como crescem o número e a extensão das suas falas, da impaciência, dos xingamentos, das grosserias, das teorias e das manifestações de pseudossaber.

Dessa forma, ele reforça os elogios, assim como as injúrias, a partir de certo ponto da narrativa. Nas citações abaixo, os sublinhados são nossos:

"[...] ... um copo de absinto, excelentíssimo imperador - pediu o senhor Henri" (p. 69);

"[...] Sabem vossas excelências quem era Pilatos [?]" (p. 89);

"[...] ... um copo de absinto, senhor embaixador" (p. 85). 
A relação do senhor Henri com o mundo consiste, pois, em proferir elogios e/ou injúrias; em discursar para uma plateia de improváveis ouvintes no cronotopo do bar/sala de visitas; em absorver informações da enciclopédia, que são depois adaptadas segundo a conveniência do momento; em louvar o absinto e fazer dele amplo uso todos os dias.

Esses meios são empregados como tentativas de aproximação e organização do mundo, funcionando o álcool como uma espécie de "amortecedor" para o sofrimento, liberando-o para dizer e fazer coisas que não ousaria, caso estivesse sóbrio.

Pode-se notar, no tempo/espaço do bar/sala de visitas, seu refúgio e forma de ancoragem a um referencial concreto, que há outro aspecto a conectar o senhor Henri ao cronotopo de Rabelais, segundo a descrição de Mikhail Bakhtin. $O$ absinto funcionaria aí de modo semelhante ao que se dá com as personagens de Rabelais em relação à comida e à bebida, especialmente no que se refere ao fenômeno que Bakhtin denomina de "pantagruelismo" (1988, p. 299).

No caso do senhor Henri, poder-se-ia falar de um "pantagruelismo etílico", circunstância na qual a sua "sabedoria", alegria e disposição para falar em público seriam provavelmente motivadas pela ingestão da bebida. Para 0 teórico russo,

O "pantagruelismo" é a arte de ser alegre, sábio e bom. Por isso o saber festejar de forma alegre e sábia constitui a própria essência do pantagruelismo. [...]. Assim, também a série da comida e da bebida, no seu desenvolvimento grotesco, concorre para a destruição das velhas e mentirosas contiguidades entre as coisas e os fenômenos, e à criação de novas contiguidades que tornam o mundo compacto e materializado (Idem, p. 299-300, grifo do autor, sublinhado nosso).

A questão das contiguidades mencionadas pelo teórico russo pode ser também aplicada, com adaptações, ao senhor Henri. Para a personagem de Gonçalo M. Tavares há a disposição contígua de elementos aparentemente 
díspares, como é o caso dos dados enciclopédicos. Esses constituem uma forma de organização e referenciação de mundo, levando-se em conta ou não os efeitos do álcool por ele ingerido.

Uma dessas contiguidades consiste na associação de uma palavra em um contexto aparentemente histórico com o seu suposto significado em chinês, o que o leva a outra história que não guarda relação com a anterior.

Outro exemplo de contiguidade, dentro da lógica do senhor Henri, é também a menção, pelo narrador onisciente, do aparente atraso quanto ao horário de encontro com um amigo, paralelamente ao fato dos babilônios terem um calendário desde o ano 530 a.C.. (TAVARES, 2004b, p. 19). A associação têmporo-analógica, que se estabelece entre o dado enciclopédico e o horário do relógio, gera uma contiguidade por associação indireta entre elementos improváveis do ponto de vista da lógica formal, mas que, entretanto, estão ligados a grandezas de tempo.

Para Mikhail Bakhtin (1988, p. 305), a contiguidade consiste em aproximar elementos que normalmente não estariam próximos, e que na literatura de Rabelais se aproximam e se tocam, funcionando este processo também em sentido inverso, isto é, distanciando e separando elementos que deveriam estar juntos. Ao mencionar as séries que aparecem na obra rabelaisiana, Bakhtin afirma, ainda, que "Todas estas séries (comida e bebida, vestuário, excrementos, morte, utensílios domésticos, a série zoológica), que gravitam ao redor do homem carnal, assumem as mesmas funções de desunir o que era tradicionalmente unido, e aproximar o que (estava) hierarquicamente separado" (Idem, p. 305).

Para o teórico, o conceito de contiguidade pode igualmente reposicionar, elementos opostos, como vida e morte, já que, no mundo medieval, a visão da morte encontrava-se no limite entre a vida provisória e perecível e a vida eterna na concepção medieval, tendo Rabelais recolocado a morte em seu novo lugar no mundo, tal qual ele é, com suas características de mundo real. Assim, segundo o autor:

Destruindo o quadro hierárquico do mundo e construindo um novo no seu lugar, Rabelais deveria reconsiderar também a 
morte, colocá-la no seu lugar no mundo real e, antes de tudo, mostrá-la como um elemento indispensável da própria vida, mostrá-la na série temporal da vida que engloba tudo, que caminha para a frente, não tropeça na morte e não despenca nos abismos do além, mas permanece toda aqui, neste tempo e espaço, sob este sol [...] (Ibid., p. 306, grifo do autor, sublinhado nosso).

Bakhtin oferece ainda um exemplo de uma das contiguidades possíveis, ao falar da série da morte ligada à série da comida, dentro do contexto do cronotopo rabelaisiano: "A imagem anatômico-fisiológica da morte está inserida no quadro dinâmico da luta dos corpos humanos e finalmente é apresentada em vizinhança direta com a comida - 'expirou a alma junto com a sopa"”12 (Ibid., p. 306, grifo do autor).

Ainda com referência ao cronotopo de Rabelais, há o intuito explícito de expor as mazelas do status quo do período medieval e do início do Renascimento, estando os indivíduos denunciadores escondidos atrás de máscaras. Já o senhor Henri, personagem de feitio essencialmente carnavalizado, faz do bar a sua praça pública, elogiando e ofendendo com a mesma liberdade e intensidade, sem estar velado por qualquer máscara. Ao chamar os frequentadores e balconistas do bar por pronomes de tratamento solenes, ele enaltece os que lá estão e rebaixa aqueles que poderiam ser assim chamados, por sua cultura ou títulos, rasurando os que seriam supostamente considerados "modelos" da sociedade.

Rabelais opera com sua obra, de fato, como que um desmascaramento do establishment. Por trás da máscara, o homem, como tal, não se revela em sua essência individualizada, mas expõe todo o seu aspecto alegórico, participando do desmascaramento da vida como juiz, investigador, político, religioso, bufão, etc., de modo a denunciar tudo o que é falso, convencional e pernicioso nas relações humanas. Para Bakhtin,

\footnotetext{
${ }^{12}$ RABELAIS, F. Gargantua, cap. XXXV apud BAKHTIN, 1988, p. 306, a partir do original em francês: "[...] et l'ame meslée parmy les souppes".
} 
A hipocrisia e a impostura impregnaram todas as relações humanas. As funções naturais oriundas da natureza humana realizam-se, por assim dizer, pelo contrabando selvagem, porque a ideologia não as consagra. Isto introduzia a falsidade e a duplicidade em toda a existência do homem. Todas as formas ideológico-institucionais tornavam-se hipócritas e falsas, enquanto que a vida real, privada de interpretação ideológica, tornava-se grosseiramente animal (Ibid., p. 278, grifo do autor, sublinhado nosso).

Tais máscaras praticamente davam o direito de imitar, parodiar, emular, não compreender, confundir e hiperbolizar aspectos da vida e do comportamento humano. De acordo com Bakhtin, (Ibid., p. 279), essas máscaras conferiam igualmente o direito de falar de maneira paródica, invertida, não literal, isto é, não sendo o próprio indivíduo, mas aproximando-se dele o mais possível de modo a expô-lo em sua crueza e em seu ridículo. É como se a vida fosse conduzida pelo cronotopo intermediário dos palcos teatrais, sendo a própria vida uma comédia, e as pessoas, seus atores, indivíduos que, despidos de suas fantasias e disfarces, revelam sua vida privada e seus segredos íntimos e sórdidos.

O primeiro aspecto da importância das figuras do bufão do bobo e do trapaceiro na literatura de Rabelais relaciona-se à sua ligação com o teatro propriamente e com o teatro de máscaras ao ar livre, o que as conecta diretamente com a praça pública e com todos os elementos carnavalescos fundamentais aí contidos. Outra característica relevante concerne à própria existência de tais personagens em seu âmbito figurado, isto é, tudo o que dizem e fazem, além da sua própria aparência, não tem sentido imediato, mas remete ao ambivalente e, muitas vezes, ao invertido. Não há como interpretálas literalmente; sua existência depende e é reflexo indireto de outra.

Sendo personagens estrangeiras nesse mundo, segundo Bakhtin (Ibid., p. 276, grifo do autor), elas não apresentam empatia com nada referente a ele. Seu único papel é revelar o avesso e o falso contido em cada situação a que estão relacionadas. Elas, ao mesmo tempo, riem e são objetos de riso dentro do caráter público da praça popular, expondo seu único lado crível e 
exclusivamente externo: elas vivem apenas a existência do outro e somente do lado de fora, o da praça, estabelecendo um modo especial de exteriorização do homem, que é o do riso paródico (Ibid., p. 277).

Ainda segundo o teórico, com relação ao romance, também o autor necessita de uma máscara capaz de determinar sua visão de mundo, seus posicionamentos em relação à vida e à maneira como ele exterioriza na obra suas posições. Desse modo, o cronotopo da praça pública se torna extremamente relevante para o gênero romanesco, revelando formas de ser do homem como um participante da vida que, graças às máscaras, não toma parte dela, sendo, portanto, simultaneamente, seu observador e refletor, ao deixar à mostra esferas da vida que são essencialmente privadas, como por exemplo, a da vida sexual (Ibid., p. 278), e que nos senhores aparece de forma velada e eminentemente platônica. Outros aspectos críticos são mais contundentes, especialmente aqueles relacionados às condições estatutárias do homem no âmbito social.

Os Senhores, de Gonçalo M. Tavares, representam, de certo modo e por suas particularidades e idiossincrasias, bufões, bobos e trapaceiros, só que sem as máscaras. O avesso não tem o sentido de denúncia, mas de assunção de uma postura que revela a personagem tal qual ela é. A crítica e a denúncia, possivelmente intentadas pelo autor na obra, cabem ao analista identificar e interpretar. $\mathrm{O}$ universo de fantasia e absurdo em que habitam as personagens não é um disfarce em um tempo de exceção, mas o cotidiano invertido em que se inserem, não se podendo excluir aí o olhar crítico do autor em relação a uma sociedade eminentemente excludente e fragmentada.

É como se os senhores existissem em função dos seus próprios cronotopos, ou seja, seus modos de ser, suas ações, falas e pensamentos são regidos pelo tempo/espaço que as enforma, isto é, elas se constituem como produto dos seus cronotopos. Há, nesse caso, como que uma fusão entre personagem e cronotopo, que resulta em uma espécie de amálgama têmporoespacial, do qual resulta a imagem da personagem. Nessa acepção, um elemento não pode existir sem o outro e só existe por meio do outro, ambos determinantes e determinados por tempo e espaço próprios. 
O espirro criticado pelo senhor Henri figurativiza uma das muitas formas de agressão e invasão, entre aquelas impostas pela sociedade e pelo sistema ao homem da pós-modernidade, e que encontra revide por meio da indignação da personagem, que prossegue com os xingamentos $e$ as pontuações concernentes aos riscos patológicos potenciais causados pelos espirros, mesclados às demonstrações de pseudoerudição medieval do senhor Henri. As críticas aos políticos e ao sistema não encontram eco, diante de um interlocutor que só ouve e nunca responde às ofensas crescentes, funcionando aí o espirro como um elemento agressivo e intruso, sujo e com potencial contaminante":

[...] ... fique vossa excelência a saber que vou já beber outro copo de absinto para queimar todos esses demónios que vossa excelência com esse espirro-canhão atirou contra nós, sem qualquer piedade, como um carrasco da Idade Média. ... sabe que na Idade Média os carrascos utilizavam máscaras para não serem mais tarde reconhecidos, e para ninguém se vingar deles? E sabe que nos tempos que correm os carrascos já não precisam de máscaras, e recebem ainda um ordenado fixo do Estado? ... vossa excelência deveria saber que este Estado é a maior vergonha para 0 nosso, já que não protege estabelecimentos como este, que difundem a cultura por todo o corpo como um bom copo de absinto faz[!] (TAVARES, 2004b, p. 92, sublinhado nosso).

A peroração do discurso ofensivo mistura religião, história, ciência e etiqueta, entremeada de outros xingamentos, culminando, paradoxalmente, com uma advertência ao cliente causador do espirro, e que está provavelmente resfriado: "[...] ... vossa excelência é uma besta, e com esta me fico. ... uma besta, é o que é. ... e amanhã não se esqueça do guarda-chuva que vai chover (Idem, p. 93).

Outra personagem que apresenta transformação ao final da narrativa, além do já mencionado senhor Breton, é o senhor Henri, o qual, depois de ofender longamente o frequentador do bar que ousou espirrar, decide não mais falar, limitando-se a apenas pedir a bebida. Dessa maneira, depois de tantos discursos proferidos no bar, expressando seus conhecimentos enciclopédicos e 
proferindo suas ofensas, ele resolve silenciar, já que seus conhecimentos não são valorizados pelos ouvintes, contentando-se ele em se restringir apenas ao essencial:

Depois de um prolongado silêncio, o senhor Henri disse: hoje vou entrar e sair sem proferir uma única palavra. ... a partir de hoje vou reduzir o meu discurso ao essencial, visto notar que neste estabelecimento não dão o devido valor às minhas dissertações enciclopédicas. ... a partir de hoje só abrirei a boca para pedir mais absinto, e sobre o resto ninguém me ouvirá mais nada, porque, no fundo, vossas excelências são um conjunto de bêbados (Ibid., p. 97, sublinhado nosso).

Embora se possa afirmar que a transformação do senhor Breton é mais profunda, no caso do senhor Henri é possível concluir que, no confronto das esferas dionisíaca e apolínea que se digladiam na vida deste senhor, há, ao final da narrativa, a prevalência da primeira, representada pelo cronotopo do bar e pelo desregramento causado pela bebida, embora ele próprio, ironicamente, não se julgue um bêbado.

Assim, o cronotopo do bar, tempo/lugar de Baco ou Dionísio, e que constitui o cronotopo da sala de visitas do senhor Henri, representa, de maneira contundente, as forças de dissolução, desconexão e aniquilamento, segundo o conceito nietzscheano expresso por Benchimol (2003). O senhor Henri seria, nesse caso, a representação do que o autor alemão designou originalmente como "[...] ente isolado como indivíduo que quer e promove seus escopos egoísticos" ${ }^{\prime 3}$ (BENCHIMOL, 2003, p. 59, grifo do autor).

Assim, o "essencial" a que se refere o senhor Henri é, pois, figurativizado pelo caos e pela transgressão simbolizados pelo álcool, circunstância em que a luta entre os dois pólos opostos aparentemente termina com a vitória da força dionisíaca, e, portanto, com a opção da personagem pelo que é pertinente ao próprio cronotopo do bar, palco da dissipação e do desregramento. O pedido de bebida, ao final do último parágrafo da narrativa, consiste na suposta

\footnotetext{
${ }^{13}$ GT, 5, KSA, Band I, p. 47. Tradução de J. Guinsburg. In: 0 nascimento da tragédia. São Paulo: Cia. das Letras, 1992, p. 47.
} 
decisão da personagem: "[...] ... a partir de hoje só mesmo o essencial. ... e de informações fico-me por esta. ... mais um copo de absinto, excelência - disse o senhor Henri" (TAVARES, 2004b, p. 97).

É explicável que, depois de tantas ofensas e esconjurações dirigidas ao pobre diabo que ousou espirrar, um esgotado senhor Henri esteja propenso a falar menos e a apenas beber. $O$ "essencial" a que ele se refere diz respeito ao aspecto dionisíaco da sua vida, isto é, suas idas habituais ao bar e a ingestão sistemática do absinto. A negação aparente do aspecto apolíneo, com sua recusa em manifestar seu saber enciclopédico, não pode ser tomada como decisão irrevogável, em se tratando do senhor Henri, especialmente após a ingestão de alguns copos de absinto.

Nesse sentido, a narrativa recupera apenas a ideia de transformação e não de metamorfose do romance grego do segundo tipo, o de aventuras e costumes, segundo Bakhtin (1988, p. 234), em que a personagem, tendo passado por provações e induzida a refletir, de algum modo, se vê transformada.

O fato de o senhor Henri não ser ouvido pelos frequentadores do bar, acrescido à injúria representada pelo espirro, o levam à decisão de eliminar o que se poderia chamar de apolíneo - seu conhecimento enciclopédico, que emula a noção de ordenamento e multiplicação, própria do que é "de Apolo", de modo apenas aproximado, e com diferenças assinaláveis. Observa-se aí a metamorfose do romance grego, que supõe mudança física e psicológicoemocional da personagem em seu aspecto identitário, ao passo que a transformação, nos casos dos senhores Breton e Henri não se dá em nível tão profundo como na metamorfose propriamente dita.

No caso de Lúcio, a refutação se dá por via inversa: as provações pelas quais passou o conduzem de volta ao estado humano, no qual o regramento $e$ a ordenação prevalecem, segundo a sua própria natureza de homem. A transformação em asno rompe com o ordenamento anterior, com prevalência da desordenação própria do que é "de Baco ou Dionísio", o que acaba por trazer à personagem de Apuleio mais desvantagens e provações do que benefícios, o que a faz percorrer o trajeto inicial do apolíneo ao dionisíaco, 
retornando finalmente ao apolíneo, que reorganiza a sua essência e característica humanas.

O senhor Juarroz, por sua vez, de todos os senhores é o que mantém menor nível de contato com o Outro e com o mundo exterior em geral. Ele vive em seus pensamentos - o que configuraria um cronotopo da vida interior estabelecendo consigo mesmo diálogos e reflexões. Quando ele e sua esposa conversam, configura-se o tempo/espaço da sala de visitas, e, portanto, do conflito, já que ela se coloca em frontal oposição às idiossincrasias do cônjuge.

Uma delas reside no fato de que o senhor Juarroz insiste em reservar uma gaveta da casa "para guardar o vazio" (TAVARES, 2007a, p. 13), contrariando a opinião da esposa, que acha um desperdício de espaço ter uma gaveta vazia. Ao instar com o marido para que ele a ocupe, o senhor Juarroz explica: "Ainda não está totalmente vazia. Ainda falta" (Idem, p. 14), ao que a esposa responde: "Esperamos, então, mais um mês - murmurava, resignada, a paciente esposa do senhor Juarroz" (Ibid., p. 14).

O consultório médico também aparece na narrativa como o cronotopo da sala de visitas, em que se estabelece o embate da personagem com o seu médico. Além de falar com o profissional, o senhor Juarroz prossegue em seu diálogo interior ininterrupto. Nessa circunstância, o espaço que é inicialmente de tensão, ameniza-se ao final:

Medir um organismo - pensava o senhor Juarroz - é aceitar uma mentira, pois um organismo, por definição, não tem comprimento, tem fome. Como medir algo que está a mudar? Como medir uma mudança? - pensava o senhor Juarroz. $\underline{0}$ médico à sua frente, no entanto, estava prestes a desistir. Afinal, posso pesá-lo ou não? Pese-me apenas quando eu acabar de mudar - estava prestes a dizer o senhor Juarroz. Porém, pensou de imediato que nessa altura talvez fosse demasiado tarde para a medicina atuar. Faça favor, faça favor - disse o senhor Juarroz, por fim, com uma delicadeza extrema (Ibid., p. 45, sublinhado nosso). 
O mundo interior do senhor Juarroz, que é o tempo/espaço onde ele permanece a maior parte do tempo, também equivale, algumas vezes, ao cronotopo da sala de visitas, por ser também palco de tensão, já que a personagem, por vezes, se torna seu próprio antagonista.

Por exemplo, ao tentar viajar, ele quer levar tantas coisas que sua mala fica muito pesada, o que impede a viagem: "E tal viagem tornava-se, então, desnecessária pois o senhor Juarroz estava já, observando bem, em sua própria casa" (Ibid., p. 25). Tomando medida oposta, ele decide viajar sem levar nada, enfrentando agora a possibilidade de passar frio, fome, e de sofrer outras necessidades: "Decidia sempre, por isso, à última hora, permanecer em casa" (Ibid., p. 26).

Sua total incapacidade para se relacionar e interagir com o Outro cria o já mencionado cronotopo da vida interior, no qual ele é o seu próprio interlocutor. Neste tempo/espaço, seu isolamento do mundo envolve todos os sentidos:

Assim, com os olhos, o nariz e os ouvidos tapados o senhor Juarroz podia pensar à vontade, sem qualquer interferência do exterior. Antes de entrar por completo nos seus pensamentos, o senhor Juarroz dizia ainda, para quem o quisesse ouvir: Agora, por favor, não se aproximem de mim. Acima de tudo não me toquem. Não estraguem tudo. E com a venda nos olhos, o algodão nos ouvidos, e a mola no nariz, o senhor Juarroz, tendo o cuidado de manter as mãos no ar para não tocar em nada, tinha então momentos de pura felicidade de pensamento (Ibid., p. 63, sublinhado nosso).

O cotidiano do senhor Juarroz, ainda que se passe em parte no cronotopo da sala de visitas, representado por sua casa, equivale também ao da pequena cidade, pela repetição cíclica de acontecimentos habituais: as discussões com a esposa, as insólitas manias em relação aos objetos que o rodeiam - tocá-los ou não, vê-los ou não, ouvi-los ou não, cheirá-los ou não enfim, toda uma rotina de recolher-se ao cronotopo do seu mundo interior com 
frequência, isolando-se do entorno, coloca também este senhor em um ciclo infindável de repetições e manias.

Certa feita, "Como gostava de ler e ia para uma viagem longa o senhor Juarroz decidiu pôr na mala seis exemplares do mesmo livro" (Ibid, p. 23). No caso não apenas desta viagem, como todas as outras planejadas por este senhor, não se realizam, já que ele sempre tenta levar na mala tantas coisas, que é como se levasse a casa toda, tornando a viagem desnecessária.

De modo semelhante ao senhor Breton, mas idiossincraticamente mais apartado do Outro, o senhor Juarroz é também o Outro de si mesmo, até em situações em que o Outro é imprescindível, como nas situações de jogo: "Como o senhor Juarroz não era muito adepto do desporto, optava por competir consigo próprio, através daquilo que ele designava como 'os seus dois jogadores': o pensamento e a escrita. Fazia, assim, jogos para verificar quem era mais criativo: se o seu pensamento, se a sua escrita" (Ibid., p. 49, grifo do autor).

Assim, às vezes,

[...] o senhor Juarroz ia às compras, não para comprar, mas para ver. Não ia fazer compras materiais, mas sim compras visuais. Como já o conheciam, os empregados do supermercado, vendo-o a entrar, por vezes diziam: Senhor Juarroz, olhe que chegaram uns produtos novos. Estão na última prateleira daquele corredor. E o senhor Juarroz, agradecendo a indicação, ansioso, lá acelerava o passo na direção indicada (Ibid., p. 51).

De modo análogo ao senhor Valéry, as conjeturas feitas pelo senhor Juarroz, suas hipóteses e teorias, convergem não apenas para o ilógico aparente, mas também encaminham seu raciocínio, que nem sempre conecta causa e consequência, no sentido de encontrar soluções:

A luz! A luz! Se existisse uma eletricidade para fazer aparecer o escuro como existe uma eletricidade para fazer aparecer a luz, o número de possibilidades duplicaria, mas também 
duplicaria a conta do mês. No entanto parece-me desagradável - pensava o senhor Juarroz - que baste desligar a luz para aparecer a escuridão. Para darmos a devida importância ao escuro - tanto, pelo menos, como damos à claridade - deveria ser necessário o ato de ligar a escuridão. Assim, quando se apagasse a luz, não surgiria logo o escuro, mas sim um qualquer estado intermediário. Só se dá importância ao que tem um custo: ligar a escuridão e pagar por ela, parece-me urgente - pensava o senhor Juarroz, um segundo antes de bater com o joelho contra uma mesa. Quem desligou a porcaria da luz?! - gritou, irritado, o senhor Juarroz (Ibid., p. 27, sublinhado nosso).

Tal como os senhores Breton e Calvino, que têm na janela, simbolicamente, a abertura para o mundo e o Outro, o senhor Juarroz oscila entre posições antagônicas: ver ou não ver o mundo lá fora, gostar de algo ou detestar, lembrar-se do que fez ou não. Assim,

Como era possível dentro de casa ouvir o silêncio, o senhor Juarroz abria a janela para entrarem ruídos, pois, no fundo, detestava o silêncio. Como as mãos eram, acima de tudo, máquinas de tocar nas coisas, o senhor Juarroz, quando ficava em casa em frente à janela aberta, gostava de encostar a sua mão esquerda ao vidro. Como uma das características mais entusiasmantes do ser humano era a capacidade de cheirar e saborear, o senhor Juarroz, quando ficava em casa com a janela aberta para ver e ouvir, com a mão direita encostada ao vidro para tocar, gostava ainda de beber um café bem quente e de cheiro intenso. [...]. [...] quando a sua esposa lhe perguntava o que vira e ouvira da janela, o senhor Juarroz não sabia o que responder porque não se lembrava de nada. E apenas uma chávena de café vazia provava algo: ele bebera, de fato, o café (Ibid., p. 29, sublinhado nosso).

É de notar que, ora ele toca o vidro da janela com a mão direita, ora com a esquerda, reforçando o processo de alternância e dualidade próprio do seu 
modo de ser, paralelamente ao fato de que sem poder tocar o Outro, é a janela que ele toca. Paradoxalmente, todo o aborrecimento que ele diz sentir em relação ao mundo exterior, se torna, repentina e inexplicavelmentemente, fonte de prazer.

Mais adiante, revelando sua ambivalência intrínseca, o senhor Juarroz age em sentido diametralmente oposto em relação à janela.

O senhor Juarroz por vezes punha uma venda nos olhos para
não ser distraído pelas formas e cores das coisas. Quando as
coisas além de existirem também faziam sons, o senhor
Juarroz, em apoio da venda, utilizava algodão nos ouvidos.
Porém, certas coisas, devido aos seus aromas fortes, insistiam
em infiltrar-se pelo nariz do senhor Juarroz, o que o levava, por
vezes, a tapá-lo com uma mola. [..... Como gosto do mundo,
murmurava (Ibid., p. 63 , sublinhado nosso).

Em certas ocasiões, ele é capaz de perceber tudo o que se passa ao seu redor. Em outros, não se lembra de nada. Vivendo a tensão do dualismo e da ambiguidade, o senhor Juarroz apresenta, por seu comportamento instável, uma tendência de mutabilidade, a qual também acomete o homem da época contemporânea, em que a transitoriedade de tendências e estilos de vida vai da moda à arquitetura, da arte aos meios de produção e consumo, de comportamentos a gostos adquiridos, passando por recomendações médicas e hábitos alimentares. O que é hoje de certa maneira, pode não sê-lo amanhã.

Quanto ao senhor Brecht (TAVARES, 2005), o cronotopo da sala de visitas corresponde a uma espécie de auditório em que ele narra suas histórias. No início, a plateia é quase inexistente: "Apesar de a sala estar praticamente vazia o senhor Brecht começou a contar as suas histórias" (Idem, p. 13).

A dificuldade de se relacionar o torna um narrador distante do eventual público ouvinte. Ele narra suas histórias como se as estivesse a ler em voz alta, para si mesmo a partir de um livro. Tal dificuldade pode ser especialmente notada ao final da última narrativa: "Depois de contar a última história o senhor Brecht olhou em seu redor. A sala estava cheia. As pessoas eram tantas que tapavam a porta. Como poderia agora sair dali[?]" (Ibid., p. 69). 
Sua angústia em se ver rodeado por tantas pessoas, e impossibilitado de retirar-se, revela seu medo da proximidade do Outro, que se configura aí como a alteridade incômoda. Os supostos ouvintes não estabelecem diálogo com o contador de histórias. Não perguntam, não opinam, não interagem: apenas ouvem as angustiantes e irônicas histórias, como a do filósofo que "[...] dizia que só os homens faziam o importante, enquanto os animais só dispunham de ações insignificantes. Foi então que chegou o tigre e devorou o filósofo, comprovando com os dentes a teoria anteriormente apresentada" (Ibid., p. 43).

Em O senhor Brecht, o cronotopo da sala de visitas é não apenas o tempo/espaço da tensão extrema, mas também o da crueldade, o que configuraria outro cronotopo, o do limiar, em que se decidem os destinos das personagens. Em "O amigo", o senhor Brecht narra a história de um rapaz tido como passivo por aceitar "[...] tudo o que vinha dos chefes" (Ibid., 47). Estes o consideram um bajulador e se sentem incomodados com isto, o que os leva a tomar, finalmente, uma decisão:

Cortaram-Ihe a língua: deixou de elogiar. Depois cortaram-lhe os dedos. Deixou de escrever textos laudatórios. Foi num desses dias que, com a cabeça a bater numa mesa - em código morse - ele disse, para os seus chefes: - Mais uma como esta e perdem um amigo (Ibid., p. 47).

Nas histórias do senhor Brecht, não há diálogo possível entre as personagens, à semelhança de um "vazio" de interlocução, seja por troca de opinião, convergência ou divergência de ideias. Há, apenas, tomadas de decisão unilaterais, com grande prejuízo para a parte mais fraca, representação do tempo/espaço do limiar, em que o Outro é objeto de repressão, mutilação e morte em todas as circunstâncias.

$\mathrm{Na}$ narrativa "O gatinho", à semelhança de uma fábula, a aparente tranquilidade da relação homem-animal de estimação leva o leitor a crer que, pela primeira vez, se poderá estabelecer aí um final ameno, o que é rapidamente contrariado pelo desenrolar da história: 
Havia um gato que todos os fins de tarde se aproximava do dono e Ihe lambia os sapatos com a sua língua minúscula. Vencendo uma certa timidez e uma certa precaução higiênica, o homem um dia decidiu descalçar-se para observar se o gato Ihe lambia os pés como fazia aos sapatos. Foi aí que o tigre, que se disfarçara de gato durante anos, decidiu que era o seu momento, e em vez de lamber, comeu (Ibid., p. 55).

Indivíduos sem identidade, as personagens das histórias do senhor Brecht como que se escondem por trás de máscaras, de modo que o homem, como tal, não se revela em sua essência individualizada, mas expõe todo o seu aspecto alegórico, participando do desmascaramento da vida, de modo a denunciar, segundo Bakhtin (1988, p. 278), tudo o que é falso, convencional e pernicioso nas relações humanas.

O cronotopo da sala de visitas, que, às vezes é sobrepujado pelo cronotopo do limiar, como o tempo/espaço das crises, é reforçado nas histórias do senhor Brecht, sempre de modo improvável. Em "O perigo da cultura", "Uma galinha pensava tanto e era tão culta que ganhou uma obstrução interior, deixando de por ovos. Mataram-na no dia seguinte" (TAVARES, 2005, p. 44).

Diante do incômodo representado por aquele que é "diferente", as decisões tomadas são extremas, colocando a vítima no limiar, na situação de tensão máxima e irreversível: a eliminação sumária do que não é capaz de cumprir o seu "dever", não importando quão inteligente seja.

As narrativas em $\mathbf{O}$ senhor Brecht mesclam os cronotopos da estrada, do encontro e da sala de visitas, além do tempo/espaço do limiar. A primeira narrativa, "Um país agradável", contraria já pelo título todo o desenrolar do enredo, revelando um nonsense intrínseco. De fato, no início,

Era um país muito agradável para viver, mas as pessoas eram tão preguiçosas que, quando o presidente ordenou que defendessem as fronteiras, eles bocejaram. Foram invadidos. Os invasores também começaram a ficar preguiçosos e, um dia, quando o novo presidente ordenou que os homens defendessem as fronteiras, todos bocejaram. Foram de novo 
invadidos. Agora por homens vindos de um outro país (Idem, p. 15).

Nesse "país agradável", onde a preguiça parece ser contagiosa, dá-se o encontro sucessivo de povos belicosos de vários países, já que se trata de invasões. Da beligerância explícita, os exércitos invasores passam para 0 extremo oposto, o da apatia, tal qual acontece com os habitantes nativos. $O$ cronotopo do encontro é aí denotativo do caos gerado por invasões de exércitos em sequência, os quais, também sucessivamente, caem em torpor. Pode-se entender aí a preguiça como índice de fraqueza de um povo em relação ao outro, relação em que o mais forte aproveita a situação de fragilidade do inimigo para exercer o domínio.

A culminância da narrativa tem lugar quando "[...] o novo presidente ordenou a invasão do resto do mundo pois o mundo estava completamente vazio - à sua mercê, portanto. Porém todos os homens bocejaram. E ele (sem o notar) avançou, sozinho" (Ibid., p. 15-16). Evidencia-se aí a ânsia pelo poder, ainda que seja a de um indivíduo contra um mundo vazio de habitantes, criando o inusitado e o aberrante próprios das narrativas de Gonçalo M. Tavares. Para Bakhtin,

Em qualquer encontro [...] a definição temporal ("num mesmo tempo") é inseparável da definição espacial ("num mesmo lugar"). [...]. A unidade indissolúvel (mas não a fusão das definições temporais e espaciais traz ao cronotopo do encontro caráter elementar, preciso, formal e quase matemático. Mas, naturalmente, esse é um caráter abstrato. Pois o motivo do encontro é impossível isoladamente: ele sempre entra como elemento constituinte da composição do enredo e da unidade concreta de toda a obra e, por conseguinte, inclui-se no cronotopo concreto que o engloba [...] (BAKHTIN, 1988, p. 222, grifo do autor, sublinhado nosso).

Dessa maneira, é possível compreender que as invasões sucessivas dos exércitos de países vizinhos ocorre contra o "país dos preguiçosos" devido à natureza dos habitantes, incapazes de defender as suas fronteiras em razão 
da indolência. Ao se tornarem, os próprios invasores, também preguiçosos, dão causa para que ocorram novas invasões, até que não resta mais ninguém no mundo. Assim, em uma sucessão causal, o enredo se estrutura e se desenrola, já que as determinantes de espaço e tempo continuam presentes, configurando ações iterativas.

Pode-se afirmar que o cronotopo do encontro trágico, associado ao cronotopo do limiar, são os mais frequentes nas narrativas do senhor Brecht, sinalizando o difícil e doloroso relacionamento entre as personagens, muitas vezes marcado pelo acaso, como acontece na história "O cantor". Trata-se do encontro fortuito entre pássaro e caçador, em que a ave é atingida sucessivamente na asa direita, depois na esquerda, na pata esquerda, e, mais tarde, na direita.

A cada tiro, o pássaro tem de adaptar sua maneira de voar, até perder totalmente a capacidade de fazê-lo. Assim, ao ser atingido pela primeira vez, o pássaro é forçado a voar na diagonal. Após o segundo tiro, ele se vê impossibilitado de voar, "[...] utilizando apenas as duas patas para andar no chão" (TAVARES, 2005, p. 19). Após ser alvejado na pata esquerda, ele passa a andar na diagonal e, finalmente, depois do tiro na pata direita, não pode mais andar.

Os sucessivos acontecimentos acabam por inutilizar completamente a ave, forçando-a a arranjar algo para fazer que não seja voar ou andar. Assim, "A partir desse momento dedicou-se às canções" (Idem, p. 19). Como em uma adaptação forçada, o pássaro figurativiza os ajustes de sobrevivência do homem contemporâneo, vítima de inúmeras injunções, casuais ou não.

O processo paulatino e compulsório de adaptação ao infortúnio, levado a efeito pelo pássaro, ocorre igualmente com o homem da contemporaneidade, que deve se adaptar forçosamente à violência cotidiana, segundo a qual, os mais fortes dominam os mais fracos. Longe de constituir consolo, a dedicação da ave às canções é a única saída possível para quem não tem outra opção que não aquela pertinente à sua própria natureza. Assim, o que é natural para um pássaro, ou seja, cantar, se torna seu último recurso de vida, dentro do inusitado narrativo em Os Senhores, de Gonçalo M. Tavares. 
Em geral, os encontros ocorridos nas histórias do senhor Brecht geralmente situam as personagens no cronotopo do limiar, que acaba por sobrepor-se ao primeiro, ou seja, o do encontro. Em "O vigia", é possível observar tal superposição. Trata-se da história de um homem surdo que trabalha como vigia por ordem do general, o qual é de opinião que o homem, por ser surdo, se distrai menos que os demais, estando, por conseguinte, mais apto a exercer a vigilância.

Os estrategistas daquele país vão além, ao julgar que "O ideal era que além de surdo, o vigia não tivesse olfato, paladar e o sentido do tato, para não ser desviado para outros assuntos que não os de vigiar as fronteiras do país" (Ibid., p. 49). As pessoas recriminam em voz baixa o vigia porque consideram que ele tem um grave problema:

O problema dele é que além de vigiar, come. [...]. A preocupação pela vigilância aumentou. Um certo dia, o general decidiu: Nem mais um pedaço de pão para o vigia! Ele tem de se concentrar a ver, não parar de ver! Assim foi. Passaram-se algumas semanas e o país foi invadido, pouco depois de o vigia atento morrer de fome (Ibid., p. 49).

O contexto dessa narrativa é de absoluto nonsense, segundo a lógica formal, pautado que está no fato de que o encontro do trabalhador com a esfera superior de poder o leva à situação extrema do limiar, que é a própria morte, por motivos totalmente injustificados e imorais. A exploração do dominador em relação aos subalternos ressalta a característica marcante das histórias do senhor Brecht, como resultado de quase todos os encontros, em que não se afigura qualquer saída plausível para as situações de crueldade, dominação e terror, as quais se instalam nos embates entre dominadores e dominados.

Assim, as histórias do senhor Brecht seguem uma rotina: a de apresentar personagens e situações próprias do sujeito e do cronotopo do limiar. Neste tempo/espaço, os indivíduos são confrontados com sofrimentos físicos e morais, chegando mesmo à morte. Presas de destinos cruéis, a tais 
pessoas não é dado escolher, cabendo-lhes apenas submeter-se à inexorabilidade dos fatos, aceitando como usual o improvável.

Em "Os turistas", o caos e o absurdo fazem parte da paisagem, como se fossem árvores ou acidentes geográficos. Trata-se de um relato, no qual turistas, por um erro da agência de viagens, descem do avião em meio ao desenrolar de uma guerra.

Como fazia sol, e já que tinham trazido os bronzeadores e trajes de banho, os turistas sentaram-se nas varandas do hotel, a apanhar no corpo aquela luz quentinha, enquanto soavam os barulhos de bombas e tiros. Já que traziam mapas e um roteiro da cidade decidiram dar uns passeios e visitar as ruínas de edifícios, comparando-as com as ultrapassadas indicações do guia turístico. Já que traziam máquinas fotográficas ao pescoço decidiram tirar fotografias dos cadáveres espalhados pela rua (Ibid., p. 48, sublinhado nosso).

Tal como o homem contemporâneo, bombardeado diariamente por cenas de reportagens que mostram uma violência explícita, também as personagens da narrativa se sentem anestesiadas, e até aproveitam, como turistas, o cenário de catástrofe como se fosse algo "exótico".

Em "Sintaxe", é abordado o tema da morte tomado como casualidade ou acidente:

Alguns erros de sintaxe no texto que condenava um homem à morte transformaram esse homem em novo Rei. Esse novo Rei, que escapara por um triz sintático à pena de morte, decidiu utilizar outros meios para determinar o enforcamento do antigo rei. Evitando escrever uma única linha, falou. Porém, explicou-se mal. Os seus próprios homens, obedecendo às suas palavras, enforcaram-no (Ibid., p. 63).

As histórias do senhor Brecht são, portanto, pontuadas por uma rotina fatalista, em que as personagens são vítimas permanentes, não tendo como fugir, o que as coloca como típicos sujeitos permanentes do limiar. 
Segundo a teoria bakhtiniana (1988, p. 354), este é talvez o cronotopo de maior intensidade emotiva, que pode estar associado ao cronotopo do encontro, porém de modo mais abrangente. Em Dostoiévski, por exemplo, observam-se variantes desse cronotopo, como o cronotopo da escada, da antessala, do corredor, da rua, da praça, os quais constituem os lugares da ação nas obras do romancista russo.

Nesse tempo/espaço ocorrem as crises, as ressurreições, as clarividências e os insights, bem como as decisões importantes, que influem sobre o desenrolar de uma vida. Nele, o tempo parece não ter duração específica, estando dissociado do curso normal do tempo biográfico.

Em Os senhores, pode-se observar que Tavares situa tal tempo/espaço como o das situações limite ou extremas, que se configuram em desfechos inusitados de viés trágico ou absurdo, de mudanças repentinas, de acordo com a descrição feita por Bakhtin (Idem, p. 354).

Poder-se-ia dizer que, especialmente em $\mathbf{O}$ senhor Brecht (TAVARES, 2005), o cronotopo do limiar se reflete em mudanças de vida, as quais resultam quase sempre na irreversibilidade irrecorrível, no abismo, na morte, na mutilação, no desastre, na queda real ou simbólica, estendendo-se até aos mortos.

De acordo com Bakhtin (1988, p. 361), "[...] os significados existem não apenas na reflexão abstrata; a reflexão artística também tem relação com eles", o que pressupõe que cabe à interpretação do analista a inserção do elemento de apreciação da obra, seja em seus aspectos particulares como no todo, conferindo à análise impregnações da vivência pessoal e sociocultural do intérprete.

Para o autor russo, a fim de que haja a penetração desses significados "[...] na nossa experiência (experiência social, inclusive), tais significados, quaisquer que eles sejam, devem receber uma expressão espaço-temporal qualquer, ou seja, uma forma sígnica audível e visível por nós (um hieróglifo, uma fórmula matemática, uma expressão verbal e linguística, um desenho, etc.). Sem esta expressão espaço-temporal é impossível até mesmo a reflexão mais abstrata" (Idem, p. 361-362, grifo do autor). 
Do ponto de vista semântico, pode-se notar que, a partir da análise dos cronotopos, é possível observar que há um entrelaçamento de elementos da arte, da ciência e da cultura em geral na obra de Gonçalo M. Tavares. Tais elementos conferem significações especiais, segundo os cronotopos em que se inserem as personagens, variando segundo os temas, os motivos e o substrato têmporo-espacial em que se desenvolvem as ações do enredo, remetendo, posteriormente, a outros significados mais sutis, em que a análise se estende a planos mais abstratos. 


\section{A CADA SENHOR O QUE LHE PERTENCE}

As personagens da série Os Senhores, de Gonçalo M. Tavares, caracterizam-se, em sua maioria, por um aprumo no vestir, pelo uso de chapéu, pelos gestos metódicos, pela formalidade no trato interpessoal, pela linguagem igualmente formal, e por manifestarem comportamentos aparentemente insólitos. $O$ aspecto conservador das suas vestimentas se choca com o inusitado de suas falas e ações, à semelhança de indivíduos deslocados do século XIX para a contemporaneidade, convivendo em planos espaço-temporais simultâneos, regidos por parâmetros não convencionais.

Desse modo, em geral austeras na aparência, com todas as peças do vestuário e os cabelos em ordem, as personagens revelam, organização e formalidade extremas nas ações do dia-a-dia, o que contrasta com a extravagância de suas falas e atitudes.

As personagens se estabelecem cronotopicamente em unidades diegéticas autônomas, vizinhos quase incomunicáveis, habitantes de universos paralelos, porém, não iguais, regidos que são por lógicas próprias, distintas, assimétricas e excêntricas de per $\mathrm{si}$, circunscritas aO Bairro, vivendo fisicamente próximas, mas infinitamente distanciadas por suas idiossincrasias.

Do ponto de vista comportamental, e quando assumem a posição de personagens narradores, os senhores são igualmente formais no uso da língua e minuciosos ao dar explicações. Algumas narrativas, aparentemente despretensiosas, apresentam camadas de sentido complexas, que merecem análise cuidadosa.

Assim, o rigor na forma de vestir das personagens e a aparente clareza e simplicidade das narrativas ajudam a compor um quadro formal e semântico complexo, em que o leitor se vê frente ao descabido apresentado como lógico, a transgressões e opacidades de sentido, a paradoxos, a postulados pseudocientíficos, a definições, que contrariam princípios de causa e efeito, a 
hipóteses e provas insustentáveis, tudo apresentado com rigor cartesiano, ilustrado graficamente, algumas vezes, por meio de desenhos e esquemas.

Para efeito de clareza, dividimos este capítulo em partes, segundo as características de cada senhor, agrupando alguns em pares e deixando outros em separado, procurando demonstrar as relações Eu-Outro, e ressaltando a busca que empreendem por uma identidade que justifique suas maneiras peculiares de ser e de estar no mundo, da mesma forma que procuram preencher seu vazio existencial por tentativas de encontro com a alteridade. 


\section{1 Consciência e busca: o senhor Breton e o senhor Calvino}

"O verso perfeito é irmão daquilo que não conseguimos agarrar" ( $O$ senhor Breton) ${ }^{14}$.

"Mas ao mesmo tempo existe aquela sensação de que estão todos dentro do estômago da baleia, de que aquelas pessoas que ele vê na cidade, cheias de pressa, de um lado para o outro, a discutir percentagens, e ele próprio, há muito foram comidos" ( 0 senhor Calvino) ${ }^{15}$.

Os senhores Breton e Calvino, em que pese o fato de apresentarem comportamentos bastante distintos, têm em comum a busca pelo autoconhecimento e pelo encontro com o Outro. Além disso, ambos têm um nível de consciência que os leva a constatar as dificuldades com que se defrontam, da mesma forma que o homem da contemporaneidade, sendo uma das mais importantes, a que se refere à questão identitária.

$\mathrm{Na}$ tentativa de encontrar respostas para as questões fundamentais da existência, o senhor Breton entrevista a si mesmo usando um espelho. De modo alternado, ele se coloca nas posições de entrevistador e entrevistado, elaborando teorias, executando raciocínios complexos nos campos da literatura, especialmente da poesia, e das questões ontológicas, que sempre afligiram 0 homem de todos os tempos. Metódico, ele inicia os questionamentos: "la começar a entrevista. O senhor Breton sentou-se, pegou um cigarro, fumou um pouco. Ligou o gravador. Começou a entrevista" (TAVARES, 2009, p. 7).

O objetivo do entrevistador é levar a outra parte de si a refletir sobre assuntos fundamentais da vida humana, especialmente no que se refere à oposição que aparentemente se coloca entre os temas da materialidade e outros, como a arte e a literatura, intangíveis de per si. Ao final de longas divagações, ele dirige os seus questionamentos ao entrevistado.

\footnotetext{
${ }^{14}$ TAVARES, 2009, p. 50.

${ }^{15}$ TAVARES, 2007c, p. 13.
} 
Assim, o entrevistador teoriza, inicialmente, acerca do que atormenta o homem de hoje: a falta de perspectiva, representada pelo tédio, que é a segurança monótona do interior da casa; a insegurança e a incerteza sobre o desconhecido, representada pelo medo da noite, a saída da casa. Entre os dois sentimentos fica a poesia, a porta que permite entrar e sair, ousar o enfrentamento do medo, e retornar, depois, para a segurança da casa.

Deixe-me colocar-Ihe uma questão, senhor Breton. Todos conhecemos a noite e os dois lados que todas as noites têm: a noite dentro de casa e a noite fora de casa. Ou seja: há a tranquilidade e o esperado e há, ainda, o medo e a estranheza. Claro que se poderá sempre dizer que a poesia não se encontra nem em um lado nem no outro: a noite tem dois lados e a poesia é a porta da casa no momento em que é aberta e o escuro cobre a relva e o céu. Mas quando alguém tem medo, deve correr para casa; e quando sente tédio, deve correr para a parte de fora da noite. E a poesia, que parece uma coisa parada, resolve, ao mesmo tempo, o tédio e o medo; o que é bom e dois, sendo uma única, a poesia (Idem, p. 11, sublinhado nosso).

O medo e o tédio, mencionados no discurso inicial do senhor Breton, são os elementos a que se refere Giddens, entre outros, para explicar a sensação de perda e de deslocamento sentidos pelo homem da modernidade tardia diante da ausência de referenciais:

Além de sua reflexividade institucional, a vida social moderna é caracterizada por profundos processos de reorganizacãa do tempo e do espaço, associados à expansão de mecanismos de desencaixe - mecanismos que descolam as relações sociais de seus lugares específicos, recombinando-as através de grandes distâncias no tempo e no espaço. A reorganização do tempo e do espaço, somada aos mecanismos de desencaixe, radicaliza e globaliza traços institucionais preestabelecidos da modernidade (GIDDENS, 2002, p. 10, sublinhado nosso). 
Buscando igualmente pontos de referência e respostas às suas questões existenciais, o senhor Breton faz um percurso de autoconhecimento, o qual se dá pela cisão do Eu em duas personae. Pode-se supor que, ao não ter clareza de si, o senhor Breton precisa ver-se refletido no espelho, para ser capaz de ver também a alteridade. Seu outro lado, um constructo da sua imaginação, é a estratégia planejada para obter as respostas.

A entrevista se constitui, portanto, de reflexões e autorreflexões, por meio das quais o entrevistador faz uso de analogias e metáforas complexas e sutis para ilustrar suas perguntas. O seguro senhor Breton, investido da persona do entrevistador, se impõe sobre o tímido e coagido entrevistado, o qual, não responde aos densos questionamentos:

[...] parece-me que o importante no mundo é existir a compreensão de que um chapéu bonito não promove ideias na cabeça. Ou seja: a estética é um assunto que pouco dialoga com o raciocínio. Um homem dançando pode ser bonito, mas um homem pensando nunca é bonito. E se um homem dançar enquanto pensa, esse homem terá pensamentos estúpidos [...]. Não é uma regra, mas poderia ser: dançar é incompatível com a resolução de uma equação de segundo grau (TAVARES, 2009, p. 40, sublinhado nosso).

Diferentemente do introvertido senhor Breton, o senhor Calvino é essencialmente voltado para o mundo exterior, embora seja um indivíduo reflexivo ao seu modo. Mesmo em sonhos, os eventos têm relação com a exterioridade, o entorno fora da casa, as ruas dO Bairro, o mundo circundante.

Como o senhor Breton, ele também está em busca de sentidos e respostas. Sua estratégia de busca é figurativizada em seu caminhar incessante pelas ruas dO Bairro. Andar para o senhor Calvino é abrir-se a possibilidades variadas, entre as quais estão as tentativas que faz para encontrar o Outro. Assim, como mencionado anteriormente, quando este senhor atravessa $O$ Bairro portando uma vara metálica exatamente paralela ao solo, ele está em busca de uma reconfortante sensação de equilíbrio, de maneira a estabelecer um contraponto ao inusitado de seus atos. Nesse 
sentido, a vara figurativiza tal equilíbrio, carregada intencionalmente em posição paralela ao solo:

Não levo apenas uma vara metálica - dizia Calvino -, levo uma vara metálica paralela ao solo. Era por este motivo que segurava com vigor e exatidão no centro da vara e jamais relaxava. Quem o visse sair de manhã de casa poderia reparar na tensão dos músculos do seu braço direito, tensão que visava evitar qualquer tremura, e poderia ainda admirar-se o modo como, sem qualquer falha, transportava a vara metálica, a cada segundo, paralela ao solo (TAVARES, 2007c, p. 29, grifo do autor, sublinhado nosso).

De volta a casa, o processo é inverso: a musculatura se relaxa, a vara é passada para a outra mão, que balança livremente, "[...] como alguém que transporta um saco a que não dá qualquer importância" (Idem, p. 30).

Variando de um extremo a outro, entre o tenso e o relaxado, usando as mãos direita e esquerda, carregando o objeto de modo estável ou em movimento, o senhor Calvino figurativiza os opostos de instabilidade e estabilidade, do que é paralelo e diagonal, da firmeza e do relaxamento, metaforizando a busca do equilíbrio, que remete, igualmente, aos extremos em que vive o homem da modernidade tardia. Para esse sujeito, segundo Giddens, aos poucos se torna clara a noção de que

[...] a ansiedade, a confiança e as rotinas cotidianas estão de tal modo ligadas entre si, que podemos facilmente entender os rituais da vida diária como um mecanismo de enfrentamento. Essa afirmação não significa que tais rituais devam ser interpretados em termos funcionais, como meios de redução da ansiedade (e, portanto, de integração social), mas que eles estão ligados ao modo como a ansiedade é socialmente manejada (GIDDENS, 2002, p. 49, sublinhado nosso).

É possível interpretar os passeios do senhor Calvino portando a vara com base na ideia de carnavalização proposta por Bakhtin (2008, p. 204), em que o objeto na posição paralela ao solo é representativo do formal 
estabelecido, do previsto, do simétrico, que não comporta erros ou desvios, em oposição ao balanço relaxado da vara no retorno da caminhada, que implica na possibilidade do diferente, do alternativo, do informal, indicativo da ruptura representada pelo carnaval.

Aqui está em jogo o princípio filosófico carnavalesco na acepção bakhtiniana, em que se opõem os dois comportamentos antagônicos do senhor Calvino no cronotopo da rua: o caminhar direito, simétrico e formal da ida, com a preocupação em manter o paralelismo da vara em relação ao solo, e que é invertido no caminho de retorno, passando a um caminhar informal e relaxado, como a mostrar o direito e o avesso de uma mesma coisa, como num jogo, cujo objetivo é, segundo o senhor Calvino, "[...] aperfeiçoar todos os sábados de manhã, essa específica habilitação técnica e metafísica" (TAVARES, 2007c, p. 30).

O senhor Calvino exerce, a partir desse procedimento rotineiro, o que para ele, como sujeito ex-cêntrico ${ }^{16}$, consiste em um treino para o equilíbrio.

Já que uma falha mínima podia transformar uma paralela ou uma perpendicular em diagonal, qualquer transportador de varas paralelas ao solo da cidade deveria ser pago a peso de ouro; pois, acima do mais, tal demonstrava que um sujeito sabia colocar, com exatidão, a mão no centro das coisas. (Idem, p. 30, sublinhado nosso).

A vara é igualmente sugestiva do uso que dela faz o equilibrista ao caminhar sobre o fio suspenso entre duas plataformas, remetendo ao homem da contemporaneidade, que se mantém precariamente equilibrado em diversas situações que o mundo da modernidade tardia the oferece, e que deve acautelar-se ao manter a vara na posição correta, sob o risco permanente de que, se não o fizer, poderá cair. O "colocar a mão no centro das coisas" manifesta igualmente o desejo da personagem pelo equilíbrio.

\footnotetext{
${ }^{16}$ O termo ex-cêntrico é usado aqui na acepção que Linda Hutcheon (1988) Ihe confere, em que a noção de centro é desafiada pelas instâncias da contemporaneidade, afetando não apenas o viver humano, mas também todas as formas artísticas. (Nota da autora.)
} 
Ainda de acordo com Giddens, esse "equilibrista" contemporâneo vive ciente de que

A modernidade é uma cultura do risco. [...]. Antes, o conceito de risco se torna fundamental para a maneira como tanto os leigos quanto os especialistas organizam o mundo social. [...]. [...] pensar em termos de risco é vital para aferir até que ponto os resultados reais poderão vir a divergir das previsões do projeto [...] (GIDDENS, 2002, p. 11, sublinhado nosso).

$\mathrm{Na}$ verdade, o senhor Calvino vê além das aparências externas, o que revela o seu deslocamento em relação ao seu entorno e às demais pessoas, que orbitam ao redor de simulacros e conveniências. No processo de carnavalização, segundo a visão de Bakhtin (2008), para os senhores, e especificamente para esse senhor, o avesso pode se tornar o direito e viceversa, sendo também possível a um dado evento, representar-se como avesso e direito simultaneamente.

Para Carlos Alberto Faraco,

[...] na utopia de superar toda e qualquer monologização da existência humana, Bakhtin viu no carnaval - entendido não como uma festa específica, mas como todo um modo de apreender 0 mundo [...] uma poderosa força vivificante $\mathrm{e}$ transformadora da vida cultural, dotada de uma vitalidade indestrutível [...] justamente ao permitir uma vida às avessas (FARACO, 2006, p. 77, sublinhado nosso).

No caso dos senhores, não se trata de viver a festa carnavalesca em determinado período, no qual se permitem escapes à lógica formal, mas antes, de cultivar uma visão de mundo por si mesma carnavalizada e assumida como permanente.

Para Linda Hutcheon, coloca-se o desafio a

[...] toda aquela série de conceitos interrelacionados que acabaram se associando ao que chamamos, por conveniência, de humanismo liberal: autonomia, transcendência, certeza, 
autoridade, unidade, totalização, sistema, universalização, centro, continuidade, teleologia, fechamento, hierarquia, homogeneidade, exclusividade, origem. [...] questionar esses conceitos não significa negá-los - mas apenas indagar de sua relação com a experiência [...] (HUTCHEON, 1988, p. 84, sublinhado nosso).

Em menor grau, comparativamente ao senhor Juarroz, o senhor Calvino também cultiva seus momentos privados de vida interior, durante os quais, não gosta de ser interrompido:

Quando se está a pensar (pensou Calvino) é-se interrompido como se nada estivesse a fazer, falam conosco como para um preguiçoso: Senhor... onde fica a rua Le Grand? Calvino respondeu, de imediato: Primeira à direita, depois segunda à esquerda. Depois sobe a rua até lá acima e é aí. Uma grande caminhada - murmurou, solidário, para o homem perdido. $\mathrm{O}$ homem agradeceu e afastou-se. Calvino nunca soube onde ficava a rua Le Grand (TAVARES, 2007c, p. 58-59, sublinhado nosso).

Tal fato explica o modo de ser do senhor Calvino, que nada tem de mentira ou tentativa de enganar o próximo:

Calvino não tinha linguagem suficiente para ficar um dia sem inventar (alguns chamavam $a$ isso mentir). Encolheu os ombros. Não se tratara de uma vingança, pois Calvino não era senhor para sentimentos desses, tratara-se simplesmente de uma reação a uma grosseria fina, essa mania de o mundo, desorientado, interromper, a cada momento, com pedidos de esclarecimento, quem pensa. É assim mesmo, mas ao contrário. Era esta a forma que Calvino utilizava preferencialmente para esclarecer as pessoas (Idem, p. 59-60, sublinhado nosso).

Pode-se notar que a personagem tem comportamentos mais próprios de uma criança do que de um adulto, o que também ocorre com os senhores 
Walser, Valéry e Juarroz, que apresentam, com frequência, atitudes pueris para demonstrar felicidade ou desgosto. Segundo Curtius (1996, p. 144-145), o topos do ancião-menino, puer senex ou puer senilis, como tema recorrente da literatura, é uma criação presente desde o fim da Antiguidade pagã. Segundo o autor:

Todos os períodos primitivos e elevados de uma cultura louvam o jovem e respeitam o velho. Só mais tarde, todavia, se desenvolve um ideal humano em que o contraste da juventude e da velhice tende a equilibrar-se. [...]. Mostram os exemplos que, desde a virada do século II, adotara-se como topos o puer senilis (CURTIUS, 1996, p. 144-145, grifo do autor).

Sendo Calvino um homem sensível e ingênuo, ele deseja compartilhar com o Outro a visão do inusitado, de uma realidade pelo avesso e quase infantil, o que retoma a ideia da praça pública rabelaisiana e de uma forma de pensar carnavalizada. A orientação incorreta sobre a rua Le Grand encontra uma justificativa parcial por parte da personagem, em monólogo interior:

No entanto, não tivera tempo para esclarecer o simpático senhor. É assim como the digo, mas ao contrário. Não se sentia culpado; [...]. Como alguém que tem prazer em mostrar um filme ou um livro de que gostou, também Calvino sabia que se as pessoas fossem diretamente, sem qualquer desvio, para o seu destino, nunca teriam oportunidade de ver e conhecer cantinhos que só os homens muito perdidos descobrem (TAVARES, 2007c, p. 60, sublinhado nosso).

Para Calvino, a rua representa a possibilidade de surpreender-se, o eventual encontro com o inesperado. Pode-se inferir, a partir de tal característica pessoal, uma crítica velada ao homem da contemporaneidade, que não tem tempo a "perder", negando-se o sabor inusitado da surpresa.

O senhor Breton por sua vez não gosta de surpresas. Seu roteiro de perguntas, formuladas cuidadosamente, de modo a exigir do entrevistado reflexão e respostas, repete a rotina de divagações e formulações teóricas iniciais. 
De sua posição, o entrevistado anseia que cesse a opressão inquisitorial, fazendo tentativas para escapar, ainda que temporariamente, do ambiente que o sufoca, umas vezes por cansaço, outras por não ter o que responder.

Mais do que perguntas, o entrevistador faz afirmações complexas, representadas por imagens, símbolos e metáforas de difícil interpretação, dirigidas a um entrevistado que não se sente disposto a refletir.

Mesmo assim, o entrevistador prossegue em seus questionamentos:

Sabemos bem, senhor Breton, que o trabalho não se divide por todos como as fatias de um pão. Há os acomodados e há aqueles que labutam. [...]. O trabalho - aquilo que está ainda por fazer - é o futuro, e o futuro só é definido pelos códigos verbais dos profetas. Aquilo que já está feito - uma mesa ou o pão em cima da mesa - constitui o presente. E assim, também, existem duas poesias: uma com tendência para a paisagem; $\mathrm{e}$ outra, que se distribui sobre o movimento futuro das coisas, o que leva a que a aprendizagem de um verso esteja, algumas vezes, dessincronizada com a aprendizagem do sofrimento pois só se sofre hoje, nunca amanhã (TAVARES, 2009, p. 13, sublinhado nosso).

No entrecho, o senhor Breton alude às incertezas da contemporaneidade, especialmente àquelas pertinentes ao futuro - o devir incerto. Tais perdas de referencial em relação ao espaço/tempo da contemporaneidade constituem, segundo Giddens, um dos mecanismos de "desencaixe" a afetar a vida de pessoas, comunidades e países. De acordo com o autor,

Em vários aspectos fundamentais, as instituições modernas apresentam certas descontinuidades com as culturas e modos de vida pré-modernos. Uma das características mais óbvias que separa a era moderna de qualquer período anterior é seu extremo dinamismo. O mundo moderno é um "mundo em disparada": não só o ritmo da mudança social é muito mais rápido que em qualquer sistema anterior; também a amplitude 
e a profundidade com que ela afeta práticas sociais e modos de comportamento preexistentes são maiores (GIDDENS, 2002, p. 22, grifo do autor, sublinhado nosso).

Observa-se aqui também, da parte do senhor Breton, a carência e a necessidade do Outro, que Ihe seja o contraponto do diálogo. Ao ocupar seus olhos e pensamentos com os vizinhos, o senhor Breton, da posição de entrevistado, supre, em parte, sua necessidade de contato com a alteridade:

Da janela viu passar o senhor Juarroz, de quem se recordara havia pouco. $\underline{O}$ senhor Breton conhecia praticamente todos os seus vizinhos. Sabia pormenores, coisas íntimas até. [...]. [...] 0 senhor Juarroz gostava de comer antes de dormir, [...], $\underline{0}$ senhor Juarroz gostava de ver antes de dormir, para sonhar melhor. [...]. o senhor Juarroz nunca ligava a televisão, optando pela janela. Ali, parado, concentrava-se e via [...]. [...] como ele [...] estava fazendo: ver pela janela (TAVARES, 2009, p. 41, sublinhado nosso).

De todos os senhores, Calvino é o que tem maior consciência de suas próprias limitações, bem como das circunstâncias restritivas que a sociedade contemporânea lhe impõe, percepções essas que lhe ocorrem em sonhos ou por meio de insights.

Na narrativa "Três sonhos: $1^{\circ}$ sonho de Calvino", emerge uma crítica ao mundo da contemporaneidade, no qual a velocidade dos acontecimentos põe o indivíduo em contínuo processo de aceleração. No sonho, o senhor Calvino tem suas roupas e sapatos atirados do alto de um edifício de mais de trinta andares. Durante a queda, ele agarra os objetos que caem, vestindo-se antes de chegar ao chão:

Calvino não tem tempo para pensar, está atrasado, atira-se também da janela, como que em perseguição. Ainda no ar alcança os sapatos. Primeiro, o direito: calça-o; depois, o esquerdo. No ar, enquanto cai, tenta encontrar a melhor posição para apertar os atacadores. Com o sapato esquerdo falha uma vez, mas volta a repetir, e consegue. Olha para 
baixo, já se vê o chão. Antes, porém, a gravata; Calvino está de cabeça para baixo e com um puxão brusco a sua mão direita apanha-a no ar e, depois, com os seus dedos apressados, mas certeiros, dá as voltas necessárias para o nó: a gravata está posta. Os sapatos, olha de novo para eles: os atacadores bem apertados; dá o último jeito no nó da gravata, bem a tempo, é o momento: chega ao chão, impecável (TAVARES, 2007c, p. 9).

Observa-se aí uma narrativa onírica frenética, que, na realidade contemporânea, se reproduz de modo aproximado, exceto pela queda do alto edifício, que parodia o ritmo apressado em que vive o homem da atualidade. A rapidez com que se desenrolam os eventos cotidianos é representada pela aceleração têmporo-espacial de objetos que caem do alto de um prédio. É como se ocorresse uma real perseguição de um indivíduo atrasado, indo atrás de coisas a agarrar e de tarefas a dar conta, em uma sequência vertiginosa que emula a rapidez de uma queda.

Anthony Giddens, ao falar da aceleração da vida do homem da contemporaneidade como sendo a de um "mundo em disparada", afirma que tal dinâmica pode ser explicada por três fatores: o primeiro é a separação de tempo e espaço:

Não há sociedade em que os indivíduos não tenham sentido de futuro, presente e passado. Cada cultura tem alguma espécie de marcador espacial padronizado que designa uma consciência especial de lugar. Em situações pré-modernas, porém, tempo e espaço se conectavam através da situacionalidade do lugar (GIDDENS, 2002, p. 22, grifo do autor, sublinhado nosso).

Calendários e mapas eram, de acordo com a formulação de Giddens, os recursos que ordenavam as relações têmporo-espaciais, funcionando como “[...] pré-requisitos para o 'distanciamento' no tempo e no espaço pressupostos pelo surgimento de formas mais extensas do sistema social" (Idem, p. 22, grifo do autor). 
Para ele, a invenção do relógio mecânico constituiu-se na primeira marca do processo de separação de tempo e espaço, criando o que o autor denomina de uma dimensão "vazia" de tempo. Segundo Giddens,

O uso generalizado de instrumentos de marcação do tempo facilitou, mas também pressupunha, mudanças profundamente estruturadas no tecido da vida cotidiana [...]. Um mundo com um sistema de tempo universal e zonas de tempo globalmente padronizadas, como o nosso hoje, é social e experiencialmente diferente de todas as eras pré-modernas (Ibid., p. 23, grifo do autor, sublinhado nosso).

Para o autor, os conceitos de organização e organizações, são impensáveis se não se supuser a reintegração do tempo e do espaço, isto é, "A organização social moderna supõe a coordenação precisa das ações de seres humanos fisicamente distantes; o 'quando' dessas ações está diretamente conectado ao 'onde', mas não, como em épocas pré-modernas, pela mediação do lugar" (Ibid., p. 23, grifo do autor).

Esse primeiro fator de descontinuidade dá ensejo à segunda influência a marcar o dinamismo da contemporaneidade: trata-se do fenômeno do desencaix ${ }^{17}$ das instituições sociais. Para o autor (Ibid., p. 24, grifo do autor), desencaixe é, pois, sinônimo de descolamento.

Visto sob o prisma do assim chamado desencaixe, conforme expresso pelo autor, o dinheiro é o primeiro dos fatores que põe de parte a ideia de tempo-espaço, já que permite, por seu valor padronizado, transações entre indivíduos que nunca se encontraram pessoalmente. O outro fator é o que ele denomina de sistemas especializados, os quais, igualmente,

[...] põem entre parênteses o tempo e o espaço dispondo de modos de conhecimento técnico que têm validade independente dos praticantes e clientes que fazem uso deles.

\footnotetext{
17 Anthony Giddens (2002) ressalva o uso do termo desencaixe em oposição ao conceito de diferenciação, que é usado algumas vezes por sociólogos como modo de estabelecer um contraste entre sistemas sociais pré-modernos e modernos. O termo diferenciação deixaria de captar o que o autor considera essencial para a compreensão da ideia de "descolamento" das relações sociais dos contextos locais bem como sua posterior rearticulação através de partes indeterminadas do tempo e do espaço. (Nota da autora.)
} 
[‥]. Os sistemas especializados não se limitam às áreas tecnológicas; estendem-se às próprias relações sociais e às intimidades do eu (Ibid., p. 24, sublinhado nosso).

Tais relações dependem do que se poderia denominar de um contrato de confiança entre as partes, segundo a acepção de Anthony Giddens, que "[...] pressupõe um salto para o compromisso, uma qualidade de 'fé' que é irredutível". Sob este aspecto, "[...] a confiança põe entre parênteses o conhecimento técnico limitado que a maioria das pessoas possui sobre a informação codificada que afeta rotineiramente suas vidas" (Ibid., p. 24-25, grifo do autor).

Por fim, o terceiro mecanismo de desencaixe identificado pelo autor, com grande influência sobre a vida social da contemporaneidade, é a reflexividade. De acordo com ele,

[...] a reflexividade da modernidade de fato solapa a certeza do conhecimento, mesmo nos domínios centrais da ciência natural. A ciência depende não da acumulação indutiva de demonstrações, mas do princípio metodológico da dúvida. Por mais estimada e aparentemente estabelecida que uma determinada doutrina científica seja, ela está aberta à revisão ou poderá vir a ser inteiramente descartada - à luz de novas idéias ou descobertas. A relação integral entre a modernidade e a dúvida radical é uma questão [...] existencialmente perturbadora para os indivíduos comuns (Ibid., p. 26, grifo do autor, sublinhado nosso).

No caso do senhor Calvino, tal sensação emerge em " $3^{\circ}$ sonho de Calvino", no qual a personagem está tão envolvida com o seu sócio em uma discussão sobre porcentagens que não percebe que ambos são, de repente, engolidos por uma baleia, fato que não interrompe o diálogo:

A discussão está acesa e Calvino empenha-se nela cada vez mais; vira depois as costas ao seu sócio e sai para a rua: observa as pessoas a andarem de um lado para o outro. $\underline{\text { Os }}$ poucos que não estão com pressa, aqueles que param, 
discutem entre si, percentagens também: 30 , não, 37!, não, não, 32! Todos discutem, ele próprio não consegue deixar de repetir, para si próprio: $43 \%$, pelo menos $43 \%$ ! Mas ao mesmo tempo existe aquela sensação de que estão todos dentro do estômago da baleia, de que aquelas pessoas que ele vê na cidade, cheias de pressa, de um lado para o outro, a discutir percentagens, e ele próprio, há muito foram comidos (TAVARES, 2007c, p. 13, sublinhado nosso).

É de ressaltar, no entrecho, alguns dos mecanismos de desencaixe de que fala Giddens. O primeiro deles é a desconexão de tempo e espaço, em que o lugar, seja ele a rua ou o ventre da baleia, não constitui um referencial de mediação para que o fato, isto é, a discussão, ocorra. A mudança espacial da rua para o ventre do animal não é sequer percebido pelos interlocutores, que prosseguem o diálogo.

Ao sair para a "rua", no interior da baleia, Calvino se dá conta de que muitos estão apressados, e, até mesmo os que não estão, discutem porcentagens, ou seja, números, que representam, em última instância, valores monetários, referencial comum e importante para os indivíduos da contemporaneidade, onde quer que estejam.

A variação dos números das porcentagens, $30,37,32,43$, sugere 0 quociente de incerteza quanto à valoração do que é essencialmente material de per si. Está implícita nesta variação, a questão levantada por Giddens, em que a reflexividade supõe uma contínua revisão e reavaliação de dados, já que as dúvidas prevalecem sobre as certezas e as mudanças são frequentes.

Por fim, o insight de Calvino quanto ao fato de que todos, os apressados e os sem pressa, foram todos, indistintamente, engolidos pela baleia, revela a metaforização da rearticulação têmporo-espacial de que fala Giddens, e que engloba todos em um mesmo "lugar", não importando onde estejam.

A descrição do sonho de Calvino estabelece também dois intertextos: o primeiro e mais óbvio se refere ao episódio do Livro de Jonas ${ }^{18}$, no Velho Testamento, em que a personagem, desobedecendo às ordens do Senhor, é

${ }^{18}$ Jonas, Velho Testamento. (Ver Referências.) 
jogada para fora do navio por seus companheiros, para que se acalme a fúria de Deus, que "[...] lançou sobre o mar um forte vento, e fez-se no mar uma grande tempestade, e o navio estava a ponto de se despedaçar" (Jn 1.4, p. 791).

Feitos sacrifícios e votos ao Senhor, e tendo sido Jonas lançado ao mar, "Deparou o Senhor um grande peixe para que tragasse a Jonas; e esteve Jonas três dias e três noites no ventre do peixe" (Idem, 1.17, p. 792).

A ideia de punição no Livro de Jonas é modificada na narrativa de Tavares, mas, ainda assim, constitui uma penalidade o fato de terem sido todos, o senhor Calvino e os demais, engolidos por uma baleia, sem 0 perceberem, imersos que estão em uma vida acelerada e materialista, que prossegue sem alteração no ventre do animal. Somente ao senhor Calvino acode a consciência momentânea, ainda em sonho, de que todos, de uma maneira ou de outra, há muito haviam sido comidos.

O segundo intertexto diz respeito ao cronotopo rabelaisiano, conforme descrito por Bakhtin (2008, p. 253). Em Pantagruel ${ }^{19}$, livro escrito por François Rabelais em 1532, o gigante faminto e sedento Pantagruel se envolve em aventuras, cujas imagens hiperbólicas estão ligadas às funções corporais, representação da alegre e material manifestação da vida contra o terror cósmico:

Uma certa lembrança obscura das perturbações cósmicas passadas, um certo temor indefinível dos abalos cósmicos futuros dissimulam-se no próprio fundamento do pensamento e da imagem humanos. [...]. [...] (é o temor inspirado pelas coisas materiais de grande porte e pela força material invencível), é utilizado por todos os sistemas religiosos com o fim de oprimir o homem, de dominar a sua consciência. [...]. Assim, nas criações populares que exprimiam esse combate, forjava-se uma autoconsciência verdadeiramente humana, liberada de todo medo (Idem, p. 294-295, grifo do autor, sublinhado nosso).

\footnotetext{
${ }^{19}$ In: Obras, Pléiade, p. 303; livro de bolso, v.l, p. 407, apud BAKHTIN, M. A cultura popular
} na Idade Média e no Renascimento: o contexto de François Rabelais, 2008, p. 295. 
Em um desses episódios, é descrita uma viagem do narrador Alcofrybas dentro da boca de Pantagruel:

Tendo chegado à bocarra aberta do seu herói, mestre Alcofrybas aí descobre todo um universo desconhecido: vastos prados, florestas, cidades fortificadas. Essa boca abriga mais de vinte e cinco reinos. Os seus habitantes estão convencidos de que o seu mundo é mais antigo que a terra (Ibid., p. 295, grifo do autor, sublinhado nosso).

A obra de Rabelais enfatiza, segundo Bakhtin,

O elemento de relatividade e de evolução [...], em oposição a todas as pretensões de imutabilidade e atemporabilidade do regime hierárquico medieval. Todas essas imagens topográficas visavam a fixar o próprio momento da transição e da alternância, a de duas autoridades e duas verdades, a antiga e a nova [...] (Ibid. p. 70, sublinhado nosso).

Analogamente, a atual transição entre as épocas pré-modernas e a modernidade, segundo Giddens (2002, p. 33), é marcada por dualidades, ou mesmo multiplicidades, referentes aos dois períodos em convívio simultâneo, como um embate que "[...] carrega resíduos de concepções do destino derivadas de eras pré-modernas".

Certo dia, o senhor Calvino reflete sobre o fato de que havia se esquecido do que iria acontecer no dia seguinte, revelando em monólogo interior seu gosto pela surpresa: "[...] tal esquecimento, a que vulgarmente se chama incapacidade para prever o futuro - era uma espécie de referência existencial" (TAVARES, 2007c, p. 58).

Nas ocasiões em que o senhor Calvino leva cuidadosamente o balão preso ao pulso, este representa um elemento substitutivo do Outro, servindo também a um propósito adicional: "Dar uma atenção invulgar (mesmo que apenas durante alguns dias) a um objeto como este era, para Calvino, um exercício fundamental que the permitia treinar o olhar sobre as coisas do 
mundo. No fundo, o balão era um sistema simples de apontar para o Nada" (Idem, p. 16, sublinhado nosso).

A necessidade do Outro, manifesta em todos os senhores, é o que leva o senhor Calvino a cuidar do balão como se vivo fosse, tal qual um ser frágil que a qualquer momento pode perecer. Isto é o que lembra a Calvino "[...] a pequena distância que existe entre a enorme e forte vida que ele agora possuía e a enorme e forte morte que andava sempre [...], a cada momento a circular em seu redor" (Ibid., p. 17, sublinhado nosso).

Pode-se falar aí da consciência de Calvino em relação à perecibilidade das coisas e das pessoas, relacionando a fronteira tênue que separa vida e morte ao fio que o liga ao balão, elemento que, a qualquer instante, pode se romper, tal qual o fio de prata mencionado no Livro do Eclesiastes ${ }^{20}$ bíblico, em que o narrador, chegando, ao final, fala da velhice e da proximidade da morte:

Lembra-te do teu Criador nos dias da tua mocidade, antes que venham os maus dias, e cheguem os anos dos quais dirás: Não tenho neles prazer; [...]; como também quando temeres o que é alto, e te espantares no caminho, e te embranqueceres, como floresce a amendoeira, e o gafanhoto te for um peso, e te perecer o apetite; porque vais à casa eterna, e os pranteadores andem rodeando pela praça; antes que se rompa o fio de prata, e se despedace o copo de ouro, e se quebre o cântaro junto à fonte, e se desfaça a roda junto ao poço, e o pó volte à terra, como o era, e o espírito volte a Deus, que o deu (Ec 12.1-7, p. 600 , sublinhado nosso).

A atenção que Calvino dá às pequenas coisas é característica da sua percepção da realidade em um nível mais profundo, o qual ultrapassa o corriqueiro do mundo circundante. Tal ideia se torna clara em "Massa de letras (sopa)", no qual, ao tomar uma sopa de letrinhas, e ainda que usasse cuidadosamente o guardanapo, resta pendente, no lado direito do seu queixo, um teimoso $A$. Ele se encanta com a resistência daquele $A$, aproximando-o, por analogia, a um ser vivo:

${ }^{20}$ Eclesiastes, Velho Testamento. (Ver Referências.) 
Calvino, olhando-se agora ao espelho, não pôde deixar de admirar a capacidade de resistência daquela letra aos anteriores enérgicos movimentos do seu guardanapo, e observava então aquele A como quem observa um alpinista agarrando-se desesperadamente para não cair. (TAVARES, 2007c, p. 21, sublinhado nosso).

Calvino representa 0 contraponto à impaciência do homem contemporâneo, que vive em uma espécie de "aceleração temporal". Para o indivíduo da "modernidade tardia", mencionada por Giddens (2002, p. 22), habitante de um "mundo em disparada", só às atividades "importantes" é conferido destaque. Para esse homem, perder tempo a "[...] treinar o olhar sobre as coisas do mundo" ou "[...] apontar para o Nada" torna-se um desperdício perigoso para o seu projeto de vida.

Em um jogo metonímico entre continente e conteúdo, representado pelo ar e pelo balão, o senhor Calvino chama a atenção para o que é aparentemente insignificante, e que não tem lugar na vida do homem da contemporaneidade. No que respeita à carência afetiva, traço comum a todos os senhores, há tentativas por parte deste senhor de aproximação em relação ao Outro, acompanhadas de rituais simbólicos, os quais sinalizam apelos à proximidade.

Na narrativa "A janela", por exemplo, o senhor Calvino, minucioso e obsessivo, costuma fechar as cortinas, abotoando-as. "Quando de manhã abria a janela, desabotoando, com lentidão, os botões, sentia nos gestos a intensidade erótica de quem despe, com delicadeza, mas também com ansiedade, a camisa da amada" (TAVARES, 2007c, p. 19).

A "janela de abotoar" do senhor Calvino marca igualmente a diferença essencial entre os mundos interno e externo, como uma fronteira que delimita 0 espaço do Outro e o de si mesmo.

Para ele, assim como para os senhores Breton e Juarroz, a janela representa a abertura para o mundo, para o Outro do qual desejam se aproximar. Segundo uma abordagem metonímica e metafórica, a janela é não somente um meio para chegar ao Outro, como também simboliza e equivale a 
este Outro. Desempenhando o papel das vestes, as cortinas devem ser vagarosamente abertas por Calvino, como em um ritual erótico. A visão do objeto do desejo, a mulher amada em potencial, só poderia ser contemplada a partir da janela.

Tal objeto se localiza simultaneamente, portanto, na janela e para além dela, isto é, no tempo/espaço da casa do senhor Calvino, como a janela em si, e também lá fora, na rua, o tempo/espaço idealizado de um possível encontro: "Calvino, para espreitar por essa janela, tinha primeiro de desabotoar os sete botões, um a um. Depois sim, afastava com as mãos as cortinas e podia olhar, observar o mundo. No fim, depois de ver, puxava as cortinas para a frente da janela e fechava cada um dos botões. Era uma janela de abotoar" (Idem, p. 19).

A intensidade do desejo e a importância conferida ao relacionamento ainda não realizado colocam o senhor Calvino em um cronotopo idílico, a partir do original descrito por Bakhtin (1988, p. 333), ao qual se superpõe o cronotopo do encontro em potencial, "Como se o mundo não fosse uma coisa disponível a qualquer momento, mas sim algo que exigia dele, e dos seus dedos, um conjunto de gestos minuciosos" (TAVARES, 2007c, p. 19).

A valorização e o desejo do encontro com o Outro, por parte de todos os senhores, constitui-se na própria exposição de suas necessidades em um sentido emocional mais profundo. Daí a lentidão de movimentos do senhor Calvino ao "despir a janela", o cuidado excessivo, o curto tempo de contemplação, os gestos medidos. Para ele, "Daquela janela o mundo não era igual" (Idem, p. 19).

Seu desejo de aproximação e de contato fica claro quando da descrição do seu modo de ser em situações de relacionamento social:

Calvino era portador de uma insólita gentileza. Em encontros sociais, [...] apressava-se no ato de se sentar primeiro em várias cadeiras, passando sucessivamente de umas para outras, ainda todos os convivas permaneciam de pé parecendo pois mal-educado; [...] o que Calvino fazia era experimentá-las [...] para depois poder oferecer ao presente mais ilustre [...] a mais confortável e digna. Não era 
experimentador de vinhos, era experimentador de cadeiras (Ibid., p. 66, sublinhado nosso).

O narrador onisciente, ao comparar um provador de vinhos ao senhor Calvino, "o provador de cadeiras", faz emergir as instâncias do cômico e do absurdo presentes em Rabelais e em Tavares, com diferentes especificidades e características. Ambos têm em comum a capacidade do riso e para o riso, de forma mais aberta e grotesca em Rabelais, e mais velada e oblíqua em Tavares.

Segundo Bakhtin, por nunca terem tido caráter oficial, os gêneros cômicos sempre foram os mais livres e os menos sujeitos a regulamentação:

A Europa não conheceu nem a mística, nem a magia do riso; o riso jamais foi contaminado nem mesmo pelo simples burocratismo, pelo espírito oficial necrosado. Por isso o riso não podia se degenerar e mentir, como mentia o sério, sobretudo o patético. 0 riso permaneceu fora da mentira oficial que se revestira de seriedade patética. Assim, todos os [...] padrões de linguagem foram impregnados pela mentira, por convenções perniciosas, pela hipocrisia e pela falsidade. Somente o riso não foi contaminado (BAKHTIN, 1988, p. 342343 , sublinhado nosso).

Há, tanto Rabelais quanto em Tavares, de maneiras distintas, a busca por revelar e destruir valores e hierarquias, expondo de forma aguda problemas existenciais e sociais, buscando ambos reconstruir novas imagens do homem na literatura, a partir de distorções diegéticas, cronotópicas, linguísticas e de estilo.

Pode-se também estabelecer aí uma correlação diferencial entre a obra rabelaisiana e a obra de Tavares, em que se mesclam a vida privada e a vida pública dos senhores, como em estado de permanente carnavalização, comportando-se eles de forma aparentemente ilógica nos espaços público e privado. É como se o carnaval da praça pública de Rabelais estivesse, de certa 
forma, internalizado no comportamento dos senhores, o que implica nas diferentes apreciações que eles têm do mundo, das pessoas e de si mesmos.

A crítica, que em Rabelais é dirigida ao mundo oficial secular e religioso da Idade Média, em Tavares tem como propósito expor e criticar o homem da contemporaneidade, quer nos aspectos públicos quer nos privados, denunciando mazelas sociais, rupturas e desvios em diferentes níveis da sociedade, os quais afetam indivíduos e comunidades. Tal função da literatura é comentada por Zygmunt Bauman:

[...] a vocação da ficcão artística (é) servir de irônica e irreverente contracultura à cultura tecnológico-científica da modernidade $^{21}$, essa cultura de paixão ordenada, divisões nítidas e disciplina retesada. No mundo que jurou buscar e alcançar a certeza e vai ao outro extremo para transformar a palavra em carne, a ficção artisticamente concebida de mundos alternativos impede que os projetos sejam encerrados em gaiolas e as estruturas planejadas sejam ossificadas em esqueletos mortos. Num mundo dominado pelo medo mortal de tudo o que é contingente, opaco e inexplicável, a ficção artística é uma contínua sessão de treinamento para viver com o ambivalente e o misterioso. Ela ensaia a tolerância e equanimidade para com o inconstante, o contingente, o não inteiramente determinado, o não inteiramente compreendido $\mathrm{e}$ o não inteiramente previsível. Incentiva a reconciliação com a contingência da vida e a polifonia de verdades (BAUMAN, 1998, p. 150, sublinhado nosso).

De sua parte, o senhor Breton, como todos os senhores, está envolvido, de modos diferentes, em tentativas de reorganização da sua realidade instável, em busca da afirmação de uma verdade própria. Com este intuito, de forma consciente ou não, todas as personagens se valem de diversas estratégias

\footnotetext{
${ }^{21}$ Zygmunt Bauman denomina o período em que vivemos como pós-modernidade. Já Anthony Giddens dá o nome de modernidade ao mesmo período, denominando de modernidade tardia o último período do que ele chama de modernidade. O que para Bauman corresponde à modernidade, para Giddens configura-se como eras pré-modernas. (Nota da autora.)
} 
compensatórias, na busca de integrar e reconstituir suas personalidades fragmentadas.

Uma das estratégias é o esforço de aproximação em relação ao Outro, o diferente complementar e ao mesmo tempo semelhante, atitude que é acompanhada por expedientes menores do dia-a-dia, que fornecem algum alívio no sentido de atenuar a solidão. É o que faz o senhor Breton na posição de entrevistado, ao sair para tentar encontrar alguém com quem conversar:

[...] o senhor Breton estava sentindo necessidade de falar com alguém. Aproximou-se do local onde o senhor Eliot costumava dar conferências. E ali estava ele, em pleno discurso. Mais uma conferência, pensou o senhor Breton, e afastou-se. Mas eis que vinha alguém com quem falar. O senhor Kraus (TAVARES, 2009, p. 31).

Findos o passeio e o encontro com o vizinho, a entrevista é retomada na sexta pergunta, em que o entrevistador usa a casa do senhor Walser como recurso de analogia para referir-se à poesia:

[...] poderemos dizer, em paralelo, que um verso introduz, entre duas frases velhas, uma ligeira fissura, e essa fissura pode ser uma outra frase, colocada no meio, com uma velocidade bem diferente da velocidade das velhas (e lentas) frases. [...]. Daí que minha pergunta, [...], esteja relacionada com a aplicação do betume numa parede para remendar fissuras ou orifícios (Idem, p. 35-36, sublinhado nosso).

O entrevistador refere-se aí aos consertos que têm curso na casa do vizinho, o senhor Walser, sendo um deles, o processo de tapar fissuras surgidas assim que termina a construção:

Por seu turno, os homens que se encontravam à volta das paredes - a encher fissuras e orifícios com betume de celulose - disseram também ser impossível terminar ainda durante o dia. Um deles explicava a Walser a dificuldade e a demora dos trabalhos (TAVARES, 2008, p. 36). 
Faz aí o senhor Breton uma crítica à análise literária, processo por meio do qual ocorre uma espécie de desmontagem da obra para fins de estudo. De forma semelhante ao analista, os profissionais que trabalham na morada do senhor Walser, com o objetivo de consertar partes defeituosas, também desconstroem a casa recém-terminada daquele senhor.

Assim, ao analisar uma obra literária, o estudioso corre o risco de tornála um mero objeto de explicação, e as afirmações usadas para tal fim constituiriam, nas palavras do senhor Breton, "[...] uma linguagem direita, homogênea e parva" (TAVARES, 2009, p. 36), como se dá usualmente com o uso de terminologia técnico-acadêmica, distinguindo o senhor Breton tal linguagem da natureza sutil dos versos que escapam pelas fissuras, desde que não estejam completamente fechadas.

Por fim, o senhor Breton termina seu arrazoado analógico com uma síntese dirigida ao entrevistado, que prepara a pergunta a seguir: "Poderemos dizer, em síntese, senhor Breton, que a poesia é a fissura e a análise da poesia é aplicar uma substância densa na fissura até que ela desapareça, e que se torne algo que incomoda por tão plana. Será assim, senhor Breton[?]" (Idem, p. 36).

Ao falar das fissuras como pequenas aberturas por onde "escapam" os versos, o senhor Breton tenta convencer a sua outra parte acerca da importância da literatura, especificamente da poesia, retomando a ideia da "velocidade ideal" mencionada na primeira pergunta, ao falar da janela (p. 12).

$\mathrm{Na}$ oitava pergunta, o entrevistador volta ao tema da literatura, usando a luz de lâmpadas e outras fontes como metáfora do conhecimento:

A questão é a seguinte, senhor Breton: acredita que existe apenas uma lâmpada no mundo ou tem o pressentimento de que há diversas fontes de luz, onde poderemos incluir o sol, Goethe e muitos outros autores? Ou seja, [...]: acredita que a literatura e, em particular, certos livros poderão funcionar como lâmpadas, quando colocados sobre a mesa de um quarto escuro, sem sol ou eletricidade? Poderá um livro conduzir um cego por uma cidade cheia de trânsito [?] (Ibid., p. 45, sublinhado nosso). 
Exprime aí a personagem a importância que confere à literatura e ao conhecimento em geral, o que também é a expressão da voz autoral de Gonçalo M. Tavares, divulgada nas várias entrevistas que concedeu.

Ao fazer uso de perguntas como método indutor de reflexão para a obtenção de respostas, o senhor Breton utiliza um recurso dialético, que se formou sobre um protogênero: o diálogo socrático. A entrevista tem, pois, caráter sociopsicológico, segundo o qual, o objetivo da personagem entrevistador é convencer a outra parte de si a aceitar a sua argumentação e a sua "verdade", base ideológica do protótipo em questão.

Parte da metodologia empregada pelo senhor Breton consiste ainda em utilizar fatos e situações da realidade deslocados dos seus contextos habituais, de maneira a construir analogias e metáforas, como um meio de tornar concretos os seus pontos de vista:

Há quem diga que as palavras são coisas mastigáveis como os alimentos, e há ainda quem entre em pormenores como quem entra numa sala, dizendo que se todas as palavras são mastigáveis e transportáveis pela língua de um lado para o outro da boca, nem todas alimentam os homens; só certos versos o farão (Ibid., p. 27, sublinhado nosso).

Em termos de "descentramento", pode-se afirmar que o senhor Breton é menos excêntrico do que os demais, algo possível de ser observado pelo teor das perguntas formuladas ao entrevistado, bem como pela preocupação quase didática em situar coisas intangíveis e imateriais, como a poesia. É o caso da nona pergunta, em que o entrevistador indaga acerca de medidas e distâncias em relação aos versos, reforçando a intangibilidade e a sutileza destes últimos:

Há ainda uma questão que se relaciona com o comprimento de um verso, senhor Breton. [...]. Terá um verso uma distância orgânica perfeita, uma distância interna que o poeta deverá repetir, de forma consciente ou inconsciente, cada vez que escreve? Não se alude aqui a comprimentos assinaláveis com fita métrica, é claro. Um verso tem vida: portanto, altura por fora; e tem ainda mais vida: portanto, altura, por dentro. E se 
um organismo tem dois mundos, aquele que não se vê é sempre o mais importante, pelo menos este é um pressentimento que eu tenho, senhor Breton. Identifica-se com ele[?] (Ibid., p. 49, sublinhado nosso).

Ao final de todas as teorias e questionamentos, "O senhor Breton desligou o gravador. Levantou-se. Terminara a entrevista. Aproximou-se da janela. Olhou lá para fora. Um vizinho passava" (Ibid., p. 54).

É de notar que em meio às reflexões e aos questionamentos provocados pela entrevista, os momentos de distração do senhor Breton estão sempre ligados a visões reais ou a lembranças do Outro, quer sejam passantes avistados da janela ou fragmentos de memória, evidenciando a carência afetiva que sente em relação à alteridade. 


\section{2 O idílio desfeito e o senhor Walser}

"A casa não era para Walser apenas um lugar que a humanidade conquistara ali à floresta, ao espaço que as coisas não humanas pareciam ter determinado como seu - era ainda uma paisagem ideal para começar a falar com outros homens [...]" (O senhor Walser $)^{22}$.

O cronotopo idílico, caracterizado, segundo Bakhtin (1988, p. 333), pelas temáticas do amor, da família e do trabalho, aparece transformado na obra de Tavares quanto à personagem do senhor Walser. Ele é o único que mora em uma floresta, afastada geograficamente dos edifícios dO Bairro, como assinalado na ilustração abaixo ${ }^{23}$.

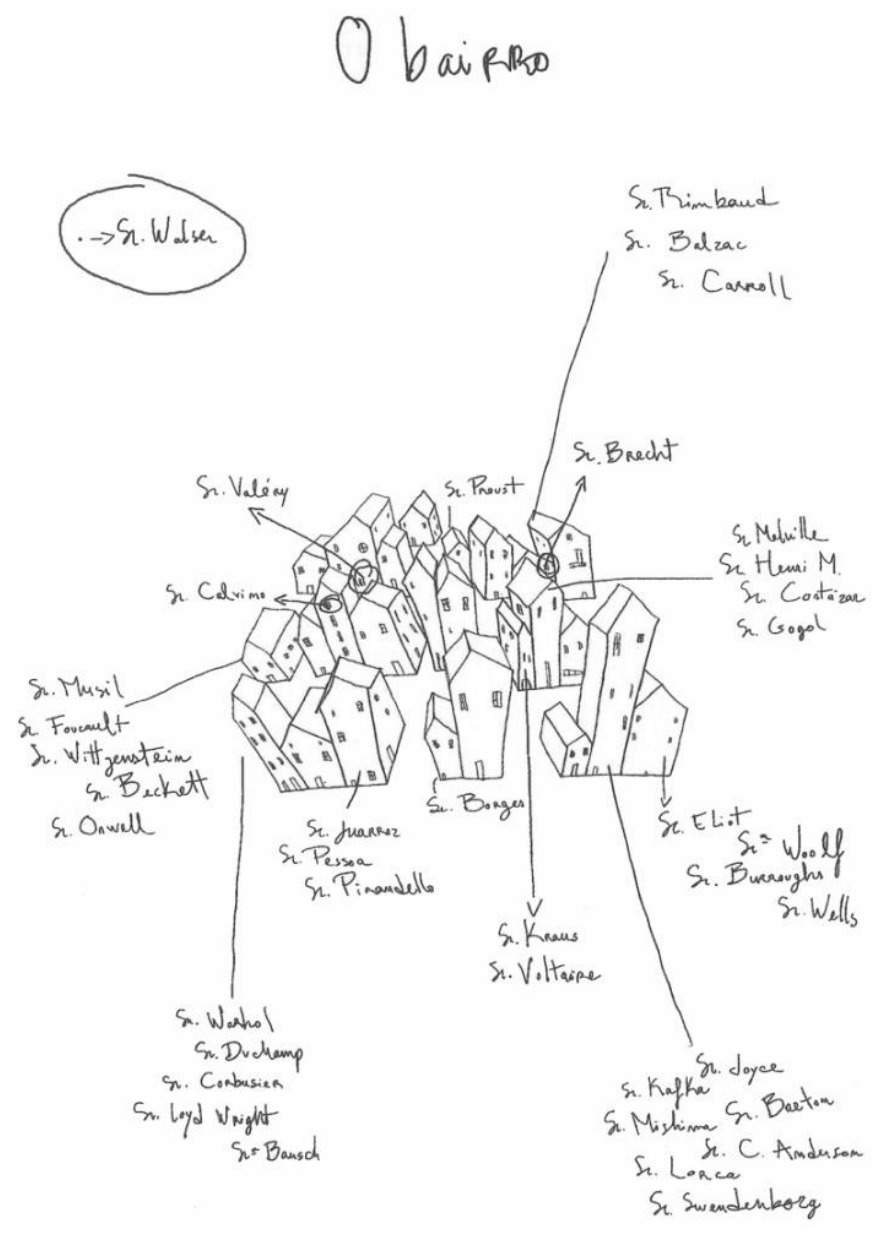

22 TAVARES, 2008, p. 12.

${ }^{23}$ Desenho de Rachel Caiano. In: TAVARES, Gonçalo M. O senhor Walser. Rio de Janeiro: Casa da Palavra, 2008, p. 5. 
Em um ambiente natural representado pelo bosque que rodeia sua nova morada, ele almeja encontrar alguém. Todavia, devido a problemas de construção, inicia-se uma interminável reforma, que ele aceita como algo inexorável. O futuro idealizado por ele aos poucos se esfarela em uma série de consertos, metaforizando a própria desintegração do tempo e do espaço de que fala Giddens (2002, p. 10), mencionada anteriormente neste trabalho.

Conforme afirma Bakhtin, o que no cronotopo idílico denota a aproximação entre homem e natureza, a ligação íntima entre espaço e tempo, isto é, a conexão da vida e dos seus acontecimentos com os espaços nos quais ocorre, representa em 0 senhor Walser (TAVARES, 2008), um rompimento, no qual o ambiente circundante e o tempo da esperança não têm valor algum em termos da sua concretização a partir de um dado momento.

De acordo com o teórico russo,

Outra particularidade do idílio é a sua estrita limitação às poucas realidades básicas da vida. $\mathrm{O}$ amor, o nascimento, a morte, o casamento, o trabalho, a comida e a bebida, as idades - esses são os fatos reais básicos na vida idílica. Eles são contíguos no exíguo microcosmo do idílio, entre eles não há contrastes rigorosos, eles têm valor igual [...].Às convenções sociais, à complexidade e à segmentação da vida privada, se opõem aqui a simplicidade completamente convencional da vida no seio da natureza; essa mesma vida se reduz ao amor totalmente sublimado (BAKHTIN, 1988, p. 334, sublinhado nosso).

O romântico senhor Walser age sempre no sentido de ter uma companheira e amigos com quem possa compartilhar 0 lar tão confortavelmente arranjado. O corolário dos seus ideais de homem sozinho, concretizado na casa recém-terminada, significa para ele, em última instância, alcançar o convívio almejado, realizar o encontro com o Outro, desfrutar de uma convivência capaz de Ihe preencher a vida de modo afetivo e amigável, revelado em monólogo interior: 
[...] a cordialidade, $\mathrm{o}$ aperto de mão entre dois homens que se entendem depois de uma longa conversa argumentada, um abraço comovido de uma despedida e, eventualmente, quem sabe - [...] um beijo apaixonado, o encontrar de uma companhia definitiva (TAVARES, 2008, p. 14, sublinhado nosso).

Até o sentido do tato é estimulado quando o senhor Walser passa a mão pelas paredes da casa, como a sentir a materialidade do sonho realizado, comportando-se como uma criança ao beber água diretamente da torneira, tal como o puer senilis ${ }^{24}$ de que fala Curtius (1996, p. 144-145).

Na cozinha, Walser passeia a mão curiosa pelos ladrilhos da parede. [...]. Abriu então a torneira e sem utilizar qualquer copo, inclinando como na infância o pescoço, bebeu a mais saborosa áqua de que se recordava. Com a mão limpou os pingos que lhe caíam do queixo e quase soltou um urro de contentamento por aquele tempo, finalmente, de clara solidão. Por ali, nem um único ruído de homem [...]. (TAVARES, 2008, p. 21, sublinhado nosso).

Assim, após a conquista da casa, ele redige, então, a carta que há tempos desejava mandar, dirigida a Thereza M.:

Nas suas linhas descreve, de modo contido, o espaço, e convida-a, com os mais recatados termos, para uma visita. Quanto tempo demorou a escrever aquela carta? Muito. Cada palavra no seu sítio, escrita cada letra como se da sua forma dependesse a própria estrutura da casa, as suas fundações (Idem, p. 22).

É de salientar que, de todos os senhores da série, ele é o que tem, de forma consciente, não apenas o anseio pelo encontro com o Outro, mas também é quem toma as medidas necessárias para propiciar a realização do

\footnotetext{
${ }^{24}$ Puer senilis ou puer senex, do latim: ancião-menino. (Nota da autora.)
} 
desejo. Todavia, o encontro que se configura real é o que se dá com os especialistas dos consertos, representando o oposto do que ele imaginara.

A alegria claramente manifesta por Walser pelo término da casa é interrompida pelo toque da campainha: "Que se passa? - murmura Walser. É a torneira da casa de banho - disse o homem. E entrou" (Ibid., p. 23).

E assim, sucessivamente, os profissionais se apossam do espaço de Walser, o que o leva a refletir: "Ele queria começar uma coisa, e aquele homem como que se interpunha. Bem intencionado, é certo, mas entre uma nova vida e Walser estava agora um obstáculo concreto - o encanador" (Ibid., p. 28).

Um após outro, sucessivamente, tomam de assalto a casa, alguns até de modo rude, como se os problemas tivessem sido causados pelo dono e não por eles próprios, e a quem não precisassem justificar sua presença e seus erros, investidos que estão do papel de especialistas. O Outro, representado agora pelos profissionais intrusos, não é o Outro almejado inicialmente pela personagem.

Assim, tanto o cronotopo idílico como também o cronotopo do encontro, ambos ainda em potencialidade latente, se transformam no cronotopo da sala de visitas do senhor Walser, tornando-se, ao final, o cronotopo do limiar.

A princípio, o paciente senhor Walser vê com bons olhos as intervenções inesperadas: "Entre, caro senhor, termine à vontade o seu trabalho... Que nada fique a meio - gracejou Walser para quebrar o silêncio, mas de resposta só obteve um informe murmúrio de concordância" (Ibid., p. 25).

Pouco depois, ele aceita que os homens pernoitem ali, já que não há tempo para consertar tudo num só dia: "O primeiro homem a pedir permissão para dormir ali na casa de Walser naquela noite foi um dos eletricistas. Depois, muitos outros repetiram o pedido" (Ibid., p. 45).

A falência do projeto da personagem, ao menos temporariamente, a perda da noção de sua pessoa, e os desconfortos por que passa levam à reflexão sobre a questão identitária e a construção de um ideal de vida, no período que antecedeu a contemporaneidade. 
Segundo Bauman,

Em grande parte como essa ordem global que coletivamente subscreveu os esforços individuais pela vida (abrangente, coesa, coerente e contínua), a identidade do indivíduo foi lançada como um projeto, o projeto de vida [...]. A identidade devia ser erigida sistematicamente, de degrau em degrau e de tijolo em tijolo, seguindo um esquema concluído antes de iniciado o trabalho. A construção requeria uma clara percepção da forma final, o cálculo cuidadoso dos passos que levariam a ela, o planejamento a longo prazo [...]. [...] um vínculo firme e irrevogável entre a ordem social como projeto e a vida individual como projeto, [...] (BAUMAN, 1998, p. 31, sublinhado nosso).

De modo aproximado, a citação reflete os acontecimentos da vida do senhor Walser, que, vivendo em um período posterior ao que é descrito por Bauman, isto é, uma época de ruptura com a organização e o planejamento de um projeto pessoal e de vida em sentido amplo, tem seus anseios frustrados e a própria identidade questionada: "[...] Walser esquecera-se, de certa maneira, de si próprio" (TAVARES, 2008, p. 35).

O senhor Walser perde a clareza de começo e fim, o que se revela pela menção, em monólogo interior, do início das histórias infantis, tempo marcado claramente pelo "era uma vez" (p. 28), que ele deseja a todo custo recuperar. Tal balizamento temporal torna-se agora distante no espaço; o que deveria ser sincronicamente assinalado pela passagem de um tempo, sobre o qual se deveria ter algum controle, não ocorre. O mal-estar da personagem pode ser explicado a partir do pensamento de Giddens:

A razão providencial - a ideia de que o aumento da compreensão secular da natureza das coisas intrinsecamente leva os seres humanos a uma existência mais segura e satisfatória - carrega resíduos de concepções do destino derivadas de eras pré-modernas. [...]. Aceitar o risco como risco, orientação que nos é mais ou menos imposta pelos sistemas abstratos da modernidade, é reconhecer que nenhum 
aspecto de nossas atividades segue um curso predestinado, e todos estão expostos a acontecimentos contingentes (GIDDENS, 2002, p. 33, sublinhado nosso).

A invasão e o controle dos profissionais sobre Walser estabelecem igualmente um intertexto com obras nas quais o homem perde o comando sobre a sua própria vida, como em $\mathbf{O}$ admirável mundo novo, de Aldous Huxley. O sonho desfeito de Walser se coloca igualmente em oposição a outra obra, O Emílio, de Jean-Jacques Rousseau, em que o contentamento, a cordialidade e o convívio amigável com a natureza representam um ideal de vida semelhante aos anseios daquele senhor.

A carência do Outro, que Walser esperava ver suprida por uma companheira e amigos num ambiente idealizado é, assim, destruída pelo Outro invasivo. Todavia, sendo um eterno otimista, a narrativa termina com a personagem conformada com aquela situação de desconforto, adormecendo de cansaço no chão do corredor, enrolado em um cobertor, encostado a uma parede da qual tinha sido removido o rodapé, à luz de uma vela, sem água, e impossibilitado de reconhecer a sua própria casa, tal a descaracterização representada pelos consertos. "[...] Walser, finalmente, depois de um dia tão longo, e embora cheio de sede, adormeceu tranquilo, pensando no dia seguinte" (TAVARES, 2008, p. 47).

Todos esses percalços não impedem, contudo, que o senhor Walser tenha, ainda, e apesar de tudo, esperanças. 


\section{3 Poder e denúncia: o senhor Brecht e o senhor Kraus}

"Um homem que tinha muito medo de todos os animais que rastejavam decidiu (por fim) ir viver em uma montanha muito alta" (O senhor Brecht $)^{25}$.

"Os políticos, quando beijam velhos cidadãos, lembram a primeira dentada tímida do verme no corpo que já não tem meios para a fuga nem porta de saída" (0 senhor Kraus) ${ }^{26}$.

Estes dois senhores têm em comum o fato de usarem suas vozes para expor as mazelas da contemporaneidade, que afetam de maneira profunda 0 homem comum, o núcleo familiar e as comunidades.

O senhor Brecht, contador de histórias, e o senhor Kraus, jornalista, cronista e satirista, usam ambos do recurso da denúncia no âmbito social, econômico e político, falada, por parte do senhor Brecht, e escrita, por parte do senhor Kraus, para fazer emergir aos olhos e às consciências dos seus ouvintes e leitores, os desmandos, os abusos e os malfeitos das esferas do poder.

No caso do senhor Brecht, uma plateia quase inexistente ouve seus relatos, narrados de forma impessoal, como se ele os estivesse lendo a partir de um livro. Ao narrar, o senhor Brecht desenvolve e perpetua uma atividade ancestral humana, a da narrativa oral.

Este é também seu modo de aproximar-se do Outro, não diretamente, mas pela via transversa das histórias que conta, e que retratam as angústias, os medos, e os posicionamentos nem sempre confortáveis do homem contemporâneo, entre os quais ele se inclui, colocando-se de modo intencionalmente distanciado do seu público ouvinte, possivelmente para não correr o risco da interpelação ou da troca interpessoal.

25 TAVARES, 2005, p. 58.
26 TAVARES, 2007b, p. 109. 
Algumas histórias do senhor Brecht poderiam ser encaixadas no gênero fantástico, no qual, segundo Todorov, um acontecimento inexplicável ocorre num mundo como o nosso.

De acordo com o autor,

[...] produz-se um acontecimento que não pode ser explicado pelas leis deste mesmo mundo familiar. [...]. [...] ou se trata de uma ilusão dos sentidos, de um produto da imaginação e nesse caso as leis do mundo continuam a ser o que são; ou então o acontecimento realmente ocorreu, é parte integrante da realidade, mas nesse caso esta realidade é regida por leis desconhecidas para nós (TODOROV, 2004, p. 30-31, sublinhado nosso).

É o caso da narrativa "A viúva", na qual, durante um velório, o morto sofre um gradual processo de encolhimento, a ponto de restar apenas o caixão. O conteúdo, no caso, o defunto, praticamente desaparece, restando apenas o elemento continente, o esquife:

Mediu o morto e confirmou o fato: a morte encurtara-lhe as pernas. O resto do corpo permanecia igual, mas as pernas haviam encurtado quinze centímetros, e apenas em duas horas. Mais tarde o fenômeno acelerou. No dia seguinte $o$ morto era já composto apenas por uns sapatos pretos novos e pela cabeça (TAVARES, 2005, p. 31).

Tal fato gera na viúva grande irritação e, surpreendentemente, nenhum espanto, residindo seu desgosto no fato de ter desperdiçado grande soma de dinheiro para adquirir o enorme caixão de madeira: "A minha madeira, a minha querida madeira! - murmurava ela, sem que ninguém a ouvisse. No dia do enterro, a viúva não suportou mais e, à frente dos familiares, desatou a chorar, agarrada à madeira do caixão" (Idem, p. 31).

No evento inusitado, segundo Todorov (2004, p. 31), "Há um fenômeno estranho que se pode explicar de duas maneiras, por meio de causas de tipo natural e sobrenatural. A possibilidade de se hesitar entre os dois criou o efeito 
fantástico". Como na narrativa do senhor Brecht não há um desfecho para a história, ou uma contextualização prévia, que indique tratar-se de um tempo/espaço, no qual, coisas sobrenaturais se inserem em um cotidiano aparentemente normal, o leitor fica preso às duas hipóteses. Para Todorov,

O fantástico ocorre nesta incerteza: ao escolher uma ou outra resposta, deixa-se o fantástico para se entrar num gênero vizinho, o estranho ou o maravilhoso. $\underline{O}$ fantástico é a hesitação experimentada por um ser que só conhece as leis naturais, face a um acontecimento aparentemente sobrenatural (Idem, p. 31).

Em "A viúva", não há hesitação ou surpresa no fato de o defunto encolher até sumir, nem por parte da esposa do morto nem da família, isto é, nada há que seja informado ao leitor a partir do narrador onisciente, e que explique as causas da estranha ocorrência. $O$ estranhamento decorre do fato tal qual descrito: o encolhimento gradativo do morto, a exatidão numérica do grau de encolhimento - quinze centímetros - o apego da viúva ao que é material, ou seja, o preço pago pela madeira do caixão, e não a tristeza pela morte do marido.

O senhor Kraus, por sua vez, escreve crônicas para um jornal, tendo como alvo principal os políticos venais. Para atingir seus objetivos de denúncia e crítica, ele cria personagens representativas deste meio, as quais, ao desempenhar papéis caricaturais, satirizam a política institucionalizada, a corrupção, os desmandos governamentais, a postura de falsa seriedade dos representantes do povo, incluindo-se aí as manipulações, as decisões motivadas por interesses espúrios, os lobbies, as estatísticas distorcidas, as pesquisas eleitorais realizadas sem lisura, as votações para cargos eletivos, as instâncias de poder corrompidas, e a imoralidade política em geral.

A principal personagem, representativa da classe política corrupta, é denominada de "o Chefe". Os assessores são chamados de "os Auxiliares", e o povo, vítima dos abusos governamentais, é simplesmente tratado pelo Chefe e por seus Auxiliares de "os Outros". Em geral, e em que pese a gravidade das 
denúncias feitas de modo satírico, mas contundente pelo senhor Kraus, o tipo de trabalho que ele exerce o deixa feliz.

Comunicativo quando fala com o Outro, o senhor Kraus, na verdade, fala para si. Suas relações com a alteridade são de natureza indireta, mediadas por sua profissão. Sua principal forma de aproximação com o Outro se dá, assim, por via do serviço que presta à população graças às crônicas políticas que publica, estabelecendo-se, dessa forma, a ponte com o Outro - o seu leitor - a qual não ocorre no plano afetivo. De toda maneira, em ambos os casos, o senhor Kraus nunca abandona a formalidade do seu status de cronista e homem da imprensa.

Estabelece-se, assim, a partir da postura do jornalista, certo nível de incomunicabilidade e distanciamento entre ele e a alteridade. Revelando sua natureza dual, quando eventualmente encontra um de seus vizinhos, ele fala ininterruptamente de assuntos ligados à vida política, sempre em tom crítico, sem se importar com o que pensam os seus interlocutores.

Em certa ocasião, dá-se o encontro com o senhor Breton, que, cansado da opressiva entrevista, e desejoso de espairecer e conversar se depara com o jornalista ao sair para a rua. Segundo o narrador onisciente,

O senhor Kraus tinha uma certa tendência para dominar por completo uma conversa. Passou logo para as mãos do senhor Breton o jornal que trazia. Ouviu falar daquela súbita troca de lugares entre ministros? - perguntou o senhor Kraus. [...]. Leia o artigo que publiquei hoje (TAVARES, 2009, p. 32).

O senhor Breton, que ansiava por uma conversa leve, de modo a desanuviar a cabeça dos cansativos questionamentos do entrevistador, sentese obrigado a ler o texto do senhor Kraus:

Especialistas no Universo não são apenas os astrônomos, há ainda os políticos./ Admiro esses especialistas da pólis, que certamente estudaram com lonesco./ Terão feito em dois fins de semana longos um pormenorizado doutoramento em tudo?/I A competência, excelência, é uma coisa vasta e grande como o Universo./ A competência individual, excelência, vai daqui até 
ali./ Consegue ver, daqui, excelência, sua competência?/ É grande e vasta como o mundo, disse alguém. Precisamente. [...] (Idem, p. 32-33, grifo do autor, sublinhado nosso).

O papel de denunciar malfeitos sociais e institucionais dos senhores Brecht e Kraus ocorre em níveis distintos. O senhor Brecht recorre a narrativas em que se observa uma crueza explícita, que expõe as relações sociais entre dominador e dominado, algoz e vítima, poderosos e fracos, sem meias palavras. Já as matérias para o jornal, as anotações e os comentários do senhor Kraus, por seu turno, contêm toques de ironia e humor velado, ambientadas que são as crônicas nos gabinetes escusos do poder.

Quanto ao senhor Brecht, várias das suas histórias acontecem no cronotopo do limiar, de grande densidade emocional e característico dos momentos de crise, conforme abordado no Capítulo I. Este é também o cronotopo que pode ser caracterizado, em Gonçalo M. Tavares, como o da violência extrema, atingindo não somente as pessoas, mas também os animais, como se pode notar em "A morte em L", na qual se mesclam certo humor negro associado à crueldade explícita. Nela, um cavalo de corrida se move como a peça homônima do xadrez:

Dois passos numa direção seguidos de um passo lateral. Acabava as corridas cinco horas depois de o último espectador ter saído. Para as corridas era óbvio que não servia, e era demasiado grande para ser aceito num tabuleiro com as dimensões oficiais. $\mathrm{O}$ dono teve de abatê-lo. $\mathrm{O}$ animal era resistente. Foram três tiros. Dois numa direção e o terceiro lateralmente a estes (TAVARES, 2005, p. 46, sublinhado nosso).

Procede-se, assim, à eliminação sumária do que não se encaixa no paradigma conhecido, figurativizando, em todos os casos, nonsensical solutions, metáforas da violência cotidiana e da conformação dos indivíduos a ela. Nas narrativas do senhor Brecht, as personagens que detêm o poder tomam decisões baseadas em expurgos do que julgam ser inconveniente; aos 
fracos só resta aceitar, complacentemente, tais decisões, participantes submissos a quem não cabe decidir.

Tal conformação frente às adversidades é levada ao paroxismo, sem possibilidade de redenção, o que envolve a aquiescência, por parte das vítimas aterrorizadas, do que não pode ou não deve ser questionado, no caso, o sistema oficial, as leis draconianas do poder estabelecido, os poderosos de fora e de dentro do sistema.

Já em 0 senhor Kraus (TAVARES, 2007b), é possível notar o tratamento cômico-reducionista do jornalista em relação à simbólica e fictícia personagem, representação emblemática do político ignorante, sem escrúpulos, a quem falta senso crítico e sobra vaidade. Nas palavras do narrador onisciente,

O Chefe estava no seu gabinete calmamente a andar de um lado para o outro a grande velocidade em redor da sua mesa, entretendo-se a arrancar, de tempos a tempos, com violência, um dos seus cabelos, ao mesmo tempo que controlava o seu urro de dor, numa espécie de jogo consigo próprio, que ele mesmo classificava como "quase divertido" [...] (Idem, p. 12, grifo do autor, sublinhado nosso).

Os ruídos são, de fato, as vozes dos Auxiliares, designados como $1^{\circ}$ Auxiliar e $2^{\circ}$ Auxiliar, aduladores fervorosos do Chefe, mas que o irritam profundamente: "O Chefe estava já cansado de entrar em desespero com o auxílio daqueles homens. Tinha o direito de entrar em desespero sozinho, como um verdadeiro Chefe" (Ibid., p. 13). Notando que algo de grave ocorre, e emulando as estátuas dos ditadores,

$\underline{\mathrm{O} C h e f e}$ endireitou-se, levantou o braço e com o dedo indicador apontou para cima. Gostava deste gesto; sentia-se a determinar o caminho à população. [...]. É para cima, o caminho é para cima - parecia dizer o Chefe, com aquele gesto de braço levantado e dedo indicador esticado. E como a população nos últimos minutos não lhe saía da cabeça, sentiuse comovido e espantado consigo próprio. Ele, que antes de ser Chefe nunca, mas nunca, pensara na população, estava 
agora com os pensamentos totalmente embrenhados nela; na população (que nunca conhecera). Isto aprende-se, murmurou (Ibid., p. 15, sublinhado nosso).

Diante da vaidade dos políticos, comenta o senhor Kraus: "Quando o político nos fala do céu, e aponta o dedo para o alto dizendo, vêem?, é aí, nesse momento, que devemos olhar atentamente para os objetos que ele guarda na cave" (Ibid., p. 83).

As ações do Chefe são marcadas pela ignorância em relação à população que o elegeu, como também pelo desacerto das decisões que visam apenas propagandear os seus "feitos", sem qualquer preocupação pela qualidade e/ou pelos benefícios que possam, eventualmente, trazer ao povo.

Tais atos e decisões são catalisados pela adulação incondicional dirigida pelos Auxiliares ao Chefe, o que acaba por fazê-lo crer que é um ótimo político. Vaidoso, o Chefe é também capaz de autoelogios pelas razões mais despropositadas. Ao trancar-se no escritório, sozinho, para que pensem que está em reunião, o Chefe prossegue em seus pensamentos autoelogiosos:

$\underline{\text { Se ele era o Chefe, portanto o ponto máximo, pensar de si para }}$ si próprio era ou não importante? Aliás, sozinho conseguia fazer, de longe, a mais importante das reuniões. Para se sentir mais convincente, quando apresentasse a justificação para a porta fechada, começou a falar sozinho, como se discutisse com um seu qualquer pensamento anterior (Ibid., p. 14, sublinhado nosso).

Paralelamente ao seu horror ao povo, fica também patente a sua ignorância em todas as áreas, não apenas no campo político. Segundo a descrição do narrador onisciente, à maneira das enumerações rabelaisianas, "O Chefe detestava geografia, economia, literatura, química, sociologia, engenharia, matemática, física, e ainda todas as ciências inventadas depois de Cristo. O que ele apreciava era o instinto" (Ibid., p. 19). 
Assim, a racionalidade e a ponderação, bem como o conhecimento, não estão entre as qualidades do Chefe como gestor político. Todavia, ele gosta de dar explicações, desafiadoras de qualquer lógica, exceto a sua própria.

Uma demonstração dos seus equívocos governamentais tem lugar quando um dos Auxiliares dá a ele uma ideia brilhante:

A ideia é a seguinte, senhor Chefe. Fazemos duas pontes, de vários quilômetros, uma ao lado da outra. Cada uma delas só terá um sentido. Numa ponte os carros vão para lá, na outra os carros vêm para cá. Que the parece? Lado a lado, com distância entre elas de menos de cinquenta metros. Dá para dizer adeus de uma para a outra. Seriam como duas pontes irmãs. Duas pontes inéditas na Europa! E mesmo no mundo. No mundo[!] (Ibid., p. 31, sublinhado nosso).

Como a demonstrar preocupação com o povo, algo que, na verdade, não ocorre com o Chefe, ele faz um jogo de aparências diante dos Auxiliares, explicando uma artimanha óbvia:

O Chefe abanou a cabeça e apostou num longo silêncio. Depois, com voz grave, disse: Ainda antes das soluções engenhosas deve estar a preocupação com o dinheiro que se gasta. Porque o dinheiro não é nosso, é da população. [...]. Sendo assim, em vez de duas pontes proponho que se faça uma apenas, com os dois sentidos - disse o Chefe. [...] Passamos os gastos pela metade - acrescentou. [...]. Para que a população veja como zelamos pelo dinheiro comum (Ibid., p. 31-32, sublinhado nosso).

Assim, os interesses escusos e o poder ganham corpo na figura e nas iniciativas do governante, respaldadas pelo apoio incondicional dos assessores. Na falta de obras para inaugurar, o Chefe se sente nervoso: "Andava de um lado para o outro. Nada para inaugurar, nada [!] (Ibid., p. 38). De repente, o Primeiro Auxiliar tem uma ideia: "Alguma vez já veio a esta terra tão desagradável, friorenta, deserta, nojenta até, sob certo ponto de vista, mas tão prometedora[?]" (Ibid., p. 39). 
Diante da negativa do Chefe, vem a brilhante sugestão do mesmo assessor: "Podemos inaugurar a sua presença nesta terra. É a primeira vez que o Chefe vem a este espaço. Isso não é extraordinário[?]" (Ibid., p. 39).

O Chefe, sempre preocupado com a autopromoção, aprova de imediato a ideia:

Eu mesmo vou inaugurar a minha presença nesta terra!! Não é fácil - disseram os dois Auxiliares em coro. Inaugurar e ser a coisa inaugurada ao mesmo tempo... Foi então que, levantando vigorosamente o queixo em direção ao céu, o Chefe respondeu, de uma vez: Sou um homem que gosta de enfrentar as dificuldades. E era, de fato (Ibid., p. 39, sublinhado nosso).

Prosseguindo em sua lógica peculiar e invertida, o Chefe vai além: planeja também inaugurar algo que não tenha volume nem ocupe espaço, já que todas as coisas do lugar haviam sido inauguradas. Ele explica o seu plano aos atônitos Auxiliares, que não se cansam de se surpreender com as ideias fantásticas do Chefe:

A minha ideia é a seguinte: alguma vez nesta terra ocorreu este dia de hoje? [...]. Nesta terra, refiro-me apenas a esta terra - esclareceu o Chefe. Nunca, Chefe. É a primeira vez que este dia vem a esta terra. [...]. Podemos inaugurar este dia nesta terra. Eu inauguro o dia de hoje... É uma ideia impressionante, Chefe. Em vez de inaugurar espaços, inaugurar tempos, eis uma ideia importante, sem dúvida... [...] (Ibid., p. 40-41, sublinhado nosso).

Desse modo, ao Chefe sempre acodem ideias incríveis, tais como inaugurar a própria presença em um lugar a que nunca fora, ou o tempo - o hoje que nunca antes existiu -, o que se revela absurdo e imoral sob qualquer óptica, sempre no intuito de aparentar, mais do que fazer.

No caso das crônicas do senhor Kraus, é de se notar o viés paródico, além do satírico, que pontua as narrativas. Não apenas o jornalista usa da 
figura do Chefe para criticar os políticos venais, mas suas estratégias de ação, estendendo a sua reprovação a todos que orbitam em torno das esferas de governo. O despreparo do Chefe é análogo ao que se vê, muitas vezes, na realidade do mundo social da contemporaneidade, em todos os lugares e em todas as instâncias de poder.

Em se tratando das narrativas do senhor Brecht, temas como a vileza, a crueldade, a inexorabilidade, as situações de exceção, as utopias, os processos de dominação e manipulação, a censura, a burocracia, a corrupção, os sistemas políticos arbitrários são todos explorados nas histórias, bem como a arte, a poesia, a filosofia, o conhecimento, nas quais se incluem personagens sem nome e, portanto, desprovidas de identidade, a não ser por seus estatutos civis ou de profissão. Outras personagens são animais, os quais, como nas fábulas, falam e apresentam comportamentos inusitados.

Os problemas sociais e existenciais humanos das épocas pós-modernas aparecem nas narrativas do senhor Brecht por meio da criação de situações de absurdo e de paroxismo, sejam elas de ordem individual ou comunitária, tanto do ponto de vista das vítimas como dos algozes. Segundo Todorov, "Tal é o paradoxo da linguagem literária: é precisamente quando as palavras são empregadas em sentido figurado que devemos tomá-las literalmente" (TODOROV, 2004, p. 69).

Quanto às histórias narradas pelo senhor Brecht, a crueldade física é a ponte para se atingir sofrimentos psicológicos profundos, os quais, sem ser mencionados, emergem claramente nas narrativas, tal como ocorre em "Mau negócio". Nesta história, um casal principia a esfolar um porco para comer, tirando-Ihe a pele antes de matá-lo. "Mesmo antes de morrer o animal murmurou: Eu-não-sou-um-porco-sou-um-homem. O casal ajoelhou-se e pôsse a chorar. Este porco fala. Como seria rentável[!]" (TAVARES, 2005, p. 33).

É possível apreciar aí a perda de identidade do homem, que se declara homem e não um porco, contrariando a sua aparência, a qual reflete o modo como se sente. Aqui a linguagem retoma a identidade do homem que quer, embora submetido, afirmar-se como tal, em oposição ao desejo do casal de mantê-lo como um porco. Ao declarar-se homem, o indivíduo abandona, em tese, a posição de simulacro. O lamento da mulher refere-se não à morte do 
indivíduo, mas apenas à perda da possibilidade de lucro pela exibição do que é aberrante.

Para Foucault, os discursos que narram o medo e o terror - como é o caso das histórias do senhor Brecht -, não apresentam parentesco com a crueldade, nem há uma relação entre a literatura e o mal. Trata-se, para o autor, de algo mais obscuro e paradoxal. São "[...] linguagens [...] puxadas para fora de si mesmas pelo inumerável, o indizível, o estremecimento, o estupor, o êxtase, o mutismo, a pura violência, o gesto sem palavra e que são calculadas, com a maior economia e a maior precisão [...]. Essas linguagens [...] são linguagens curiosamente duplas" (FOUCAULT, 1963 apud MOTTA, 2006, p. 53).

Em outro relato do senhor Brecht, "Estética", "Uma mulher gorda que queria perder peso chegou ao médico e disse: Corte-me uma perna" (TAVARES, 2005, p. 28). Nota-se aí uma distorção da ideia original relativa à "perda de peso" com a finalidade de emagrecimento, e que na história adquire o significado de mutilação, mesmo que esta represente, em última instância, a pretendida redução ponderal. Nesse sentido, o título se coloca como antagônico ao significado imediato contido no texto, estando também implícita a questão da imposição do ideal físico e estético da contemporaneidade, o qual deve ser alcançado a qualquer custo.

A questão perturbadora da falta de estabilidade, presente nas narrativas do senhor Brecht, e que também ocorre com o homem contemporâneo, é comentada por Stuart Hall, ao mencionar o marco divisório existente entre o modelo sociológico, que ele denomina de "interativo", o qual predominou até meados do século passado, em contrapartida ao modelo estabelecido pela contemporaneidade. O padrão social "interativo",

[...] com sua reciprocidade estável entre "interior" e "exterior", é, em grande parte, um produto da primeira metade do século XX, quando as ciências sociais assumem sua forma disciplinar atual. Entretanto, exatamente no mesmo período, um quadro mais perturbado e perturbador do sujeito e da identidade estava começando a emergir dos movimentos estéticos $\mathrm{e}$ intelectuais associado com o surgimento do Modernismo. 
Encontramos aqui, a figura do indivíduo isolado, exilado ou alienado, colocado contra o pano de fundo da multidão ou da metrópole anônima e impessoal (HALL, 2006, p. 32, grifo do autor, sublinhado nosso).

Tal quadro está presente de maneira perturbadora nas narrativas do senhor Brecht, revelando as descontinuidades de que fala Giddens, citado por Hall:

Os modos de vida colocados em ação pela modernidade nos livraram, de uma forma bastante inédita, de todos os tipos tradicionais de ordem social. Tanto em extensão, quanto em intensidade, as transformações envolvidas na modernidade são mais profundas do que a maioria das mudanças características dos períodos anteriores. No plano da extensão, elas serviram para estabelecer formas de interconexão social que cobrem o globo; em termos de intensidade, elas alteraram algumas das características mais íntimas e pessoais de nossa existência cotidiana (GIDDENS, 1990 apud HALL, 2006, p. 16, sublinhado nosso).

A grande crítica do senhor Kraus é dirigida fundamentalmente ao Chefe, que representa, por analogia, a classe política corrompida. Todavia, certa porção de culpa é atribuída pelo jornalista aos eleitores, os quais, ainda que sejam vítimas da ardilosa propaganda dos políticos, não se empenham, por falta de tirocínio ou por comodismo, em escolher com maior discernimento seus candidatos. É o que se pode notar a partir do raciocínio do jornalista:

Quem dorme e quem corre? Por vezes não é fácil distinguir, disse o senhor Kraus. Colocar as pantufas ou os sapatos de atletismo. Eis as duas opções. Os políticos mais astutos são aqueles que até no momento em que calçam as pantufas parecem estar, afinal, em intensos preparativos atléticos. À origem de tal ilusão de ótica - murmurou o senhor Kraus poderá chamar-se propaganda ou miopia do observador (TAVARES, 2007b, p. 29, sublinhado nosso). 
$\mathrm{Na}$ anotação sob o título Pontualidade, outra crítica aguda é desferida contra o alvo costumeiro: "Há hábitos que jamais se abandonam. O bom político até à inauguração de um relógio chega atrasado" (Idem, p. 36).

Passadas as eleições, o senhor Kraus faz outro apontamento, que é também uma reflexão sobre a manipulação dos políticos em relação ao povo, sob o título Depois das eleições:

Depois de qualquer eleição a sensação dos políticos - quer tenham perdido quer tenham ganho - é a de que o povo mais profundo acaba de entrar todo num comboio, dirigindo-se, compactamente, para uma terra distante. Esse povo voltará apenas, no mesmo comboio, nas semanas que antecedem a eleição seguinte. Esse intervalo temporal é indispensável para que o político tenha tempo para transformar, delicadamente, 0 ódio ou a indiferença em nova paixão genuína (Ibid., p. 66, sublinhado nosso).

Estabelece-se aí uma relação intertextual com o Holocausto havido durante a Segunda Guerra Mundial, em que judeus e outros perseguidos pela Alemanha nazista eram levados à força para os campos de extermínio, amontoados em vagões como gado, em analogia ao uso vil que fazem os políticos dos seus eleitores, ignorando-os ou desprezando-os assim que terminam as eleições.

Mesmo nas épocas que as antecedem, o Chefe não dá nada aos que Ihe pedem algo. Na verdade,

O Chefe gostava de dar o exemplo. Mas tirando isso não gostava de dar nada a ninguém. Quando algum desgraçado se aproximava dizendo: Eu precisava de apoio para investir na minha empresa... O Chefe ia logo com a frase: Olhe, por exemplo... - e lá continuava num longo discurso onde, de fato, exemplificava. Quando o tal desgraçado voltava a casa, a mulher perguntava: Então, o Chefe? Deu-te apoio? E o homem respondia: Deu-me um exemplo. [...]. E era sempre assim. [...]. Em suma: não dava alimentos, não dava áqua, não dava cobertores, não dava uma lâmpada, um bocado de sal, um 
parafuso, nada, não dava nada a ninguém, nada! Dava apenas o exemplo (Ibid., p. 103-104, sublinhado nosso).

É possível observar, na enumeração acima, uma retomada do cronotopo rabelaisiano, em que são citadas, como em uma lista, as coisas que o Chefe não dá a ninguém, metaforizando a pessoa do Chefe o rei medieval ou de períodos posteriores, que só deseja e espera elogios dos subordinados, mesmo que falsos, distribuindo ao povo apenas migalhas. Os Auxiliares representam, metaforicamente, o bufão e o bobo, que falam apenas o que o rei deseja ouvir. Segundo afirma Mikhail Bakhtin, com relação a essas figuras,

[...] a própria existência dessas personagens tem um significado que não é literal, mas figurado: a própria aparência delas, tudo o que fazem e dizem não tem sentido direto $e$ imediato, mas sim figurado e, às vezes, invertido. Não se pode entendê-las literalmente, elas não são o que parecem ser; [...] (BAKHTIN, 1988, p. 275-276, grifo do autor, sublinhado nosso).

Assim, no âmbito da política, as relações Eu-Outro são sempre mediadas por mascaramentos e disfarces. O próprio senhor Kraus usa de chistes e ironias, fazendo ele próprio o papel do "bufão", que critica de modo velado o que não pode fazer abertamente, sendo a classe política criticada de forma geral por meio da personagem caricatural - o Chefe. Nesse sentido, a sátira, a paródia e os recursos de comicidade são os meios encontrados pelo jornalista para rebaixar e criticar disfarçadamente os verdadeiros alvos das suas denúncias.

De fato, o senhor Kraus tem consciência do alcance relativamente restrito que possui a mídia no sentido de advertir as pessoas dos perigos que podem representar certos políticos:

As eleições haviam terminado e o varredor há mais de duas horas que com a vassoura empurrava os boletins de voto para o canto da sala. Os boletins, agora inúteis, avançavam contra vontade, para o canto, como se fossem guardanapos sujos e não papéis determinantes para um certo país numa certa 
altura. Eram empurrados como lixo. O senhor Kraus observava todo o espetáculo, melancólico (TAVARES, 2007b, p. 64, sublinhado nosso).

$\mathrm{Na}$ visão de Giddens, os meios de comunicação, como reorganizadores do tempo e do espaço, representam a expressão de tendências que atuam globalmente, como também funcionam como instrumentos dessas tendências. Segundo ele,

[...] isso vale para as duas características básicas da experiência transmitida pela mídia nas condições da modernidade. Uma é o efeito colagem. Dado que o evento se tornou quase completamente dominante em relação ao lugar, a apresentação dos meios de comunicação toma a forma de justaposição de histórias e itens que nada têm em comum exceto serem "oportunos" e terem consequências. [...]. Muitos dos eventos relatados no noticiário, por exemplo, podem ser experimentados pelo indivíduo como exteriores e remotos [...] (GIDDENS, 2002, p. 31, grifo do autor, sublinhado nosso).

Bombardeado de todos os lados pelos meios de comunicação, o homem da contemporaneidade como que perde a capacidade de filtrar o relevante do corriqueiro, deixando, ao mesmo tempo, de levar em conta muitas das notícias que lê, vê e ouve, como se estas fossem peças ficcionais, aparentemente distanciadas da sua realidade cotidiana.

Para a maioria dos espectadores, problemas como os das minorias, dos excluídos sociais, dos perseguidos políticos, bem como outras questões relevantes não encontram eco ou espaço para uma reflexão mais aprofundada. Tal lógica de distanciamento e de isenção está contaminada igualmente por um individualismo exacerbado e excludente, presente também em várias das narrativas do senhor Brecht. Em uma delas, "O estrangeiro",

O homem entrou para o coro, mas insistia em cantar individualmente uma canção que só ele conhecia. O maestro, que gostava de integrar todas as pessoas, cheio de boavontade, pediu ao novo elemento para Ihes ensinar a canção. 
Esta, no entanto, era numa língua que mais nenhum elemento dominava. $\underline{O}$ homem explicou que, para cantarem com ele, teriam primeiro que aprender aquela língua. [...]. Passados dois anos os elementos do grupo estavam finalmente aptos a cantar [...]. Marcou-se a estreia, mas o homem não compareceu (TAVARES, 2005, p. 34, sublinhado nosso).

Tal processo encontra semelhança na questão identitária de grupo, como a descrevem filósofos e sociólogos, estudiosos das maneiras como se desenvolvem as relações dos indivíduos nas sociedades nacionais, em que se inserem outras culturas e indivíduos de diferentes países. No caso da história do senhor Brecht, o elemento "diferente" funciona como desintegrador do grupo como um todo, mas tal processo pode acontecer de maneira inversa, em que o grupo recusa o que não pertence originalmente a ele, sendo a língua falada pelo Outro uma das marcas de diferença e exclusão.

Stuart Hall assim define tais relações no âmbito das comunidades de diferentes países:

No mundo moderno, as culturas nacionais em que nascemos se constituem em uma das principais fontes de identidade cultural. Ao nos definirmos, algumas vezes dizemos que somos ingleses ou galeses ou indianos ou jamaicanos. Obviamente, ao fazer isso estamos falando de forma metafórica. Essas identidades não estão literalmente impressas em nossos genes. Entretanto, nós efetivamente pensamos nelas como se fossem parte de nossa natureza essencial (HALL, 2006, p. 47, sublinhado nosso).

O que à primeira vista parece ser um elemento agregador da identidade nacional, pode se revelar perverso nas questões relativas ao preconceito, por exemplo. Para Hall,

O discurso da cultura nacional não é, assim, tão moderno como aparenta ser. Ele constrói identidades que são colocadas, de modo ambíguo, entre o passado e o futuro. [...]. As culturas nacionais são tentadas, algumas vezes, a se voltar para 0 
passado, a recuar defensivamente para aquele "tempo perdido", quando a nação era "grande"; são tentadas a restaurar as identidades passadas. Este constitui o elemento regressivo, anacrônico, da estória (sic) da cultura nacional. [...] esse mesmo retorno ao passado oculta uma luta para mobilizar as "pessoas" para que purifiquem suas fileiras, para que expulsem os "outros" que ameaçam sua identidade [...] (Idem, p. 56, grifo do autor, sublinhado nosso).

As histórias do senhor Brecht contêm, ainda, um forte elemento de improbabilidade, o qual adquire um caráter trivial, como se eventos inusitados fossem rotineiros. Em "Defeito" predomina uma lógica paralela e casuística, determinante de uma ocorrência improvável, que acaba se tornando usual:

Por um curto-circuito elétrico incompreensível o eletrocutado foi o funcionário que baixou a alavanca e não o criminoso que se encontrava sentado na cadeira. Como não se conseguiu resolver o defeito, nas vezes seguintes o funcionário do governo sentava-se na cadeira elétrica e era o criminoso que ficava encarregue de baixar a alavanca mortal (TAVARES, 2005, p. 29).

A narrativa acima coloca condenado e executor em posições trocadas, como resultado de uma improbabilidade extrema, a qual obriga, sem que restem opções, a uma estranha e compulsória mudança de procedimento, por meio da qual se institucionaliza a anomalia e a inversão.

A dúvida e a hesitação, elementos pertinentes à realidade do homem contemporâneo, aparecem igualmente em outra história, ironicamente denominada "Liberdade de escolha": "Era uma livraria que vendia um único livro. Havia 100 mil exemplares numerados do mesmo livro. Como em qualquer outra livraria os compradores demoravam-se, hesitando no número a escolher" (Idem, p. 40).

Emerge aí a questão das opções, em uma sociedade, tal como a contemporânea, na qual as múltiplas possibilidades de escolha tendem a induzir à ideia de ampla liberdade. $\mathrm{O}$ que supostamente são decisões livres e 
pessoais tem origem nas manipulações exercidas pelos interesses mercadológicos e pela mídia, quando não, nas imposições dos regimes de força, em que a numeração dos exemplares remete aos mecanismos de controle oriundos das esferas de poder.

O contador de histórias indiferente, impessoal e distante, representado pelo senhor Brecht, confere o tom final de cinismo e ironia, de quem narra a dor, a mutilação e o sofrimento como quem conta uma história banal. De certo modo, é como se ele, ao não demonstrar qualquer emoção, estabelecesse uma barreira entre a sua pessoa e o sofrimento narrado, protegendo-se da dor e do risco de estar envolvido com o Outro, e que constitui, em última análise, o temor que aflige não apenas a esse senhor, mas de maneiras diversas, a todos os demais. 


\section{4 O medo e o método: o senhor Valéry e o senhor Juarroz}

"No fundo - disse o senhor Valéry, enquanto fazia outro desenho - devemos juntar-nos, sim, àquilo precisamente que não gostamos de ser, para assim nos conseguirmos transformar no que pretendemos" (O senhor Valéry $)^{27}$.

"O senhor Juarroz estava a pensar que o mundo andava dessincronizado pois de um lado havia inundações e do outro pessoas com sede, quando finalmente começou a prestar atenção ao ruído de uma torneira a pingar" ( $O$ senhor Juarroz $)^{28}$.

O senhor Valéry é outro dos senhores que compõem a série, possivelmente o mais esforçado deles em suas tentativas de encontrar soluções para os problemas que o incomodam, como a sua baixa estatura:

O senhor Valéry era pequenino, mas dava muitos saltos. Ele explicava: Sou igual às pessoas altas só que por menos tempo. Mas isto constituía para ele um problema. Mais tarde o senhor Valéry pôs-se a pensar que, se as pessoas altas saltassem, ele nunca as alcançaria na vertical. E tal pensamento desanimou-o um pouco. Mais pelo cansaço, no entanto, do que por esta razão, o senhor Valéry um certo dia abandonou os saltinhos. Definitivamente. Dias depois saiu à rua com um banco. Colocava-se em cima dele e ficava lá em cima, parado, a olhar. Desta maneira sou igual aos altos durante muito tempo. Só que imóvel (TAVARES, 2004a, p. 7, sublinhado nosso).

A busca do senhor Valéry pela outridade inclui assumir este Outro como paradigma. Ao sair à rua, e por julgar-se baixo, as pessoas passam a ser o seu modelo. As soluções mirabolantes que propõe para resolver o que considera um problema só o afastam do Outro. Diante do impasse entre os saltos e o uso do banquinho, o senhor Valéry toma uma nova decisão:

27 TAVARES, 2004a, p. 79.
28 TAVARES, 2007a, p. 35. 
O senhor Valéry fez então vários cálculos e desenhos. Pensou primeiro num banco com rodas, e desenhou-o. Pensou depois em congelar um salto. Como se fosse possível suspender a força da gravidade, apenas durante uma hora (ele não pedia mais), nos seus percursos pela cidade. E o senhor Valéry desenhou o seu sonho, tão comum ${ }^{29}$ (Idem, p. 8-9, sublinhado nosso).
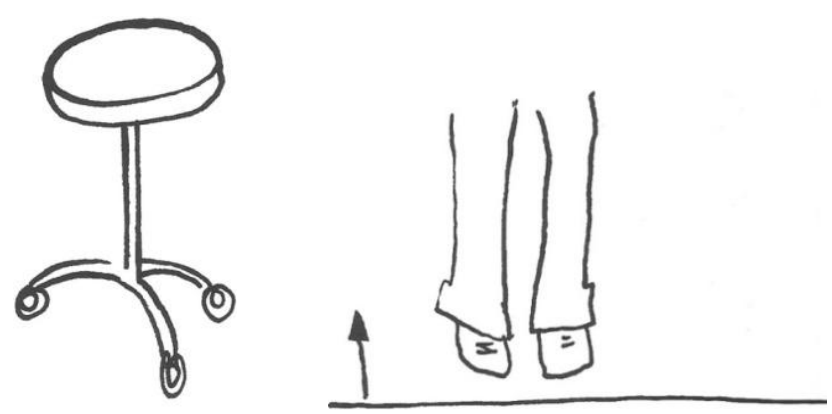

Eminentemente gráfico e visual, o senhor Valéry necessita demonstrar, por meio de esquemas e desenhos, os raciocínios que o levam a determinada atitude ou decisão. Eles são também a representação concreta, que corrobora e justifica suas explicações, desafiadoras da lógica formal, mas que buscam tornar inteligível o inexplicável, ao mesmo tempo em que concretizam alternativas naturais para este senhor, embora absurdas se observadas pelo olhar comum. Por fim, ao ver que nenhuma das pouco ortodoxas medidas iria funcionar, ele toma uma importante resolução:

[...] por isso o senhor Valéry decidiu ser alto na cabeça. Agora, quando se cruzava com as pessoas, na rua, concentrava-se mentalmente, e olhava para elas como se as visse de um ponto 20 centímetros mais acima. [...]. O senhor Valéry nunca mais se lembrou das hipóteses do banco ou dos saltinhos, considerando-as agora, a uma certa distância, ridículas. Porém, concentrado de tal modo nesta visão, como que de cima, tinha dificuldade em se lembrar da cara das pessoas com

${ }^{29}$ Desenhos de Rachel Caiano. In: TAVARES, Gonçalo M. O senhor Valéry. Porto Alegre: Escritos, 2004a, p. 8-9. 
quem se cruzava. No fundo, com a altura, o senhor Valéry perdeu amigos (Ibid., p. 9-10, sublinhado nosso).

Como os demais senhores, o senhor Valéry apresenta peculiaridades comportamentais e de pensamento, as quais, todavia, não são os únicos elementos a pautar o seu modo de ser. Como também é seu anseio o encontro com o Outro, a inconveniência de ser mais alto do que as outras pessoas funciona em sentido inverso ao desejado, já que, concentrado em vê-las de cima, não olha para os seus rostos, não as cumprimenta, nem sabe com quem cruza em seus passeios.

Tal como os outros senhores que, em medidas e segundo estratégias distintas, desejam chegar ao Outro, mas temem o sofrimento da perda, também o senhor Valéry se sente em um impasse entre a aproximação e uma eventual dor futura. No caso do seu animal de estimação, é possível perceber, conforme mencionado no Capítulo I, a forma peculiar com que lida o senhor Valéry com o seu pet: preso permanentemente em uma caixa com dois furos, um para alimentação e o outro para limpeza, o não relacionamento é a garantia de que o dono não sofrerá ao perdê-lo. "E dizia: "Quem poderá ganhar afecto por uma caixa[?]”30 (Ibid., p. 12).

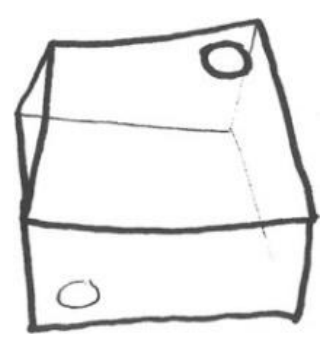

O senhor Valéry, do mesmo modo que imagina ser mais alto, também crê ter uma esposa. Seu relacionamento imaginário é, em suas palavras, com um "ser ambíguo" (p. 33), um constructo amorfo, que faz o papel de cônjuge.

${ }^{30}$ Desenhos desta e da página seguinte de Rachel Caiano. In: TAVARES, Gonçalo M. 0 senhor Valéry. Porto Alegre: Escritos, p. 12 e 33 e 34, respectivamente. 


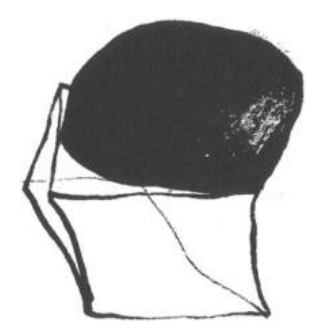

Assim, "Quando o senhor Valéry precisava de algo a que podemos chamar $X$, o ser era $X$; e quando precisava de algo a que podemos chamar $Y, 0$ ser era $\mathrm{Y}$. O casamento funcionava porque o senhor Valéry só tinha duas vontades" (Ibid., p. 33). Ele então prossegue em seu esforço de tornar mais claro o aspecto físico da suposta esposa: "[...] o ser com quem casei é assim (e desenhava)" (Ibid., p. 33).

"Se fosse só assim cansava-me" (Ibid., p. 34).

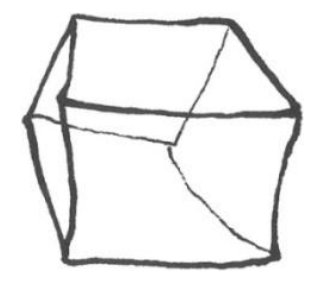

"E se fosse assim entediava-me" (Ibid., p. 34).

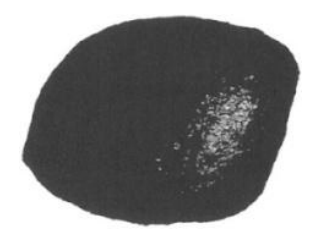

Ele então finaliza: "Felizmente - dizia o senhor Valéry - há cubos e esferas imperfeitas. E num raro trocadilho de palavras, concluía, irónico: E isso, para mim, é perfeito. Porém nunca ninguém tinha visto o senhor Valéry acompanhado" (Ibid., p. 35).

De fato, a "esposa" a que o senhor Valéry se refere é "algo" que se amolda às suas vontades, e, pelas diferentes possibilidades de combinação da esfera e do cubo, é capaz de evitar que ele sinta a monotonia de ver sempre a 
mesma coisa. A segurança de que precisa este senhor emana sempre da sua imaginação, nunca da realidade circundante, e, preferencialmente, deve ser concretizada em formas geométricas simples. Até mesmo as suas vontades são matematicamente representadas por incógnitas: $\mathrm{X}$ e $\mathrm{Y}$.

O mundo esquematizado, desenhado e previamente mapeado, é tudo de que esse senhor necessita para se sentir um indivíduo compreendido e aceito.

No caso do cônjuge idealizado, observa-se um processo de desantropomorfização simbólica, ou seja, a representação imagética simultânea do desconhecimento e do distanciamento do senhor Valéry em relação à alteridade - imaginada ora como cubo, ora como esfera, ou as duas formas ao mesmo tempo. Ao transformar a "esposa objeto" em algo utilitário, tal como um aparelho eletrodoméstico, o senhor Valéry elimina quaisquer possíveis laços emocionais, tanto para o prazer como para a dor.

Servindo-se de recursos gráficos e desenhos para explicar melhor o que diz, o senhor Valéry busca formas de concretização e ordenação da sua realidade, como se objetos, desenhos e formas geométricas fossem âncoras a firmar pensamentos à deriva.

É como se ele tentasse igualmente compensar graficamente sua carência afetiva, ao ocupar-se com tarefas organizatórias, sempre com o objetivo implícito e possivelmente inconsciente, de pôr ordem em seu mundo psíquico caótico, mais do que propriamente de prover soluções efetivas para os seus problemas.

Há também, da parte deste senhor, sendo ele próprio um indivíduo excêntrico, uma busca de simetria e centramento. Segundo Linda Hutcheon,

$\underline{O}$ centro pode não permanecer, mas ainda é uma atraente ficção de ordem e unidade que a arte e a teoria pós-modernas continuam a explorar e subverter. Essa ficção assume muitas formas nas instituições de cultura e, em muitas delas, suas limitações estão passando a ser o foco de atenção. [...] $\underline{\mathrm{O} \text { ex- }}$ cêntrico, o off-centro: inevitavelmente identificado com o centro ao qual aspira, mas que lhe é negado. Esse é o paradoxo do pós-moderno, e muitas vezes suas imagens são tão divergentes quanto $o$ pode sugerir essa linguagem de 
descentralização: a aberração é um exemplo comum [...] (HUTCHEON, 1988, p. 88-89, grifo da autora, sublinhado nosso).

Corroborando as afirmações de Hutcheon sobre a multiplicidade e a heterogeneidade, é possível observar no senhor Valéry tal tendência, marcada por seus constructos imaginários. Sua fixação em usar a mão esquerda para os objetos à esquerda e a direita para os que estão do lado direito, não elimina a preocupação de busca pelo centro:

Aos objectos muito pesados coloco-os exactamente com o seu centro na linha. E desenhou. Assim - explicava o senhor Valéry - posso carregá-los utilizando a mão esquerda e a mão direita, desde que tenha o cuidado de os transportar com o seu centro exactamente sobre a linha divisória. Para os objectos leves [...] - não necessito de tantas preocupações: mudo-lhes a posição apenas com uma das mãos. A mão certa, claro (TAVARES, 2004a, p. 16-17, sublinhado nosso).

Uma parte dos meandros peculiares da psique e do raciocínio deste senhor são revelados por meio de um diálogo com um amigo, quando Valéry Ihe explica acerca do funcionamento das suas escolhas de lateralidade:

Mas como manter esse rigor em todas as situacões? perguntou-lhe o mesmo amigo: Quando o senhor Valéry está de costas, por exemplo, como sabe qual a parte direita $e$ esquerda da casa? O senhor Valéry mostrou-se quase ofendido com a questão, pois não gostava de ser posto em causa, e respondeu, bruscamente: Eu nunca viro as costas às coisas. (Isto era que o senhor Valéry dizia, mas na verdade, para nunca se enganar, havia pintado todo o lado direito da casa, incluindo os seus objectos, de vermelho, e todo o lado esquerdo de azul. [...]. Não tinha sido um acto estético, como ele dizia. Era bem mais do que isso) (Idem, p. 17-18, sublinhado nosso). 
O senhor Juarroz, por seu turno, é um formulador de conceitos, em oposição ao senhor Valéry, que é, antes de tudo, um executor, pronto a resolver problemas na prática. O senhor Juarroz tem a mente de um teórico, que funciona mais ao nível de conjeturas e pensamentos. Suas definições, explicações e hipóteses são eminentemente abstratas, mentalmente desenvolvidas, e com pouca ou nenhuma conexão com a vida ou os eventos concretos:

O senhor Juarroz estava a pensar que os dentes, a língua, e a garganta funcionavam, em conjunto, como escultores do ar, transformando este em palavras. Dizer a palavra mais simples (como cão ou mesa) pressupõe um trabalho manual pormenorizado executado pelos órgãos e tubos por onde o ar passa. Se não fôssemos escultores verbais com a boca só faríamos ruído, como a água a ferver [...] (TAVARES, 2007, p. 39, grifo do autor, sublinhado nosso).

Enquanto desenvolve tais ideias, o senhor Juarroz é surpreendido pela realidade:

De repente, o senhor Juarroz parou de pensar e prestou atenção ao seu ouvido. Realmente, da cozinha vinha um som estranho, semelhante a água a ferver. $O$ senhor Juarroz levantou-se então rapidamente e correu para a cozinha. Sim, $\underline{a}$ áqua já se evaporara de novo da cafeteira. Em dez minutos era a terceira vez que se esquecia da áqua ao lume (Idem, p. 39, sublinhado nosso).

Trata-se de alguém que evita os contatos externos diretos, os quais chegam mesmo a incomodá-lo fisicamente. Seu refúgio é o mundo interior: "Como a realidade era para o senhor Juarroz uma matéria aborrecida ele só deixava de pensar quando era mesmo imprescindível" (Ibid., p. 9).

A citação acima revela a inadequação desse senhor em relação à realidade tal qual a conhecemos, característica que se estende de formas diversas aos demais senhores. Na verdade, todos sentem o incômodo causado pelo mundo circundante, com sua lógica formal abrangente e padronizada, que 
insiste em obrigá-los a fazer parte de um mainstream racional ao qual não pertencem. O mundo de que o senhor Juarroz declara gostar é o seu mundo particular, isolado pela venda nos olhos, pelo algodão nos ouvidos, pela mola que Ihe fecha o nariz, e com as mãos suspensas no ar para que não toquem em nada.

Suas escolhas e métodos de afastamento da realidade constituem uma tentativa de encontrar conforto e ser o que é, já que para todos os senhores a relação Eu-Outro é algo de realização demasiadamente complexa e penosa.

Pesa também aí o fato da não identificação com a alteridade, na qual os senhores não encontram pontos de semelhança ou contato. Na verdade, há, da parte de todos eles, uma busca pelo Outro idealizado e não pela alteridade real. Seu mundo visto de fora se nos afigura dual. Contudo, isso pode constituir uma impressão enganosa, já que o universo aparentemente ambíguo dos senhores pode esconder multiplicidades. Assim,

O conceito modernista de uma não-identidade única e alienada é desafiado pelo questionamento pós-moderno dos binários que ocultam hierarquias (eu/outro). Quando exige que a teoria atual possua uma "percepção das diferenças entre situações" em sua "consciência crítica" sobre sua posição no mundo, Edward Said (1983, p. 242) está ultrapassando a antiga definição de Foucault (1970) sobre a modernidade unicamente em termos de não-identidade. A diferença sugere a multiplicidade, a heterogeneidade e a pluralidade, e não a oposição e a exclusão binárias (HUTCHEON, 1988, p. 88-89, grifo da autora, sublinhado nosso).

O senhor Juarroz apresenta, pois, comportamentos paradoxais. Em alguns momentos, ele se afasta de qualquer contato com o mundo exterior. Em outros, o que este senhor deseja é justamente o oposto do que usualmente faz: o abominado passa a ser o objeto do desejo. Desse modo, "Como era deselegante não ver nada com tantas coisas para serem vistas, o senhor Juarroz ficava em casa, à janela, a ver as coisas do mundo. Como era possível 
dentro de casa ouvir o silêncio, o senhor Juarroz abria a janela para entrarem ruídos, pois, no fundo, detestava o silêncio" (TAVARES, 2007a, p. 29).

Observa-se aí que, ao modificar sua atitude mental com referência ao mundo exterior, sua nova aproximação é relativa, já que não tenta sair de casa e se aproximar de fato do Outro ou da materialidade da vida lá fora. Ele apenas abre a janela para que a exterioridade, apenas em pequena e controlada medida, chegue até ele.

Sendo um formulador de ideias e hipóteses, seus pensamentos vagueiam em muitas direções. Assim, em "Os trabalhos manuais", ele divaga:

Para um analfabeto escrever é um trabalho manual, pensava o senhor Juarroz. É um trabalho físico semelhante a copiar o molde de um vaso; e um analfabeto tentando ler é como um míope que, afastado cem metros, tenta observar os gestos de

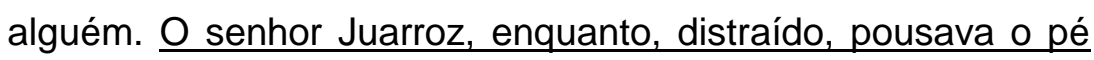
sobre excrementos recentes de um volumoso animal, convencia-se, $[\ldots .$.$] de que tudo na existência, mas mesmo tudo,$ não passava de trabalhos manuais (Idem, p. 55, sublinhado nosso).

As desavenças que o senhor Juarroz tem com a esposa em relação a manter uma "gaveta para guardar o vazio" (p. 13), revelam um comportamento que se contrapõe à ideia corrente na sociedade contemporânea, que é a de que a utilidade de um objeto deve prevalecer em relação a outros atributos.

Tal é o pensamento utilitário da senhora Juarroz. Além desse aspecto, há aí uma referência à questão do vazio existencial, da aparente falta de serventia do que não é eminentemente funcional, capaz de servir a um propósito específico, além do fato de que a aceitação do vazio, do silêncio, da suposta falta de algo, que preencha tempo e espaço, torna-se cada vez mais intolerável para indivíduos da contemporaneidade, que desejam completar suas vidas com ruídos, objetos, tarefas, pessoas, durante todo o tempo.

Se por um lado, a senhora Juarroz exerce uma força no sentido de ocupar a gaveta e torná-la útil, evitando que se transforme em "uma péssima utilização do metro quadrado" (p. 13), o senhor Juarroz, por seu turno, age no 
sentido oposto, contrariando as expectativas da "normalidade", ao tentar se sentir com algum poder sobre as coisas, recuperando, segundo Bauman, a sensação reconfortante de que tem algo, de fato, "sob controle".

Para o autor,

Não é este, para estar seguro, um controle no sentido agora antiquado, fora de moda, e heróico, de quem grava a sua forma no mundo, refazendo o mundo em sua própria imagem, ou querendo-o e conservando-o como tal. Este não é senão o que se pode chamar o 'controle situacional' - a aptidão para escolher onde e com que partes do mundo 'interfacear', e quando desligar a conexão (BAUMAN, 1998, p. 115, grifo do autor, sublinhado nosso).

Se visto de fora, percebe-se que o senhor Juarroz apresenta certos comportamentos devido à rejeição de sua parte em relação ao entorno:

Eis algumas situações em que era obrigado a deixar de pensar:

- quando falavam com ele muito alto;

- quando o insultavam;

- quando o empurravam;

- quando tinha de utilizar qualquer objeto útil à sua volta

(TAVARES, 2007a, p. 9).

As situações que interrompem seus pensamentos são, pois, todas em que o mundo exterior tenta estabelecer contato com ele, seja falando mais alto, por pensarem que ele não ouve quando lhe dirigem a palavra; seja por meio de xingamentos, diante da aparente indiferença da personagem; seja quando o empurram para forçá-lo a ouvir, responder ou reagir; ou sempre que o senhor Juarroz tem de realizar algo prático, utilizando um objeto qualquer.

Mesmo quando forçado por gritos, desaforos ou empurrões, há resistência por parte da personagem em sair do seu mundo privado, fato que provoca impressões equivocadas, pela suposição de que ele:

- era surdo (porque não ouvia quando falavam com ele muito alto); 
- era covarde (porque o insultavam e ele não reagia); - era muito covarde (porque o empurravam e ele não reagia);

- era desastrado (porque pegava mal nas coisas, deixando-as cair ao chão). No entanto, ele não era nem surdo, nem covarde, nem desastrado. Simplesmente, para o senhor Juarroz, a realidade era uma matéria que aborrecia (Idem, p. 9, sublinhado nosso).

Pode-se falar, no caso do senhor Juarroz, de uma espécie de cronotopo da vida interior, que é o tempo/espaço em que vive a personagem, como se estivesse permanentemente fechada em um casulo.

Como sempre paradoxal, o senhor Juarroz é de opinião que o toque nas coisas revela, além de falta de gentileza, também "[...] um fracasso, primeiro do pensamento, depois da audição e do olfato e, por último, da visão. Só toco nas coisas porque fracassei - disse alto o senhor Juarroz no momento em que dava um vigoroso aperto de mão a um vizinho" (Ibid., p. 47).

Teorizar é, para este senhor, uma afirmação de liberdade e autonomia, ainda que signifique, em contrapartida, uma escravização a procedimentos rígidos. É no espaço dessa contradição, que vivem, não apenas o senhor Juarroz, mas também os demais senhores e o homem da contemporaneidade.

Para Terry Eagleton,

Se, [...], o sujeito pós-moderno é determinado, ele é também independente, contingente, aleatório, e por isso um tipo de versão parodiada da liberdade negativa do eu liberal. Já vimos antes como acontece de esse conceito de heterogeneidade associar essas idéias antitéticas: se o sujeito se mostra escorregadio, é porque atua como o ponto de atrito entre forças culturais incompatíveis. Existe muito do desejo nietzschiano de poder nessa visão; [...]. Onde mais você pode sentir-se ao mesmo tempo moldado por forças implacavelmente determinantes e perdido de modo alarmante? Esse sujeito é em certos aspectos tanto uma criatura do mercado quanto o foi o sujeito muito diferente do liberalismo clássico, que também, 
aliás, tinha dificuldade de conciliar sua liberdade com seu determinismo (EAGLETON, 1998, p. 90-91, sublinhado nosso).

O comportamento dos senhores reflete a proposta de Eagleton, que consiste na assertiva de que o sujeito da pós-modernidade vive no meio da tensão entre duas forças. Ora ele se sente como o senhor da livre escolha, ora é compelido a fazer determinadas opções. No entanto, no caso dos senhores, e possivelmente também no caso do homem pós-moderno, o que aparenta ser uma escolha deliberada, não o é. Há razões subliminares que já, de antemão, o "obrigam" a optar por isto ou aquilo, e que por virem acompanhadas de um determinismo de base, subrreptício ou disfarçado, dão a ele a impressão de que as escolhas são suas, quando, na verdade, não o são.

O caso do senhor Valéry ilustra bem essa visão, já que, devido a compulsões e idiossincrasias, ele opta por tocar as coisas à direita com a mão direita e vice-versa, a partir de uma "livre vontade". Do mesmo modo, também o homem da contemporaneidade, impulsionado por razões de mercado, é levado a crer que "escolhe", quando, de fato, não o faz. A ideia de liberdade também é "vendida" como um produto e assimilada de modo imperceptível, conferindo a esse homem e a todos os "compradores", a falsa ideia de que são indivíduos autônomos.

Corroborando a ideia acima, Giddens fala do período da alta modernidade, em que se situa o auge da empresa capitalista, a qual funciona sobre o mercado em duas vertentes: a de moldar o consumo e a de monopolizar as condições de produção. Segundo ele,

Desde o comecco, os mercados promovem o individualismo na medida em que sublinham direitos e responsabilidades individuais, mas no primeiro momento esse fenômeno diz principalmente respeito à liberdade de contrato e à mobilidade intrínseca ao emprego capitalista. Mais tarde, porém, o individualismo se estende para a esfera do consumo, a identificação das preferências individuais tornando-se fundamental para a continuidade do sistema (GIDDENS, 2002, p. 183, sublinhado nosso). 
Nesse sentido, usufruindo o que aparenta ser a "liberdade" de consumir, o indivíduo sente que o preenchimento instável e temporário que os bens de consumo representam como simulacros de satisfação, acabam por gerar um processo infindável de busca por prazeres efêmeros, o que significa, em última análise, crescimento econômico promovido a um alto custo emocional.

Ainda segundo Giddens,

[...] a mercantilização influencia o projeto do eu e o estabelecimento de estilos de vida. [...]. A própria corrupção da noção de "estilo de vida", reflexivamente trazida para a esfera da propaganda, resume esses processos. Os publicitários se orientam por classificações sociológicas de categorias de consumidores e ao mesmo tempo estimulam "pacotes" específicos de consumo. Em maior ou menor grau, o projeto do eu vai sendo traduzido como a posse de bens desejados e a perseguição de estilos de vida artificialmente criados (Idem, p. 182-183, grifo do autor, sublinhado nosso).

De acordo com tal ideia, os objetivos do mercado só podem ser atingidos mediante o papel desempenhado pela publicidade. A "customização" de bens dá aos indivíduos a sensação de que "merecem" o que adquirem a um alto preço, já que os produtos foram projetados especialmente para preencher "as suas necessidades vitais". Ao comprar uma casa em um condomínio, um carro, ou um apartamento, o indivíduo entra na posse de algo mais valioso que um bem material, ou seja, ele está adquirindo um "estilo de vida".

Quanto ao senhor Valéry, ele tem, mesmo que vaga, uma noção de incompletude, ainda que não tenha crises de identidade: "[...] o senhor Valéry não tinha crises graves de identidade, tinha apenas crises de fígado no Inverno" (TAVARES, 2004a, p. 58). O fato de não se sentir completo o impele a levar para casa tudo em que toca, como mais uma obsessão: "Como não me sinto completo comigo apenas, penso que tudo o que não sou eu me poderá completar, e portanto quero-o para mim, e roubo-o ao mundo" (Idem, p. 77).

O furto não tem aí o sentido de delito, mas consiste em um indicativo do deslocamento e da inadequação desse senhor em relação ao mundo que o 
rodeia, bem como da enorme distância que o separa do Outro, fazendo-o agir de modo a suprir seu vazio existencial com objetos "roubados".

Ao se sentir impotente e solitário e, por conseguinte, incapaz de ver sua incompletude preenchida pela alteridade, ele se vale da apropriação compulsiva de bens, na vã tentativa de obter satisfação emocional, tal como o homem da contemporaneidade, que se transforma muitas vezes em um consumidor compulsivo, para quem a aquisição e a posse substituem, em certa medida, necessidades afetivas e emocionais não satisfeitas.

Se por um lado, o senhor Valéry estabelece como paradigma o Outro, ao tentar parecer alto, e, portanto, não inferior aos demais, por outro, ele tem grande dificuldade em criar vínculos afetivos, tornando-se, assim, presa constante de dilemas duais: na falta de uma lógica formal, ele cria sua própria lógica e seus rituais de segurança, na forma de uma suprarrealidade, como ao explicar as razões pelas quais se veste sempre de preto. Assim,

[...] Ao verem-me de preto julgam-me de luto e, por compaixão, não me enviam mais sofrimento. E dizia ainda: Não se pode sofrer o dobro de muito. É essa, aliás, a única razão porque consigo ser feliz, em certos dias: o meu fato de luto engana-os. E é sempre boa a sensação de enganar os mais fortes acrescentava, orgulhoso, o senhor Valéry [...] (Ibid., p. 55, sublinhado nosso).

O fato de ser metódico-compulsivo contribui para o seu isolamento em um universo à parte. Vivendo o solipsismo, ele não aceita a relatividade, a variação ou a alteridade, indo, por esta razão, aos extremos, sem nuances ou colorações intermediárias: as coisas devem estar à direita ou à esquerda, de um modo ou de outro, sem meios termos.

Ao mesmo tempo em que trabalha com a imaginação ao planejar, por exemplo, sua casa de férias, ele necessita materializar o que imagina a partir de imagens, no caso, as portas, objetos que carregam a simbologia da liberdade, do escape, metáfora do livre trânsito e da comunicação direta entre a dimensão interna e externa de si mesmo e das coisas, em oposição ao engessamento crônico em que vive. 
Nessa acepção, os desenhos consistem na única concretização possível, já que ele não consegue tornar real o que na verdade desejaria possuir. Por não ter tudo e para não sofrer, é melhor ter alguma coisa. Se não tem a casa, pelo menos as portas são possíveis em seus desenhos expedientes de tradução das suas ideias e representações simbólicas do seu esforço para convencer o Outro da sua verdade peculiar. Assim,

O senhor Valéry tinha uma casa sem volume onde passava férias. A porta e uma fachada eram as únicas coisas que existiam. Nos 2 sentidos se pode entrar e sair - dizia o senhor Valéry, todo contente. [...]. Melhor só mesmo uma casa com quatro portas, em quadrado, sem nenhuma parede. $\mathrm{O}$ centro a restar como o único sítio onde se pode estar sentado. O senhor Valéry fez um desenho ${ }^{31}$ (Ibid., p. 27-28, sublinhado nosso).

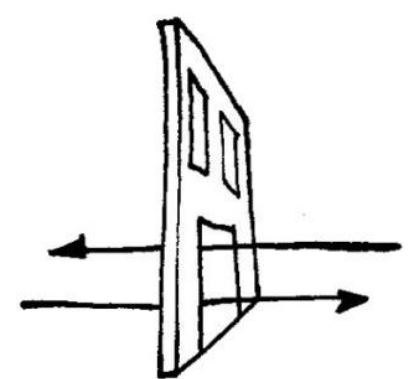

Tal como faz com seu bicho de estimação, seu ideal de proteção é estar preso em uma "caixa". Ele explica as vantagens da sua casa idealizada:

Chamou-Ihe: a casa das quatro portas juntas. Entra-se por qualquer lado e é sempre igual. É esta a casa de férias que eu quero - dizia o senhor Valéry. Evitarei perder-me em compartimentos - dizia. Só existirão portas. É que só consigo repousar se não tiver que decidir nada, e para que isso aconteça é indispensável não existirem opções (Ibid., p. 28, sublinhado nosso).

${ }^{31}$ Desenhos desta e da página seguinte de Rachel Caiano. In: TAVARES, Gonçalo M. 0 senhor Valéry. Porto Alegre: Escritos, 2004a, p. 27-28. 


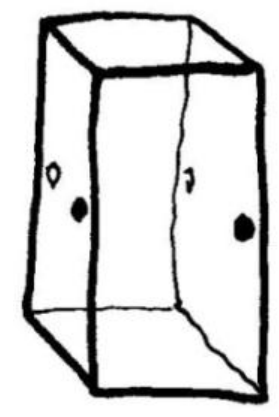

No fundo, este senhor se empenha em dar uma explicação aparentemente lógica ao que não é lógico per se, devido ao fato de não aceitar o erro, a fragilidade, a relatividade do mundo e das coisas, o lado humano que sofre, erra, teme, perde entes queridos. As tentativas organizatórias do seu mundo particular buscam a previsibilidade que só um ordenamento, ainda que inusitado, permite, como uma espécie de antídoto a que ele pode recorrer para não se sentir desprotegido e só.

Não por outra razão, "O senhor Valéry dormia sempre de pé para não adormecer" (Ibid., p. 29). Dormir significa para ele a perda do controle e a possibilidade de colocar-se ainda mais exposto aos perigos de estar vivo. De fato, ele sente em todos os momentos algum tipo de temor intrínseco, difuso e abrangente: medo de dormir; (p. 29); medo de perder o seu animal de estimação (p. 11); medo de perder amigos (p. 10); medo de perder-se dentro de casa (p. 28); medo do ridículo (p. 13).

Apesar de tudo, o senhor Valéry também reserva um espaço para os desejos, em menor número do que os medos. Ele revela, em certos momentos, seu anseio por companhia e convivência, evidenciado em sua vontade de estabelecer relacionamentos, transformar-se, e ser feliz: "Na verdade, as ruas agarram-se aos meus sapatos porque eu não sou feliz - disse o senhor Valéry, melancólico. [...]. No fundo - [...], devemos juntar-nos, sim, àquilo precisamente que não gostamos de ser, para assim nos conseguirmos transformar no que pretendemos" (Ibid., p. 78-79, sublinhado nosso).

Todas as explicações "lógicas" deste senhor são, por via de regra, a expressão da lógica da intransigência, sendo ele próprio o inverso, ou seja, a paródia invertida do Valéry poeta, que lida com a arte, a ambivalência, a 
irrealidade, o intangível, coisas com as quais o senhor Valéry se sente impotente para manejar.

$\mathrm{Na}$ falta da alteridade, ele espera encontrar, em algum ponto do futuro, ao menos o Outro de si mesmo, de modo a reunir em um todo harmônico os pedaços do seu Eu fragmentado. Dessa forma, ele diz:

O passado tem um senhor Valéry, o presente sou eu, e o futuro terá um outro senhor Valéry. Pelos meus cálculos, sou três pessoas. No mínimo. No entanto - dizia ainda o senhor Valéry - 3 pessoas podem ser uma no caso de se conhecerem muito bem. [...]. (Conhecer 3 pessoas e ser com elas uma única terá murmurado ainda, lá ao fundo, o senhor Valéry) (Ibid., p. 57-58, sublinhado nosso).

Em um insight final, o senhor Valéry tem um relance de compreensão de tudo o que o incomoda e o compele a ser o que é. Advém-Ihe, de repente, a constatação inexorável da necessidade de não apenas aproximar-se do Outro, mas de conhecer-se. Nesse momento, tal percepção lúcida o faz desenhar aquilo que simbolicamente representa o seu Eu fragmentado, o qual explode numa profusão de estilhaços. "O senhor Valéry depois não disse mais nada já estava cansado e era tarde - porém o último desenho que fez foi o de um quadrado dividido em muitos bocadinhos" ${ }^{\text {"22 }}$ (Ibid., p. 80, sublinhado nosso).

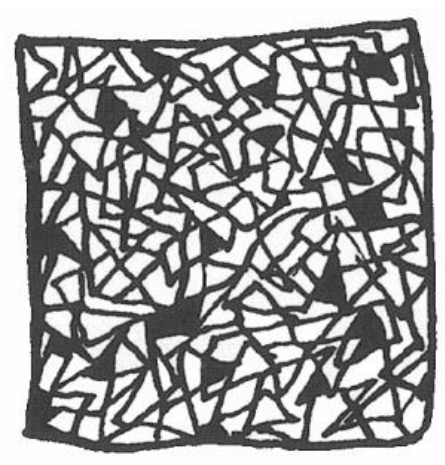

Já no caso do senhor Juarroz, há outro fator importante a determinar as aparentes mudanças aleatórias de atitude. Como um ser em crise, ele tenta manter controle sobre as coisas imediatas, as poucas sobre as quais tem

32 Desenho de Rachel Caiano. In: TAVARES, Gonçalo M. O senhor Valéry. Porto Alegre: Escritos, 2004a, p. 80. 
algum poder de decisão. Destarte, abrir ou fechar a janela, ter ou não contato com o mundo exterior em seus aspectos periféricos - como é o caso do uso dos sentidos - oferece a ele uma área de segurança psicológica desejável.

Outra característica marcante da pós-modernidade, e que é, em parte e de modos diferenciados, comum a todos senhores, e à qual Giddens faz menção, é a da expansão dos sistemas abstratos, nos quais se incluem os avanços tecnológicos e os poderes do Estado sobre as vidas dos indivíduos, que têm tirado progressivamente do sujeito o poder de decisão sobre a sua vida. Não seguir as tendências do mercado equivale a estar à margem, desatualizado, desprovido de pertença a um grupo social ou a uma causa, esvaziado da própria identidade. Para o autor,

A noção de estilo de vida ${ }^{33}$ soa um tanto trivial porque é muitas vezes pensada apenas em termos de um consumismo superficial - estilos de vida como os sugeridos pelas imagens das revistas ilustradas e da publicidade. Mas há algo mais fundamental em andamento do que sugere essa concepção: nas condições da alta modernidade, não só seguimos estilos de vida, mas num sentido somos obrigados a fazê-lo - não temos escolha senão escolher. Um estilo de vida pode ser definido como um conjunto mais ou menos integrado de práticas que um indivíduo abraça, não só porque essas práticas preenchem necessidades utilitárias, mas porque dão forma material a uma narrativa particular da autoidentidade (GIDDENS, 2002, p. 79, sublinhado nosso).

Do mesmo modo, os senhores, cada um com características próprias, também têm um estilo, mesmo que não tenha sido voluntariamente escolhido, mas que os define do ponto de vista identitário, estilo esse que lhes permite, em certa medida, posicionar-se contra as exigências do mercado, na tentativa de escapar de pressões impostas de fora.

\footnotetext{
${ }^{33}$ O termo "estilo de vida" é um exemplo interessante de reflexividade. O colunista do New York Times, William Safire sugeriu que ele deriva dos escritos de Alfred Adler, de onde foi tomado pelos radicais dos anos 1960 e, mais ou menos ao mesmo tempo, pelos redatores de publicidade. Segundo Dennis Wrong, entretanto, a principal influência foi realmente Max Weber: "estilo de vida", tal como associado aos estamentos no uso weberiano, se tornou termo da linguagem cotidiana. (Nota do autor, p. 79.)
} 
Uma das consequências de tais imposições externas é a perda da privacidade que atinge o homem da contemporaneidade, cuja vida se torna pública a partir do uso maciço dos meios digitais, reduzindo os indivíduos a números, paradoxalmente protegidos por outros números.

Vale ressaltar que, tanto a enciclopédia e o absinto para o senhor Henri, como a biblioteca para o senhor Juarroz, os esquemas e desenhos para 0 senhor Valéry, as histórias para o senhor Brecht, o balão para o senhor Calvino, as crônicas para o senhor Kraus, bem como a casa para o senhor Walser, e a entrevista para o senhor Breton, representam, em última instância, paradigmas de organização e de defesa, dos quais eles se apropriam em uma tentativa de garantir um espaço próprio, além de assegurar certo ordenamento para seus mundos virados pelo avesso.

É possível depreender que os senhores, cada qual a seu modo, propõem maneiras diferentes e inusitadas de encarar o mundo e as coisas. Vivendo a realidade da contemporaneidade, em que os métodos, as padronizações e os controles obrigam a que os indivíduos sigam modos de pensar coletivamente massificadores, não deixa de ser oportuno seguir por vias alternativas, à moda do senhor Calvino, caminhos que podem levar a agradáveis surpresas.

A busca de respostas por parte dos senhores pode ser resumida, no caso do senhor Juarroz, pela narrativa "Como encontrar a luz?", em que se revela o seu desejo de encontrar um ponto de claridade na escuridão, representação esperançosa de uma "utopia possível":

O senhor Juarroz acreditava que era possível encontrar um ponto de intensa claridade no meio da noite mais escura. Como estava cansado, o senhor Juarroz pediu à sua esposa que fizesse o seguinte desenho. 0 senhor Juarroz preparou-se depois para ir procurar esse tal ponto luminoso no meio da noite mais escura. E se tropeças? - perguntou a esposa. Levo a lanterna - respondeu, com simplicidade, o senhor Juarroz (TAVARES, 2007a, p. 53, sublinhado nosso). 
Então, a pedido do marido, a esposa do senhor Juarroz faz o desenho ${ }^{34}$. Tal como o senhor Valéry sonha em juntar os pedaços fragmentados do seu Eu, também o senhor Juarroz sai no meio da noite escura, tentando achar o seu ponto de luz, metáfora do autoconhecimento, capaz de clarear os pontos escuros do seu psiquismo:

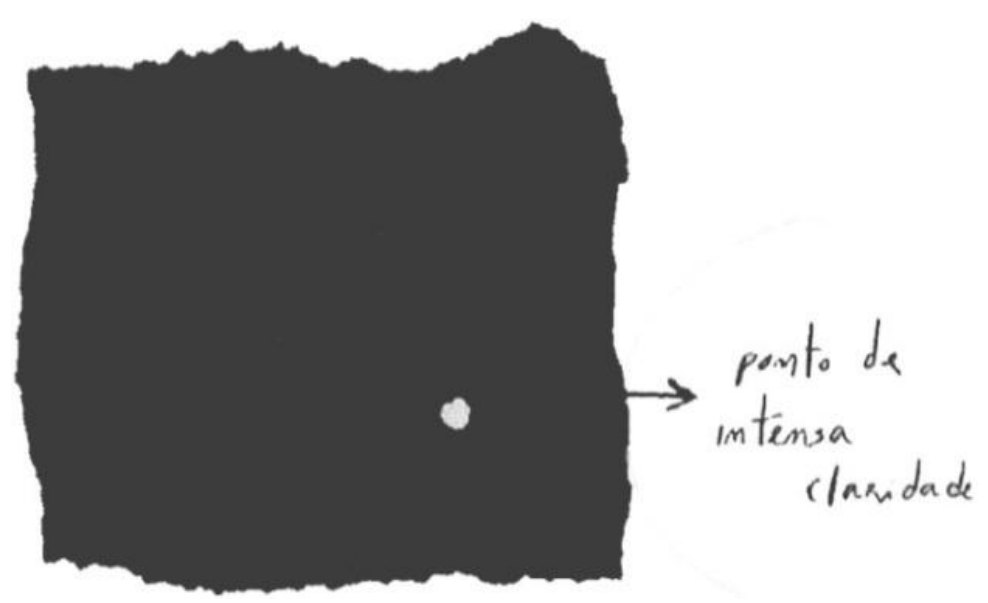

Incomodado como sempre pela realidade, e perdido em um mundo hostil, ciente, ainda, de que até as forças sobrenaturais oferecem hoje pouco ou nenhum alento, "O senhor Juarroz pensou em um Deus que, em vez de nunca aparecer, aparecesse, pelo contrário, todos os dias, a toda a hora, a tocar à campainha. Depois de muito meditar sobre esta hipótese, o senhor Juarroz decidiu desligar o quadro da eletricidade" (Idem, p. 61).

E recolheu-se, novamente, para dentro de si: "E com a venda nos olhos, o algodão nos ouvidos, e a mola no nariz, o senhor Juarroz, tendo o cuidado de manter as mãos no ar para não tocar em nada, tinha então momentos de pura felicidade de pensamento. Como gosto do mundo, murmurava" (Ibid., p. 63).

Tal distanciamento consiste, destarte, em encontrar meios de defesa e proteção contra um ambiente externo, que se revela agressivo não apenas para os senhores, mas para o homem da contemporaneidade de modo geral.

\footnotetext{
${ }^{34}$ Desenho de Rachel Caiano. In: TAVARES, Gonçalo M. O senhor Juarroz. Rio de Janeiro: Casa da Palavra, 2007a, p. 53.
} 


\section{5 Eu e Vossas Excelências: o senhor Henri}

"[...] o meu pensamento localiza-se no espaço que existe, ainda vazio, entre as células e o absinto. É nesse pequeno espaço, é nesse pequeno resto, que eu consigo pensar" (O senhor Henri) ${ }^{35}$.

Vizinho do senhor Brecht, o senhor Henri, tal como os outros senhores, apresenta as suas particularidades comportamentais bem como a sua peculiar visão de mundo. Assim, ele é capaz de falar com precisão sobre datas e invenções, úteis e inúteis, sobre descobertas científicas, conceitos filosóficos, hipóteses e predições, tudo com aparente conhecimento de sábio, independentemente de suas afirmações serem ou não verdadeiras.

Viciado em absinto, suas ideias são em grande parte influenciadas pela bebida, especialmente quando filosofa: "[...] já percebo por que razão se começa a pensar. ... é por causa do cansaço. ... se todos os homens tivessem uma boa condição física não haveria um único filósofo" (TAVARES, 2004b, p. $15)$.

Para este senhor, o absinto é a suma representação da evolução humana em todos os sentidos, precedendo temporalmente todas as outras invenções: "[...] ... O absinto foi inventado antes da inteligência, aqui está um dos raros factos históricos incontornáveis" (Idem, p. 55-56).

A razão pela qual o senhor Henri consome absinto especificamente, e não outra bebida, pode estar associada ao fato de que especificamente o absinto tem carregado, ao longo de décadas, um estigma de transgressão, tendo sido proibido o seu consumo na Europa e, logo depois, nos Estados Unidos, no início do século XX, tornando-se, portanto, uma droga ilícita e cobiçada à época, especialmente pelos artistas. Além disso, a bebida esteve associada, por longo tempo, e com respaldo científico, a crenças que the

${ }^{35}$ TAVARES, 2004b, p. 19. 
atribuíam o poder de causar vários problemas sociais e de saúde, como epilepsia, suicídio e loucura, além do aumento da criminalidade ${ }^{36}$.

Em O senhor Henri (TAVARES, 2004b), é possível observar, mais do que nos outros livros que compõem a série Os Senhores, uma forte influência do cronotopo rabelaisiano e do processo de carnavalização, conforme descrito por Mikhail Bakhtin (2008, p. 239).

Do mesmo modo que no cronotopo original de Rabelais, há a libertação do mundo oficial, a quebra dos níveis hierárquicos, a afirmação do riso sobre as falsas convenções, também o senhor Henri representa um rompimento em relação ao sistema e aos códigos sociais da contemporaneidade, sistema esse que, paradoxalmente, confere a impressão de liberdade e, ao mesmo tempo, constrange e controla a vida dos indivíduos.

Pode-se afirmar que a liberdade de ações e movimentos do senhor Henri é mais ampla também do que a dos demais senhores, transitando ele, livremente, da rua para o cronotopo do bar/sala de visitas, seu ambiente preferido, sem sentir vergonha ou angústia por ser o que é: verborrágico, beberrão, liberado de qualquer amarra social. Surge aqui, entre todos os senhores, aquele que utiliza seu espaço sem reservas ou contingências, que se dá a liberdade de dizer grosserias e de elogiar, que vive a vida como quem sorve o último gole.

Vale ressaltar que o cronotopo rabelaisiano compreende cenas e figuras eminentemente físicas e concretas, com forte apelo visual e dos sentidos em geral. Trata-se de um processo de renovação que põe de parte antigas crenças e, apropriando-se de uma nova ideologia, permite que o físico e o material encontrem lugar em um mundo antes apenas voltado para o além-vida e o espiritual. Segundo Mikhail Bakhtin,

Todos os episódios e figuras estudados até aqui, todas as cenas de batalhas, brigas, golpes, ridicularizações, destronamentos, tanto de homens [...] como de coisas [...], são tratados e estilizados no espírito da festa popular e do carnaval. Eles são, portanto, ambivalentes: a destruição e o

\footnotetext{
${ }^{36}$ NTP: Summary of data for chemical selection Alpha-Thujone 546-80-5, 2005. The National Toxicology Program. (Ver Referências.)
} 
destronamento estão associados ao renascimento e à renovação, a morte do antigo está ligada ao nascimento do novo; todas as imagens são concentradas sobre a unidade contraditória do mundo que agoniza e renasce [...]. (Idem, p. 189, sublinhado nosso).

A personagem, ao falar sobre fatos históricos e científicos do passado, promove, em certa medida, o rebaixamento do que é acadêmico e formal. Ao praticar uma falsa erudição, o senhor Henri destrona o academicismo pomposo e falso, feito para a exibição do que é eminentemente culto, mas com poucos efeitos, em muitos casos, para a sociedade e para a própria academia.

Os dados históricos e científicos que ele apresenta são rasurados, e a sua fonte é tão-somente a enciclopédia. De certo modo, ao criticar o que é acadêmico, ele também critica o elitismo, a educação formal como privilégio de poucos e como meio de segregar os indivíduos. Ao verbalizar a sua pseudoerudição no democrático cronotopo do bar/sala de visitas, ele aproxima o que na realidade, não está próximo: o conhecimento formal organizado, representativo da esfera apolínea; e o dionisíaco, figurativizado na bebida, na descompostura, no discurso e no divertimento livres, próprios do que é de Baco, segundo o conceito de Nietzsche, elaborado por Marcio Benchimol (2002), e mencionado anteriormente neste trabalho.

Em sua obra, $\mathbf{O}$ nascimento da tragédia, publicada em 1871, Nietzsche afirma que:

A tragédia grega, [...], depois de ter atingido sua perfeição pela reconciliação da "embriaguez e da forma", de Dioníso e Apolo, começou a declinar quando, aos poucos, foi invadida pelo racionalismo, sob a influência "decadente" de Sócrates. Assim, [...] Apolo é o deus da clareza, da harmonia e da ordem; Dioníso, o deus da exuberância, da desordem e da música. [...] o apolíneo e o dionisíaco, complementares entre si, foram separados pela civilização (Os pensadores, volume Nietzsche, capítulo "O filósofo e o músico", 1999, p. 6, grifo do autor, sublinhado nosso). 
Ao alterar os dados da enciclopédia à sua conveniência, o senhor Henri põe em cheque, de certa forma, o conhecimento formal, especialmente quando este se aparta de toda e qualquer função social. Ao proferir seus discursos "pedagógicos" no cronotopo do bar/sala de visitas, ele estende democraticamente aos que ali estão o seu próprio saber, ainda que corrompido.

O contrário também ocorre. Ao chamar os frequentadores e balconistas por pronomes de tratamento formais e solenes, ele dispensa aos embriagados fregueses e aos simples balconistas, o trato e a consideração dispensados a figuras socialmente proeminentes, em uma inversão própria do cronotopo de Rabelais, segundo a concepção de Bakhtin (2008).

O uso dos pronomes de tratamento rebuscados não impede, contudo, que 0 senhor Henri ofenda àqueles que foram cerimoniosamente tratados pouco antes. Assim se consuma, pois, a improvável combinação: “[...] ... vossa excelência fique a saber que é um hipócrita, e a partir de hoje não me dirija a palavra" (TAVARES, 2004b, p. 92).

Da mesma forma, ao se apropriar o senhor Henri de certo tipo de conhecimento, ainda que rasurado e restrito, valoriza, segundo seus parâmetros, o conhecimento formal: "[...] ... é impossível o homem viver sem informação. ... a informação - disse o senhor Henri, já com a língua meio enrolada - a informação é o outro lado do absinto" (Idem, p. 34) .

Em medidas diferentes, todos os senhores vivem em uma espécie de cronotopo rabelaisiano modificado, em que nada é o que parece ser, ou ainda, uma coisa pode ser isto ou aquilo, e também isto e aquilo simultaneamente, como é o caso da simbologia da morte, a qual, na obra de Rabelais está associada à vida, ou seja, o que morre fecunda a nova vida nascente, segundo Bakhtin:

A tarefa essencial de Rabelais consistia em destruir o quadro oficial da época e dos seus acontecimentos, em lançar um olhar novo sobre eles, em iluminar a tragédia ou a comédia da época do ponto de vista do coro popular rindo na praça pública. Rabelais mobiliza todos os meios das imagens populares lúcidas para extirpar de todas as ideias relativas à sua época $\mathrm{e}$ 
aos seus acontecimentos, a mentira oficial, a seriedade limitada, ditadas pelos interesses das classes dominantes. Ele não crê na sua época, "naquilo que ela diz de si mesma e no que ela imagina ser", mas quer revelar o seu verdadeiro sentido para o povo crescente e imortal (BAKHTIN, 2008, p. 386, grifo do autor, sublinhado nosso).

Tal é a visão proposta na época do Renascimento, pela qual, de acordo com o filósofo da linguagem, Mikhail Bakhtin,

[...] as formas de romance que mencionamos destruíram aquela vertical do além, que tinha decomposto as formas do mundo espaço-temporal e o seu conteúdo qualitativo e vivo. Elas prepararam o restabelecimento da entidade material $\mathrm{e}$ espaço-temporal do mundo num estágio novo de desenvolvimento, mais aprofundado e complicado (BAKHTIN, 1988, p. 281, sublinhado nosso).

Dessa maneira, a função do carnaval medieval, mais do que deslocar, visa a reposicionar conceitos antes intocáveis, aproximando o homem de realidades que antes Ihe eram vedadas, ainda que em períodos determinados e autorizados pelo status quo. Para o autor russo,

As leis, proibições e restrições que determinavam o sistema e a ordem da vida comum, isto é, extracarnavalesca, revogam-se durante o carnaval: revogam-se antes de tudo o sistema hierárquico e todas as formas conexas de medo, reverência, devoção, etiqueta, etc., ou seja, tudo o que é determinado pela desigualdade social hierárquica e por qualquer outra espécie de desigualdade (inclusive a etária) entre os homens e entra em vigor uma categoria carnavalesca específica: o livre contato familiar entre os homens (BAKHTIN, 2005, p. 123, grifo do autor, sublinhado nosso).

A vida dos senhores e os seus modos particulares de ver o mundo são como que carnavalizados, vivendo todos, permanentemente, em uma suspensão da lógica ortodoxa e cartesiana do mundo social formal, já que eles 
vivem todos os dias as suas inversões e peculiaridades. Segundo Bakhtin, os períodos de transgressão autorizada permitidos pelo carnaval da Idade Média e do Renascimento, não constituem representações a que se assiste, mas sim uma vivência em si mesma. Desse modo,

Não se contempla e, em termos rigorosos, nem se representa o carnaval mas vive-se nele, e vive-se conforme as suas leis enquanto estas vigoram, ou seja, vive-se uma vida carnavalesca. Esta é uma vida desviada da sua ordem habitual, em certo sentido uma "vida às avessas", um "mundo invertido" ("monde à l'envers") (Idem, p. 122-123, grifo do autor, sublinhado nosso).

O senhor Henri, em comparação com os demais senhores, é o que apresenta maior número de pontos de contato com uma maneira de ser carnavalizada. Sua proximidade com o absinto respalda seu modo de ser e de estar no mundo, distorcendo e invertendo referenciais. Para ele, tudo parte do absinto e para ele converge: a bebida representa para a personagem, em última análise, o princípio e o fim, o alfa e o ômega.

Na sua visão, todas as coisas são passageiras e de menor importância, exceto o absinto: "E o senhor Henri, enquanto saboreava o absinto, disse ainda: oh, o Eterno" (TAVARES, 2004b, p. 60). Tal idolatria não o impede de perceber os problemas causados pela adição, como no capítulo "O infinito":

[...] há dois dias que não bebo. ... ando a fazer umas medições de um edifício antigo - disse o senhor Henri - e se bebo absinto as medidas do interior da casa ficam quase o dobro das medidas do exterior da casa. ... será possível uma casa ter uma das paredes com uma largura interior de dez metros e por fora medir apenas cinco? ... o meu conceito de infinito é este: uma caixa que por dentro mede $20 \times 10 \times 10$, e que por fora mede $10 \times 5 \times 5$.... o infinito vem no absinto - disse. E o senhor Henri, levantando o dedo indicador da mão, pediu ainda: mais um infinito, por favor. E dos grandes[!] (Idem, p. 43, sublinhado nosso). 
O verde absinto $^{37}$ é representativo, portanto, da bebida transgressora, que supostamente estimula a criatividade, sendo o destilado uma representação do dionisíaco por excelência, associado à proibição e ao que é vedado por lei, além do fato de ter sido cercado por mitos durante décadas.

A oposição das forças dionisíaca e apolínea, tratada anteriormente, e que é prevalente no cronotopo do bar, impulsiona o senhor Henri não só a ingerir grandes quantidades de absinto, como também a colocar tal bebida no centro do seu universo particular, como uma entidade viva e poderosa o suficiente para libertá-lo de todos os problemas, conscientes ou não, chegando mesmo a funcionar como um substituto do Outro, já que ele é incapaz de estabelecer relacionamentos próximos, de desfrutar de uma convivência social regular, ou de cultivar laços afetivos estáveis.

Por conseguinte, tal bebida representa tanto para o senhor Henri que ele não se cansa de tecer-Ihe, sempre que possível, os mais altos elogios: "[...] ... 0 absinto é o melhor estímulo para a cabeça que existe. Por vezes não sei mesmo o que pensa melhor na minha cabeça: se a minha própria cabeça se o absinto. ... mas provavelmente é o absinto [...]" (Ibid., p.16).

Em certa ocasião, ao falar sobre o violino Stradivarius, padrão de excelência entre os violinos, um dos muitos assuntos entre os quais passeia com desenvoltura, o senhor Henri afirma: "[...] ... eu poderia ter sido um grande violinista, mas nunca soube tocar violino. ... porém o álcool apareceu muito antes do violino. ... muito antes de existirem violinistas já existiam pessoas inspiradas artisticamente pelo álcool" (Ibid., p. 21).

Nota-se aí uma possível referência ao fato de que os artistas da Belle Époque, principalmente os escritores e pintores franceses, eram grandes consumidores da bebida, chegando a achar que ela os inspirava em suas

\footnotetext{
${ }^{37}$ A tonalidade verde do absinto, que Ihe conferiu a denominação de "fada verde" (fée verte), remete à Belle Époque, o efervescente período que marcou o fim do século XIX e o início do século XX, sob o resplendor da Revolução Industrial e do revolucionário levante artístico que assinalou o surgimento do Romantismo. Em 1908, por plebiscito popular, foi proibido na Suíça, onde $63,5 \%$ dos eleitores apoiaram a proibição, que foi sancionada em 1910. Outros países acompanharam e, em 1913 os Estados Unidos e quase toda Europa haviam adotado a proibição. Apenas na Espanha, Dinamarca, Inglaterra e em Portugal ainda era permitido o consumo, mas só se a bebida fosse produzida com quantidade limitada de tujona, composto químico presente na planta Artemisia absinthium, a partir da qual é feita a bebida. A edição de 11 de junho de 1911 do Jornal O Estado de São Paulo trouxe a notícia da proibição da fabricação e venda do absinto por uma comissão do senado francês. (Ver Referências.)
} 
criações. Como a vida do senhor Henri está indissoluvelmente ligada ao absinto, o que ele fala aparece também distorcido pela adição à bebida, à qual ele dedica pensamentos e frases de enaltecimento e respeito.

Além de demonstrações de afeto e consideração para com o absinto, o senhor Henri tem, como segunda preocupação, demonstrar seu "saber enciclopédico":

[...] ... debaixo da terra há movimentos de energia que são simétricos aos movimentos num formigueiro. ... e é de uma grande quantidade destes movimentos que nascem os terramotos. ... eu leio diariamente a enciclopédia para poder ter acesso a estas informações imprescindíveis - disse o senhor Henri (Ibid., p. 33, sublinhado nosso).

Para justificar a sua afirmação, o senhor Henri lê diariamente a enciclopédia para se manter informado, como quem lê todos os dias o jornal, fato que, relacionado ao senhor Henri tal como ele se nos apresenta, pode vir acompanhado da dedução implícita de que o conteúdo dessas leituras deve sofrer possíveis alterações em razão do consumo excessivo de álcool. Tal fato, todavia, não atrapalha a sequência explicativa do seu raciocínio, desenvolvido à luz da sua lógica peculiar.

Em "A poesia", a personagem tece conjeturas sobre as duas matemáticas que supostamente existiram em épocas remotas. Trata-se de uma narrativa de tipo mítica, uma criação da imaginação deste senhor, em que as personagens são antropomorfizadas: segundo ele, as duas matemáticas lutaram entre si, e em uma analogia que compara o embate de povos fortes e fracos, prevaleceu a lógica: a matemática mais forte venceu, e a mais fraca, e supostamente mais inteligente, saiu perdedora, em uma nova demonstração da tensão entre as duas forças mencionadas anteriormente.

A partir desta comparação improvável, entre força física e inteligência, o senhor Henri conclui que a matemática derrotada e mais inteligente teria, então, dado origem à poesia, tomando ainda o cuidado de afirmar não ser isso uma certeza, apenas um "cálculo matemático" (p. 37). 
Finda a narrativa, ele prossegue em outro sentido, sem interrupção ou conexão aparentes, ao perguntar aos seus ouvintes - os frequentadores do bar/sala de visitas: "[...] ... querem que vos fale dos fatídicos anos de 1348$50 ?^{38}$ - perguntou ainda o senhor Henri, já perfeitamente desequilibrado" (Ibid., p. 37).

E avança o senhor Henri, em seguida, e sem esperar pela resposta, "para o primeiro múltiplo" (p. 37), em uma guinada fantástica, que parte da origem mítica da poesia, segundo ele próprio, passando à História do período medieval, nos anos que foram especialmente marcados pela peste negra na Europa, chegando, finalmente à Matemática, relativamente à questão dos múltiplos.

Este senhor, diferentemente dos demais, em geral formais no vestir e no uso da linguagem, apresenta outra imagem externa, uma diferente marca carnavalesca de desprendimento comportamental em relação às normas.

Por influência ou não do absinto, ele é o mais liberal no falar e o mais bem-humorado dos senhores, mesmo porque, o cronotopo do bar/sala de visitas favorece tal soltura e liberalidade. Quanto aos gestos e às vestimentas, este senhor foge ao padrão dos demais senhores, ao denotar descuido tanto no vestir como no comportamento em público:

O senhor Henri cocou depois a barriga com o dedo indicador da mão direita. O senhor Henri tinha umas calças pretas que não chegavam aos sapatos. 0 senhor Henri tinha uns sapatos castanhos antigos. $E$ estes, vindos de baixo, também não chegavam às calças. Era, portanto, mútuo: as calças não chegavam aos sapatos e os sapatos não chegavam às calças (Ibid., p. 13, sublinhado nosso).

Suas falas, além da amplidão de assuntos e da pseudoerudição, vão de teorias esdrúxulas, verbalizadas como absolutamente plausíveis, a enumerações grotescas, típicas do cronotopo de Rabelais, o qual abarca um

\footnotetext{
${ }^{38}$ Os anos de 1348-1350 correspondem ao auge do período da peste negra na Europa. (Ver Referências.)
} 
tempo coletivo, de características comunitárias e folclóricas, em que o tempo, segundo Bakhtin,

[...] é medido apenas pelos acontecimentos da vida coletiva. Tudo o que nele existe, existe somente para o coletivo. A série individual da existência ainda não tinha se destacado (o tempo interior da vida individual ainda não existe, o indivíduo vive totalmente do lado de fora, num todo coletivo). Tanto o trabalho como o consumo são coletivos (BAKHTIN, 1988, p. 317, grifo do autor, sublinhado nosso).

Tal como na Idade Média e no início do Renascimento, também o senhor Henri vive uma vida externa, coletiva, em que todos os frequentadores do cronotopo bar/sala de visitas testemunham seus atos e palavras. O ambiente comunitário deste cronotopo é o tempo/espaço onde se desenrola sua vida, no qual todos os assuntos são tratados diante de todos, e em que as verdades são reveladas pelo senhor Henri, a partir dos mais diversos assuntos e temas.

Não há monólogo interior. Suas falas são proferidas em voz alta, em diálogos consigo mesmo ou falando para o Outro, que provavelmente não 0 escuta. Ele procede como um palestrante em quase todos os momentos do dia. O narrador onisciente apenas localiza de forma sucinta a personagem em um tempo/espaço determinado, iniciando com a frase introdutória, que é quase sempre: "O senhor Henri disse". Não há espaço para outras falas, apenas as do verborrágico e irreverente senhor Henri.

A vida deste senhor corre em paralelo ao que se supõe seja a vida regular dos demais habitantes dO Bairro, com exceção dos senhores, personagens nas quais se revelam vidas "pelo avesso", por suas particularidades e idiossincrasias.

Quanto ao senhor Henri, emerge mais claramente do que nas outras personagens de Os Senhores o papel caricatural do indivíduo que escapa das normas sociais, do status quo oficial do sistema, e que, devido à sua embriaguez permanente, é aceito dentro do próprio sistema como uma forma aberrante, porém autorizada. 
Nesse sentido, há uma aproximação do que vive o senhor Henri, em relação ao carnaval e a outras celebrações medievais realizadas na praça pública. Para Mikhail Bakhtin,

Todos esses ritos e espetáculos organizados à maneira cômica apresentavam uma diferença notável, uma diferença de princípio, $[\ldots .$.$] , em relação às formas do culto e às cerimônias$ oficiais sérias da Igreja ou do Estado feudal. Ofereciam uma visão do mundo, do homem e das relações humanas totalmente diferente, deliberadamente não-oficial, exterior à Igreja e ao Estado; pareciam ter construído, ao lado do mundo oficial, um segundo mundo e uma segunda vida aos quais os homens da Idade Média pertenciam em maior ou menor proporção, e nos quais eles viviam em ocasiões determinadas. Isso criava uma espécie de dualidade do mundo [...] (BAKHTIN, 2008, p. 4-5, grifo do autor, sublinhado nosso).

Assim, o bar funciona para o senhor Henri como um palco, em que ele é o único ator, constituindo os frequentadores e os atendentes meros coadjuvantes, ou apenas a plateia indiferente do senhor Henri. Os conteúdos por ele desenvolvidos apresentam uma roupagem carnavalizada, seja pela não veracidade, seja pelas associações ilógicas, do ponto de vista da ortodoxia.

O conhecimento formal acadêmico não rasurado corresponde à visão oficial, da qual o senhor Henri não compartilha, já que o seu mundo é eminentemente carnavalizado e próprio, mesmo que inserido no mundo regular. Tal dualidade é vivida de modo permanente pela personagem, diferentemente das representações cômicas medievais e renascentistas, cujas transgressões eram autorizadas durante um período específico. No caso do senhor Henri, não the é concedida tal licença temporalmente limitada, já que ele vive transgressivamente e por vontade própria em todos os momentos, dentro e fora do bar.

De acordo com os estudos bakhtinianos sobre a obra de François Rabelais (2008), as enumerações grotescas são parte fundamental na construção de seus enredos, além da utilização rebaixada da linguagem, 
próprias das personagens desse autor, e de que igualmente faz uso o senhor Henri.

Em "O medicamento", no momento em que engole uma aspirina no bar, o senhor Henri enumera as dores prováveis e improváveis, plausíveis e absurdas, físicas e não físicas, que seriam supostamente aliviadas pelo remédio em questão:

Uma aspirina, disse o senhor Henri, enquanto engolia uma. [...] ... serve para as dores de cabeça, dores nas mãos e nos dedos dos pés, dores de corno, dores de cotovelo, dores de coração, dores de alma, dores do espírito santo de orelha, dores de dentes, dores de gengivas, dores nas unhas demasiado compridas, dores no pensamento, dores nas conclusões, dores na carteira, dores nas hipóteses, dores na mulher do outro, dores no mandamento não cobiçarás a mulher do outro, dores na pilinha ${ }^{39}$, dores nos testículos, dores no rabo, nas nádegas, nos sovacos, nos pelos dos sovacos, dores na uretra, dores nos seios no caso das mulheres, dores no cabelo quando nos puxam, dores em todo o lado Nosso-Senhor-nos-acuda. E também para a asma. $O$ senhor Henri, entretanto, depois de uma pausa para recuperar o fôlego, pediu um copo de absinto. Um velho que estava ao lado comentou: só não percebo para que é a aspirina. É para ajudar nos efeitos, respondeu de imediato o senhor Henri (TAVARES, 2004b, p. 29-30, sublinhado nosso).

As maldições, a linguagem chula, as blasfêmias, as imagens ligadas às partes do corpo e às funções fisiológicas fazem parte do acervo temático do cronotopo rabelaisiano, integrando igualmente o repertório do senhor Henri, e apresentando, como função principal, a exposição de elementos que se tornam cômicos ao serem deslocados de seus contextos canônicos originais, cujo uso

${ }^{39}$ pilinha: diminutivo de pila, s. f. Lus. pênis de criança. FERREIRA, Aurélio Buarque de Holanda. Novo Aurélio Século XXI. Rio de Janeiro: Nova Fronteira, 1999, p. 1565. 
cria um contraponto ao sério, ao formal e ao ortodoxo, representados pelo sistema estabelecido e pelas instituições oficiais.

Desse modo, o senhor Henri afirma:

[...] ... eu tenho quase tantas necessidades intelectuais como fisiológicas. ... se eu contabilizar as vezes que a urina me acorre ao vaso de baixo, e as vezes que a vontade de saber factos me acorre ao vaso de cima, decerto que a contabilidade de cima será bem superior à de baixo. ... e isto já tendo em consideração que o absinto apela muito à liquidez (Idem, p. 7879, sublinhado nosso).

Em outra narrativa, o senhor Henri utiliza um recurso comumente usado por Rabelais, que são as maldições e esconjurações. Tal se dá quando este senhor lança ameaças a priori àquele que ousar fechar o bar, ambiente que é objeto do seu apreço: "[...] quem um dia fechar a porta de tão honrado estabelecimento que seja amaldiçoado por 100 mil demónios coxos e por uma bruxa triplamente feia. ... e um copo de absinto, por favor" (Ibid., p. 57, sublinhado nosso).

De acordo com Mikhail Bakhtin,

A função do grotesco é liberar o homem das formas de necessidade inumana em que se baseiam as ideias dominantes sobre 0 mundo. $O$ grotesco derruba essa necessidade e descobre seu caráter relativo e limitado. A necessidade apresenta-se num determinado momento como algo sério, incondicional e peremptório. Mas historicamente as idéias de necessidade são sempre relativas e versáteis. $\underline{0}$ riso e a visão carnavalesca do mundo, que estão na base do grotesco, destroem a seriedade unilateral e as pretensões de significado incondicional e intemporal e liberam a consciência, o pensamento e a imaginação humana, [...] (BAKHTIN, 2008, p. 43, grifo do autor, sublinhado nosso).

É de ressaltar que há uma correlação proporcionalmente qualitativa entre os valores que são conferidos às coisas e às dimensões espaço- 
temporais no cronotopo rabelaisiano. Assim, "[...] tudo o que é precioso, qualitativamente positivo, deve realizar sua importância qualitativa na importância espaço-temporal [...]" (BAKHTIN, 1988, p. 282-283).

Segundo o teórico russo, "Entre um valor, qualquer que seja ele comida, bebida, verdade, bondade, beleza - e as dimensões espaçotemporais, não há hostilidade recíproca, não há contradição, elas são diretamente proporcionais umas às outras" (Idem, p. 283).

Prossegue Bakhtin, seguindo o raciocínio proposto:

Falando sobre a proporcionalidade direta, nós, absolutamente não temos em vista que a qualidade, e a sua expressão espaço-temporal, no mundo de Rabelais estivessem desunidas de início, para se reunirem depois; ao contrário, elas estão ligadas desde o começo na unidade indissolúvel de suas personagens. Mas estas imagens estão propositalmente opostas à desproporcionalidade da visão do mundo da lgreja feudal, cujos valores são hostis à realidade espaço-temporal como a um princípio fútil, frágil e pecaminoso, onde o grande é simbolizado pelo pequeno, o forte pelo fraco e pelo impotente, o eterno pelo instante que passa (Ibid., p. 283, sublinhado nosso).

Para o senhor Henri, sendo o tempo/espaço do bar algo fundamental para a sua vida, é aí que ele manifesta a sua visão carnavalizada do mundo, ligando por associações estapafúrdias um tema a outro, destacando a importância de detalhes que passariam despercebidos, ou não mereceriam comentários, em um processo de inversão próprio do cronotopo rabelaisiano.

Em outra instância, observa-se que a personagem encaminha seus raciocínios não apenas para a expansão de grandezas quantitativas e de dimensões espaço-temporais, mas também no sentido inverso: para a compressão e a redução dos mesmos sentidos quantitativos e dimensionais, nos moldes do cronotopo de Rabelais:

[...] ... se por cada vez que bebi um copo de absinto nesta excelentíssima biblioteca tivesse lido um livro nas outras 
bibliotecas, já saberia de cor a história inteira dos Visigodos. ... o problema é que há mais povos que cerejas, e se eu aprendo a história toda dos Visigodos, perco o tempo necessário para estudar a história dos Ostrogodos, que por acaso não existem. ... o melhor era reunirem todos os factos e todos os acontecimentos num livro, e depois reduzirem este livro a metade do tamanho, e assim sucessivamente, até conseguirem pôr todos os conhecimentos do mundo numa frase de dez palavras (TAVARES, 2004b, p. 78, sublinhado nosso).

A ligação do cronotopo rabelaisiano original com a vida externa e coletiva é marcada, na narrativa tavariana, e segundo modificações, pelo desenrolar do cotidiano do senhor Henri, principalmente no tempo/espaço do bar, o qual, como a praça pública, é de acesso coletivo. Além disso, há que se acrescentar o fato de que, do mesmo modo que na praça carnavalesca, o cronotopo do bar/sala de visitas é um ambiente propício ao relaxamento e às celebrações, oficialmente motivadas ou não.

Aí as bebidas desempenham um importante papel no sentido da liberação das emoções, que, no estado de sobriedade, provavelmente não seriam demonstradas tão abertamente. Nesse sentido, é a relação têmporoespacial o fator determinante a conferir forma e conteúdo à personagem, às suas falas e ações, como desenvolvido no Capítulo I.

No cronotopo original de Rabelais, há um desenvolvimento cíclico da vida, que coloca o homem e o seu trabalho frente às adversidades da natureza, as quais ele deve sobrepujar, sem praticamente nenhum espaço reservado à meditação, à contemplação, e à poesia. De acordo com o pensamento e as formulações teóricas de Bakhtin sobre esse cronotopo:

Somente nesse processo o homem se encontra com elas (as coisas do mundo concreto), e somente através do prisma desse processo ele toma consciência delas e conhece-as. (Este conhecimento é mais realístico, objetivo e profundo do que seria nas condições de uma vã contemplação poética). É por isso que todos os objetos estão integrados no movimento da vida, nos acontecimentos da vida como seus participantes 
vivos. Eles tomam parte do enredo e não estão contrapostos às ações, como se lhes servissem de fundo (BAKHTIN, 1988, p. 319-320, sublinhado nosso).

Quanto ao universo do senhor Henri, essencialmente prático e voltado para a realidade circundante, tal concretude se dá pela exposição do seu "conhecimento" histórico e científico nos lugares que frequenta, independentemente do fato de isto ser adequado ou não. Indivíduo não dado à contemplação poética ou a divagações filosóficas, este senhor cultiva o gosto por fatos concretos e pela "precisão" narrativa dos mesmos: eventos, descrições imagéticas, passagens históricas, nomes, números e datas - não importando se são ou não verídicos. A imagem, portanto, que o senhor Henri tem de si mesmo é a de um intelectual, o que se pode notar a partir da analogia que ele faz ao comparar o cérebro - "o vaso de cima" -, e a bexiga - "o vaso de baixo":

[...] ... no entanto há muito tempo que não me consigo concentrar totalmente nos meus copos de absinto devido às minhas necessidades intelectuais. [...]. [...] ... por mais estranho que vos possa parecer, no fim do ano eu apresento um claro défice no vaso de baixo. ... com mais solicitação intelectual que fisiológica não há dúvida nenhuma de que, afinal, me posso incluir na categoria dos intelectuais (TAVARES, 2004b, p. 7879, sublinhado nosso).

Também o riso, o cômico e o descabido desempenham importante função narrativa em $\mathbf{O}$ senhor Henri, encarnando, ele próprio, os papéis do bobo e do bufão para a "plateia" de frequentadores do bar, e também para os que, possivelmente, o observam em outros lugares, como um indivíduo falante e extrovertido, permanentemente inebriado pelo efeito do absinto.

As falas do senhor Henri, citadas abaixo, tentam em vão ser fiéis, tanto do ponto de vista qualitativo como quantitativo, buscando ele conferir veracidade e concretude às suas elaborações. As partes sublinhadas nas citações abaixo são nossas: 
"[...] a estatística foi inventada em Londres em 1662" (p. 13);

"[...] já os babilônios tinham um calendário, 600 anos antes de Cristo! [...]. Li na enciclopédia: 530 anos antes de Cristo! 530 é o número correcto. Temos de ser exactos nas datas, disse o senhor Henri, [...]" (p. 19);

"[...] ... foi feito um estudo que provou que a inteligência se situa principalmente na parte de cima do absinto" (p. 69).

É de ressaltar que, no cronotopo rabelaisiano, desenvolvem-se séries organizadas de elementos da mesma natureza, ou de naturezas diversas, dispostas paralelamente ou de forma cruzada. Segundo Mikhail Bakhtin, "Com a ajuda delas Rabelais compõe e decompõe. A elaboração das séries é uma particularidade específica do método literário de Rabelais" (BAKHTIN, 1988, p. 285, grifo do autor).

Ainda segundo o teórico russo, tais séries desempenham a importante função de expor, no caso do corpo humano, "[...] toda a complexidade e profundidade extraordinárias do corpo e da vida do homem, e revelar o novo significado, o novo lugar do corpo humano num mundo real, espaço-temporal" (Idem, p. 285, sublinhado nosso).

Ao referir-se ao cronotopo de Rabelais e à mudança ideológica do mundo medieval em relação ao do Renascimento, no que toca ao corpo humano e às suas funções, Bakhtin prossegue:

Este novo quadro do mundo opõe-se polemicamente ao mundo medieval, em cuja ideologia o corpo humano é concebido somente sob o signo da corrupção e da aniquilação, em cuja prática cotidiana real reina uma licenciosidade corpórea, grosseira e suja. A ideologia não explicava nem comentava a vida corporal, ela a negava; portanto, desprovida de palavra e de sentido, a vida carnal só podia ser licenciosa, grosseira, suja e autodestrutiva. Havia um abismo incomensurável entre a palavra e o corpo. [...]. Ele quer devolver ao corpo a palavra e ao sentido a sua realidade e materialidade (Ibid., p. 285, sublinhado nosso). 
Com referência ao senhor Henri, as séries cobrem temas essencialmente concretos, ligados ao corpo, aos fatos históricos, aos inventos científicos, a datas e números. Assim, o "intelectual" senhor Henri discorre sobre ossos e anatomia, eras históricas, datas de invenções, instrumentos musicais, plantas, eclipses e terremotos, conhecimentos estes, provenientes da enciclopédia. É de se concluir, pois, que as referências do senhor Henri são eminentemente pretéritas, vivendo ele de todo distanciado dos fatos que ocorrem no mundo presente, já que não lê jornal nem tem acesso a outras mídias.

É como se as suas divagações e teorias estivessem mergulhadas em absinto, sofrendo distorções e desvios próprios da embriaguez. Todavia, esta é a maneira encontrada pela personagem para, de certa forma, anestesiar-se de sua solidão e pôr no lugar de seu vazio interior algo que lhe permita apropriarse, organizadamente, de um acervo de "conhecimentos" e do mundo à sua volta.

Os frequentadores do bar e os balconistas, provavelmente pouco 0 escutam, possivelmente cansados da prolixidade do "erudito" freguês, ou por estarem mergulhados, tal como ele próprio, em acentuado torpor etílico.

Todavia, o senhor Henri não aparenta tristeza, sendo todas as suas narrativas pontuadas por humor, mesmo que de natureza irônica e nem tão velada, mas, ainda assim, diferentemente do que ocorre no cronotopo de Rabelais, em que o riso é mais aberto e debochado. Em "A poesia”, revelamse, além do humor contido, a questão ritualística que obriga os senhores a cumprir ações correspondentes de lateralidade e simetria, garantidoras de uma pseudossegurança e de um ponto de relativo equilíbrio:

Depois de beber, de uma só vez, o copo de absinto que segurava na mão direita, o senhor Henri pediu: outro copo de absinto. ... é para os dois lados do corpo - disse. - Este segundo é para a mão esquerda. E segurando com a mão esquerda bebeu o segundo copo. ... é fundamental para o equilíbrio de um homem (TAVARES, 2004b, p. 35, sublinhado nosso). 
Dos recursos de ordenamento utilizados pelo senhor Henri, a enciclopédia é o que mais se aproxima de uma organização formal, à qual ele recorre diariamente como fonte de aprendizado e norteamento, em oposição ao caos representado pelo uso da bebida: "[...]. ... também sei coisas sobre astronomia e alquimia. ... soube primeiro coisas de alquimia do que de astronomia, por causa do alfabeto. ... para mim, mais importante que a ordem histórica é o L surgir antes do $S$ - disse o senhor Henri" (Idem, p. 50).

Além disso, ao mencionar fatos históricos e científicos, mesmo que alterados, o senhor Henri estabelece outro referencial de segurança, que é a manutenção da historicidade, ainda que relativa, e da tradição da transmissão oral do conhecimento, em uma dimensão têmporo-espacial concreta e organizada, ou seja, aquela constituída por eventos que surgiram antes dele e de outros que virão depois.

Para o senhor Henri, o bar, o absinto, os devaneios e delírios etílicos, a transgressão e a liberdade criativa, elementos representativos da esfera dionisíaca, caminham em paralelo ao conhecimento formalmente organizado da enciclopédia. Não há aí tensão nem embate, mas uma convivência harmoniosa, mediada por seu desejo de convívio com o Outro. Reforçando tal ideia, o senhor Henri, em certa instância, comenta: "[...] ... há, no entanto, coisas eternas, é claro, ... coisas que nunca morrem. ... coisas que nunca perdem o valor" (Ibid., p. 60).

O comentário do senhor Henri é denotativo, pois, desse continuum histórico, que o permite sentir-se integrado a algo perene e maior do que o seu pequeno mundo. 


\section{CAPÍTULO III}

\section{O DISCURSO DO LIMIAR}

A análise de Os Senhores, neste capítulo, é feita tendo em vista as peculiaridades da obra de Gonçalo M. Tavares, isto é, levando em conta as maneiras pelas quais os aspectos morfológicos, sintáticos, semânticos e estilísticos ajudam a compor alguns dos possíveis sentidos propostos pela obra.

Como um constructo complexo, em se tratando especialmente da obra do autor em questão, há que se proceder a uma análise, a meu ver, em seus componentes mais importantes e representativos no que se refere ao estudo dos elementos discursivos.

Ouso modestamente compartilhar, de forma geral, da visão de Todorov (2006, p. 20, grifo do autor), quando diz que a obra literária, de um modo ou de outro,

[...] participa de uma rede de relações entre ela mesma e as outras obras do mesmo autor, da mesma época, do mesmo gênero. Se se dá à palavra gênero um sentido generalizado, poder-se-ia dizer que a obra nunca existe fora do gênero: quer seja um gênero "pessoal" (constituído por todas as obras do escritor) ou "temporal" (pelas obras de um período) ou "tradicional" (como a comédia, a tragédia, etc.).

Ressalvo, porém, que, a obra Os Senhores representa algo de substancialmente novo e criativo em termos narrativos, tanto do ponto de vista da organização do enredo como da forma e do sentido geral, que se podem desdobrar em muitas vertentes interpretativas.

Os textos que compõem as narrativas, dada a sua clareza de vocabulário e estruturas, à primeira vista parecem simples. Todavia, faz-se 
necessário um aprofundamento investigativo para perceber que, embora do ponto de vista denotativo, o enredo aparente ser facilmente decodificável no geral, a densidade do conteúdo obriga a um olhar mais cuidadoso.

A mais importante razão para isso se apoia no fato de que, em se tratando os senhores de sujeitos que se poderia caracterizar como do limiar, da crise iminente, do impasse, há um reflexo destes estados psicológicos no uso da língua que os descrevem, e que se torna específico na narrativa de cada senhor.

Vale ressaltar aqui que a análise que se segue não tratará apenas de aspectos linguísticos, em sentido estrito, mas do discurso como um todo, em que se integram elementos dialógicos que ultrapassam a esfera da linguística tradicional, da estilística e da gramática normativa, tomando-se para este estudo, inclusive, a acepção de metalinguística, conforme adotada por Mikhail Bakhtin (2005, p. 185), por meio da qual se analisam a estilização e a paródia, bem como as relações dialógicas, levadas em conta as réplicas dos diálogos.

Atenção especial será dada à análise dos discursos das personagens e do narrador, no sentido de clarificar elementos do próprio discurso, no que isto representa de fundamental para uma melhor compreensão da obra como um todo.

Além das obras de Mikhail Bakhtin, servem de suporte teórico para o desenvolvimento deste capítulo duas obras de Tzvetan Todorov: As estruturas narrativas (2006) e Poética da prosa (2003), bem como obras de outros autores que dão, em diferentes momentos, valioso suporte ao estudo.

Segundo o teórico russo,

Apesar das diferenças substanciais, todos esses fenômenos têm um traço comum: aqui a palavra tem duplo sentido, voltado para o objeto do discurso enquanto palavra comum e para um outro discurso, para o discurso de um outro. Se desconhecermos a existência desse segundo contexto de discurso do outro e começarmos a interpretar a estilização ou a paródia como interpretamos o discurso comum voltado exclusivamente para o seu objeto, não entenderemos verdadeiramente esses fenômenos: a estilização será 
interpretada como estilo, a paródia como obra má (BAKHTIN, 2005 , p. 185, grifo do autor, sublinhado nosso).

$\mathrm{Na}$ medida em que a língua se concretiza na fala específica de cada senhor, o exame que leva à interpretação das falas merece ser investigado nos elementos que conduzem ao efeito comunicativo e dialógico final, revelando, em última instância, o estado de crise latente em que vivem as personagens de Gonçalo M. Tavares.

Proceder-se-á, ainda, a um exame dos protogêneros, que constituem a matriz dos gêneros em prosa, os quais se desenvolveram a partir desses protótipos, desde o diálogo socrático e a menipeia, até os romances gregos da Antiguidade, em seu desenvolvimento posterior, sem perder de vista a questão primordial dos cronotopos, determinantes das vozes discursivas e da diegese, bem como a questão social do discurso em suas possíveis interrelações dialógicas, não apenas no âmbito das personagens, mas também dos interdiscursos que a obra estabelece com outras obras e elementos da cultura.

Nesse sentido, serão examinadas as interações dialógicas e de comportamento dos senhores, uma vez que cada um, à sua maneira, usa de recursos e meios próprios no sentido de convencer o leitor, a si mesmo e às demais personagens com quem tem contato acerca da sua verdade particular. Estão, pois, nos movimentos de fala, de comportamento e de interação dos senhores com o Outro as pistas para a elucidação dos modos pelos quais significantes e significados se combinam para atingir tal objetivo.

Por serem os senhores eminentemente visuais e plásticos em suas características físicas e em suas ações, o que primeiro aflora na obra são as imagens que se consegue perceber a partir das descrições de aspectos externos, feitas pelo narrador onisciente e pelas próprias personagens, bem como as reações dos outros habitantes dO Bairro, que as veem de fora.

O senhor Calvino, por exemplo, é essencialmente um indivíduo que caminha incansavelmente pelas ruas da cidade. A busca do Outro e de si mesmo, assim como de um sentido para a vida são, em larga medida, figurativizados a partir de suas andanças e interações com pessoas e objetos. 
A partir do exame seletivo de elementos morfológicos, sintáticos e semânticos da obra, é possível construir um roteiro de análise, o qual descreve este senhor nos aspectos ligados às questões referentes à sua imagem no espaço, à busca de uma identidade, e ao encontro com a alteridade.

Nessa narrativa e do ponto de vista morfológico, predominam substantivos e adjetivos, que funcionam como descritores físicos de objetos e atos, e que são usados de modo econômico e objetivo.

A abertura do quarto capítulo, "O balão", coloca o leitor diante de uma imagem inusitada dentro da lógica do mundo social como o conhecemos: "Calvino certas vezes andava a semana inteira pela cidade levando consigo um balão bem cheio" (TAVARES, 2007c, p. 15). O desenvolvimento do parágrafo complementa a ideia inicial, combinando substantivos e adjetivos reveladores de aspectos comportamentais do senhor Calvino, que ultrapassam o nível comunicativo imediato relativo à personagem.

No curto período mencionado acima é possível identificar uma imagem, na qual, homem e objeto - o balão - formam um todo. A característica externa do balão - "bem cheio" - (p. 15) compõe a cena, que é quase pictórica.

Os substantivos e adjetivos descrevem o cotidiano deste senhor (p. 15), em que as suas atividades seguem normais e diárias como sempre, a despeito do balão, refletidas nos percursos matinais; no cumprimento dirigido aos passantes: o alto e convincente Bom dia!; nos gestos necessários ao seu trabalho; na alimentação regrada do jantar e na alimentação sem-juízo e norma do almoço; nos horários e na pontualidade baseados em um rigor clássico; na conservadora e discreta forma de vestir e sorrir.

Para qualquer indivíduo, tudo poderia ser caracterizado como habitual não fosse pelo balão, o elemento intrusivo na cena, que compõe o desenho psicológico ambivalente do senhor Calvino, um indivíduo carente do ponto de vista afetivo, que utiliza o objeto como elemento substitutivo do Outro.

Homem e balão, tomados separadamente, não causariam surpresa. Há, todavia, como efeito final, ao serem as duas entidades reunidas na ação de um homem que caminha levando pela cidade um balão, uma composição 
imagética que responde não apenas pela visão externa da personagem, mas, e principalmente, serve para caracterizar o tipo de pessoa que é o senhor Calvino, do ponto de vista psicológico e comportamental.

Sendo um homem essencialmente extrovertido e romântico, ele é capaz de pedir, na mercearia, "Maçãs mais rosadas que as meninas ingênuas" ( $p$. 15). Seu comportamento, ao caminhar vários dias pela cidade carregando um balão preso ao pulso por um fio, configura-se, no mínimo, exótico e incompatível com o espaço público.

Sua própria ingenuidade, assumida por ele como sendo das meninas, ao compará-las com maçãs rosadas, é, para ele, algo que se pode assumir como aceitável, dada a sua visão cândida e pueril da vida. Um homem feito, que, por sua carência, apresenta um comportamento quase infantil, ele próprio na fronteira psicológica e afetiva que separa a vida adulta do mundo da criança, comportamento esse provavelmente causado pela falta de contato com a alteridade.

Seus cuidados com o balão, para que nada de ruim the aconteça, revelam-se igualmente nos substantivos e adjetivos (p. 16-17), que estabelecem conexão descritiva com o objeto: delicadeza, jarra frágil num tampo instável, atenção invulgar, exercício fundamental, sistema simples, camada fina de látex, pequenina parte da totalidade de ar do mundo, camada colorida, insuperável fragilidade, conjunto de gestos protetores, enorme e forte vida, enorme e forte morte.

De todas as expressões usadas, sobressai-se a oposição que justifica, em síntese, a razão primordial do cuidado da personagem com o balão, representativo, ele próprio, do limiar em que ela se coloca, ciente da "pequena distância que existe entre a enorme e forte e vida que ele agora possuía e a enorme e forte morte que andava sempre, como um inseto desconhecido mas ruidoso, a cada momento a circular em seu redor" (Idem, p. 17, grifo nosso). Vida e morte são aí elementos de igual peso, a lembrar-lhe da sua condição mortal de ser tão frágil quanto o balão.

As dualidades bem como as ambiguidades constituem o universo do senhor Calvino, para quem as coisas estão sempre entre extremos: fazer tudo 
ou a metade de tudo (p. 54), ou ainda, descrever de modo imperfeito a exatidão (p. 54). Tal fato não exclui o seu gosto pela surpresa - o imponderável: "Para ele era indispensável uma irregularidade inicial, um pé em falso, a incapacidade para compreender uma parte, uma expectativa por um fato surpreendente. Olhou em volta. Nada. Tudo como previsto" (Ibid., p. 54).

Todos os senhores, de modos diversos, se colocam entre oposições, em um jogo de oxímoros ${ }^{40}$ peculiar a cada um. Também o senhor Valéry, situado entre dualidades e oposições, tem a sua vida metodicamente ritualizada, o que inclui igualmente os extremos existenciais: o medo da morte e a insegurança, que se opõem à ideia de vida.

Para o senhor Brecht, o próprio cronotopo do limiar em "Hesitação", caracteristicamente representado por uma escada, apresenta, implicitamente, um jogo de oxímoros: "O homem no meio da escada hesitava há vários dias entre subir e descer. Os anos passavam e o homem continuava a hesitar: subo ou desço? Até que certo dia a escada caiu" (TAVARES, 2005, p. 64).

Observam-se aí os opostos do subir e descer, a hesitação e a decisão, a vida e a morte implícitas, o estar imóvel no meio da escada e a queda. No caso, o fato de a personagem situar-se no meio da escada, em dúvida quanto à decisão a tomar, metaforiza a situação de impasse em que o indivíduo, como em uma encruzilhada, deve decidir o caminho a ser trilhado ou a escolha a ser feita nos momentos das grandes decisões. A escada é aí, pois, representativa do tempo/espaço da crise, conforme mencionado anteriormente neste trabalho.

Segundo Bakhtin, "O alto, o baixo, a escada, o limiar, a sala de espera e o patamar assumem o significado de ponto em que se dão a crise, a mudança radical, a reviravolta inesperada do destino, onde se tomam as decisões,

\footnotetext{
${ }^{40}$ oxímoro: Segundo Massaud Moisés, o oxímoro é uma "Figura de linguagem (que) consiste na fusão, num só enunciado, de dois pensamentos que se excluem mutuamente. Pode formarse de palavras, frases ou orações contrastantes ou antônimas" (Ducrot e Todorov, 1972: 354), cujo encontro gera paradoxo, motivado pela "tensão entre o portador da qualidade (substantivo, verbo, sujeito) e a qualidade em si (atributo, advérbio, predicado)"; "tensão entre qualidades (adjetivos, advérbios)"; pela distinctio enfática, que afirma a existência e a inexistência simultâneas de uma mesma coisa" (Lausberg, 1972: 230-231). Espécie de antítese reforçada ou concentrada, o oxímoro caracteriza-se, estruturalmente, pela combinação, numa unidade sintática, de duas declarações antagônicas, [...]. (Ver Referências.)
} 
ultrapassa-se o limite proibido, renova-se ou morre-se" (BAKHTIN, 2005, p. 171-172, grifo do autor).

O senhor Juarroz, por seu turno, é um homem dos espaços internos e de hábitos reservados, apreciador da previsibilidade e do controle, diferentemente do senhor Calvino. Entre a realidade concreta e observável e os pensamentos, ele prefere o mundo da sua imaginação, evitando contato com o meio circundante sempre que possível.

Os textos que enunciam as falas do narrador onisciente e as falas da personagem são econômicos de adjetivos, como se o senhor Juarroz se ativesse apenas ao mínimo essencial do mundo externo, refletindo suas ideias e opiniões uma visão quase esquemática. Em "Objeto no telhado", tal pode ser observado, quando a esposa o incita a entrar no elevador:

A esposa do senhor Juarroz começava a ficar irritada. Sobes ou não? O senhor Juarroz, porém, nada ouvia e nada via porque estava a pensar:

- a invenção da máquina de lavar roupa permite que um cidadão deixe de lavar roupa com as mãos;

- a invenção do telefone evita que o cidadão percorra grandes distâncias só para dar um recado;

- a invenção da escada permite que um cidadão não necessite de subir lá em cima (TAVARES, 2007a, p. 19).

Ou ainda: "O senhor Juarroz insistia em manter na casa uma gaveta para guardar o vazio. Costumava até a dizer esta estranha frase: Quero encher esta gaveta de vazio" (Idem, p. 13).

O discurso na narrativa do senhor Juarroz espelha, portanto, sua maneira de ver o mundo e de raciocinar, ou seja, em tópicos, sem rodeios, deixando claro, ao menos para si mesmo, o que deseja transmitir.

De modo diferente e com mais volteios discursivos, o senhor Calvino, bem como o narrador onisciente, expressam as ideias da personagem em uma linguagem minuciosa, longa e digressiva, pontuada por grande número de detalhes: 
Por vezes, emocionava-se com as ideias, não com o mundo. Ter vida própria não era para o senhor Calvino - apenas passar por experiências atribuladas no jogo das aproximações e afastamentos humanos, para ele quem não tinha pensamentos próprios não tinha vida própria. Calvino sentia uma idéia a passar pela cabeça como sentia o frio na garganta; claro que tal sensação não era tocável como uma peça de mobília, era uma sensação efêmera, no entanto excitante. Em determinados dias, o seu cérebro emocionava-o o suficiente, $\mathrm{e}$ por isso podia evitar outras emoções circunstanciais. Pelo menos, aquelas eram controláveis. Lembrava-se bem, aliás, da infelicidade que acontecera a um seu amigo que, como tinha uma paralisia facial, estava sempre a rir, acontecesse o que acontecesse [...]. (Ibid., p. 53, grifo nosso).

Do trecho acima, é possível observar as minúcias e os detalhes descritivos, as divagações e digressões de que é capaz o senhor Calvino, por meio do narrador onisciente, preenchendo ele mesmo o seu mundo íntimo com o que the falta na vida cotidiana. Os adjetivos frequentes buscam igualmente detalhar as nuances de pensamento deste senhor: vida própria / experiências atribuladas / jogo das aproximações e afastamentos humanos / pensamentos próprios / sensação efêmera e excitante / emoções circunstanciais / emoções controláveis (p. 53).

Também os verbos indicam as particularidades emotivas e o modo de ser romântico do senhor Calvino: emocionar-se com as ideias, não com o mundo/ passar por experiências atribuladas no jogo das aproximações e afastamentos humanos / não ter pensamentos é não ter vida própria / sentir uma ideia a passar pela cabeça em comparação com sentir o frio na garganta / o cérebro se emocionar o suficiente para evitar outras emoções circunstanciais (p. 53).

Para o senhor Calvino, o ato de comparar é essencial para exprimir com fidelidade suas ideias e sentimentos. Desse modo, desde comparar maçãs mais rosadas que as meninas ingênuas ( $p .15$ ), ele também compara a morte a um inseto desconhecido mas ruidoso (p. 17). Seguem-se outras 
comparações: o A da sopa preso ao queixo comparado a um alpinista ( $p$. 21) / as ideias que pingam da sua cabeça como de um pote de água furado (p. 23).

Os meandros e floreios da linguagem do senhor Calvino se estendem ao seu caminhar. Se ele está adiantado ou não em relação a um compromisso, seu percurso na rua é variável, como mostra a sequência de imagens ${ }^{41}$ : "[...] quando sabia que estava adiantado para um encontro não alterava o percurso, mas sim a trajetória nele. Não parava. la pela mesma rua, mas de maneira diferente" (Ibid., p. 56).
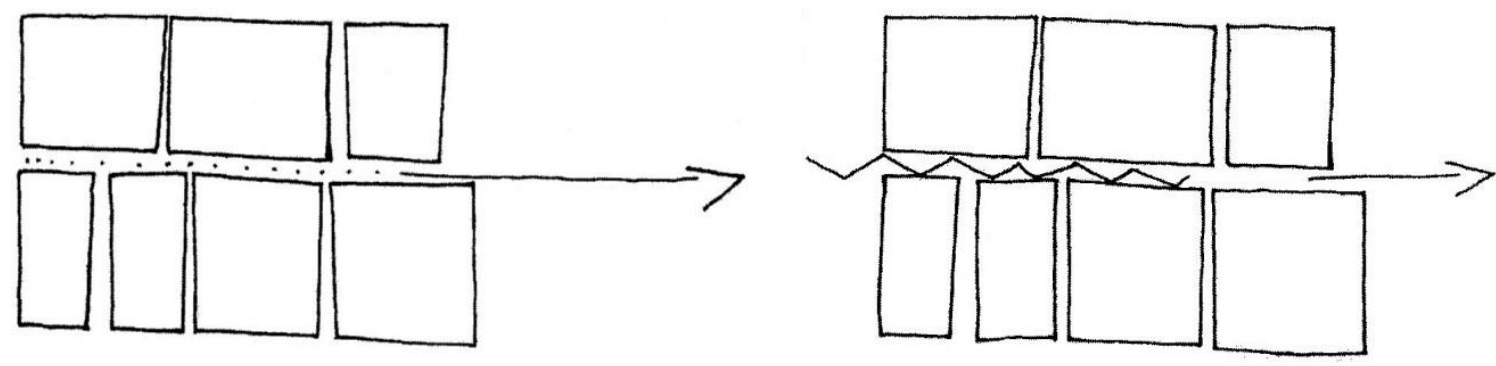

Metódico, mas de um modo diferente do senhor Juarroz, o senhor Calvino "Não gostava de acelerar o passo nem de o abrandar. Quando estava atrasado não acelerava, chegava atrasado" (Ibid., p. 56).

Do mesmo modo, "Quando estava muito adiantado, fazia assim" (Ibid., p. 57).

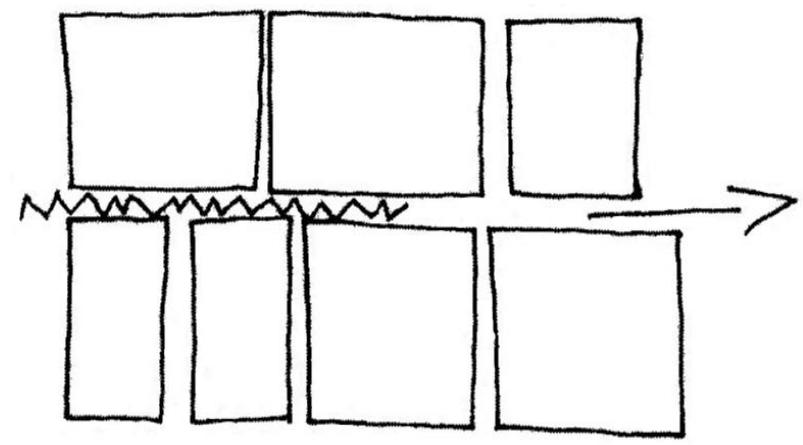

${ }^{41}$ Desenhos desta e da página seguinte de Rachel Caiano. In: TAVARES, Gonçalo M. 0 senhor Calvino. Rio de Janeiro: Casa da Palavra, 2007c, p. 56-57. 
"E quando estava mesmo muito, muito adiantado, fazia assim" (Ibid., p. 57).

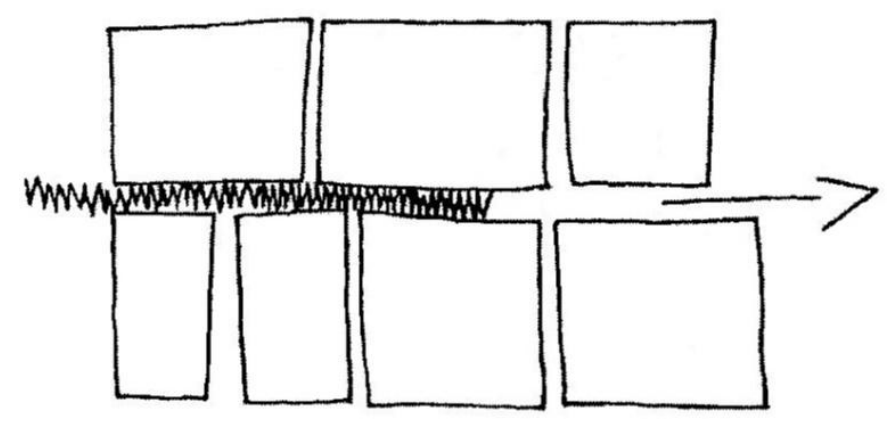

Tanto o senhor Calvino, ao estabelecer modos de andar de acordo com as circunstâncias, como o senhor Juarroz, tentam ambos exercer, de maneiras distintas, controle sobre as coisas. No caso do senhor Juarroz, isto significa estar no comando até mesmo das palavras:

Para mostrar que não se submetia à ditadura das palavras 0 senhor Juarroz todos os dias dava um nome diferente aos objetos. Metade do seu dia de trabalho passava-o assim a atribuir nomes às coisas. Por vezes, ficava tão cansado com essa tarefa inaugural, que passava a segunda parte do dia de trabalho a descansar. Quando adormecia os novos nomes das coisas misturavam-se, nos sonhos, com os antigos nomes, e por vezes o senhor Juarroz acordava tão embaralhado que deixava cair a primeira coisa que tentava segurar, e essa coisa, da qual por momentos não sabia o nome, partia-se (TAVARES, 2007a, p. 21, sublinhado nosso).

Nos dois casos, a busca por marcos referenciais próprios, de aparente livre escolha, resulta no inusitado, no descontrole, os quais, em última instância, ocasionam, paradoxalmente, o contrário da proposta inicial, que é a intenção de "sentir-se no controle". A metáfora do objeto que cai e se parte remete à perda de referências e ao não reconhecimento, tal como o manejo do tempo pelo senhor Calvino que, ao não modificar o ritmo dos passos em caso de atraso, acaba de fato chegando atrasado, fato representativo da perda do 
controle de uma situação que poderia ser, em uma primeira visada, contornável.

Nota-se aqui um jogo dialético que fundamenta as narrativas dos senhores Calvino e Juarroz: controle $X$ liberdade de escolha / surpresa $X$ previsibilidade.

Vale ressaltar que, muitas vezes, o arranjo sintático ordenado dos períodos se coloca em desacordo com a aparente tortuosidade dos pensamentos e das maneiras de ser dessas duas personagens, estabelecendo, portanto, um contraste entre a forma e o conteúdo do texto.

Assim, para exprimir a ideia que tem de si como um homem provinciano, o senhor Calvino expressa seus pensamentos de maneira sintaticamente clara, mas distorcida quanto ao conteúdo do que é expresso, na sua definição/exemplificação de provinciano, característica pessoal, que, para ele, tem duas dimensões. Encerrando o seu raciocínio, ele se lembra, a propósito, de algo que nenhuma relação estabelece com o exposto:

Provinciano no espaço, pensou, é aquele que é influenciado e tenta influenciar os quarenta metros quadrados à sua volta. Provinciano no tempo é aquele que é influenciado pela tarde anterior e pretende influenciar, quando muito, os dois dias seguintes. Lembrou-se, a propósito, daquela personagem descrita pelo escritor $T$., personagem que era tão vesga que às quartas-feiras olhava, ao mesmo tempo, para os dois domingos. E Calvino pensou: isso sim, é um olhar lúcido (TAVARES, 2007c, p. 67, sublinhado nosso).

Os jogos de opostos, as dualidades e as ambiguidades não se dão ao nível da sintaxe propriamente, mas das personagens em relação aos enredos, refletindo suas maneiras deslocadas de ser, próprias de sujeitos que transitam entre extremos, buscando o conforto de um encaixe e de um centramento nem sempre possível, posicionamentos os quais se colocam, o mais das vezes, como horizonte utópico. É o que acontece com o senhor Calvino:

Lembrou-se então de um diálogo absurdo: Estou triste porque tenho o rosto triste. É a única causa? Sim. Mas quê?, o ser 
humano não era assim tão simples. Estar triste não era apenas uma fisionomia oficial (pensava Calvino), era mais do que isso. $\mathrm{Na}$ tarde anterior, por exemplo, Calvino subira a um banco. Onde está? - perguntara o senhor Bettini, o cego que fora visitar. Em cima de um banco - respondera o senhor Calvino. Como quem pergunta as horas, o senhor Bettini perguntou, então, naquela altura, com as suas maneiras bruscas: De onde se encontra, consegue distinguir claramente os Deuses das ovelhas que pastam? Como? - perguntara, estupefato, Calvino. Por que razão se lembrava agora ele disso? Não sabia. A memória não era um simples armazém de coisas antigas de que ele tivesse a chave. Pois bem, sem explicações, avançou. Sentia, de fato, que em certos dias era uma personagem estranha. Via-se como um peregrino, mas não tinha meta nem mapa. Queria ir direto, sem desvios, para um sítio onde se sentisse perdido (Idem, p. 54-55, sublinhado nosso).

O previsto para o senhor Calvino não é o desejável, mas o possível, com algumas surpresas reservadas se ele se permitir a não programação e a metodicidade compulsiva. Sua tristeza é interna, com eventuais reflexos externos, sentimento em que a relação de causalidade inexiste, a não ser na linguagem: "Estou triste porque tenho o rosto triste" (Ibid., p. 54). Ele tem consciência, ou intuição, de que aquilo que ele chama de "apenas uma fisionomia oficial" (p. 55) é, na verdade, muito mais que isso.

Calvino se coloca perplexo e ao mesmo tempo conformado com a complexidade humana, que ele não logra penetrar, e que vai além da memória armazenada e do que ele pode apreender. Incapaz de reconhecer-se, por vezes, tudo o que sabe é que tem de continuar buscando, comparando a si mesmo a um peregrino, o que percorre caminhos para chegar a um certo lugar, ressalvado o fato de que, diferentemente de um peregrino, não possui "meta nem mapa" (p. 55). Trata-se de uma procura "no escuro", que vale por si mesma. O lugar onde ele possa sentir-se perdido equivale, metaforicamente, à perda da consciência de saber-se buscando, sem ter nenhuma certeza de poder encontrar a própria identidade e referenciais de conforto. 
Sob a simplicidade sintagmática do texto se esconde a complexidade semântica do discurso e, mais que isso, a crise e a perplexidade do homem que intui que a sua busca pode ser inútil, o que não o impede de prosseguir.

O caminhar tortuoso que faz o senhor Calvino quando está adiantado, ou muito adiantado, é um caminhar com desvios, sem rumo, um desenho incerto no espaço, porém metódico, como uma forma errática de busca. $O$ desejo de Calvino é a representação da busca utópica, ou seja, o caminhar daquele que não sabe claramente para onde vai ou aonde quer chegar.

Quanto ao senhor Walser, sua procura é aparentemente direta e mapeada, diferentemente da que é feita pelo senhor Calvino. Seu desejo do encontro com a alteridade, que parte do planejamento detalhado para chegar à construção da casa, o deixa certo de que fez tudo o que devia para obter 0 resultado esperado. Também ele almeja o novo, o ideal aguardado e planejado, e os seus atos concretos apontam para a consecução dos objetivos. Não se dá aqui a busca "no escuro" do senhor Calvino, mas, sim, um plano em ação do homem que sabe de onde parte e o que deseja alcançar.

Os aspectos concretos do lugar se mesclam à euforia do senhor Walser, partindo da idealização do projeto, da escolha do lugar, fazendo referência ao papel da tecnologia para levar avante a construção, sem desconsiderar a luta contra a natureza. Isso se reflete no discurso da personagem, romântico e idealizado, quase pueril, como o do senhor Calvino. Todos os elementos se condensam aí em minúcias descritivas, revelando o caminhar em um tempo/espaço longo, tal como o sente subjetivamente a personagem:

Como o senhor Walser está contente! [...] Como se não fosse apenas um movimento físico no espaço - dois passos que se dá - mas também uma deslocação - bem mais intensa no tempo; [...]. Quando fechava a porta atrás de si, Walser sentia virar as costas à inumana bestialidade (de que saíra, é certo, há bilhões de anos atrás, um ser dotado de uma inteligência invulgar - esse construtor solitário que era o Homem) e entrar em cheio nos efeitos que essa ruptura entre a humanidade e a restante natureza provocara; uma casa no meio da floresta, eis 
uma conquista da racionalidade absoluta (TAVARES, 2008, p. 15, sublinhado nosso).

Também aqui se colocam dualidades antagônicas, explícitas e implícitas, que repetem o jogo de opostos:

\author{
homem X natureza \\ espaço urbano $X$ espaço natural \\ solidão X companhia \\ idealizado $X$ realizado \\ racionalidade $X$ bestialidade inumana \\ passado $X$ presente \\ homem primitivo $\mathrm{X}$ homem moderno \\ atraso $\mathrm{X}$ progresso tecnológico
}

Em meio a todas as lutas, o sonhador senhor Walser, que se vê como o grande conquistador de um espaço inóspito, sai aparentemente vitorioso, coroando anos de evolução do homem na terra, cujo percurso, até chegar à sua casa, remonta a uma trajetória muito mais longa e complexa de centenas de gerações antes dele. A visão que a personagem tem de si naquele momento equivale a sentir-se como um elo importante na cadeia da história, tomando parte ativa nela e representando mais um passo no sentido do desenvolvimento humano, tal como o ganhador de uma prova que ousou enfrentar e vencer o desafio proposto pela natureza.

Para Todorov,

A narrativa se constitui na tensão de duas forças. Uma é a mudança, o inexorável curso dos acontecimentos, a interminável narrativa da "vida" (a história), onde cada instante se apresenta pela primeira e última vez. É o caos que a segunda força tenta organizar; ela procura dar-Ihe um sentido, introduzir uma ordem. Essa ordem se traduz pela repetição (ou pela semelhança) dos acontecimentos: o momento presente 
não é original, mas repete ou anuncia instantes passados $\mathrm{e}$ futuros. A narrativa nunca obedece a uma ou a outra força, mas se constitui na tensão das duas, [...] (TODOROV, 2006, p. 21-22, grifo do autor, sublinhado nosso).

A floresta representa a força opositora, que se coloca contra os planos do senhor Walser de ter uma casa junto à natureza - a mesma que insiste em fechar o estreito caminho que leva à propriedade, com o seu crescimento contínuo e aparentemente entrópico. A tentativa da personagem de controlar a mata nativa é representativa dos esforços contrários àqueles empreendidos pela natureza, estabelecendo o jogo dual de forças de que fala Todorov.

As mesmas oposição e tensão ocorrem também, segundo o autor, quanto aos aspectos temáticos:

Os temas da literatura podem ser organizados em duas grandes redes, cujos elementos são, em princípio, incompatíveis. Poder-se-ia definir a primeira como aquela em que predomina a problemática do homem colocado diante do mundo ou, em termos freudianos, o do sistema percepçãoconsciência. Pertence à segunda o tema das relações interhumanas, o que nos remete ao sistema dos impulsos inconscientes (Idem, p. 22, sublinhado nosso).

No caso dos senhores, a questão da incompatibilidade de temas é questionável, já que se pode observar a busca de autoconhecimento por eles empreendida, ao mesmo tempo em que há o movimento em direção ao Outro. Nos dois casos, a força opositora está na diferença de constituição e conformação dos senhores com referência ao padrão do mundo externo, que se coloca como força hostil e contrária em relação aos seus anseios, e que é diferente e peculiar em cada um deles.

Na obra de Gonçalo M. Tavares, as duas redes mencionadas por Todorov estão presentes simultaneamente: há o homem que se coloca perplexo diante do mundo, à procura do Outro, em um ambiente no qual ele se sente deslocado; de outra parte, e ao mesmo tempo, ele se insere em um 
sistema de percepção-consciência, a partir do qual se dá conta do que lhe falta, saindo, então, em busca não somente do Outro, mas da própria identidade.

Em relação à narrativa do senhor Walser, é possível notar ainda que, ao tempo mais lento e descritivo da primeira parte da narrativa, segue-se uma gradativa aceleração temporal, a partir do momento em que, terminada a construção, os profissionais aparecem para executar os consertos. Dada a profusão de especialistas, a quantidade de materiais diversos, ferramentas e áreas de conserto, o senhor Walser chega a perder a noção de si mesmo, indicativa da perda identitária e da proximidade do limiar:

Oscilando entre uma primeira recepção, que tentava manter o mais hospitaleira possível, e a observação do andamento dos vários trabalhos nesse meio-tempo já em curso Walser esquecera-se, de certa maneira, de si próprio (TAVARES, 2008, p. 35, sublinhado nosso).

A partir daí, o nada cerimonioso e ininterrupto entra-e-sai de profissionais gera um aumento na velocidade do suceder dos acontecimentos, diante dos quais Walser não reage, aceitando passivamente, e até justificando, todas as desventuras e intrusões, vítima que é de uma situação absurda, e contra a qual parece impossível lutar, cabendo-Ihe apenas resignar-se:

De fato, parecia-lhe à primeira vista despropositado, sendo um leigo, é certo, o derrube de uma parede por uma questão de má colocação inicial da rede elétrica, mas que sabia ele do assunto?, repetia para si próprio. Um certo incômodo, no entanto, não deixava de se infiltrar em si, pela primeira vez, naquele dia tão importante em que estreava a nova casa. Poderia pelo menos, pensava Walser, ter sido informado. Deitar abaixo uma parede, que raio, tem algum significado (Idem, p. 39, sublinhado nosso).

Assim, enquanto o encanador remove a torneira para consertar o escape de água, Walser reflete em monólogo interior, como se fosse o mero espectador de um filme, inserido à força em uma nova dimensão têmporo- 
espacial. Nesta circunstância, não só o tempo se acelera, mas também se alarga a distância que se interpõe entre as suas reflexões e a realidade circundante, sentindo Walser a nostalgia do que não viveu:

Ansiava, na verdade, pelo momento em que se sentaria de novo, na sua sala nova, usufruindo desse inesquecível cheiro a tinta e a verniz que parece ter um sentido bem determinado, um sentido não material, mas histórico - cheiro que de certa maneira parecia ser a analogia, no mundo físico, da expressão do clássico começo de uma narrativa - o infantil "era uma vez". [...] A distância do seu pensamento ao que se estava a passar era tal que os movimentos do encanador eram vistos como cinema, como se existisse uma película entre os dois, e só um lado, o dele, Walser, fosse verdadeiro (Ibid., p. 27-28, grifo do autor, sublinhado nosso).

No início, ao tomar posse da casa, os discursos de Walser e do narrador onisciente seguem um padrão descritivo minucioso, de períodos longos, sem economia de palavras para falar de detalhes físicos e de estados de alma. A euforia da personagem se reflete nas falas prolixas, em que a memória do passado e as projeções futuras desempenham parte importante para caracterizar a alegria do presente, em um discurso eminentemente marcado por elementos concretos e sensoriais: "Por toda a casa o cheiro a novo! O chão de uma madeira clara, bem polida, atravessa todos os compartimentos, [...]" (Ibid., p. 17).

Mais adiante, ele completa, revelando por meio da concretude dos objetos o prazer físico-sensorial: "E os rodapés, por toda a casa, que perfeitos! Mais: que sentido estético! Que entendimento exato da maneira como cor e forma se devem misturar como se existissem já assim (os rodapés) na natureza, desde o início [...]" (Ibid., p. 21).

Dessa maneira, a prolixidade inicial de Walser caracteriza e confere detalhes ao sonho concretizado, no qual os sentidos desempenham importante papel, avaliando o trabalho realizado dentro do previsto, enaltecendo as qualidades e relevando os defeitos. 
[‥], Walser passeia a mão curiosa pelos ladrilhos da parede. Um ou outro mais para fora e outros (claro) demasiado metidos para dentro, mas no geral todos no mesmo plano. Junto ao chão os pequenos quadrados dos ladrilhos terminam com tranquilidade, sem necessidade de serem amputados nos cantos - tudo aquilo não é apenas mão hábil, é trabalho de cabeça, de previsão, de iniciar algo sabendo onde se vai terminar. Nada de improvisos, um bom trabalho, sem dúvida (Ibid., p. 21, sublinhado nosso).

A alegria de Walser adquire um caráter pueril e inocente, como a recuperação proustiana de uma sensação perdida no tempo. Trata-se de uma descrição mais próxima daquelas do auge do Romantismo, pela riqueza de pormenores que traduzem o estado de espírito da personagem:

Não se poderá acusar pois como excessivo esse movimento de quase dança com que Walser acaricia mobílias, roda manípulos de portas, se senta e levanta das várias cadeiras. Depois, deixa-se afundar no sofá de cor cinza, para dois, imaginando já a sua companheira, a forma como the afastaria os cabelos, como se aproximaria dela. O terreno está conquistado. A sua nova morada[!] (Ibid., p. 21-22, sublinhado nosso).

Entre a felicidade inicial, marcada pela iminência da realização dos sonhos, e a perplexidade incrédula pela ruína dos planos, observa-se uma compressão do discurso, que se retrai em termos atributivos e sintagmáticos:

Mas, subitamente, tocam a campainha. [...]. Antes de se dirigir para a porta, colocou a carta no envelope e fechou-o sem que os seus sentimentos concluíssem algo, tal a rapidez na mudança de estados - entre a solidão entusiasmada e a expectativa provocada pela chegada de alguém. Walser abre a porta da sua casa nova para deixar entrar um homem que chega com todo o aspecto de quem ainda não terminou uma certa tarefa (Ibid., p. 23, sublinhado nosso). 
O desenrolar rápido de eventos, com a chegada sucessiva dos trabalhadores, põe em marcha o desmoronamento do sonho, em que 0 discurso compacto, com diálogos mínimos, acompanhado de gestos, expressões faciais e frases interrompidas revela a aceleração temporal e a disforia da personagem: "No entanto: a campainha. De novo. [...]. Walser abre a porta. É um outro homem, com uma caixa de ferramentas. São as tábuas do soalho. Walser sorriu, acenou com a cabeça, deixou o homem entrar (Ibid., p. $31)$.

E a sequência de intromissões prossegue com a chegada sucessiva do Outro indesejável, que agora comanda o discurso e dá ordens:

Não demorou mais de meia hora até ao terceiro toque na campainha. Era um homem que vinha acertar qualquer coisa na parede [...]. Uma fissura, segundo parece. Logo atrás, outro homem. Walser nem sequer chegou a fechar a porta. Uma janela - não fechava bem. [...]. Walser não via nada de anormal na janela em questão, mas era fácil de ver que este novo homem, além de falador e simpático, era um técnico especializado. [...]. Vou ter que desmontar a janela! exclamou. [...]. [...] mas de novo a campainha obrigou Walser a afastar-se dali (Ibid., p. 33, sublinhado nosso).

Configura-se, assim, o percurso da personagem do cosmos ao caos, da euforia do sonho realizado à disforia da desconstrução do ideal por tanto tempo acalentado:

Ao longo de toda a tarde, vários profissionais foram chegando. [...]. Não é bonito, mas é provisório - alguém disse, tranquilizando Walser. Um pouco mais à frente, dois ou três homens curvados sobre o soalho tentavam ajustar uma série de tábuas que nesse meio-tempo haviam sido levantadas "devido a problemas de infiltração". [...]. Três homens levavam nesse meio-tempo, iá desmontado, partes do sofá cinza - o duplo - para, segundo o que informaram, "repararem as molas" (Ibid., p. 35-36, grifo do autor, sublinhado nosso). 
O mundo, que parecia até certo momento perfeito para Walser, agora se apresenta como um ambiente agressivo, por suas características de intrusiva objetividade e, portanto, incapaz de lhe prover o esperado acolhimento.

A lista de problemas da casa é denotativa da hostilidade que toma conta do lugar, em que as partes se sobrepõem ao todo, sinalizando a desconstrução: a torneira da casa de banho (p. 23); a chave-inglesa (p. 27); a porca que fixava a torneira ao tubo (p. 27); a parafina líquida (p. 27); a mala retangular de trabalho (p. 27); o encanador (p. 28); canos (p. 28); ferramentas (p. 31); tábuas do soalho (p. 31); as fissuras na parede (p. 33); a janela que não fecha bem (p. 33); a rede elétrica (p. 36).

Para todos os senhores, em instâncias diferentes, surge a consciência da hostilidade do mundo em um ou mais aspectos das suas vidas. A fala do senhor Valéry, em certo momento, é indicativa dessa sensação de desamparo, partilhada igualmente, além do senhor Walser, por outros senhores:

O que eu gostava era de ver uma corrida de 100 metros onde cada pista terminasse num ponto diferente. [...] ... deste modo [...] - ao terminar a competição, cada atleta perceberia melhor o que estava à sua espera no dia seguinte. Mesmo que ganhasse acabava a corrida sozinho, [...]. E depois desta afirmação algo ambígua, o senhor Valéry prosseguiu o seu passeio diário, com o corpo um pouco curvado, o chapéu enterrado na cabeca, e sozinho, completamente sozinho, como sempre (TAVARES, 2004a, p. 61-62, sublinhado nosso).

Os mundos interno e externo de cada um dos senhores funcionam em oposição ao que almejam. A entrevista do senhor Breton, por exemplo, com a outra parte de sua persona, revela mais divergências do que propriamente aproximações entre as duas partes, já que uma se sobrepõe à outra na ânsia de obter respostas, marcando uma fragmentação interna irremediável.

Ao formular teorias, que nada mais são que tentativas ordenatórias de concretização e harmonização do mundo, os senhores tentam acercar-se do que para eles é complexo ou distante, simplificando e reduzindo tudo ao essencial. 
A narrativa tavariana, por suas características, quebra outro paradigma dos estudos literários, que é o fato, segundo Todorov (2006, p. 45), de que "A exposição de uma narrativa não se encontra forçosamente no começo, nem o desenlace no fim."

A razão disso se assenta sobre o fato de que o tempo em Os Senhores não é um tempo linear, cronológico, do ponto de vista da sucessão dos eventos, mas essencialmente subjetivo e psicológico, situando-se numa espécie de atemporalidade narrativa, especialmente nas situações de crise, em que se tem o que se poderia denominar de "um tempo em suspenso".

Todos os senhores participam de narrativas curtas, estanques, como em uma colagem de eventos, os quais, às vezes, não têm relação entre si. Nos eventos de que os senhores participam, eles pensam consigo mesmos, reagem a fatos, tecem teorias, divagam, são vistos pelo Outro e veem o Outro, fazem suposições, agem na rua ou em espaços privados, interagindo com a alteridade nem sempre de modo adequado, segundo o ponto de vista formal. Tudo isso em uma dimensão têmporo-espacial que pode, às vezes, se constituir como sequencial e localizada, mas que, em outras ocasiões, prescinde de um tempo/espaço determinado.

De todo modo, há que se tomar sempre a linguagem como ponto de partida e de chegada de qualquer análise, em todos os níveis. Ainda para Todorov,

[...] (a literatura) fornece tanto sua configuração abstrata quanto sua matéria perceptível, é ao mesmo tempo mediadora e mediatizada. A literatura se revela portanto não só como o primeiro campo que se pode estudar a partir da linguagem, mas também como o primeiro cujo conhecimento possa lançar uma nova luz sobre as propriedades da própria linguagem (TODOROV, 2006, p. 54, sublinhado nosso).

De todos os aspectos que podem ser analisados a partir de uma dada obra, talvez o sentido, ou os múltiplos sentidos, sejam os mais complexos, por envolver não apenas o estudo de trechos ou sequências narrativas, mas da 
obra como um todo, em que a fragmentação não pode ser senão um recurso coadjuvante à análise. De acordo com o autor,

Isolar o sentido no conjunto das significações é um procedimento que poderia ajudar enormemente no trabalho da descrição, em estudos literários. No discurso literário, como no discurso cotidiano, o sentido pode ser isolado de um conjunto de outros sentidos aos quais se poderia dar o nome de interpretacõos. Entretanto, o problema do sentido é aqui mais complexo: enquanto, na palavra, a integração das unidades não ultrapassa o nível da frase, em literatura, as frases se integram de novo em enunciados, e os enunciados, por sua vez, em unidades de dimensões maiores, até a obra inteira (Idem, p. 59, sublinhado nosso).

No caso de Os Senhores, numerosos fatores entram em jogo quando se pensa na interpretação da obra, especialmente em se tratando da variedade de cronotopos como determinantes das ações, das características próprias de cada personagem, além das questões diegéticas, que não limitam, mas, pelo contrário, ampliam o campo interpretativo.

Como determinantes do enredo e das ações das personagens, os cronotopos não estão ligados exclusivamente ao tempo cronológico e ao espaço físico, podendo estender-se ao tempo psicológico e a espacialidades indefinidas. Um desses casos se refere ao próprio cronotopo do limiar ou da "soleira", em que a crise pode ou não ocorrer em um tempo/espaço concreto e cronologicamente localizado.

É de se observar a proximidade ideológica da menipeia, o gênero universal das últimas questões com o limiar, conforme mencionado por Bakhtin. Segundo o autor, o limiar em Dostoiévski,

[...] se aproxima do mistério, pois este nada mais é que uma variante dramática medieval modificada da menipeia. Em Dostoiévski, os participantes da ação se encontram no limiar (no limiar da vida e da morte, da mentira e da verdade, da razão e da loucura). Vale dizer que, neste caso, a ação não ocorre apenas "aqui" e "agora" mas em todo o mundo e na 
eternidade: na terra, no inferno e no céu (BAKHTIN, 2005, p. 147, grifo do autor, sublinhado nosso).

Por conseguinte, as ações do enredo são cronotopicamente determinadas, isto é, as relações têmporo-espaciais articulam coordenadamente o desenvolvimento das tramas e o fazer das personagens, como se pode observar nesta narrativa em $\mathrm{O}$ senhor Brecht, "O delito mais grave":

Todo o cidadão que não soubesse respeitar as hierarquias militares era condenado a seis anos de prisão. E todo cidadão que assassinasse outro era condenado a vinte anos de prisão. $O$ assassino, ao ver que o general assistira ao seu crime, jogou tudo por tudo e disse: você é um reles soldado! Resultou. Como os juízes castigavam sempre o delito mais grave, o homem foi condenado a seis anos de prisão (TAVARES, 2005, p. 60).

Percebe-se aí o jogo de palavras que inverte a situação esperada, modificando o modo de resolução da trama, segundo o qual as pessoas têm pouca ou nenhuma importância diante das manobras escusas da lei.

Prosseguindo em suas considerações sobre a importância da interpretação semântica, Todorov afirma que:

O sentido de um monólogo ou de uma descrição deixa-se apreender e verificar por suas relações com outros elementos da obra: ele pode ser a caracterização de uma personagem, a preparacão de uma transformação na intriga, um atraso. Em compensação, as interpretações de cada unidade são inúmeras, pois dependem do sistema no qual ela será incluída para ser compreendida. Segundo o tipo de discurso no qual se projeta o elemento da obra, teremos uma crítica sociológica, psicanalítica ou filosófica. Mas será sempre uma interpretação da literatura num outro tipo de discurso, enquanto a busca do sentido não nos conduz ao exterior do próprio discurso literário (TODOROV, 2006, p. 59, sublinhado nosso). 
Outro aspecto importante a influir sobre a análise de uma obra é a questão dos tempos verbais, objeto de estudos de Émile Benveniste. Nesses estudos, o autor mostrou, conforme mencionado por Todorov (Idem, p. 59), existirem "[...] dois planos distintos de enunciação: o do discurso e o da história. Esses planos de enunciação se referem à integração do sujeito de enunciação no enunciado", sabendo-se que toda língua apresenta um número determinado de elementos que informam ao leitor sobre o ato e o sujeito da enunciação, operando a conversão da linguagem em discurso. Os demais elementos se destinam apenas a apresentar os fatos daí decorrentes. Ainda de acordo com Todorov,

\begin{abstract}
A dosagem dos dois planos de enunciação determina o grau de opacidade da linguagem literária: todo enunciado que pertence ao discurso tem uma autonomia superior, pois toma toda sua significação a partir de si mesmo, sem o intermediário de uma referência imaginária (Idem, p. 60, sublinhado nosso).
\end{abstract}

Tal pode ser apreciado em 0 senhor Walser, narrativa em que, ao tomar posse da casa, a personagem desfruta de uma alegria quase infantil, surpreendendo-se com a quantidade de cômodos:

[...] os compartimentos, que são muitos, diga-se, tantos que Walser não é capaz de os contar; um excesso, sem dúvida, mas como criticar alguém que se entusiasma tanto com as suas próprias expectativas, que aproveita $\circ$ terreno que ninguém quer para construir na maior extensão possível? Quem sabe o que vem aí, pensou Walser nos momentos em que projetou mais compartimentos; quem pode adivinhar o que acontece a uma existência? De fato, não construíra aquela casa para o homem solitário que era naquele momento. Sejamos claros, sem entrar em pormenores: Walser tinha grandes expectativas (TAVARES, 2008, p. 17, sublinhado nosso).

No trecho acima, misturam-se as vozes do narrador onisciente e opinativo e a voz do senhor Walser, em monólogo interior. O início é marcado 
pelo discurso do narrador onisciente, que termina na pergunta: "[...] como criticar alguém que se entusiasma tanto com as suas próprias expectativas, que aproveita o terreno que ninguém quer para construir na maior extensão possível[?]" (Idem, p. 17).

A partir daí, entra o monólogo interior, marcado pela mudança no tempo verbal. O que o narrador declara, ainda que de forma exclamativa, equivale a um comentário valorativo que se dá no presente. O momento em que se inicia o monólogo interior da personagem, no período que vem em sequência à pergunta, corresponde à tradução das "grandes expectativas" do senhor Walser: possuir uma casa maior, encontrar uma companheira, constituir família.

Às indagações sobre o futuro - "Quem sabe o que vem aí, pensou Walser nos momentos em que projetou mais compartimentos; quem pode adivinhar o que acontece a uma existência[?]" (Ibid., p. 17) - fica implícita a resposta de que o senhor Walser pretende ter filhos, uma família grande, por isso necessita de uma casa espaçosa, em oposição à condição atual de homem sozinho. No final, volta a falar o narrador onisciente, reforçando a ideia esperançosa da personagem quanto ao futuro.

O que Todorov e Benveniste denominam história, isto é, o enredo, ou a trama, resume-se apenas ao trecho em que o leitor fica sabendo que a casa de Walser é grande. Todas as demais afirmações não constituem história, segundo os autores, mas discurso, tanto da parte do narrador onisciente e opinativo, como do senhor Walser em monólogo interior.

Ainda segundo Todorov (2006, p. 61, grifo do autor), os formalistas russos já haviam percebido a oposição entre discurso e história, embora não pudessem demonstrar as bases linguísticas de tal fato: "Em toda narrativa, eles distinguiam a fábula, isto é, a série de acontecimentos representados, tais quais eles se teriam desenrolado na vida, da trama, arranjo particular dado a esses acontecimentos pelo autor".

Para esse autor, tal oposição não constitui uma dicotomia entre a obra e a vida representada, mas evidencia a dupla natureza de enunciado e enunciação. Para o teórico, "Esses dois aspectos dão vida a duas realidades, 
tão linguística uma quanto outra: a das personagens e a da dupla narradorleitor" (Idem, p. 61).

Nas narrativas tavarianas em questão, a visão peculiar das personagens em relação a si mesmas e ao mundo não se pode confundir com a visão do narrador opinativo e onisciente, que descreve a ação de determinada personagem, nem com as possíveis interpretações posteriores acerca dessa mesma ação, quando feitas pelo leitor. Também a função-autor, ao transformar fábula em trama, responde por decisões quanto às maneiras pelas quais isso se vai realizar, não se misturando, igualmente, às possíveis interpretações que farão o leitor e o analista a partir do que é exposto.

Também a visão interpretativa do leitor pode induzi-lo a estabelecer outras relações e identificações, que podem estar para além do que é narrado, como no caso da obra de Gonçalo M. Tavares, em que é possível conectar elementos da vida dos senhores a aspectos da contemporaneidade, sem prejuízo do que a obra tem a oferecer, por si mesma, enquanto constructo artístico.

Outro aspecto significativo das narrativas sob análise diz respeito ao uso recorrente de uma linguagem emocional por parte dos senhores, especialmente quando se trata da relação homem-mulher. Tal pode ser apreciado quanto às personagens principais em 0 senhor Walser e em 0 senhor Calvino em várias instâncias, já que ambos são homens essencialmente sensíveis e românticos.

Nessa instância, tanto o discurso do narrador onisciente, como o da própria personagem revelam, por meio de metáforas e da escolha de vocábulos, uma delicadeza de formas e intenções, ao se referir Walser a um possível relacionamento conjugal futuro, ou à casa, que, em certos momentos, figurativiza o próprio relacionamento com o Outro, como uma concretização antecipada, indicial e simbólica, do que está por vir, seja do ponto de vista de um futuro casamento, ou da convivência com amigos. Assim,

A casa não era para Walser apenas um lugar que a humanidade conquistara à floresta, ao espaço que as coisas não humanas pareciam ter determinado como seu - era ainda 
uma paisagem ideal para começar a falar com outros homens [...]. (TAVARES, 2008, p. 11-12, sublinhado nosso).

À semelhança de um escritor romântico do século XIX - na postura, no idealismo e na linguagem -, deslocado para a contemporaneidade, o senhor Walser opõe características de um tempo passado à evolução da época atual. Em certa ocasião, ao convidar, por carta, Thereza M. para visitá-lo, ele o faz "[...] com os mais recatados termos, [...]. Cada palavra no seu sítio, cada letra como se da sua forma dependesse a própria estrutura da casa, [...]" (Idem, p. 22, grifo do autor, sublinhado nosso).

Em outro momento, agora como um cavaleiro medieval deslocado no tempo, Walser defende desta vez outra donzela, a estrada, contra a qual a natureza, também personificada como alguém dotado de vontade própria, faz suas investidas, inimigo real e incansável que precisa a todo custo ser derrotado. Sua arma não é uma lança, mas um machado, "de dimensões significativas" (p. 14). Defendendo a estrada como a uma dama indefesa, o senhor Walser resguarda, romanticamente, um possível futuro relacionamento, de modo a esperar "um beijo apaixonado, o encontrar de uma companhia definitiva" (Ibid., p. 14).

É possível notar que o senhor Walser, em dada circunstância, em um arroubo de vaidade, manifestado em monólogo interior, se coloca metonimicamente como se fosse, ele próprio, a representação da humanidade evoluída, metáfora do progresso da civilização, que chega agora à sua culminância: "[...] ([...] - esse construtor solitário que era o Homem) e entrar em cheio nos efeitos que essa ruptura entre a humanidade e a restante natureza provocara; [...]" (Ibid., p. 15).

O fracasso do sonho de Walser emerge a partir da sua submissão ao domínio intrusivo dos especialistas, que the invadem a casa e acabam por determinar "o quê", o "como", o "quando", o "onde" e o "quanto", referentes aos consertos. A comparação ao final da citação é a marca da ironia do tratamento dispensado ao dono da casa pelos trabalhadores, quando um deles sorri em retribuição à hospitalidade de Walser, revelando sua superioridade técnica 
frente à tímida aceitação do outro: "Um crente face a um ateu não sorriria de forma mais satisfeita (Ibid., p. 37, sublinhado nosso).

Dessa forma, o quest enfrentado pelo senhor Walser, é menos uma saga de desventuras e conquistas, e mais um roteiro unicamente de provações e penas a que a personagem é submetida, de modo semelhante ao que ocorre no cronotopo do romance grego clássico. O sonho inicial de Walser - de ter uma casa em um ambiente bucólico, de desfrutar da companhia de uma mulher, amigos, enfim, de partilhar sua vida em um recanto agradável, rodeado por pessoas de sua estima, não se modifica ao longo da narrativa.

Aquilo que se interpõe, contudo, entre os seus planos iniciais e a sua concretização, está configurado na invasão dos profissionais, os quais assumem a voz e o status da autoridade. Ao Ihe desmontarem a casa, destroem também, temporária e indefinidamente, a consecução do seu projeto de vida, criando, nessa instância, a ruptura e o hiato extratemporal de que fala o teórico russo (BAKHTIN, 1988, p. 216), pelo evento inesperado, que interrompe o fluxo normal da vida e separa a felicidade da desventura.

Personagens em devir, os senhores carregam em si peculiaridades e idiossincrasias que não os definem claramente como A ou B. São na verdade $A$ e $B$, e muitas coisas mais. Equilibram-se como que sobre lâminas, as quais representam embates, anseios, dúvidas, buscas, indagações, não se constituindo as personagens como indivíduos portadores de respostas acabadas e conclusivas, emulando a condição do homem da contemporaneidade.

Em O senhor Calvino, a linguagem e o conteúdo do que diz a personagem revela sua maneira peculiar de ser, sua visão da vida e do Outro. Ao falar de sua obsessão por métodos, ele resvala para a circularidade e a tautologia:

Interesso-me de muitas maneiras pela mesma coisa. [...]. Interesso-me da mesma maneira por muitas coisas. [...] Interesso-me ao mesmo tempo de muitas maneiras por muitas coisas. Hoje, ao acordar, preguiçoso: Não me interesso por nada, porém faço tal coisa de muitas maneiras diferentes (TAVARES, 2007c, p. 37, sublinhado nosso). 
Segue-se uma enumeração, à maneira de Rabelais, em que o senhor Calvino detalha, em pormenor, o que não faz "de muitas maneiras diferentes":

Não lia, não escrevia, não pensava, não contava histórias, não executava mentalmente combinações entre coisas do mundo: sentava-se, olhava para os sapatos, coçava a cabeça, deitavase no sofá - todo enrolado primeiro, depois esticado, a cabeça para um lado, depois para o outro, a barriga para cima, depois para baixo -, levantava-se, dirigia-se à cozinha, bebia um copo de áqua, olhava pela janela, observava o clima, abria a janela, punha a mão lá fora, testava a quantidade de frio, sentia o vento, fechava a janela, endireitava a chave de uma gaveta, desapertava um botão da sua camisa, voltava à sala, $e$ sentava-se então de novo no sofá decidido a experimentar uma inédita sonolência (Idem, p. 37-38, sublinhado nosso).

Há no entrecho, toda uma sequência verbal de ações denotativas do tédio que sente o senhor Calvino, quebrada, de súbito, pela última: "[...] e sentava-se então de novo no sofá decidido a experimentar uma inédita sonolência", que opõe, semanticamente, as palavras inédita e sonolência, contrariando a ideia da monotonia nada incomum sentida pela personagem, a qual vem a ser completada por um prosaico cochilo.

Todos os senhores, em diferentes medidas e aspectos, têm o perfil do homem solitário, o qual aparece na Idade Média no romance europeu. É o caso do senhor Walser, cuja vida se passa "do lado de fora", especialmente depois da chegada dos profissionais.

Os mais introvertidos, como os senhores Juarroz, Brecht, Kraus, Breton e Walser vivem com reservas, cultivando uma vida interior apartada de movimentos externos acentuados, de modo semelhante ao homem medieval, que perdeu seu aspecto público, sofrendo, por isso, a consequente deformação da imagem original do homem clássico, exteriorizado, coeso e homogêneo, que é assim descrita por Bakhtin:

Nas épocas posteriores, as esferas mudas e invisíveis das quais o homem tornou-se participante, deformaram-lhe a 
imagem. O mutismo e a cegueira penetraram em seu íntimo. Juntamente com isso chegou a solidão. O homem privado $\mathrm{e}$ isolado, "o homem para si", perdeu a unidade e a integridade que eram determinadas pelo princípio da sua vida pública. A consciência que ele tem de si mesmo, tendo perdido 0 cronotopo popular da praça pública, não pôde encontrar outro cronotopo tão real, único e íntegro (BAKHTIN, 1988, p. 254, grifo do autor, sublinhado nosso).

Segundo o filósofo da linguagem, Mikhail Bakhtin (Idem, p. 254), as esferas íntimas do homem, que se torna privado a partir de certo momento, como as de natureza sexual e outras equivalentes, só podiam aparecer em termos condicionais e entre as quatro paredes da alcova, ocorrendo aqui a cisão definitiva do núcleo interior e exterior desse homem.

Ao narrar sobre os senhores, Gonçalo M. Tavares fala do homem contemporâneo, solitário, em estado de crise, muitas vezes no limiar, necessitando estabelecer relações próximas com a alteridade, que não necessariamente mediadas por meios eletrônicos e indiretos. Por outro lado, esse homem também se torna público à medida que perde a sua privacidade, mazela que aflige a contemporaneidade, representada pelas intrusões do Estado e das instituições, das redes sociais, da mídia, e do sistema de um modo geral.

Quanto ao senhor Walser, evidencia-se o rompimento desse núcleo, e ao surgimento do desejo de retorno a uma vida idílica, romântica e primitiva, marcada pelo distanciamento em relação aos prédios que constituem $\mathrm{O}$ Bairro, cuja vida urbana e verticalizada não supre as necessidades de alguém que deseja a combinação de natureza e privacidade em torno de si.

Este senhor, tal qual o homem da pós-modernidade, que deveria ter a tecnologia ao seu serviço, se vê, por razões não explicadas, como uma vítima do progresso, o qual, em vez de lhe facilitar a vida, o subjuga. Do mesmo modo, ele é também presa da superespecialização contemporânea, que dirige os profissionais apenas para o foco específico de conhecimento da sua área, pago com o preço da perda da visão do todo. 
Assim, fragmentam-se a casa, o sonho e o homem, deste último sendo tirados todos os referenciais de segurança, tal como ocorre com os personagens subjugados das narrativas em 0 senhor Brecht.

Em uma delas, "O naufrágio", expõem-se as tendências características do sadismo, da violência e da morbidez, presentes nas inusitadas histórias narradas por aquele senhor.

Assim, após um naufrágio, apenas um hipopótamo e o seu dono conseguem escapar a bordo de um pequeno bote. Uma vez que o hipopótamo representa o ganha-pão do proprietário, e ao desequilibrar-se perigosamente o bote para um lado, temeroso de que seu animal se afogasse, "o homem cortou um pedaço do hipopótamo e comeu-o, o que também era oportuno, pois começava a estar com fome" (TAVARES, 2005, p. 24).

Emerge aí o individualismo do dono do animal, que come partes dele, aos poucos, para sobreviver, em uma circunstância absurda, já que o hipopótamo, animal aquático, não precisaria estar no bote. $O$ desequilíbrio do barco, causado pelo peso do animal, figurativiza o próprio desequilíbrio humano, reflexo da sociedade atual, em que não há espaço para a solidariedade ou a compaixão. Ao adernar novamente o bote, prossegue 0 narrador:

O homem decidiu então comer mais um pedaço do hipopótamo. Depois de o fazer, olhou para o barco e viu que ainda não era suficiente: tirou mais um bom bocado do animal e comeu-o. O barco recuperou o equilíbrio. A viagem durou ainda algumas semanas e o homem, de seis em seis horas, via-se obrigado a cortar mais um bocado do animal (Idem, p. 24-25, sublinhado nosso).

A palavra equilíbrio é ironicamente empregada aí, bem como o trecho "A viagem durou ainda algumas semanas e o homem, de seis em seis horas, via-se obrigado a cortar mais um bocado do animal" (Ibid., p. 24, grifo nosso). A história remete também à oposição homem e natureza, revelando-se 0 primeiro como um predador racional e oportunista. 
Em todas as histórias do senhor Brecht, a relação Eu-Outro se coloca como uma improbabilidade, uma vez que não há espaço para a aproximação, a familiaridade, a compaixão ou a cumplicidade. Não há atos de afeto ou acolhimento, apenas o inexorável e o cruel irreversíveis.

A ideia de que não há saída para as personagens, cujas imagens são geralmente de sofrimento e aceitação compulsórios, aparece figurativizada na narrativa "Cedo demais": "A guerra começou ainda os mapas não estavam prontos. Por inadvertência, o exército inteiro - com os seus milhares de soldados, os seus canhões e tanques - entrou numa rua sem saída" (Ibid., p. $39)$.

Mais uma vez fica aí estabelecido o nonsense, segundo o qual, exércitos com canhões e tanques não dispõem do óbvio, isto é, mapas. A rua sem saída metaforiza a situação do limiar, o extremo para o qual não há opção ou solução possível. Trata-se do impasse, do imponderável e do absurdo, condições que não admitem alternativas plausíveis. A falta de mapas sinaliza igualmente a condição do homem da contemporaneidade, sem balizamentos ou orientação segura quanto ao caminho a seguir.

Em sentido oposto à crueldade e ao desequilíbrio das narrativas do senhor Brecht, posiciona-se o romântico e ingênuo senhor Calvino, cuja sensibilidade emerge em uma carta que ele escreve à amiga Anna (TAVARES, 2007c, p. 41).

Nela, uma descrição à primeira vista romântica, vazada em um linguajar aparentemente rebuscado e formal, se coloca em discordância com o conteúdo erótico, ao contemplar o mesmo senhor os campos prontos para a colheita e os casais fazendo amor, escondidos pelas plantações de trigo.

A diferença entre a linguagem deste senhor e a do senhor Walser é de que se trata aqui de um conteúdo mais sensual e direto, suavizado pela escolha dos vocábulos, de natureza poética, e pelas construções frasais, em que predominam as inversões. Não há gemidos, mas uivos, não existem casais em intercurso amoroso, mas movimentos sexuais, aproximando do animalesco o que se supunha romântico de início. 
Excelentíssima Anna. Por aqui os campos, com os seus cereais robustos, continuam a tapar melhor os movimentos sexuais do que os uivos que daí resultam. Trata-se pois de uma discordância evidente entre som e sua origem. E sendo o prazer um excesso acima do táctil, é de salientar no entanto a elevação agitada do som que se torna na atmosfera o ator principal, atirando assim - por via do vento - um rubor forte à cara das aldeãs que da janela pensavam ver, mas afinal ouvem. Devido aos campos férteis que funcionam como cortina, nesses instantes, onde casais jovens se excitam como instrumentos afinados, para um surdo, cara Anna, a janela torna-se subitamente inútil (Idem, p. 41, sublinhado nosso).

Movido possivelmente pelo desejo romântico e ao mesmo tempo sensual, de estar ele próprio, Calvino, ali, no meio de um trigal a possuir a sua amada, e não podendo ser o ator naquela cena, contenta-se em ser o relator, para Anna, do que não sendo visto, pode ainda ser ouvido. Os ruídos do amor, sons inacessíveis para a personagem, enquanto realidade vivida, chegam até ele como para as aldeãs ruborizadas, apoiadas à janela. Apenas sons, os quais, para um surdo, não significariam nada, também para ele, Calvino, são apenas uma descrição distanciada, um espreitar velado de uma cena à qual não pertence.

As primeiras narrativas de cada livro, em Os Senhores, refletem, de modo geral, situações até certo ponto agradáveis. No decorrer das histórias, todavia, aos poucos assomam os sujeitos e as situações do limiar, o desconforto, a sensação de deslocamento em relação ao entorno, acompanhando a conscientização que Ihes chega, aos poucos, de que a crise os cerca por todos os lados.

Na verdade, tal crise não é apenas de natureza intrínseca, causada por suas particularidades, obsessões e idiossincrasias. A pouco e pouco, todos os senhores vão se dando conta de que o mal-estar interno vai além do Eu e das circunstâncias imediatas. 
Quanto ao senhor Kraus, que denuncia os secretos e espúrios bastidores da vida política, há uma luta interna contraditória de quem sabe que é necessário tornar públicos os desmandos governamentais, mas, ao mesmo tempo, tem consciência do limitado alcance de suas boas intenções.

O tempo/espaço recôndito da vida política, materializado no gabinete do Chefe, e representativo do cronotopo da sala de visitas, é o lugar e o tempo onde se encontram os políticos e os seus assessores, autossupridos e mantido, nos diversos níveis e cargos, sob o pressuposto óbvio de que todos ali querem manter os seus postos, o poder e o status quo, não importando o preço a pagar.

Nesse sentido, é possível observar a importância do cronotopo para a construção da imagem das personagens, de suas falas e ações, graças à manutenção de uma circularidade retroalimentadora: constituída, no caso do Chefe, por falsos elogios e vaidades, nenhuma visão da realidade tal qual ela é, o cronotopo da sala de visitas da vida política se organiza independentemente da vida da população, o que leva a uma absoluta distorção do papel que os políticos e os seus assessores deveriam, em tese, desempenhar.

Ao povo, por sua vez, só resta suportar, a contragosto, seus governantes, com a certeza implícita de que, se estes saírem, outros da mesma estirpe virão ocupar o seu lugar, numa espécie de jugo permanente do destino. Tal fato leva o senhor Kraus, tomado por um sentimento de impotência, a concluir "O fim do dia avançava como ontem e, no mundo, em breve, apareceria outro Chefe, depois outro, e outro. Sempre o mesmo, portanto" (TAVARES, 2007b, p. 114).

Personagens e situações que parodiam a realidade contemporânea, as narrativas dos senhores buscam expor os desconfortos e mazelas que assolam a vida do homem da pós-modernidade.

A paródia como gênero cumpre, assim, o papel de, segundo Linda Hutcheon (1985, p. 27, grifo da autora), proceder a uma "transcontextualização" e à inversão como formas parodísticas complementares, que vão além da citação. No caso das matérias do senhor Kraus, há tanto o uso da paródia 
como da sátira, sendo esta última o recurso mais frequente de que faz uso o jornalista para expor os bastidores escusos do poder instituído.

A autora estabelece, ainda, a diferença entre sátira e paródia, afirmando que a primeira "[...] é simultaneamente moral e social no seu alcance e aperfeiçoadora na sua intenção. Não quer dizer isto, [...], que a paródia pode, evidentemente, ser utilizada para satirizar a recepção ou até a criação de certos tipos de arte" (Idem, p. 28).

Segundo Ronald Paulson,

[...] a razão óbvia para a confusão de paródia e sátira, apesar desta diferença essencial entre elas, é o fato de os dois gêneros serem muitas vezes utilizados conjuntamente. A sátira usa, frequentes vezes, formas de arte paródicas, quer para fins expositórios, quer para fins agressivos, quando aspira à diferenciação textual como veículo (PAULSON, 1967 apud HUTCHEON, 1985, p. 62, sublinhado nosso).

Ainda de acordo com Hutcheon, vários estudiosos da paródia são da opinião de que esta "[...] prospera em períodos de sofisticação cultural que permitem aos parodistas confiar na competência do leitor (espectador, ouvinte) da paródia" (HUTCHEON, 1985, p. 31).

Ela observa certa reserva de Bakhtin quanto ao uso da paródia moderna, o que a faz estabelecer uma analogia com o processo de carnavalização tal qual é visto pelo autor russo. De modo a neutralizar, em certa medida, a visão um tanto reducionista em relação à paródia por parte do teórico, Linda Hutcheon contrapõe o fato de que

[...] apesar das limitações da opinião de Bakhtin sobre a paródia moderna, muitas das suas observações teóricas sobre o carnaval primitivo são surpreendentemente adequadas e esclarecedoras em relação à situação estética e social contemporânea. Existem, talvez, razões históricas para esta rápida adaptabilidade. A metaficção contemporânea, [...], existe - tal como o carnaval - nessa fronteira entre a literatura e a vida, negando enquadramentos e ribaltas. [...]. Tanto a sua 
forma como o seu conteúdo podem operar subvertendo as estruturas autoritárias lógicas, formalistas. A abertura ambivalente da ficção contemporânea talvez sugira também que os mundos medieval e moderno podem não ser tão fundamentalmente diferentes como gostaríamos de pensar [...] (Idem, p. 94, sublinhado nosso).

De modo diferente, as narrativas do senhor Brecht possuem igualmente um viés crítico às instituições de poder, ao colocar o leitor diante de temas ligados ao que se poderia chamar de fantástico-alegórico, isto é, os acontecimentos descritos não pertencem à realidade tal como a vivenciamos, e não oferecem ao leitor nenhuma explicação, mas os conteúdos e as personagens remetem, alegoricamente, a fatos, pessoas e situações que pertencem à realidade do mundo social, especialmente à do homem da "modernidade tardia", que é assim caracterizada por Anthony Giddens:

As instituições modernas diferem de todas as formas anteriores de ordem social quanto a seu dinamismo, ao grau em que interferem com hábitos e costumes tradicionais, e a seu impacto global. No entanto, essas não são apenas transformações em extensão: a modernidade altera radicalmente a natureza da vida social cotidiana e afeta os aspectos mais pessoais de nossa existência. A modernidade deve ser entendida num nível institucional; mas as transformações introduzidas pelas instituições modernas se entrelaçam de maneira direta com a vida individual, e, portanto, com o eu (GIDDENS, 2002, p. 9, sublinhado nosso).

A distinção essencial entre os políticos satirizados nas crônicas do senhor Kraus e o próprio jornalista é de ordem axiológica. A questão ética inexiste para o Chefe e os seus Auxiliares. A voz das altas esferas políticas é rasurada pela incompetência de um político incapaz de diferenciar um mapa de um lenço. Ao povo, sem voz, cabe fugir dos políticos, já que o embate parece inútil. 
A linguagem analógica e paródica usada pelo jornalista faz o Chefe denominar de "os Outros" o povo que o elegeu, rebaixando-os à condição de "Necessários" (TAVARES, 2007b, p. 18).

Movimento para o Chefe, não são as providências a tomar para levar adiante esta ou aquela benfeitoria, mas apenas uma "dança de cadeiras" literal, em que o Chefe ordena que os Auxiliares troquem de lugar e batam com os pés no chão ininterruptamente:

Permanecendo sentados, os dois Auxiliares estavam há vários dias a bater com os pés no chão. A sola dos sapatos parecia lentamente desaparecer e, por dentro das meias, cujo tecido praticamente evaporara, os pés ardiam, como próximos de uma lareira. Um e outro tinham já várias feridas nos pés. No entanto, o sorriso aberto na cara dos dois Auxiliares jamais afrouxara. Era preciso movimento, movimento! - dissera o Chefe. Até as eleições (Idem, p. 26, sublinhado nosso).

Ao ordenar a mudança de lugar dos Auxiliares, de uma cadeira para outra, revela-se o linguajar pernóstico e cerimonioso dos políticos quando dialogam entre si, pontuado por inócuos, ainda que solenes, pronomes de tratamento:

O Excelentíssimo Auxiliar da minha direita vai para a cadeira do Excelentíssimo Auxiliar da minha esquerda. E o Excelentíssimo Auxiliar da minha esquerda vai para a cadeira do Excelentíssimo Auxiliar da minha direita. Isto, ao mesmo tempo. Ao mesmo tempo? Sim, e vice-versa. Vice-versa? Exatamente. Depois ficam na nova cadeira uma hora, uma hora e meia... Muito bem. ... sempre a bater com os pés no chão... Os pés... ... e depois: vice-versa outra vez. Vice-versa outra vez como, Chefe? Mudam outra vez de lugar. Só há duas cadeiras, Chefe. Vice-versa duas vezes - questionou ainda, com um leve murmúrio, o outro Auxiliar - não é o mesmo que ficar tudo como estava antes? Não, porque é vice-versa ao mesmo tempo. [...]. Apesar de um ou outro engano, os dois Auxiliares cumpriram depois escrupulosamente as instrucõos. 
Vice-versa simultâneo e movimento no espaço[!] (Ibid., p. 2728, sublinhado nosso).

A ignorância do Chefe se expõe quanto ao uso da expressão viceversa, em que há total inversão da lógica e do bom senso, além da inutilidade da tarefa solicitada aos Auxiliares, em que a aparência ocupa o lugar do trabalho eticamente justificado.

Para contrapor sua voz crítica a tal estado de coisas, o senhor Kraus faz uso da paródia e da ironia em suas crônicas, no intuito de expor ao ridículo a figura do governante, ao mesmo tempo em que tenta levar o povo a refletir sobre a necessidade de discernir o bom do mau político.

Em outra crônica, "O dia seguinte às eleições (1)", o senhor Kraus prossegue em seu libelo crítico. Aqui, o novo Chefe eleito fala com um assessor, interessado em saber se ele, o funcionário, trabalha sozinho:

[...] Sozinho ninguém gosta de trabalhar. Na verdade, trabalho em conjunto com um outro funcionário que procura deixar as coisas sempre bem explicadas. Ótimo. Do trabalho conjunto resulta um equilíbrio entre o pouco e o muito. $O$ demasiado explicado e o pouco explicado. Não sei se o Chefe está a perceber...? Estou, e parece-me sensato. O nosso método de trabalho é o seguinte: o meu colega avança primeiro e explica a mais, depois surjo eu e digo: era desnecessário o meu colega ter explicado isto, isto e isto. Tal e tal e tal foi a mais. Muito bem. É uma estratégia (Ibid., p. 69-70, sublinhado nosso).

Como em um efeito em cascata, a incompetência e os abusos se desdobram por todos os níveis hierárquicos, do Chefe aos funcionários subalternos, revelando as esferas de poder viciadas, que provêm a si mesmas e nunca ao povo.

Em outra circunstância, o Chefe, utilizando de argumentação absurda, faz uma explanação aos Auxiliares sobre as vantagens dos impostos:

A questão é simples: os impostos servem para melhorar a vida do país. Certo? Certo. Portanto... Portanto: quanto mais 
impostos um indivíduo pagar, mais o país melhora a sua qualidade de vida. Ou seja... Ou seja: quanto menos dinheiro cada pessoa tiver por mês para viver - pelo fato de pagar mais impostos - mais dinheiro tem o país, no geral. No limite: quando alguém compra um pão com manteiga e o come, está, objetivamente, a roubar esse pão com manteiga ao país. Isto é: quanto pior cada pessoa viver melhor viverá o país. Exato. Viva pois o país! - exclamou o primeiro Auxiliar. O segundo concordou. A questão é: estamos a serviço dos interesses do cidadão singular ou do país como um todo? Do país como um todo, Chefe! - gritaram, em uníssono, os Auxiliares. [...]. Portanto, se o nosso objetivo patriótico é melhorar a qualidade de vida do país, o que temos a fazer é... Piorar a vida de cada cidadão! Aí está[!] (Ibid., p. 107-108, sublinhado nosso).

À semelhança de postulados matemáticos, o Chefe propõe formulações que não podem ser comprovadas, mas que ele, por meio de distorções de sentido, conclui como verdadeiras, como se pode observar no trecho citado. Usando de jogos de palavras, o Chefe manipula suas formulações, de forma a simular um possível favorecimento à população, rasurando o próprio significado de serviço público.

O que é ficcional nas crônicas do senhor Kraus, em relação às personagens, espelha metonimicamente a realidade do mundo social, em que as ações e as falas dos políticos da vida real não se distanciam sobremaneira daquelas descritas na sátira do jornalista. A voz crítica da imprensa se revela não apenas por meio das crônicas, mas também pelas anotações e comentários irônicos do jornalista. Em uma das notas, denominada "Causas" de constituição enigmática, o senhor Kraus escreve:

Queixava-se de não ter tempo sequer para comer, tal a sua dedicação à causa pública, no entanto não parava de engordar. Todos os que o rodeavam estavam assim convencidos de que a causa pública tinha qualquer coisa semelhante a um excesso de calorias (Ibid., p. 86). 
Certo dia, o senhor Henri encontra na rua o senhor Kraus, logo após as eleições: "Então, mudamos de Chefe?! Era o senhor Henri, já em estado de conversador por excelência. $O$ senhor Kraus sem abrandar o passo apenas respondeu: À primeira vista, à primeira vista[!]" (Ibid., p. 73).

Assim, a autenticidade e as boas intenções do jornalista estão em franca oposição à amoralidade dos políticos em geral, bem como se encontram em pontos diametralmente antagônicos a competência do profissional da imprensa, que exerce realmente o seu trabalho com zelo, e a incompetência dos governantes, que ocupam cargos públicos, os quais recebem por isso, mas não oferecem sua contrapartida de trabalho.

Ao cinismo do político opõe-se a ironia do jornalista, que se angustia com o que vê da parte dos governantes, sendo suas crônicas o protesto e a denúncia possíveis contra tal estado de coisas. Já o Chefe, alegra-se por motivos fúteis, regozijando-se em imaginar meios para ludibriar o povo, seja pelo falseamento de aparências ou pela simples omissão, no que é ajudado pelos zelosos Auxiliares.

Tais oposições são para Todorov (2006, p. 86) a revelação de pontos de vista distintos, e no caso das narrativas do senhor Kraus, dizem respeito não só à dupla narrador-leitor mas também às personagens. A tensão entre pontos de vista e posturas diversos é, pois, o motor da narrativa. As contradições de uma personagem são reveladas por outra, que prova o seu ponto, o que não significa que isso resultará em alterações imediatas na trama, mas, de todo modo, elas acrescentam elementos que podem, mais adiante, representar mudanças no curso narrativo.

Ainda para Todorov, tais considerações se relacionam à tipologia das intrigas, segundo as quais, durante o curso da narrativa, se passa de uma condição de equilíbrio a outra, mudando a relação das personagens entre si e delas com relação ao enredo. De acordo com ele, tal fato

[‥] significa a existência de uma relação estável mas dinâmica entre os membros de uma sociedade: é uma lei social, uma regra do jogo, um sistema particular de troca. Os dois momentos de equilíbrio, semelhantes e diferentes, estão separados por um período de desequilíbrio que será 
constituído de um processo de degradação e um processo de melhora (Idem, p. 88, sublinhado nosso).

É o que se pode observar em 0 senhor Walser. No início da narrativa, há o estado de equilíbrio caracterizado pela felicidade da personagem ao ver a casa pronta, sinalizando para tudo o que daí pode advir no futuro. Com a chegada dos especialistas da construção civil, instala-se um estado de desequilíbrio, refletido na desconstrução do imóvel e do sonho da personagem. O novo estado de equilíbrio reside na conformação desta à nova situação, tendo perdido o referencial físico da casa, agora irreconhecível, e estando, ele próprio, cercado pelo Outro indesejável.

Todorov conclui que o estudo desses aspectos em uma obra tem como função última, partindo da análise estrutural da obra literária, chegar à Literatura (sic),

[...] ou como diria Jakobson, a literaridade. [...]. Discutindo os fenômenos literários, fomos obrigados a introduzir certo número de questões, a criar uma imagem da literatura; essa imagem constitui a preocupação de toda pesquisa sobre a poética. [...]. As virtualidades que constituem o objeto da poética (como de toda outra ciência), essas qualidades abstratas da literatura, só existem no discurso da própria poética. Nessa perspectiva, a literatura é apenas um mediador, uma linguagem, da qual se serve a poética para falar (TODOROV, 2006, p. 89, grifo do autor, sublinhado nosso).

Em O senhor Kraus (TAVARES, 2007b, p. 118-119), a narrativa segue em equilíbrio estável do começo até o momento do desequilíbrio literal do Chefe, que equivaleria a uma espécie de punição da vaidade, quando, por um descuido fatal, ele cai da varanda do $4^{\circ}$ andar pelo fato de se ter debruçado em excesso, estimulado que fora, por um dos Auxiliares, a admirar a sua própria expiração. 
Já nas histórias do senhor Brecht, revelam-se situações próprias do cronotopo do limiar, em que os aspectos sensoriais de dor e mutilação estão, de um modo ou de outro, presentes em várias narrativas, muitas delas culminando com a morte. Aqui o tempo/espaço é o do sofrimento, da violência, do medo essencial do homem diante do inexorável, sendo o novo estado de equilíbrio sempre pior que a situação inicial.

Há um jogo constante de submissão e domínio, em que prevalece uma atmosfera opressora, na qual a parte mais fraca é invariavelmente a grande vítima. A mais contundente delas é "Desempregado com filhos", que focaliza uma das mazelas sociais da contemporaneidade - a falta de emprego situação em que estão em jogo a autoestima e a sobrevivência dos indivíduos, além do jugo do poder que, ao mutilar o corpo, amputa a alma:

Disseram-lhe: só te oferecemos emprego se te cortarmos a mão. Ele estava desempregado há muito tempo; tinha filhos, aceitou. Mais tarde foi despedido e de novo procurou emprego. Disseram-lhe: só te oferecemos emprego se te cortarmos a mão que te resta. Ele estava desempregado há muito tempo; tinha filhos, aceitou. Mais tarde foi despedido e de novo procurou emprego. Disseram-lhe: só te oferecemos emprego se ter cortarmos a cabeça. Ele estava desempregado há muito tempo; tinha filhos, aceitou (TAVARES, 2005, p. 17, sublinhado nosso).

Nesse caso, o desempregado, para quem não há saída viável ou a possibilidade de escolhas não coercitivas, há que considerar que o trabalho metaforiza não apenas a dominação de um lado, e a aceitação incondicional do outro, mas é usado como moeda de troca para a penalização extrema - a mutilação - que, se não desaguar na morte, resultará, paradoxalmente, em impeditivo absoluto para o próprio trabalho.

O tom de impessoalidade do narrador está em oposição ao conteúdo do que é narrado, já que para o senhor Brecht não importa o fato de contar histórias para uma sala quase vazia, ou a crueldade do conteúdo narrado. Igualmente, não transparece nas narrativas o sentimento das vítimas. Os fatos 
são objetivamente contados, como se aquele senhor estivesse lendo relatos banais, o que reforça a ideia de um contador de histórias indiferente e distanciado do público ouvinte.

Em "Os sábios", à semelhança de uma fábula, "Uma galinha, finalmente, descobriu a maneira de resolver os principais problemas da cidade dos homens" (Idem, p. 68).

A ave apresenta sua descoberta aos homens sábios do lugar: "[...] ela tinha descoberto 0 segredo para todas as pessoas poderem viver tranquilamente e bem" (Ibid., p. 68). É, então, ouvida por sete sábios, que solicitaram um tempo para pensar sobre as consequências da descoberta, ficando a galinha a aguardar, ansiosa, em uma sala. "Na reunião, os sete sábios por unanimidade, e antes que fosse tarde demais, decidiram comer a galinha" (Ibid., p. 68).

Mais uma vez, o poder dos mais fortes subjuga os mais fracos. Para não perderem a posição privilegiada de "sábios", estes decidem matar quem os ameaça. A galinha representa aí o indivíduo que se distingue por sua competência, o diferente, o mais preparado para enfrentar os problemas, e que justamente por isso, representa perigo, sendo então sumariamente eliminado.

Nos relatos do senhor Brecht, é possível notar, embora em enredos distintos, que as personagens são de regra confrontadas com situações para as quais não é oferecida qualquer saída. Trata-se de um universo de indivíduos sem lugar no mundo, oprimidos, sem ter quem os defenda, restando-lhes, como único destino possível, a submissão ao sistema, a loucura, a mutilação ou a morte, vivendo todos, não um tempo biográfico, mas um tempo do limiar.

Ao terminar de narrar suas histórias, o próprio narrador se torna igualmente um sujeito do limiar, já que a sala, quase vazia no início, se torna, ao final, lotada de ouvintes. O senhor Brecht toma consciência, então, da própria angústia que lhe causam as pessoas à sua volta, o Outro inesperado.

O narrador, aparentemente indiferente às perversões que narra, não sabe o que fazer diante da alteridade, cuja ausência, no princípio, não o incomodara, mas cuja presença, ao final, o angustia: "[...] o senhor Brecht 
olhou em redor. A sala estava cheia. [...]. Como poderia agora sair dali[?]" (Ibid., p. 69, sublinhado nosso).

As imagens ${ }^{42}$ abaixo mostram a sala em que está o senhor Brecht, à semelhança de um auditório. Da esquerda para a direita, vê-se a progressão de tempo da sala praticamente vazia, quando ele começa a narrar, até o momento em que ele termina, e a sala está completamente lotada, o que the causa enorme desconforto.
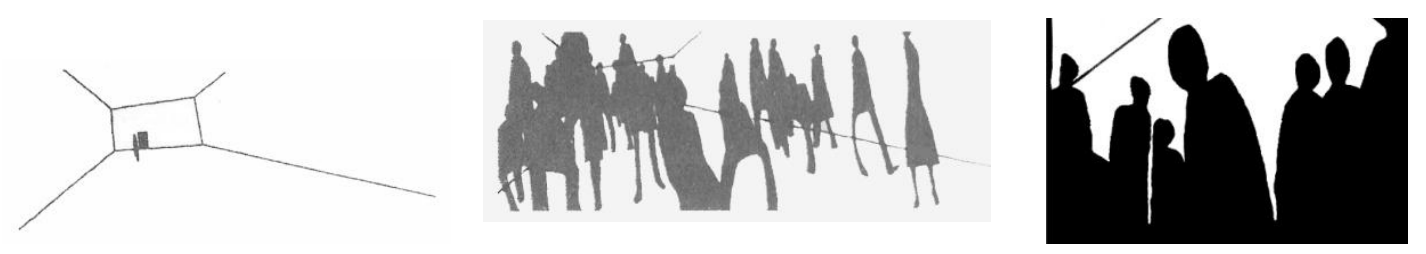

No caso do mundo do senhor Valéry, observa-se que, mais do que nos dos demais senhores, a estruturação se dá sobre elementos e realidades duais: suas duas vontades: X e Y (TAVARES, 2004a, p. 33); os dois lados que as coisas têm: o esquerdo e o direito (p. 15); as cores vermelha e azul para distinguir os lados esquerdo e direito do corpo e dos objetos (p. 18); as pessoas altas e as baixas ( $p$. 7); a não distinção entre o chapéu e o cabelo ( $p$. 13); a dupla divisão da sua casa (p. 15), etc. Ele próprio se vê como um indivíduo dual: o homem que fora um dia e o que é no presente (p. 57).

De todos os senhores, ele é também o mais ambíguo, e os recursos dos quais se utiliza, como proteção contra um desconforto intrínseco e permanente, reforçam para ele a ideia de que não se sente seguro, não importando o que faça para se sentir melhor: "Enquanto um dia se seguir ao outro, tudo bem. $O$ problema deste negócio - sussurrava o senhor Valéry, como a querer que ninguém o escutasse - o problema é se eu morro. Esse é o problema" (Idem, p. 43, sublinhado nosso).

Para tal questão, o da ruptura do ciclo da vida pela morte, o senhor Valéry não consegue propor qualquer solução, já que esta representa não

\footnotetext{
${ }^{42}$ Desenhos de Rachel Caiano. In: TAVARES, Gonçalo M. O senhor Brecht. Rio de Janeiro: Casa da Palavra, 2005, p. 13, 53 e 69, respectivamente.
} 
apenas a quebra do fazer cotidiano, mas também das rotinas de sistematização que ele se impõe. Morrer significa o mergulho no desconhecido, a perda do poder de manipulação das situações e dos objetos, a impossibilidade absoluta de "reorganização" sob qualquer padrão.

Esta é a razão da sua angústia: o confronto final com o inexorável, o que não pode ser manipulado, o próprio limiar em sua condição extrema. $O$ fato de sussurrar para que não o ouçam é um meio de evitar que a voz, em tom mais alto, possa atrair a morte, da qual deseja fugir.

Por essa mesma razão, ele não gosta da sua sombra, o seu lado escuro e desconhecido, prenúncio da morte e do imponderável que nunca se anuncia, pois "[...] considerava-a como a pior parte de si próprio. [...]. O senhor Valéry explicava: É uma mancha que por vezes se torna visível e anuncia a morte" (Ibid., p. 73, sublinhado nosso).

Em "A chávena de café", o senhor Valéry prossegue em sua linha de raciocínio, buscando elementos concretos para se assegurar da sua realidade instável:

Sem café não consigo trabalhar - e quem o ouvia julgava-o
dependente dessa substância para fazer uma outra coisa. Mas
não. O senhor Valéry explicava: Um corpo é tanto mais exacto
quanto menos tarefas faz. E clarificava ainda, exibindo as
ideias filosóficas de que tanto se orgulhava: Uma causa vale
menos do que um efeito e um efeito vale menos do que um
$\underline{\text { acontecimento sem causa. Por isso ele agia sem pensar nos }}$
efeitos da sua acção. Agia porque gostava da acção que fazia.
E bastava-lhe. O senhor Valéry, decidiu, então, desenhar uma
chávena de café para provar a sua teoria. Há dias em que não
percebo nada de mim. E como se encontrava confuso, o
senhor Valéry decidiu ir beber um outro café. É uma maneira
de resolver as coisas - pensava (Ibid., p. 48 , sublinhado
nosso).

Nota-se aí uma tentativa de apagamento da relação lógica de causa e efeito, ao mesmo tempo em que o desenho da xícara concretiza a realidade 
para alguém que, às vezes, perde a noção de si mesmo, tornando-se o objeto físico como que uma prova da realidade que às vezes lhe escapa. Ao sentir-se confuso, ele necessita de coisas e ações concretas que o façam, de algum modo, recuperar o referencial temporariamente perdido.

Outro índice revelador dos temores do senhor Valéry aparece quando ele fala das suas visões. Em "O escadote fantasma", ele relata:

Por vezes, em certas noites, surgem-me à frente dos olhos, na minha própria casa, objectos que nunca vi na vida. São objectos que pertencem aos antigos proprietários da casa, objectos que se partiram ou foram destruídos. Olho para a minha mesa e vejo sobre ela um copo que nunca tive. Desloco a minha visão para o canto da sala e lá está um escadote que nunca comprei. Uma vez $[$...] tentei subir pelo escadote fantasma, e caí. O escadote, de repente, tinha desaparecido. Poderia ter partido uma perna, mas felizmente por baixo de mim apareceu, entretanto, um colchão fantasma (Ibid., p. 75, sublinhado nosso).

É possível verificar que o senhor Valéry, mesmo em suas visões, quando confrontado com um problema, já encontra de imediato a solução: para amortecer a queda da escada fantasma, ele produz, em sua imaginação, um colchão fantasma que the suaviza a queda.

Vítima constante dos seus temores, o senhor Valéry tenta se proteger de muitas coisas, como se estivesse permanentemente ameaçado. Assim, ele tem medo de objectos-fantasma (p. 75), de ladrões (p. 71), da sua sombra (p. 73), de perder-se (p. 28), do sofrimento (p. 55), da chuva (p. 19), de dormir (p. 29), da perda não apenas do controle, mas da própria identidade. Os recursos de que se utiliza convergem todos para que das partes se faça o todo, recompondo, ao menos em parte, o mosaico fragmentado que constitui a sua pessoa, sempre no limiar de uma crise.

Os verbos, adjetivos e substantivos usados pela personagem, ou enunciados pelo narrador onisciente, são indiciais do medo constante que acomete a personagem. Desse modo, por confundir o chapéu com o seu 
cabelo, o senhor Valéry, com "medo do ridículo [...] passou a precaver-se e antes de sair de casa enterrava o seu chapéu de coco até ao fundo da cabeça para ter a certeza de que o levava [...]" (Ibid., p. 13, sublinhado nosso).

Ou ainda: "O senhor Valéry tinha medo da chuva. [...]. Ele dizia: É assim que eu fujo à chuva. E desenhava, representando-se a si próprio como uma seta" (Ibid., p. 19, sublinhado nosso). Na imagem ${ }^{43}$, ele se transforma em objeto que lhe permite passar por entre os pingos.

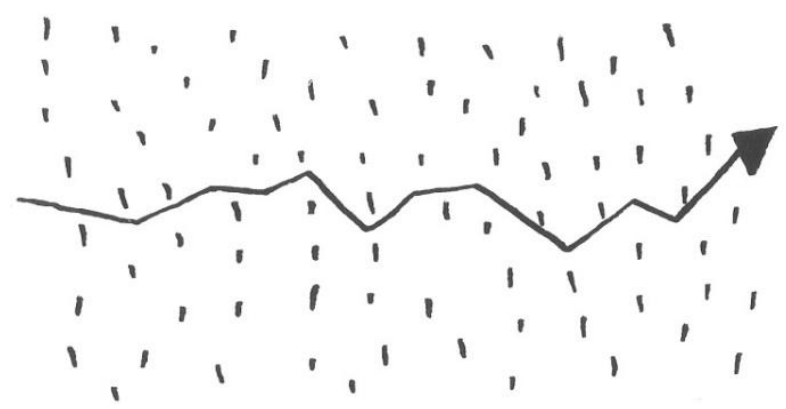

Ao planejar sua casa de férias, "a casa das quatro portas juntas", Valéry o faz por uma razão: "Evitarei perder-me em compartimentos [...]. É que só consigo repousar se não tiver que decidir nada, e para que isso aconteça é indispensável não existirem opções" (Ibid., p. 28, sublinhado nosso). Para o senhor Valéry, opções não são oportunidades, mas riscos que ele teme correr.

Assim, o medo vago e sempre presente que sente este senhor está ligado a um medo maior, existencial e definitivo, o qual ultrapassa todos os outros: "O Destino - disse, por fim, o senhor Valéry - isso é que desconheço o que seja" (Ibid., p. 21).

O senhor Valéry é também vítima de comportamentos obsessivos, seja nos cronotopos da rua ou da sala de visitas, este último representado por sua casa. Quando dialoga com alguém ou consigo mesmo, este senhor expõe suas metodicidades, compulsões e manias. Dessa maneira,

O senhor Valéry tinha como profissão, em dias alternados, vender e comprar. Vendo o que comprei no dia anterior explicava o senhor Valéry - e no dia seguinte compro algo com

${ }^{43}$ Desenho de Rachel Caiano. In: TAVARES, Gonçalo M. O senhor Valéry. Porto Alegre: Escritos, 2004a, p. 19. 
o dinheiro que fiz da venda do dia anterior. E assim se vai sobrevivendo - concluía. [...]. E como gostava muito de desenhar, o senhor Valéry desenhava ${ }^{44}$ (Ibid., p. 42).
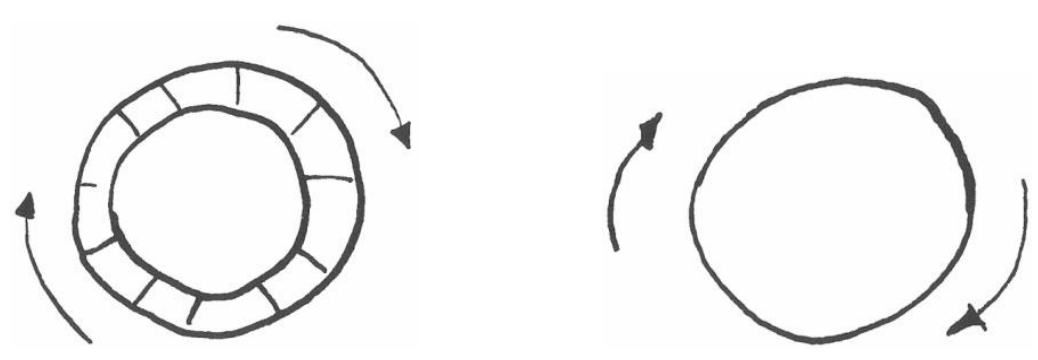

O círculo é representa a rotina cíclica e repetitiva desse senhor, a qual, embora o submeta à monotonia, também provê a segurança relativa de que um dia se segue ao outro. É a repetição contínua, ainda que pontuada por patologias ligadas aos ordenamentos, que dá garantia aos senhores de que são capazes de tomar decisões por si mesmos.

Tal pode se estender, por analogia, ao homem contemporâneo, que ancora sua segurança em uma agenda de rotinas meticulosamente organizadas, a partir das quais, o script é metodicamente seguido.

Quanto às narrativas em 0 senhor Henri, vale ressaltar a presença do cronotopo rabelaisiano, seja nas enumerações ligadas às suas exibições de pseudoerudição, seja nos elogios exagerados ou nas ofensas copiosas que profere no bar/sala de visitas. De acordo com Bakhtin, para Rabelais,

Era preciso destruir e reconstruir todo esse falso quadro do mundo, eliminar todas as camadas intermediárias que as separavam. Era necessário liberar todas as coisas, permitir que entrassem numa combinação livre, característica de sua natureza, [...]. Era necessário permitir que as coisas tivessem um contato vivo e carnal, um contato com suas qualidades multiformes. [...] era preciso justapor e reunir o que fora falsamente desunido e afastado, e também separar o que fora

\footnotetext{
${ }^{44}$ Desenhos de Rachel Caiano. In: TAVARES, Gonçalo M. O senhor Valéry. Porto Alegre:
} Escritos, 2004a, p. 42. 
falsamente reunido. Com base nessa nova vizinhança, devia surgir um novo quadro do mundo, penetrado por uma necessidade interior verdadeira. Desta forma, em Rabelais a destruição do velho quadro e a elaboração positiva do novo estão indissoluvelmente entrelaçadas (BAKHTIN, 1988, p. 284, sublinhado nosso).

Bakhtin menciona ainda o fato de que certos conceitos e símbolos religiosos, já existentes de modo paródico e corrompido desde a Idade Média, também estão presentes no cronotopo de Rabelais na forma de '[...] 'fórmulas' de injúrias obscenas, que ainda não tinham perdido inteiramente sua antiga significação religiosa; tais injúrias eram amplamente empregadas na linguagem corrente oficiosa, da qual constituíam a originalidade estilística e ideológica (sobretudo nas classes sociais inferiores)" (Idem, p. 298, grifo do autor).

A retomada do cronotopo rabelaisiano em 0 senhor Henri (TAVARES, 2004b), evidencia-se nas misturas que faz a personagem de injúrias, maldições e outros elementos que fazem referência à ciência e à religião, somados a ofensas pessoais, recurso presente no cronotopo de Rabelais, que é transformar, por meio do exagero e do excesso, algo pequeno em um evento significativo.

É o que acontece quando alguém espirra no bar, fato aparentemente banal que, para o senhor Henri, se transforma repentinamente no mais grave dos crimes, pela quantidade e pelo teor de reprimendas e xingamentos que ele dirige a quem ousou cometer tal ato naquele "honrado estabelecimento" (p. 90).

Em dado momento, interrompendo os impropérios, o senhor Henri alega estar brincando, fato que não o impede de prosseguir nas ofensas: "[...] ... estou a brincar consigo. Vossa excelência não percebe o meu humor, é um iletrado, um analfabeto e um imbecil [...]" (Idem, p. 94, sublinhado nosso).

Sofrendo os efeitos do absinto, representados pelo uso das reticências que separam as porções das falas deste senhor, somados às tortuosidades e inversões de sua lógica particular, o senhor Henri se serve de afirmações aparentemente incompreensíveis para externar a sua aparente sabedoria, como em "Os terramotos": "[...] se querem abrir um poço o melhor é 
descobrirem primeiro um formigueiro" (Ibid., p. 33). Nesta instância, em um desenvolvimento de lógica paralela, em que possivelmente 0 álcool desempenha papel relevante, o senhor Henri explica:

[...] ... é que toda a gente sabe que debaixo de um formigueiro há muita água. ... as formigas são, assim, plantas metade inteligentes e a outra metade burras, enquanto as plantas são animais sem inteligência nenhuma. ... as formigas precisam de água para constituir uma família. E nisso são iguais aos homens (Ibid., p. 33, sublinhado nosso).

Seguindo a sua lógica descentrada, ele vai associativamente estabelecendo postulados e silogismos a partir de premissas e generalizações assumidas como verdadeiras, tal como a afirmação de que "toda a gente sabe que debaixo de um formigueiro há muita água" (Ibid., p. 33). Ele também é capaz de estabelecer igualdade entre elementos de naturezas diversas, como se pode ver abaixo, a partir da última citação:

- As formigas são iguais às plantas, com a ressalva de que tal igualdade não é idêntica, já que as formigas, segundo o senhor Henri, são "[...] plantas metade inteligentes e a outra metade burras" (p. 33). O inverso, todavia, não é verdadeiro, uma vez que "[...] as plantas são animais sem inteligência nenhuma" (p. 33).

- Silogismo final, dedutível a partir do raciocínio pelo avesso do senhor Henri: se as formigas precisam de água para constituir família, assim como os homens, então as formigas "[...] são iguais aos homens" ( $p$. 33), fato que estabelece uma igualdade improvável.

O senhor Henri ora elogia e se refere aos atendentes do bar e aos frequentadores usando pronomes de tratamento cerimoniosos, ora os rebaixa com xingamentos e esconjurações. Da mesma forma pela qual dirige encômios aos seus improváveis ouvintes, também dispara ofensas de toda ordem quando acontece algo que o desagrada, como o espirro, por exemplo: 
[... ... vossa excelência fique a saber que é um hipócrita, e a partir de hoje não me dirija a palavra. ... faz favor de fazer a minha conta, caro comendador, e peço desde já desculpas pelo meu nervosismo, mas o excelentíssimo patrão tem aqui na sua sala de visitas alguns intrusos que não dignificam este nobre chão que pisam. ... boa tarde, meus senhores, no geral, e má tarde para si, caro inimigo. [...]. ... vossa excelência desapareça do meu ar, que vossa excelência contamina até as bactérias já doentes. ... vossa excelência tem mais veneno que uma família de lacraus e que uma assembleia cheia de políticos, não necessariamente por esta ordem [...] (Ibid., p. 9293, sublinhado nosso).

Em relação a si mesmo, os elogios crescem no decorrer da narrativa:

"[...] ... podem crer, excelentíssimos ouvintes, que vos falo, não por via de uma erudição, que sem dúvida alguma possuo em grandes quantidades; mas não, não é por aí que a minha voz vem" (Ibid., p. 65, sublinhado nosso). E ainda:

"[...] ... e vossas excelências reflictam bem no que o senhor Henri vos está a dizer, que o senhor Henri é muito cerebral. ... enquanto a maior parte das pessoas é cerebral daqui para cima, eu sou cerebral daqui para cima e daqui para baixo. ... sou cerebral em todas as direcções [...]" (Ibid., p. 67, sublinhado nosso).

Ao fazer pedidos de bebida aos balconistas, revelando já um alto grau de embriaguez, o senhor Henri aumenta a formalidade da linguagem e o nível dos elogios. Nesta instância, as suas falas se tornam mais cerimoniosas e rebuscadas, mesmo ao falar de funções fisiológicas, tema impróprio para ser tratado em um lugar público, expressões estas que vêm acompanhadas de pronomes pessoais, de tratamento, de adjetivos e de outros adjuntos adnominais crescentemente enaltecedores, o que se pode perceber nos trechos a seguir, nos quais os sublinhados são nossos:

"[...]. ... mais um copo de absinto, caro imperador, que o anterior vinha com pressa" (p. 69); 
"[...]. ... mais um copo de absinto!, excelentíssimo $2^{0}$ outorgante aqui presente" (p. 72);

"[...]. ... arrotar é a linguagem dos meus antepassados e peço, desde já, desculpa por ser tão agarrado à família e por ter incomodado vossas excelências" (p. 77).

Quanto às manifestações do seu conhecimento enciclopédico, ainda que se trate de uma aproximação manipulada em relação ao saber canônico e formal, geralmente invertida e desconexa, é certo que tal atividade o mantém ocupado fora do período em que está no bar, o que provavelmente the preenche, em certa medida, o vazio existencial. Além disso, tal recurso Ihe dá parâmetros concretos, bem como referenciais da realidade, ordenando, em parte, uma esfera da sua vida, já que as demais restam desorganizadas.

Dessa maneira, ele afirma peremptoriamente, atribuindo qualidades implausíveis aos objetos: "... um facto é que os ossos não se embebedam porque a bebedeira é sempre uma coisa superficial" (Ibid., p. 86). Ou ainda: "O absinto torna os osso compactos, firmes inteligentes, ágeis, flexíveis, duradouros, vigilantes e, além disso, é bom para os ossos" (Ibid., p. 86).

Pode-se falar aí de um saber pelo avesso, com ramificações para muitas áreas do conhecimento, sem a preocupação de estabelecer nexo formal, representativo do que seria o equivalente ao processo rabelaisiano de contiguidade, conforme descrito por Bakhtin (1988, p. 306), mas que adquire feição própria quando se trata do senhor Henri.

Ele igualmente faz uso generalizado de truísmos e/ou afirmações, nas quais predomina a circularidade, além de hipóteses, analogias, comentários, definições, metáforas, comparações e deduções aparentemente absurdas, se vistas à luz da lógica ortodoxa. Citamos algumas, nas quais os sublinhados são nossos:

"[...] ... o telefone foi inventado para as pessoas poderem falar afastadas umas das outras. ... o telefone foi inventado para afastar umas pessoas das outras" (TAVARES, 2004b, p. 75); 
"[...] ... o Dr. Guillotin, anatomista, dizia que a guilhotina é muito mais rápida que o machado e, portanto, faz sofrer menos. [...] ... é necessário estudar o corpo com muita atenção para conseguir matá-lo com rapidez - [...]. ... qualquer idiota, como o Tempo, demora 70 anos a matar uma pessoa. [...].... é, pois, de concluir que o Tempo não é um estudioso da anatomia humana " ( $p$. 39);

“[...] ... o microscópio é o invento mais importante para a democracia. ... um pobre ao microscópio tem tantos vermes e tantas cores como um rei. [...].[...] ... os Gregos foram mais ou menos uma democracia sem microscópio o que é, de facto, uma grande porcaria" (p. 61-62);

“[...] ... quando o senhor Henri vos faltar é que vão sentir a falta” (p. 80);

"[...]... li um tratado de anatomia onde os autores se tinham esquecido das duas pernas e de um dos braços. [...]. [...] ... é como o resumo da Bíblia sagrada em três páginas A4 com 25 ilustrações" (p. 86-87).

Assim, a lógica peculiar do senhor Henri o faz afirmar que o microscópio é um invento "democrático" por mostrar o que é fisiologicamente comum a todos os homens, nobres e plebeus, conectando, em seguida, por associação imprópria, mas condizente com o seu raciocínio peculiar, o microscópio à democracia grega. Em outra citação, o tempo é antropomorfizado, já que "[...] não é um estudioso da anatomia humana" (Ibid., p. 39).

Ainda que o senhor Henri se refira a alguns temas por vezes abstratos como as religiões e a filosofia, é de deduzir que a flagrante preferência da personagem por temas e fatos históricos e científicos, invenções, datas e números, constitui, de per si, uma tentativa de tornar concreto algo que o conecte de maneira física à realidade do seu entorno, em oposição ao escapismo e à desconexão causados pela solidão e pelo uso contínuo do álcool, fatos que colocam esse senhor em estado de crise permanente, refletida nas suas atitudes e no seu discurso.

Quanto ao senhor Breton, a angústia de sentir-se só e incapaz de responder a questões ligadas ao intangível e à imaterialidade o levam à tentativa de autoconhecimento, em que uma parte de si entrevista a outra 
parte, como se fossem duas personagens distintas. Há, pois, ao final de cada pergunta, uma imposição do entrevistador para com ele próprio, na posição de entrevistado, que é a de prosseguir os questionamentos num ritmo cada vez mais acelerado. Entrevistador e entrevistado se colocam, pois, em um plano de tensão de forças opostas desde o início, em que uma parte deseja obter respostas e a outra é incapaz de dá-las. A própria cisão em duas personae é reveladora da desintegração da personagem e da sua linguagem.

A ambivalência de entrevistador e entrevistado compele o primeiro a entrar por raciocínios complexos em face de questões igualmente difíceis. Já o segundo, de modo complacente, aceita a imposição do entrevistador, permitindo-se, de vez em quando, pequenos e inúteis intervalos de escape, nunca tendo o que responder frente aos incisivos questionamentos do entrevistador.

A entrevista retoma o protótipo do diálogo socrático, o qual, segundo Bakhtin (2005, p. 109), não constitui um gênero retórico per se, ainda que se sirva de elementos da Retórica, como o debate sobre a verdade. Todavia, ele se desenvolve em base carnavalesco-popular, tendo sido marcado, especialmente em seu estágio oral, por elementos da cosmovisão carnavalesca, em que as inversões e distorções das festas do carnaval são transpostas para a literatura. Em sua fase literária, o diálogo socrático se firmou como um gênero confessional ou memorialístico, o qual consistia de lembranças das palestras de Sócrates segundo uma organização narrativa.

Esse gênero é, pois, eminentemente dialógico, por basear-se na concepção do filósofo que the empresta o nome, de que a verdade só se pode revelar mediante o confronto pressuposto pelo diálogo. Tal visão já mostra, de antemão, não haver uma única verdade, acabada, oficial e monológica.

Usando dos recursos da anácrise e da síncrise (Idem, p. 110), o protótipo busca persuadir o interlocutor acerca da sua verdade. De início, utiliza-se a anácrise, que busca extrair do interlocutor suas visões e opiniões, exercendo o que se poderia caracterizar como a provocação da fala pela fala, base da relação dialógica. Em seguida, por meio da síncrise, que expressa 0 confronto de posições, chega-se à culminância do processo, o que ocorre pela 
conversão do pensamento em diálogo, predominando a posição do interlocutor capaz de fazer valer "a sua verdade" por via de argumentação mais efetiva.

Tal é o objetivo do senhor Breton durante a entrevista: convencer o entrevistado da veracidade das suas afirmações, a principal razão para os arrazoados argumentativos que precedem cada pergunta.

Ainda segundo Bakhtin (Ibid., p. 110-111), graças ao exercício desses dois procedimentos - a anácrise e a síncrese -, o diálogo socrático perdeu seu caráter estritamente retórico-abstrato, adquirindo concretude dialógica pelas falas em confronto, tornando-se igualmente, a matriz responsável pela introdução, na literatura europeia, da figura do herói-ideólogo, papel desempenhado na narrativa tavariana pelo senhor Breton na posição de entrevistador.

Assim como para o diálogo socrático é mais importante a busca da verdade do que a verdade acabada, também as narrativas da contemporaneidade apresentam-se como terreno para a experimentação de verdades, em que o embate dialógico das vozes define não apenas o fenômeno do plurilinguismo como o processo de inacabamento.

Em O senhor Calvino, é possível notar que, em certos momentos, emerge o diálogo socrático, imbricado na ficção contemporânea. Após o jogo com o senhor Duchamp, "Como não haviam definido as regras, a coisa não estava clara: Precisamos de definir as regras para saber quem ganhou, se eu, se o senhor... - disse o senhor Duchamp a Calvino, recolhidas que estavam já todas as peças e o jogo concluído" (TAVARES, 2007c, p. 31).

É de ressaltar que, nesse caso, já de princípio está rompida a noção de contrato, uma vez que os dois senhores são capazes de jogar sem 0 estabelecimento de regras, o que representa uma quebra da lógica formal. A partir da própria concepção bakhtiniana do dialogismo, o jogo pressupõe, de antemão, a interação Eu-Outro, que garante as bases para que se processe, em terreno conhecido das partes, as operações e etapas que devem ser as mesmas para os dois lados, incluindo as negociações estratégicas, típicas dos jogos, além das conversacionais. 
Para Patrick Charaudeau,

A noção de contrato pressupõe que os indivíduos pertencentes a um mesmo corpo de práticas sociais sejam capazes de entrar em acordo a propósito das representações de linguagem destas práticas. Consequentemente, o sujeito que se comunica sempre poderá, com certa razão, atribuir ao outro (o não-EU) uma competência de linguagem análoga à sua que o habilite ao reconhecimento. $\mathrm{O}$ ato de fala transforma-se, então, em uma proposição que o EU dirige ao TU e para a qual aguarda uma contrapartida de conivência (CHARAUDEAU, 1983 apud MAINGUENEAU, 1997, p. 30, grifo do autor).

Em 0 senhor Juarroz emerge uma situação em que subjaz também o diálogo socrático. Isto se dá quando este senhor e a sua esposa, divergem quanto ao uso que ele faz da "gaveta para guardar o vazio" (p. 13). Aqui se dá o embate pela palavra, em que ela, com "[...] cada vez menos espaço em casa, protestava por aquilo que considerava ser uma péssima utilização do metro quadrado (TAVARES, 2007a, p. 13, grifo do autor).

O senhor Juarroz, por seu turno, quer "[...] impedir que a sua gaveta fosse ocupada por objetos desinteressantes, transformando-se num mero depósito" (Idem, p. 13). O confronto se dá pelas visões distintas do conceito de utilitário que cada um tem, em que pese a lógica atípica do senhor Juarroz, e por essa mesma razão, os significados distintos e opostos, que ambos atribuem ao mesmo objeto:

[...] o senhor Juarroz por vezes abria-a, irritado, exibindo-a à sua esposa como quem exibe um tesouro: $\underline{\text { A gaveta está }}$ totalmente vazia! - exclamava logo a esposa, como que a dizer: é o momento de a ocupar. Mas o senhor Juarroz discordava com a cabeça: Ainda não está totalmente vazia. [...]. (Ibid., p. 13-14, sublinhado nosso). 
$O$ valor diferente que marido e mulher conferem à gaveta, mediado pela ideia atributiva de cheio e vazio, pode ser notado a partir dos dêiticos nominais tesouro, para o senhor Juarroz, e utilização, para a sua esposa.

Todavia, nesse caso, não há o convencimento da verdade pelo marido com relação à esposa e vice-versa. Há a obstinação da parte dele e a concordância resignada dela, como em uma espécie de rasura da ideia original do protótipo.

Em O senhor Valéry, o convencimento acerca de uma verdade não se dá na relação Eu-Outro, o que para este senhor é extremamente difícil. Neste caso, o processo de persuasão parte do senhor Valéry em relação a si mesmo e ao leitor, em um processo assemelhado ao do senhor Breton.

Ao sair de um tribunal, onde versões contraditórias de um mesmo evento foram ouvidas, o senhor Valéry, por meio de desenhos, expõe a "sua verdade", em um processo metalinguístico, no qual está em discussão a própria ideia de verdade, a partir de um jogo de palavras. Assim, ele afirma: A única hipótese da verdade sobreviver é multiplicá-la. Se a verdade é uma única, e a mentira pode ser todos os biliões de possibilidades que restam, [...] então, descobrir a verdade será quase impossível (TAVARES, 2004a, p. 51, sublinhado nosso).

Ao formular teorias, que nada mais são que tentativas ordenatórias de concretização e harmonização do mundo, os senhores buscam aproximar-se do que para eles é complexo ou distante, simplificando e reduzindo tudo ao básico essencial, ainda que por vias tortas. Tal fato aproxima as ideias do senhor Juarroz às do senhor Valéry, especialmente quanto a questões de lateralidade, promotoras de certa sensação de segurança. Para o primeiro, "O veneno está só no lado esquerdo do cogumelo venenoso - [...], que, como há muito tempo não saía, estava convencido de que a realidade apenas tinha uma dimensão, como o desenho na folha de papel. Pode-se sempre comer o outro lado - dizia" (TAVARES, 2007a, p. 11).

Corroborando a ideia de semelhança entre os dois senhores, diz o senhor Valéry: 
O Mundo tem 2 lados: o direito e o esquerdo, tal como o corpo; e o erro surge quando alguém toca o lado direito do Mundo com o lado esquerdo do corpo, ou vice-versa. Seguindo escrupulosamente esta teoria, o senhor Valéry explicava: Eu dividi a minha casa em dois, com uma linha. $E$ desenhava ${ }^{45}$ [...]. Defini um lado direito e um lado esquerdo (TAVARES, 2004a, p. 15).

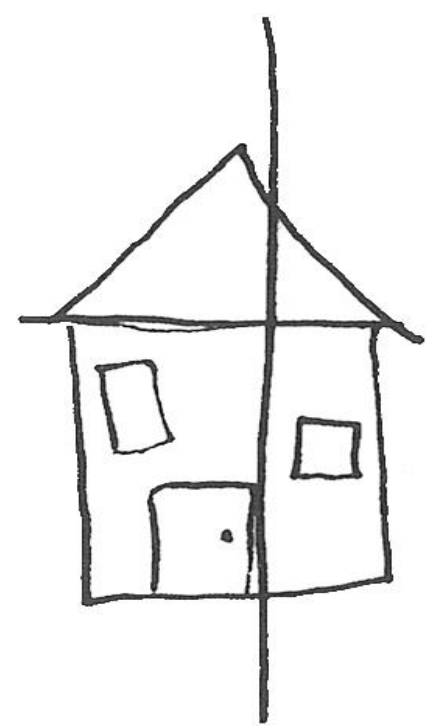

Quanto ao senhor Henri, ao discursar no cronotopo do bar, tenta provar também a "sua verdade", por exemplo, acerca dos méritos do absinto. Analogamente, os demais temas explorados em suas falas públicas não estão destinados a apenas exibir a sua pseudo-erudição, mas também demonstrar a importância do conhecimento, ainda que à sua maneira: "[...] ... eu leio diariamente a enciclopédia para poder ter acesso a estas informações imprescindíveis - disse o senhor Henri. ... é impossível um homem viver sem informação. ... a informação - disse o senhor Henri, já com a língua meio enrolada - a informação é o outro lado do absinto" (TAVARES, 2004b, p. 34, sublinhado nosso).

Assim, em relação à realidade dual do senhor Henri, que se divide entre a bebida e o conhecimento enciclopédico, a personagem faz a defesa de

\footnotetext{
45 Desenho de Rachel Caiano. In: TAVARES, Gonçalo M. O senhor Valéry. Porto Alegre:
} Escritos, 2004a, p. 15. 
ambos, dada a importância que thes confere, igualando o que não pode ser comparado.

Também o senhor Kraus, ao exercer a crítica jornalística da esfera política inepta e corrupta, tenta igualmente persuadir o seu leitor quanto à "sua verdade", desempenhando, por meio da sátira, o seu papel de homem da imprensa. Ao expor os desmandos do poder, é sua intenção convencer não apenas pela força de sua habilidade de jornalista, mas também pela reflexão do leitor.

Quanto ao senhor Breton, suas perguntas, feitas da posição de entrevistador, se referem a questões profundas, relacionadas à arte, à filosofia, à literatura especificamente, enfim, aos propósitos do homem no mundo. Em última instância, elas representam questionamentos existenciais e ontológicos para os quais o senhor Breton, na posição de entrevistado, não tem respostas. Trata-se aí de buscar a verdade de si mesmo e a verdade do Outro pela cisão do Eu.

De fato, ocorre aqui, indo um passo além do diálogo socrático, a retomada do protogênero das últimas questões, a menipeia, que, juntamente com o diálogo socrático, estão entremeados na natureza constitutiva de várias das narrativas em Os Senhores, de Gonçalo M. Tavares.

Sucedendo ao diálogo socrático, a sátira menipeia, impregnada igualmente da cosmovisão carnavalesca, constitui a raiz histórica propriamente dita, a partir da qual, evoluiu a prosa literária europeia moderna. O protótipo deve o seu nome ao filósofo Menipo de Gádara ${ }^{46}$, que conferiu às suas sátiras a forma clássica do gênero.

\footnotetext{
${ }^{46}$ Menipo de Gádara: (Fenícia, primeira metade do século III a.C.). Foi, como a maioria dos cínicos da época, um escritor sarcástico e burlesco. Diógenes Laércio* conta que não havia nele nenhuma seriedade nem esforço, e que seus livros transbordavam de riso. Como Bion de Borístenes, Menipo de Gádara representou o cinismo semicético e hedonista, voltado para o motejo e para a polêmica. Seus escritos constituíram a base para um tipo de sátira conhecida pelo nome de Sátira menipeia, que exerceu considerável influência sobre a literatura posterior, como se vê especialmente, no âmbito da literatura latina, nas Satirae Menippeae, de Varrão e no Apokolokyntosis, de Sêneca, e, no âmbito da literatura grega, nas obras de Luciano de Samosata. (Ver Referências.)

*Diógenes Laércio: historiador e biógrafo dos antigos filósofos gregos.
} 
Embora não seja considerada um subproduto genuíno da decomposição do diálogo socrático, a menipeia firma-se como o mais importante protótipo da literatura romanesca moderna, depois que o diálogo socrático perdeu força como gênero. A cosmovisão carnavalesca da menipeia tem a ver com o substrato de ruptura e renovação da vida do carnaval transposta para todas as esferas do viver e do criar humanos, o que inclui a literatura e os seus protogêneros.

Há que se fazer aqui, todavia, uma importante distinção entre os conceitos de carnaval e de carnavalização. $O$ primeiro refere-se à tradição corrente desde a Antiguidade das festas de certos períodos do ano, nas quais o homem vivia o próprio espírito do carnaval como uma segunda vida. Já o conceito de carnavalização refere-se à transposição para a literatura e a arte em geral de elementos da cosmovisão carnavalesca, ainda que não ligados diretamente aos festejos do carnaval original.

Dessa forma, por conter elementos de transgressão autorizada, além de outros ligados à cosmovisão carnavalesca, a menipeia carrega em si aspectos peculiares da carnavalização, que reaparecem no romance da pósmodernidade.

É também na menipeia que aparece, pela primeira vez, segundo Bakhtin (2005, p. 116-117, grifo do autor), "[...] aquilo a que podemos chamar de experimentação moral e psicológica, ou seja, a representação de inusitados estados psicológico-morais anormais do homem - toda espécie de loucura ("temática maníaca"), da dupla personalidade, do devaneio incontido, de sonhos extraordinários, de paixões limítrofes com a loucura", tal como acontece nas narrativas em Os Senhores, de Gonçalo M. Tavares.

Ainda segundo o teórico (Idem, p. 113), vestígios da menipeia estão em algumas variedades do romance grego, no romance utópico antigo e na sátira romana. O Asno de ouro, de Apuleio, constitui igualmente uma menipeia.

Esse gênero também influenciou a literatura cristã antiga e a literatura bizantina, chegando a desenvolver-se na Idade Média, no Renascimento, no período da Reforma e na Idade Moderna, estando presente até os dias de hoje, como marca subjacente da literatura europeia em prosa. 
Para Mikhail Bakhtin,

Esse gênero carnavalizado, extraordinariamente flexível e mutável [...], capaz de penetrar em outros gêneros, teve uma importância enorme, até hoje ainda insuficientemente apreciada, no desenvolvimento das literaturas europeias. $\underline{A}$ "sátira menipeia" tornou-se um dos principais veículos e portadores da cosmovisão carnavalesca na literatura até os nossos dias (Ibid., p. 113, grifo do autor, sublinhado nosso).

O objetivo da menipeia é filosófico e ideológico, isto é, à semelhança do diálogo socrático, o gênero busca provocar e experimentar a verdade, revelando-se o homem na profundidade de sua personalidade e de seu pensamento, no intuito de persuadir o Outro, o próprio leitor, com os seus argumentos, mesmo que seja ao apresentar uma verdade "às avessas", como é o caso das personagens de Gonçalo M. Tavares. Na menipeia é maior, entretanto, o peso do elemento cômico, com variações de um autor para outro, estando o gênero livre, segundo Bakhtin,

[...] daquelas limitações histórico-memorialísticas que ainda eram inerentes ao "diálogo socrático" [...], está (a menipeia) livre das lendas e não está presa a quaisquer exigências da verossimilhança externa vital. A menipeia se caracteriza por uma excepcional liberdade de invenção do enredo e filosófica. Isto não cria o menor obstáculo ao fato de os heróis da menipeia serem figuras históricas e lendárias. É possível que em toda a literatura universal não encontremos um gênero mais livre pela invenção e a fantasia do que a menipeia (Ibid., p. 114, grifo do autor, sublinhado nosso).

A finalidade puramente filosófico-ideológica, que é o objetivo do protogênero em questão, não interfere na criação da fantasia e da aventura mais ousada e sem medidas, interiormente motivadas e justificadas, tudo isso no intuito de criar o que Bakhtin denomina de "[...] situações extraordinárias para provocar e experimentar uma ideia filosófica: uma palavra, uma verdade materializada na imagem do sábio que procura essa verdade. Cabe salientar 
que, aqui, a fantasia não serve à materialização positiva da verdade, mas à busca, à provocação e principalmente à experimentação dessa verdade" (Ibid., p. 114 , grifo do autor).

Dessa maneira, para atingir os fins propostos, "[...] os heróis da menipeia sobem aos céus, descem ao inferno, erram por desconhecidos países fantásticos, são colocados em situações extraordinárias reais" (Ibid., p. 114, grifo do autor), assumindo o fantástico, nesse protótipo, o caráter de aventura, seja simbólico ou místico-religioso, sempre com o objetivo ideológico de provocação e experimentação da verdade. A mais absurda fantasia de aventura e a ideia filosófica estão, portanto, unidas orgânica e artisticamente de forma indissolúvel para atingir a meta pretendida.

Bakhtin salienta que se trata da experimentação da ideia da verdade e não de certo caráter humano, social, ou individual. De modo a esclarecer tal aspecto, o autor complementa:

A experimentação de um sábio é a experimentação de sua posição filosófica no mundo e não nos diversos traços do seu caráter, independentes dessa posição. Neste sentido podemos dizer que o conteúdo da menipeia é constituído pelas aventuras da ideia ou da verdade no mundo, seja na Terra, no inferno ou no Olimpo (Ibid., p. 115, grifo do autor, sublinhado nosso).

Outra marcante particularidade da menipeia está na combinação do fantástico livre e do simbolismo, além do elemento místico-religioso, articulado ao que Bakhtin denomina de naturalismo de submundo, de características exageradas e grosseiras (Ibid., p. 115, grifo do autor). Esta última denominação se refere ao submundo humano, constituído pelas camadas mais baixas da sociedade. Quanto à localização, afirma Bakhtin que

As aventuras da verdade na terra ocorrem nas grandes estradas, nos bordéis, nos covis de ladrões, nas tabernas, nas feiras, prisões, orgias eróticas dos cultos secretos, etc. Aqui a ideia não teme o ambiente do submundo nem a lama da vida. $\underline{O}$ homem de ideia - um sábio - se choca com a expressão 
máxima do mal universal, da perversão, baixeza e vulgaridade (Ibid., p. 115, sublinhado nosso).

É de se supor que a linha evolucionária dos protogêneros continue até a contemporaneidade, nos romances e em outras narrativas em prosa, uma vez que esses nunca se extinguem completamente, deixando traços nas narrativas que os sucedem, como é o caso das obras de Gonçalo M. Tavares, em especial, Os Senhores, bem como das de outros autores da pós-modernidade.

Segundo tais pressupostos, os sonhos do senhor Calvino se inserem na concepção da menipeia, a partir da revelação de verdades inusitadas. Do mesmo modo, o gênero está representado no submundo do senhor Henri, que sob o efeito do uso compulsivo do álcool, faz do bar o seu templo. Do mesmo modo, se aplica a temática maníaca às idiossincrasias e distúrbios comportamentais dos senhores Valéry e Juarroz, assim como dos demais senhores.

Em $O$ senhor Brecht (TAVARES, 2005), a exposição da perversidade humana, a crueza das relações interpessoais, as situações sem saída, que revelam tanto a crueldade como a impotência humanas, acabam por demonstrar o que de mais característico a menipeia apresenta como gênero, que se transformou ao longo do tempo, permanecendo em outros gêneros, o que permite que seja identificada e analisada na ficção atual.

Segundo o autor russo, "A ousadia da invenção e do fantástico combinase na menipeia com um excepcional universalismo filosófico e uma extrema capacidade de ver o mundo" (BAKHTIN, 2005, p. 115, grifo do autor), sendo também o gênero das "últimas questões", as mesmas que conduzem a uma nova visão dos indivíduos e à destruição da integridade e da perfeição humanas, terreno no qual dialogam o homem e a sua consciência, como é o caso da entrevista do senhor Breton, sendo ele próprio a representação da relação Eu-Outro nas duas posições simultaneamente.

Há outra característica importante nas narrativas do senhor Brecht, que é também uma forma de the prover segurança. Ao narrar, ele está de posse de algo que é desejado pelo Outro: suas histórias e a "verdade" que elas contêm. 
Tal interesse se revela na sala em que está o senhor Brecht, de início quase vazia, mas que aos poucos vai se enchendo de pessoas desejosas de ouvir as narrativas, não importando o seu grau de terror ou de perversidade.

O homem se configura aí não apenas como um contador de histórias desde sempre, mas, ao mesmo tempo, de um ouvinte que precisa delas. Segundo André Jolles (1976, p. 20), para o homem, é necessário que a imagem de um grupo humano de trabalho pressuponha "[...] ao mesmo tempo, a imagem daqueles que realizam diversos labores no seio dessa comunidade: o camponês, o artesão, o sacerdote, o agricultor, o fabricante e o intérprete. Cultivar, fabricar e interpretar são as três atividades que alicerçam a unidade de um grupo de trabalho".

Desenvolvendo tal ideia, ele prossegue, afirmando que cabe ao camponês produzir a partir do que the oferece a natureza, à qual ele, em contrapartida, confere ordenamento. Assim, "A natureza renova-se nessa vida, mas sem que o curso dos processos naturais seja embaraçado" (Idem, p. 21).

Ao fabricar, o artesão, por sua vez, muda "[...] a ordem das coisas dadas na natureza, de modo tal que elas deixem de ser naturais. Os processos naturais são interrompidos e constantemente perturbados. O que ele renova torna-se verdadeiramente novo" (Ibid., p. 21). Por fim, Jolles conclui:

Para que todo esse trabalho de cultura e fabricação seja possível, entretanto, é necessário, ainda, que um terceiro trabalho, o de interpretação, o dirija constantemente; que todo o trabalho possua um sentido que permita ao homem impor-se; e que a compreensão desse sentido conduza o trabalho, como tal, à sua plena realização. Ou, para manter a nossa terminologia: é necessário adicionar ao trabalho que vincula as coisas a uma ordem, bem como àquele que altera a ordem das coisas, um terceiro trabalho, que é a prescrição da ordem (Ibid., p. 22, sublinhado nosso).

O paralelismo estabelecido por Jolles permite uma reflexão acerca da função do intérprete, que pode ser aí estendida ao narrador, ao que induz à interpretação, no caso, o senhor Brecht. Ao manter viva a narrativa, ao contar 
suas histórias, não importando o seu teor, ele mantém vivo um ordenamento, que é antes de tudo, o da linguagem. Para Jolles,

Todo o trabalho que se realiza por intermédio do camponês, do artesão e do sacerdote é, uma vez mais, realizado através da linguagem. Todo o trabalho feito pelo agricultor, pelo artesão e pelo sacerdote faz parte da vida, passa com ela, renova-se nela ou só possui consistência nela. Mas o trabalho da linguagem confere-lhe nova consistência na própria linguagem (Ibid., p. 24-25, sublinhado nosso).

Completando essa ideia, Jean-François Lyotard afirma:

Pode-se dizer que todos os observadores, seja qual for o cenário que eles proponham para dramatizar e compreender 0 distanciamento entre este estado habitual (coutumier) do saber e aquele que é o seu na idade das ciências, estão de acordo quanto a um fato: a preeminência da forma narrativa na formulação do saber tradicional. [...] Não é preciso reter de tudo isto senão o fato da forma narrativa. O relato é a forma por excelência deste saber, e isto em muitos sentidos (LYOTARD, 1988, p. 37, grifo do autor, sublinhado nosso).

O que buscam os ouvintes do senhor Brecht, cada vez mais numerosos, é o mesmo que buscamos todos nós: dar sentido às coisas, até àquelas que aparentemente não o têm.

Já o senhor Breton, outro narrador-intérprete da realidade humana, foca sua busca no sentido de conscientizar o entrevistado sobre a importância da literatura, e, especificamente da poesia, o que o faz divagar pelos dilemas do poeta, que pode se sentir perdido e assustado em meio à escritura de um verso, como o homem que se assusta diante da vida e não sabe qual caminho tomar.

Tendo, pois, o entrevistador se deslocado por meandros paralelos referentes a medidas físicas de comprimento, ele retoma o raciocínio original, chegando ao ponto que pretende alcançar desde o princípio: ao falar do verso, 
na verdade, o senhor Breton fala da vida e das grandes questões existenciais que afligem o homem, o qual, partindo de aparentes certezas, termina por perdê-las, chegando mais tarde a outras, que também podem desaparecer pelo caminho. Para a personagem,

A questão principal é esta: não apenas no meio da vida o vivo se assusta, também no meio do caminho do seu verso o poeta pode encontrar-se perdido. E se no meio de um verso a escrita olhar para todas as possibilidades e se perceber confusa $\mathrm{e}$ hesitante, o que deve fazer o poeta inquieto? Fechar os olhos e terminar o verso? Fechar a cabeça e terminar o verso? Fechar o coração e terminar o verso? Fechar os dedos? (TAVARES, 2009, p. 49-50, sublinhado nosso).

No caso deste senhor, fica cada vez mais claro para o leitor, ao longo da entrevista, que ele se desloca para um ponto cada vez mais próximo do limiar, em que o adensamento e a complexidade das questões fazem crescer sua angústia. Mais uma vez, emerge aí a menipeia, a qual, no caso do senhor Breton, se revela na busca de respostas para questionamentos que versam sobre temas complexos atinentes ao homem capaz de pensar e indagar.

Todavia, nem sempre há respostas fáceis. Isso confere uma característica de inacabamento, não apenas à personagem, mas também ao enredo, já que não há uma verdade pronta e dada de uma vez por todas. De certo modo, há uma espécie de monologismo da parte do senhor Breton na posição de entrevistador, que prevalece sobre o silêncio e a omissão do entrevistado.

A entrevista representa, pois, em última análise, o autoquestionamento do poeta acerca do processo criativo, trazendo à tona os seus conflitos durante a elaboração da obra, bem como a sua lida difícil com ela, com todas as angústias que permeiam a relação entre criador e criatura, reforçando a ideia de crise, representativa do homem posto diante das grandes questões humanas. 
Outro protogênero está presente nas narrativas de alguns dos senhores, além do romance grego, ou do primeiro tipo. Trata-se do romance do segundo tipo, também chamado de romance de aventuras e costumes, que é assim descrito por Mikhail Bakhtin:

No segundo tipo chama a atenção, em primeiro lugar, a associação do tempo de aventuras com o de costumes [...]. Entretanto, é natural que não se possa falar da associação mecânica (fusão) desses dois tempos. Nessa associação tanto o tempo de aventuras quanto o de costumes transformam-se radicalmente, constituindo um cronotopo completamente novo criado por meio desse romance. É por isso que, aqui, constituise um novo tipo de tempo de aventuras, nitidamente diverso do grego, e um tipo particular de tempo de costumes (BAKHTIN, 1988, p. 234).

Outro fato importante, segundo o autor, é que esse tipo de romance não se desenvolve num tempo biográfico. Para Mikhail Bakhtin,

Ele representa apenas momentos excepcionais da vida humana, completamente fora do comum, bastante efêmeros em comparação com o todo da existência. Entretanto, são esses momentos que determinam tanto a imagem definitiva do próprio homem, como o próprio caráter de toda sua vida subsequente (Idem, p. 238, grifo do autor, sublinhado nosso).

Os protogêneros em questão emergem em narrativas como as dos senhores Walser, Breton e Brecht, como exemplos do protótipo grego do romance de aventuras e costumes.

Segundo Bakhtin, (1988, p. 235), como exemplo de tal protogênero, é possível citar a obra Satíricon, de Petrônio ${ }^{47}$, romance do qual nos chegaram somente fragmentos.

\footnotetext{
${ }^{47}$ Escritor romano que viveu no século I d.C., autor de Satíricon, retrato fiel da sociedade romana do primeiro século da era cristã, é considerado o primeiro romance europeu (Encyclopaedia Britannica.Micropaedia vol. VII. USA: Helen Hemingway Benton, Publisher, 15th ed. 1976, p. 917.) (Tradução livre do verbete feita pela autora.)
} 
Outra obra representativa do romance grego de aventuras e costumes é O asno de ouro, de Apuleio ${ }^{48}$, obra que chegou completa até o presente.

Em ambas há a associação do tempo de aventuras com o de costumes, de acordo com Bakhtin (Idem, p. 235), o que estabelece um novo tipo de cronotopo, diferente do primeiro tipo de romance, no qual não se observa o hiato extratemporal entre dois momentos de uma série da vida real.

No caso da obra de Apuleio, o herói Lúcio passa por várias aventuras marcadas principalmente por dois fatores: a carreira de peregrinações do herói pelo mundo, com sua vida errante de aventuras e provações, o que leva a personagem, finalmente, à metamorfose. Por metamorfose deve-se entender aqui a transformação do homem mais a mudança da sua identidade, o que inclui a parte física, sendo estes os pilares da construção do enredo e da sua organização cronotópica. As provações e as vantagens atravessadas pelo herói ocorrem pelo fato de, em dado momento, e por obra do acaso, ele se ter transformado em asno.

A base dos conceitos de transformação e identidade está assentada sobre a filosofia grega da Antiguidade pré-clássica, por um lado, e pelo envoltório mitológico, por outro. Este último está correlacionado à ideia de transformação originada pelo desenvolvimento religioso, grandemente apoiado nos cultos orientais "com suas formas específicas de metamorfose", segundo Bakhtin (Ibid., p. 235), e, posteriormente, pelas formas primitivas do cristianismo. Também contribui para a idéia de transformação, a ligação da literatura com o folclore, ainda que não tenham chegado até nós conteúdos detalhados de tal folclore popular.

É de mencionar que tal transformação não se dá de forma uniforme e linear, mas aos saltos, o que caracteriza especificamente esta série temporal. O próprio suceder das estações do ano opera mudanças no processo histórico, na própria natureza, e mesmo na vida agrícola, o que nem sempre ocorre de modo retilíneo.

48 Escritor nascido em Madaura, atual Argélia, em torno do ano 124 d.C., morreu provavelmente depois de 170 d.C.. Foi educado em Cartago e Atenas, tendo sido o autor de $\mathbf{0}$ asno de ouro, além de outras peças de ficção, bem como de tratados filosóficos e obras sobre retórica (Idem. Micropaedia v.I. USA: Helen Hemingway Benton, Publisher, 15th ed. 1976, p. 461.) (Tradução livre do verbete feita pela autora.) 
Tais transformações se transferem para esta série temporal da literatura com a inclusão do elemento mágico, que pontua cada metamorfose, transmutando um fenômeno em outro, como é o caso das mudanças sazonais. Bakhtin cita, a título de exemplo desta fase, a obra de Ovídio ${ }^{49}$, Metamorfoses, como representativa do romance do segundo tipo, em que as mudanças começam pela formação do mundo a partir do caos, chegando até a transformação de César em astro.

Esta segunda variante do romance antigo apresenta metamorfoses várias e isoladas, selecionadas a partir da herança mitológica e literária, não ligadas entre si, segundo uma ordem que não reforça a unidade interna da obra. Na descrição de Bakhtin, "Cada metamorfose se autosatisfaz e representa um todo poético fechado" (1988, p. 237), em que o tempo é decomposto em segmentos independentes e mecanicamente ordenados.

$\mathrm{Na}$ obra de Apuleio, a metamorfose apresenta caráter mais privado e mágico, apresentando-se como um modo ao mesmo tempo representativo e interpretativo do destino particular do homem, sem relação com o cosmos ou com a história. Na obra em questão, todo o destino do herói está em jogo nos momentos de crise pelos quais ele passa desde a transformação da personagem Lúcio em asno, suas aventuras neste período, e o seu retorno à forma humana, depois de passar pela provação e a consequente purificação, binômio que constitui outro tipo de metamorfose.

Nesse sentido, a metamorfose se dá em duas direções opostas: o de rebaixamento, quando Lúcio é transformado em asno, e após a ruptura e a crise daí advindas, passando necessariamente por provações e regeneração, até o retorno final à condição humana, e que constitui a metamorfose causada pelo reconhecimento dos erros e da leviandade.

De acordo com Bakhtin (Idem, p. 238), na verdade, o uso do termo metamorfose está ligado tanto à mudança para o mal, inicialmente, o que no caso de Lúcio acontece quando ele se transforma em asno, como também

\footnotetext{
${ }^{49}$ Poeta romano nascido em 43 a.C. e falecido em 17 d.C, autor de Metamorfoses, um de seus mais importantes trabalhos (Encyclopaedia Britannica.Micropaedia vol. VII. USA: Helen Hemingway Benton, Publisher, 15th ed. 1976, p. 640.) (Tradução livre do verbete feita pela autora.)
} 
pode o mesmo processo transformacional ocorrer para o bem, o que no caso da personagem se dá já no final da narrativa, representado por sua volta ao estado humano e à redenção, caracterizando, portanto, o próprio conceito de mudança, em que um indivíduo se transforma em "outro", o que revela duas imagens do mesmo homem.

De fato, em $\mathbf{O}$ asno de ouro, de Apuleio, podem-se observar, de fato, de acordo com o teórico russo, "[...] três imagens da personagem principal: Lúcio antes da transformação em asno, Lúcio-asno, Lúcio purificado e regenerado pelos mistérios" (Ibid., p. 238).

Em comparação com o romance grego do primeiro tipo, é possível notar as principais diferenças entre ambos os tipos de romance no que concerne ao enredo. Em Apuleio, está condensada toda a vida do herói, da infância à morte, dentro de um curso narrativo em que não há uma vida biográfica no seu todo, isto é, apenas um ou dois momentos definem a vida humana e o seu caráter. $O$ herói é determinado por poucas imagens diferentes dele mesmo que, todavia, pertencem ao mesmo homem.

O estágio intermediário, entre o Lúcio homem e o retorno à condição inicial, revela a crise e a purificação, a luta interior e o sofrimento do herói, que levam à ascese, aqui denominada de metamorfose. Para Bakhtin, "A metamorfose tornou-se um modo de interpretação e de representação do destino particular do homem, separado do conjunto cósmico e histórico" (Ibid., p. 237, grifo do autor).

Assim, todo o desenvolvimento desse tipo de romance não ocorre em um tempo biográfico, mas tem lugar somente em momentos excepcionais e transitórios, se comparados com o todo da vida humana. Contudo, são esses instantes marcantes e efêmeros que, segundo Bakhtin, "[...] determinam tanto a imagem definitiva do próprio homem, como o caráter de toda sua vida subsequente" (Ibid., p. 238, grifo do autor).

Tal é o caso das narrativas dos senhores Walser e Breton, cujos embates com as circunstâncias externas e internas geram mudanças importantes, ainda que não constituam metamorfoses propriamente ditas. 
Em relação ao primeiro, o romance do segundo tipo deixa marcas profundas no homem. O que é comum aos dois tipos de romance, o romance grego de aventuras e provações e o romance de aventuras e costumes, é o papel do acaso, determinante da concomitância fortuita e da não concomitância fortuita.

No romance de aventuras e provações, ou do primeiro tipo, como é o caso da obra de Aquiles Tatius - Leucipe e Clitofonte - Leucipe é levado por uma guerra, de cujas razões não se sabe, à casa de Clitofonte. Do mesmo modo, Lúcio toma por engano a caixa do unguento mágico que, em vez de transformá-lo em pássaro, conforme seu desejo original, faz dele um asno. Por outra injunção do acaso, não há em sua casa, no momento, as rosas necessárias à reversão da transformação.

Por outro acaso ainda, na mesma noite, sua casa é invadida por bandidos que roubam o asno. E não apenas o acaso determina os eventos da narrativa, mas também, e principalmente, a volúpia, a leviandade e a curiosidade desmedida do herói, as quais o levam a querer, em uma aventura de feitiçaria, se transformar em pássaro, cabendo somente a ele, portanto, a culpa pelo ocorrido.

O acaso do romance de aventuras e provações, no caso, o de Aquiles Tatius, segundo Bakhtin (Ibid., p. 213 a 221), conduz ao desencadeamento dos eventos que afetam os heróis, Leucipe e Clitofonte, enquanto no romance de Apuleio, Lúcio, curioso e leviano, dispara o acaso e a sequência de fatos que compõem a trama narrativa, criando, assim, a primeira imagem do herói. É o caso do senhor Walser, em que razões não explicadas desviam o curso da vida deste senhor, a partir da chegada dos profissionais

Nesse segundo tipo de romance, o papel do acaso é menor em relação ao primeiro, cabendo a conclusão do romance de metamorfose não ao acaso propriamente dito, mas ao próprio caráter do herói. É o caso do senhor Breton, que voluntariamente parte para o doloroso processo de autoindagação.

No romance de Apuleio, a influência da deusa Ísis constitui também um "feliz acaso", do mesmo modo que o é a influência dos deuses no romance grego. Graças à deusa, que opera como guia de Lúcio e condutora do herói no 
processo de purificação, têm início os meios para a sua transformação, cuja identidade não é confirmada, o que abre finalmente o caminho para a nova imagem do herói regenerado.

Pode-se concluir que se trata de um novo tipo de acaso que comanda as aventuras, não mais um destino cego, mas uma série de eventos que conferem sentido ao enredo, e que consistem, segundo Bakhtin (Ibid., p. 240), em "culpacastigo-redenção-beatitude", levando à transformação final do herói.

Do mesmo modo que no romance grego clássico, como é o caso de Leucipe e Clitofonte, o homem é também um indivíduo privado e isolado, não deixando suas aventuras qualquer marca no mundo ao seu redor, nem estabelecendo qualquer relação com o tempo histórico. A metamorfose sofrida por Lúcio, em $\mathbf{O}$ asno de ouro, é de caráter particular e exterior, independente do mundo, o qual permanece imutável.

O tempo de aventuras fornece a base do romance do segundo tipo, juntamente com o tempo da vida cotidiana. Aí também se insere a metáfora do "caminho da vida", do país natal, da família, sem nada de estrangeiro ou exótico, gerando um cronotopo com base no folclore, cuja principal metáfora é a estrada, com seus signos referentes ao destino.

Também no romance de aventuras e costumes, ou do segundo tipo, o homem se desloca no tempo e no espaço de forma mais concreta, estando estes dois elementos em relação direta com o herói e com o seu destino, configurando um cronotopo mais substancial que o do primeiro tipo.

No caso de Lúcio, a transformação do herói em asno o tira da vida cotidiana, à qual mais tarde ele retorna, baseando-se sua culpa no anseio fútil de escapar ao cotidiano. Espiando a vida do ponto de vista do asno, o herói é levado a refletir privadamente, o que acaba por acrescentar experiência à sua provação, caminho que o conduz, mais tarde, à redenção final.

Além do cronotopo da estrada, onde ocorrem os encontros, como nos romances gregos clássicos, ganha espaço posteriormente a sala de visitas, palco das narrativas do senhor Brecht, do senhor Henri e do senhor Kraus. É neste último cronotopo que passa a ocorrer a maior parte dos encontros de natureza social, diferentemente dos romances da Antiguidade, em que os 
encontros se davam principalmente na "estrada", nos espaços abertos, especialmente os fortuitos; ou no "mundo estrangeiro" (Ibid., p. 352), como são os casos do romance grego clássico do primeiro tipo e do romance de aventuras e costumes.

A superposição dos dois cronotopos cria o ambiente propício de tempo/espaço para que surjam e se esclareçam os nós das intrigas, realizando-se aí também, frequentemente, os desfechos. Bakhtin menciona ainda outros aspectos igualmente essenciais ao motivo do encontro, em que "[...] finalmente ocorrem, o que é particularmente importante, os diálogos que adquirem um significado extraordinário no romance, (e em que) revelam-se os caracteres, as "ideias" e as paixões dos heróis" (Ibid., p. 352, grifo do autor).

É possível considerar que a entrevista do senhor Breton também estabelece conexões com o protogênero representado pelo romance de aventuras e costumes, ou seja, o segundo tipo de romance da Antiguidade, configurando-se como um percurso de provações percorrido pela personagem, tal como acontece também com o senhor Walser.

Segundo Bakhtin (Ibid., p. 234), nesse tipo de romance clássico, tanto o tempo de aventuras quanto 0 de costumes encontram-se radicalmente transformados, sendo que o enredo "[...] não é absolutamente um hiato extratemporal entre dois momentos de uma série da vida real", como se dá na própria entrevista do senhor Breton.

Na obra de Apuleio, assim como na entrevista do senhor Breton, tanto Lúcio como a personagem tavariana, na posição de entrevistado, passam por um período excepcional, o qual, ainda que não tome toda a vida das personagens, muda o curso biográfico, imprimindo "uma marca profunda e indelével no próprio homem e em toda a sua vida" (Ibid., p. 238).

Há que distinguir aqui os motivos que levam as personagens das duas obras ao seu roteiro de sofrimentos. No caso de Lúcio, sua volúpia e curiosidade, portanto, o erro, o levam à provação, enquanto a motivação do senhor Breton é o desejo de autoconhecimento, que pode ser também considerado uma empresa árdua, não se constituindo, todavia, como "erro". 
De acordo com Bakhtin, no caso de Lúcio,

[...] o primeiro e o último nó da cadeia de aventuras estão fora do poder do acaso; em consequência disso, o caráter de toda a cadeia se modifica. Ela se torna eficaz, altera o próprio herói e o seu destino. A série de aventuras vividas pelo herói conduz não à simples confirmação de sua identidade, mas à construção de uma nova imagem do herói purificado e regenerado (Ibid., p. 239-240, sublinhado nosso).

Assim, no protótipo, os eventos extraordinários estão inseridos no curso biográfico da vida da personagem Lúcio, e de modo tão marcante, que acabam por alterar toda a sua vida futura. Prossegue Bakhtin:

Aqui também se contrapõem nitidamente "destino cego", "casualidade funesta", "destino vidente', ou seja, a orientação da deusa que salvou Lúcio. Finalmente, aqui também se revela nitidamente o sentido do "destino cego", cujo poder é limitado pela culpa pessoal de Lúcio, de um lado, e pelo poder do "destino vidente", ou seja, a proteção da deusa, do outro. Esta é a ideia de "castigo fatídico" e de caminho que leva à "verdadeira beatitude", para onde o "destino cego", em sua malícia imprevisível, conduziu Lúcio. Desse modo, toda a série de aventuras é interpretada como um castigo e uma redenção (Ibid., p. 240, grifo do autor, sublinhado nosso).

Tal protótipo está presente nas narrativas dos senhores Henri, Walser e Breton, em que fatos extraordinários mudam, por um período ao menos, as vidas desses senhores.

Outro cronotopo, presente em várias das narrativas de Gonçalo M. Tavares, é aquele identificado por Mikhail Bakhtin como o da pequena cidade, que se funde ao da sala de visitas, marcando o tempo cíclico dos costumes e do cotidiano. Nesse cronotopo não há grandes eventos; apenas o ordinário de uma vida diária que se repete, desgarrada do tempo histórico. É o que caracteriza a vida dos senhores nO Bairro, com raros momentos de quebra de rotina. 
O Bairro e os seus edifícios representam o cenário da pequena comunidade em que vivem, todos próximos, embora isolados, os senhores. Cabe ressaltar que suas rotinas incluem a ideia inseparável do surpreendente e do inusitado, que lhes pontua a vida, e que também consiste em uma repetição de comportamentos "usuais" para seus padrões peculiares, ligados o mais das vezes ao cronotopo da estrada ou do encontro, ou a um tempo/espaço relacionado a este ou a outro cronotopo de caráter público, como é o caso do senhor Henri e do senhor Brecht, vivendo ambos o tempo/espaço da sala de visitas, ou seja, o bar, no caso do primeiro, e a sala, à semelhança de um auditório, no caso do segundo.

Bakhtin assim descreve tal cronotopo:

Dia após dia se repetem os mesmos atos habituais, os mesmos temas de conversa, as mesmas palavras, etc. Durante este tempo, as pessoas comem, bebem, dormem, têm esposas, amantes (não romanescas), fazem intrigas mesquinhas, sentam nas suas lojas ou escritórios, jogam cartas, mexericam. [...]. Os indícios deste tempo são simples, grosseiramente materiais, estão solidamente ligados às particularidades locais: as casinholas $e$ as saletas da cidadezinha, as ruas sonolentas, a poeira e as moscas, os clubes, os bilhares e etc. Aqui o tempo não tem peripécias $\mathrm{e}$ parece quase parado. [...] É um tempo denso, viscoso, que rasteja no espaço (Ibid., p. 353, sublinhado nosso).

Nas narrativas do senhor Brecht é também possível identificar o protótipo do romance grego antigo, especialmente quanto à demanda por grandes espaços, diferentemente dos demais senhores. Ainda para Mikhail Bakhtin,

O tempo de aventuras do tipo grego tem necessidade de uma extensividade espacial abstrata. [...] o mundo do romance grego é cronotópico, mas a ligação entre o espaço e o tempo traz nele um caráter não orgânico, mas puramente técnico (e mecânico). Para que a aventura possa desdobrar-se é preciso espaço, muito espaço. A coincidência fortuita e a não 
coincidência fortuita dos fatos estão indissoluvelmente ligadas ao espaço, medido antes de mais nada pela distância e pela proximidade (e pelos seus diferentes graus) (Ibid., p. 224, grifo do autor, sublinhado nosso).

De acordo com o filósofo da linguagem russo, no romance grego desempenham papel importante elementos composicionais tais como raptos, fuga, perseguição, cativeiros, elementos também presentes nas histórias do senhor Brecht, associados principalmente ao cronotopo do limiar. Nos relatos feitos por este senhor, também não há localização geográfica ou tempo histórico definidos, tal como ocorre no romance grego. Para o autor,

As peripécias aventurosas do romance grego não têm quaisquer ligações substanciais com as particularidades de cada país que figura no romance, com sua estrutura sóciopolítica, sua cultura, sua história. [...]. Por isso todas as aventuras do romance grego possuem poder de transferência: o que ocorre na Babilônia poderia ocorrer no Egito ou em Bizâncio e vice-versa. [...]. Assim, o cronotopo de aventuras caracteriza-se pela ligação técnica e abstrata do espaço e do tempo, pela reversibilidade dos momentos da série temporal e pela sua possibilidade de transferência no espaço (Ibid., p. 224-225, grifo do autor, sublinhado nosso).

Particularidade do cronotopo do encontro, e parte integrante do romance de aventuras, em que todos os eventos, ocorridos ou não, são encadeados segundo uma série temporal infinita e muitas vezes sem qualquer relação causal, o acaso é aí o fator determinante do enredo.

Bakhtin denomina esse tempo de "tempo do acaso", ou das aventuras e provações, em que se dá o tempo da intrusão das forças irracionais na vida humana, ou seja, da "intrusão do destino ('tuké'), dos deuses, dos demônios, dos magos-feiticeiros, [...], dos vilões romanescos, que, na condição de vilões, utilizam como armas a concomitância e a não concomitâncias fortuitas, 'espreitam', 'contemporizam', investem 'de repente' e 'no momento exato'" (Ibid., p. 220, grifo do autor). 
Também no caso do pássaro sucessivamente alvejado da narrativa do senhor Brecht (TAVARES, 2005, p. 19), mencionada anteriormente, ocorre uma coincidência fortuita, um acaso: por algum motivo, estão presentes, no mesmo tempo e lugar, a vítima e o atirador. Trata-se de uma retomada do protogênero constituído pelo romance grego de aventuras, no qual toda a ação e os acontecimentos que a completam, "[...] não se incluem nas séries históricas, de costumes, biográficas e nem na série etária biológico-elementar de tempo" (BAKHTIN, 1988, p. 217).

A grande diferença em relação ao romance grego é que nas narrativas do senhor Brecht, ainda que o acaso tenha um papel importante, há modificação nas vidas das personagens após os acontecimentos, no caso, os encontros, enquanto no protogênero nada muda, isto é, "[...] o mundo permanece tal qual era, biograficamente a vida dos heróis também não se modifica, seus sentimentos permanecem inalterados" (Idem, p. 217).

No romance grego de aventuras, a narrativa principal é composta de pequenos segmentos de que são constituídas as aventuras. Para Bakhtin,

[...] dentro de cada uma delas o tempo está organizado exteriormente, tecnicamente: é importante conseguir fugir; conseguir alcançar, ultrapassar, estar ou não estar justamente no momento dado, no lugar determinado, encontrar-se ou não, etc. [...] Esses segmentos temporais se inserem e se cruzam pelos temas específicos de repente e justamente (Ibid., p. 217, grifo do autor).

Na visão do teórico quanto ao romance grego de aventuras e provações, "Confirma-se tão-somente a identidade de tudo aquilo que havia no início. $O$ tempo de aventuras não deixa rastros" (Ibid., p. 233), como é o caso do senhor Walser, que é no começo como no fim um homem que conserva "grandes expectativas" (TAVARES, 2008, p. 47).

No caso das narrativas do senhor Brecht, os segmentos mencionados, de que são constituídas as aventuras trágicas, apresentam uma conformação das personagens ao seu destino, e não um ultrapassar de dificuldades 
propriamente dito, sendo que os sofrimentos deixam marcas profundas ou levam à morte.

Ainda com relação ao senhor Walser, há a localização inicial em um contexto idílico, no qual a personagem está inserida. De todos os senhores, ele é, possivelmente, o que demonstra maior carência e desejo de convívio com o Outro. É ele também quem mais revela, por meio de suas atitudes e pensamentos, os passos tomados para atingir tal aproximação.

Ocorre com este senhor algo que aproxima a sua narrativa do protótipo grego de aventuras, no qual a iniciativa nunca é das pessoas, as quais constituem meros joguetes do destino, vítimas do acaso, vivendo dentro dos limites da duração de cada aventura, a que não elas deram origem e sobre cuja resolução não têm igualmente nenhum poder.

No protogênero, os momentos do acaso, para o bem ou para o mal, chegam às pessoas por meio de adivinhações, sonhos, auspícios, lendas, pressentimentos e profecias, cabendo aos deuses e ao destino o protagonismo dos eventos. O homem do acaso é, simultaneamente, vítima e beneficiado do destino, conforme afirma Bakhtin (1988, p. 218).

Quanto ao senhor Walser, o acaso diz respeito aos problemas da construção da casa e à correspondente chegada dos especialistas, que interrompem o curso normal da vida da personagem por razões alheias à sua vontade.

Em comparação aos protótipos, é possível observar que os senhores apresentam tanto as características do homem grego clássico, isto é, de indivíduos voltados para fora, como é o caso dos senhores Walser, Henri, Valéry, Kraus e Calvino, como aspectos de introversão mais marcados, como é o caso dos senhores Brecht, Breton e Juarroz.

$\mathrm{Na}$ verdade, são homens da contemporaneidade, com seus conflitos e problemas de relacionamento, o que os coloca dentro dos protótipos e também na contemporaneidade, com as angústias inerentes aos respectivos períodos. Não há como defini-los como indivíduos acabados de uma vez para sempre, já que geralmente não são o que aparentam ser. 
Um dos aspectos importantes quanto aos protogêneros e às narrativas contemporâneas de Tavares "[...] é o entrelaçamento do que é histórico, social e público com o que é particular, e até mesmo puramente privado, de alcova" (Idem, p. 352). Dá-se em Os Senhores a combinação da esfera pessoal e privada, representada pelos ambientes fechados, com o público e o profissional, configurados pelos embates com o Outro.

Assim, pode-se observar nas narrativas tavarianas o que no romance grego clássico mesclava a série histórica com a série biográfica e de costumes, de modo externo e visível, como é o caso da narrativa do senhor Walser, na qual tanto a descrição da natureza que circunda a casa, como a referência explícita aos seus anseios de homem solitário, chegando à desmontagem dos sonhos e da moradia, tudo isso se processa concreta e cronologicamente ordenado na série temporal, diante dos olhos do senhor Walser e do leitor, que acompanham o desenrolar das ações, tal como ocorre no romance grego.

No protótipo representado pelo romance de Aquiles Tatius - Leucipe e Clitofonte -, o início do enredo se dá a partir do primeiro encontro do herói com a heroína, marcado pela paixão que nasce entre eles. O término da trama é "a feliz união dos dois em matrimônio" (Ibid., p. 215). Entre um ponto e outro se desenvolvem as ações de cunho biográfico, que não alteram o caráter inicial da paixão entre o casal. O que importa aqui não são os acontecimentos de ordem biográfica envolvendo a vida dos heróis, mas o que acontece em termos de aventuras e dramas entre o ponto de partida da narrativa e o de sua chegada. Dessa maneira,

Os dois momentos contíguos da vida biográfica e do tempo biográfico são concluídos de forma natural. $\underline{\text { A ruptura, a pausa, }}$ o hiato que surge entre os dois momentos biográficos diretamente contíguos e no qual se constrói justamente todo o romance, não entra na série biográfica temporal, encontra-se fora do tempo biográfico; ele não altera em nada a vida dos heróis, não acrescenta nada a suas vidas. Trata-se exatamente de um hiato extratemporal entre os dois momentos do tempo biográfico (Ibid., p. 216, sublinhado nosso). 
O que na narrativa de Tavares está configurado pelas ações devastadoras dos profissionais dos reparos com seu arsenal de ferramentas e procedimentos agressivos, no romance grego se concretiza por meio de desventuras de múltiplas naturezas: rapto da noiva, discordância dos pais quanto ao casamento, tempestades e naufrágios, salvações miraculosas, ataques de inimigos, guerras, traições imaginárias, falsas acusações e encontros inesperados, prisões, mortes fictícias, disfarces, até o momento final do enlace, em que todos os problemas são resolvidos ou superados (Ibid., p. 214).

No romance grego, o casal finalmente chega à consecução do sonho do casamento, enquanto na narrativa de Tavares o senhor Walser, durante quase todo o tempo e até o final, não vê resolvido o seu quest. Desse modo, à personagem resta apenas manter o sonho a despeito de tudo, como a vítima ingênua e invariavelmente otimista e complacente de uma realidade acidental, a qual, para o momento, parece de difícil solução.

Nas duas obras, não há modificação no caráter ou nos sentimentos das personagens em virtude das desventuras pelas quais passam. No caso do romance de Aquiles Tatius, pode-se afirmar que:

[...] não deve haver nada de essencial entre os dois pontos: o amor do herói e da heroína não desperta desde o início nenhuma dúvida, e esse amor permanece absolutamente inalterável no transcorrer de todo o romance, a castidade deles é preservada, o casamento no final do romance confunde-se naturalmente com o amor dos heróis, apaixonados desde o primeiro encontro no início do romance, exatamente como se entre esses dois momentos nada tivesse acontecido, como se o casamento tivesse sido realizado no dia seguinte ao encontro (Ibid., p. 215-216, grifo do autor, sublinhado nosso).

Quanto ao senhor Walser, apesar da frustração causada pelo Outro invasivo, suas esperanças permanecem. Ao falar sobre o cronotopo do romance grego de aventuras, Bakhtin levanta questionamentos acerca da 
imagem do homem nas circunstâncias têmporo-espaciais em que transcorre a narrativa:

Qual pode ser a imagem do homem nesse tempo de aventuras caracterizado por nós, com sua concomitância fortuita e não concomitância fortuita, com sua ausência absoluta de vestígios, com a excepcional iniciativa do acaso que há nele? É bastante claro que em tal tempo o homem só pode ser absolutamente passivo e absolutamente imutável. [...], tudo simplesmente acontece com o indivíduo. Ele mesmo está privado de qualquer iniciativa. É apenas o sujeito físico da ação. [...] ele é totalmente passivo em sua vida - o "destino" conduz o jogo -, $\underline{\text { mas ele sofre esse jogo do destino. E não apenas sofre, ele se }}$ resguarda e, inalterado, retira desse jogo, de todos os reveses do destino e do acaso, uma absoluta identidade consigo mesmo (Ibid., p. 229, grifo do autor, sublinhado nosso).

Ainda segundo Bakhtin, tal identidade consigo mesmo é o centro organizador da imagem do homem no romance grego de aventuras, com raízes no folclore das sociedades primitivas (Ibid., p. 229). O autor completa: "Por mais empobrecida e desfigurada que esteja a identidade do homem consigo mesmo no romance grego, permanece nele, apesar de tudo, um grão precioso de humanidade popular, a fé herdada no poder indestrutível do homem em sua luta contra a natureza e contra todas as forças inumanas" (Ibid., p. 229).

Dessa forma, o senhor Walser possui não uma complacência meramente indulgente em relação aos especialistas que the invadem e destroem a casa - as forças assim chamadas de "inumanas" por Bakhtin. Sua passividade e aceitação dos percalços contemplam a possibilidade da concretização de seus objetivos, mesmo após tantas dificuldades. Daí ele continuar sendo um homem que ainda tem esperanças, apesar dos problemas.

Outra característica comum ao cronotopo do romance de provações grego e à narrativa em $\mathbf{O}$ senhor Walser (TAVARES, 2008), além da provação como elemento organizador da composição, é o fato de o herói ser um indivíduo particular e privado, afastado que está dos demais senhores que habitam os edifícios dO Bairro. De fato, na narrativa de Tavares e no 
protogênero correspondente, tal traço de isolamento faz com que a personagem não estabeleça, segundo Bakhtin,

[...] qualquer ligação substancial com seu país, sua cidade, seu grupo social, sua linhagem, e até com sua família. Ele não se sente parte do todo social. [...] Ele não tem nenhuma missão nesse mundo. A privatividade e o isolacionismo são traços essenciais da imagem do romance grego [...] (BAKHTIN, 1988, p. 231, sublinhado nosso).

$\mathrm{Na}$ narrativa do senhor Walser, tal como no romance grego, há a questão do estranhamento, em que tudo no enredo é indeterminado e desconhecido, o que constitui a base das coincidências e das não coincidências fortuitas. Há um pequeno grau de familiaridade nos eventos, mas quase tudo é inusitado, sem limites para o poder do acaso e para a rápida sucessão dos fatos, segundo Bakhtin (Idem, p. 217-218), assim como ocorre com aquele senhor a partir do momento da chegada dos profissionais dos reparos, que transforma o seu mundo em palco de incertezas, mazela de todos os lugares e povos, em tempos passados ou recentes. De acordo com Zygmunt Bauman,

Segundo cálculos cautelosos e, se faz diferença, conservadores, a rica Europa conta entre seus cidadãos cerca de três milhões de desabrigados, vinte milhões de expulsos do mercado de trabalho, trinta milhões que vivem abaixo da linha de pobreza. O desvio do projeto da comunidade como defensora do direito universal à vida decente e dignificada para o da promoção do mercado como garantia suficiente da universal oportunidade de auto-enriquecimento aprofunda mais o sofrimento dos novos pobres, a seu mal acrescentando o insulto, interpretando a pobreza com humilhação e com a negação da liberdade do consumidor, agora identificada com a humanidade (BAUMAN, 1998, p. 34, sublinhado nosso).

O que no romance de aventuras grego antigo, ao final de todas as provações, resultava para os heróis na superação das dificuldades e na 
realização dos objetivos originalmente traçados, nas narrativas da contemporaneidade, como é o caso das histórias do senhor Brecht, não há qualquer sinalização de esperança futura. Ainda segundo Bauman,

O sentimento dominante, agora, é a sensação de um novo tipo de incerteza, não limitada à própria sorte e aos dons de uma pessoa, mas igualmente a respeito da futura configuração do mundo, a maneira correta de viver nele e os critérios pelos quais julgar os acertos e erros da maneira de viver. $O$ que também é novo em torno da interpretação pós-moderna da incerteza (em si mesma, não exatamente uma recém-chegada num mundo do passado moderno) é que ela já não é vista como um mero inconveniente temporário, que com o esforço devido possa ser ou abrandado ou inteiramente transposto. $\underline{0}$ mundo pós-moderno está se preparando para a vida sob uma condição de incerteza que é permanente e irredutível (Idem, 1998, p. 32, sublinhado nosso).

A interdependência de pessoas e de países na pós-modernidade distribui por todos as incertezas dos riscos pessoais e globais e, a despeito da tecnologia e dos avanços científicos, ainda caminhamos sobre areia movediça.

Segundo Giddens,

Em sua maioria, [...], situações de risco institucionalmente estruturadas são mais importantes nas sociedades modernas do que nas pré-modernas. Tais sistemas institucionalizados de risco afetam praticamente qualquer um, faça ele ou não parte desses sistemas como "jogador" - mercados competitivos de produtos, de forca de trabalho, de investimentos ou de capitais são os exemplos mais significativos. A diferença entre esses sistemas institucionalizados e outros parâmetros de risco é que eles são constituídos pelo risco, não se tratando de uma situação em que ele é acidental. Ambientes institucionalizados de risco ligam riscos individuais e coletivos de muitas maneiras - as oportunidades individuais de vida, por exemplo, estão agora diretamente amarradas à economia capitalista global. Mas em relação à presente discussão esses ambientes são 
mais importantes pelo que revelam sobre a forma de colonização do futuro (GIDDENS, 2002, p. 111-112, grifo do autor, sublinhado nosso)

Em se tratando dos quadros da realidade, como aparecem nas crônicas do senhor Kraus, repete-se a questão da possibilidade de transferência: a descrição dos desvios dos bastidores da vida política da modernidade tardia poderiam ter lugar em qualquer cidade ou país, sendo os desmandos políticos e a incompetência dos gestores públicos comuns a qualquer lugar, tal qual uma epidemia generalizada, que poderia, até mesmo, ser passível, até certo ponto, de transferência temporal. Há também, neste caso, uma aproximação com o tempo biográfico do romance grego antigo, já que a vida do Chefe, embora não ordenada sequencialmente, descreve episódios que poderiam ser biograficamente incorporados, como as suas características pessoais e comportamentais, e, especialmente, a sua vida pública. Neste caso, o cronotopo da sala de visitas é determinante para revelar o caráter deletério da personagem.

Ainda no caso das crônicas satíricas do jornalista, todos os tipos de conluios políticos do Chefe e dos Auxiliares acontecem diante dos olhos dos leitores das crônicas, inclusive os processos de ocultamento do que não deve ser do conhecimento da opinião pública, assim como o alarde propagandístico do que deve ser revelado de modo a enaltecer a figura do Chefe.

Já nas narrativas do senhor Brecht, o poder do sistema sobre os indivíduos se manifesta sempre que qualquer ameaça, mesmo falsa, ronda o poder instituído, podendo resultar, em alguns países, em aprisionamento ou morte.

A narrativa "Perfeccionismo", revela o rigor de um autoritarismo desmedido, estabelecendo intertexto com o período da divisão das duas Alemanhas, que se seguiu ao final da Segunda Guerra Mundial. Na história do senhor Brecht, "Um pássaro foi abatido a tiro. Acabava de passar a fronteira" (TAVARES, 2005, p. 42). 
Em "Medidas enérgicas" há o relato de que "O governo corrigia os desequilíbrios sociais colocando duas sentinelas em redor de cada pobre" (Idem, p. 35).

Revela-se, nessas narrativas, que tanto a transgressão ou mesmo o risco de que ela ocorra, colocam imediatamente em ação o poder repressivo do poder instituído, cabendo aqui uma reflexão sobre a extensão de tal poder, que paira de diferentes maneiras sobre o homem da contemporaneidade, cujo percurso de vida se dá, segundo Giddens (2002, p. 11), na chamada "cultura do risco".

Para os senhores, assim como para o homem da contemporaneidade, não há terreno seguro. As dificuldades de todos estão ao mesmo tempo localizadas dentro de cada um e externamente, nos confrontos com o Outro. A ideia de que o progresso tecnológico significa maiores condições de bem-estar para grande parte da população do globo nos dias atuais é contrariada por fatos e números, sendo uma das grandes mazelas da contemporaneidade a questão da má distribuição da riqueza dos países, colocando em cheque permanente o binômio tecnologia e bem-estar. 


\section{CONSIDERAÇÕES FINAIS}

Buscar atingir o sentido de uma obra pode parecer, e é, pretensioso. Entretanto, a todo analista e pesquisador cabe, entretanto, levar adiante tal tarefa, sabendo, de antemão, que a sua análise é uma de muitas possibilidades.

Ao analisar a obra Os Senhores, de Gonçalo M. Tavares, nos foi possível perceber que os planos narrativos decorrem das condições cronotópicas, situando circunstancialmente em um todo, tempo/espaço e personagem, que, a partir daí, determinarão a configuração da trama narrativa.

Presentes na obra de Gonçalo M. Tavares, os cronotopos da estrada, do encontro, da sala de visitas e do limiar oferecem, segundo a teoria desenvolvida por Mikhail Bakhtin em sua obra Questões de literatura e de estética: a teoria do romance (1988), os parâmetros excêntricos que configuram falas, movimentos, pensamentos e ações nas várias instâncias narrativas, posicionando as personagens frente aos seus conflitos, dos quais elas tentam inutilmente escapar.

No intuito de conferir sentido à vida, às coisas, ao mundo e a si mesmas, as personagens buscam formas de chegar ao Outro, cada uma à sua maneira, tentando atingir o conforto possível em um mundo hostil, por meio da construção de espaços minimamente estáveis onde possam ser o que são.

Os terrenos movediços das tramas obrigam a que a análise se valha não somente dos recursos literários, mas também de outras áreas do conhecimento, as quais permitem estabelecer pontes metalinguísticas e metafóricas de reconhecimento e aproximação com relação ao objeto de estudo, em que o fragmentário remete para uma nova forma de organização, instigando o leitor e o analista a conferir significado a coisas que aparentemente não o têm.

Desse modo, o cronotopo do bar/sala de visitas, em que se localiza a maior parte do tempo o senhor Henri, permite que ele desenvolva suas particularidades comportamentais de homem verborrágico e beberrão, em um espaço de tensão e ao mesmo tempo de liberalidade, no qual a personagem 
assimila as esferas apolínea e dionisíaca de que fala Nietzsche, ao combinar o seu saber enciclopédico com a sua adição ao absinto.

O senhor Calvino e o senhor Valéry andam pelO Bairro, mas o caminhar rotineiro destes senhores, que aparenta ser recreativo ou sem propósito, é o modo por eles encontrado para chegar ao Outro, o que não ocorre por suas formas idiossincráticas de ser e de estar no mundo. Os cronotopos da estrada e do encontro, conjugados, configuram, assim, a rua, tempo/espaço da busca pela alteridade.

As diferenças que os senhores apresentam em relação às demais pessoas constituem o fator de isolamento, a ruptura na padronização, o atrito que os distancia da convivência e da partilha entre semelhantes, o ruído que os condena ao afastamento em relação ao Outro.

As buscas que empreendem no sentido de encontrar o semelhante complementar se dá a partir da conjunção do tempo/espaço de sua condição de homens deslocados frente ao seu próprio vazio existencial. É na rua, o cronotopo adaptado da estrada, a dimensão têmporo-espacial em que ocorrem os eventuais encontros, nos quais os destinos são decididos, mudando os rumos da existência. Para os senhores, todavia, o desejo utópico não se concretiza.

São eles indivíduos em crise, configurada pelo cronotopo do limiar, o tempo/espaço do impasse, da dúvida, da indecisão. As relações dos senhores com o Outro não se dão em termos da semelhança, mas das diferenças que os excluem, sujeitos descentrados que são.

Ao dar pulinhos na rua, o senhor Valéry quer parecer mais alto, aproximando-se, ao menos na aparência, do padrão estético do Outro. Já os senhores Calvino e Duchamp jogam um jogo sem regras, precisando determiná-las a posteriori para saber quem ganhou. Não há, portanto, encontro possível com a alteridade em um tempo/espaço sem parâmetros ou convenções, e em que não se estabelece, a priori, o contrato.

O senhor Juarroz, solitário e dual, sente grande prazer em estar recolhido ao cronotopo da sua vida interior, tempo/espaço da livre imaginação, 
em que as coisas podem ser como ele deseja, sem interferências externas, e sem as críticas da sua esposa com relação às suas idiossincrasias.

Romântico por excelência, porém sem o perceber, o senhor Calvino torna a sua "janela de abotoar" no Outro possível, o encontro platônico que nunca acontece, mas que ele encena com o mesmo cuidado com que leva a todos os lugares um balão bem cheio preso ao pulso, cercando-o de cuidados, metáfora do Outro frágil, a complementaridade possível, que pode, a qualquer momento, desmanchar-se no ar.

A vida no cronotopo idílico da floresta, junto da mulher amada, cercado de amigos, é o sonho do senhor Walser. A realidade, todavia, o aproxima do Outro indesejável, os profissionais dos reparos, que, ao desmontar a casa, destroem-Ihe o sonho.

O senhor Valéry tem como esposa um "ser ambíguo", uma composição de esfera e cubo: o retilíneo do cubo, a curvatura da esfera, enfim, a combinação ideal em uma esposa que nunca foi vista. Mesmo tendo uma "companheira", o senhor Valéry tem medo: da chuva, de ser feio, de ladrões, de muitas outras coisas. Revela-se aí o indivíduo frágil e só, temeroso e desprotegido, buscando com sua lanterna encontrar algo que ele próprio é incapaz de definir.

O senhor Breton, por sua vez, entrevista a si mesmo, indivíduo cindido em duas personae, confrontadas ambas com perguntas sem respostas, o não diálogo, no tempo/espaço do limiar, da angústia e da dúvida.

Em uma sala quase vazia o senhor Brecht conta suas histórias de dor e perversão, de poder e jugo, cronotopo da sala de visitas que configura a ausência do Outro, a qual ele, ao mesmo tempo, deseja e teme. Ao final, estando a sala cheia, ele se angustia por não enxergar a saída. Novamente, o cronotopo do limiar se sobrepõe aí como o regente da trama.

As crônicas do senhor Kraus satirizam os desmandos políticos. Mas seus leitores não constituem o Outro que ele desejaria que fossem: o eleitor capaz de exercer a crítica sobre os eleitos. A tensão do cronotopo do limiar está sempre presente, tempo/espaço da angústia de quem sabe que prega aos 
ventos. Se o Chefe não ganhar as eleições, outros Chefes virão ocupar o seu lugar, o Outro corrupto e venal a gerir as vidas de todos.

Nessa instância, a partir da análise, das constatações e da interpretação da obra instigante de Gonçalo M. Tavares, começamos a nos reposicionar, incomodados como o senhor Breton, o entrevistado, no tempo/espaço da entrevista. Somos levados a empreender a reflexão crítica sobre a nossa própria condição no mundo, e sobre a condição do Outro, além do papel que cabe à literatura. Sendo antes de tudo arte, a ficção é, todavia, uma estrada de muitos caminhos, e entre eles está o de oferecer ao leitor e ao analista espaço para refletir sobre o homem contemporâneo, seus dilemas e indefinições.

Em certo sentido, somos todos nós, também senhores do senhor Gonçalo M. Tavares, vivendo o tempo do limiar, das contradições, do vazio existencial, do consumo, da mercantilização, dos excluídos de dentro e de fora do sistema, sentindo-nos, muitas vezes, tal como os senhores, estrangeiros sob a própria pele.

Nesse sentido, o papel da ficção, a meu ver, não é dar respostas, mas prover espaços de prazer, de encantamento, de estudo e pesquisa, e de posicionamento crítico-reflexivo sobre o que significa estar vivo no mundo hoje.

À literatura não são pedidas respostas, mas, ainda assim, generosamente, ela nos dá, como faz o senhor Breton, ao dizer que "Um verso tem vida: portanto, altura por fora; e tem ainda mais vida: portanto, altura, por dentro. E se um organismo tem dois mundos, aquele que não se vê é sempre o mais importante [...]" (TAVARES, 2009, p. 49).

Nas palavras de Hannah Arendt:

A privação fundamental dos direitos humanos manifesta-se sobretudo na privação de um lugar no mundo, (um espaço político) que torna significativas as opiniões e efetivas as ações [...]. Tomamos consciência do direito a ter direitos [...] e do direito de pertencer a algum tipo de comunidade organizada, somente quando apareceram milhões de pessoas que haviam perdido esses direitos e que não os podiam reconquistar devido à nova situação global [...]. O homem, segundo parece, pode perder todos os assim chamados Direitos do Homem sem 
perder sua qualidade humana essencial, sua dignidade humana. Somente a perda da comunidade política expulsa-o da humanidade (ARENDT, 1949 apud YOUNG-BRUEHL, 1982, p. 21, sublinhado nosso).

A partir de cenários muitas vezes inusitados e improváveis, o autor estabelece um símile de nonsense dialogístico, contrariando a lógica formal, e que não deve ser analisado com base nas camadas de sentido mais evidentes, mas segundo uma intralógica, estruturada pelo próprio material, tanto no aspecto da forma quanto no do conteúdo, ultrapassando a decodificação ortodoxa e linear.

Gonçalo M. Tavares constrói personagens, cujos cronotopos são arenas multifacetadas, nas quais dialogam e se digladiam pontos de vista convergentes ou opostos, atinentes às várias esferas da vida social, vivendo um cotidiano no qual o desvio e o absurdo constituem a norma, habitando um tempo/espaço conflitante e dual: o da vida e o da arte, ambos tendo como finalidade exprimir uma concepção de mundo "da ordem fora da ordem", em que se tocam simultaneamente elementos tanto da esfera do particular como do universal.

Como uma câmera cinematográfica que gira em todas as direções, expondo o mesmo fato sob vários ângulos, também a visão crítica autoral busca revelar o subjacente, o inferido, aquilo que se esconde sob um enredo aparentemente simples, mas cuja complexidade requer um desmonte de camadas superpostas, de desenho próprio.

O esvaziamento do sentido com base na lógica cartesiana não fecha, todavia, os contextos em si mesmos. Antes, tal esvaziamento promove abertura para múltiplos sentidos, não quaisquer sentidos, mas aqueles que têm como substrato a questão filosófica do homem que contempla a si mesmo, cujos comportamentos se situam dentro de condições-limite da existência.

Para Todorov,

Não há outro caminho para o universal, além do que passa pelo particular e somente aquele que domina uma cultura específica tem oportunidade de ser entendido pelo mundo 
inteiro [...]. Uma coisa é certa: o domínio de uma cultura, pelo menos, é indispensável para o florescimento de todo indivíduo: a aculturação é possível e, com frequência, benéfica: mas a desculturação é uma ameaça (TODOROV, 1991, p. 434-435, sublinhado nosso).

Pequenas histórias encravadas em microrrealidades, que na aparência beiram o inverossímil, quando não o absurdo, constituem a representação da macrorrealidade humana vista sob a perspectiva do homem que a vive, constrói e interpreta, perscrutador de universos interiores e exteriores que, se não são óbvios à primeira vista, nem por isso deixam de ser reais.

Observa-se hoje, da parte de historiadores, sociólogos e estudiosos da contemporaneidade, uma grande dose de pessimismo mesclada ao desejo esperançoso de que as coisas podem ser diferentes, e que um processo de conscientização seria capaz de modificar as circunstâncias perversas que cercam o homem da pós-modernidade, definido por Giddens (2002, p. 193) como política emancipatória. Em suas palavras:

Defino a política emancipatória como uma visão genérica interessada, acima de tudo, em libertar os indivíduos e grupos das limitações que afetam negativamente suas oportunidades de vida. Ela envolve dois elementos principais: o esforço por romper as algemas do passado, permitindo assim uma atitude transformadora em relação ao futuro; e o objetivo de superar a dominação ilegítima de alguns indivíduos e grupos por outros. [‥]. A ruptura com as práticas fixas do passado permite que os homens aumentem o controle social sobre as circunstâncias de suas vidas. [...] Os homens são capazes de, reflexivamente, "usar a história para fazer história" ${ }^{50}$ (Idem, p. 193, grifo do autor, sublinhado nosso).

Tal ideia de uma "utopia possível" é partilhada, metaforicamente, pelo senhor Calvino, que se equilibra no frágil limiar que separa concreto e abstrato. Como em todos os senhores, há nele não apenas o desejo da busca pelo

${ }^{50}$ HABERMAS, Jürgen. Knowledge and human interests. Cambridge: Polity, 1987. 
Outro, a complementaridade do Eu, mas de um conforto partilhado, de um espaço de bem-estar coletivo.

Em "20 sonho de Calvino" (TAVARES, 2007c, p. 11), tal utopia representa o que é difícil de ser alcançado, mas, ainda assim, continua a ser desejado. Na ficção como na vida, tal é a busca humana, que se revela importante por ser busca.

Nessa narrativa, a personagem se depara com uma borboleta que entra em sua sala. Calvino não quer que ela saia, e por isso fecha as janelas. A borboleta pousa em várias coisas improváveis de serem agrupadas em um mesmo tempo/espaço, a não ser por tratar-se de um sonho: primeiro ela faz uma parada na sombra projetada por Calvino, "[...] como se esta fosse uma superfície - um tapete negro finíssimo - e não uma ilusão" (Idem, p. 11).

Em seguida, o inseto "[...] pousa sobre as pernas de uma bela mulher, cuja saia é mínima; aproxima-se depois da mesa e pousa nas páginas abertas do livro de álgebra" (Ibid., p. 11), mais exatamente sobre uma equação de $2^{\circ}$ grau.

A borboleta então parte para a cozinha, onde se dá o susto de Calvino: "Em cima da mesa um bife cru, a borboleta rodeia a carne, mas a mão de Calvino afasta-a a tempo - certas combinações dão azar" (Ibid., p. 11).

A borboleta foge e pousa sobre um quadro. Levanta voo novamente, chegando perto da orelha esquerda de Calvino, que "[...] sente as cores aproximarem-se do seu ouvido e sorri, continua a sorrir, enquanto a borboleta entra, pela orelha, passo a passo, asa a asa, para dentro da cabeça. Está agora lá dentro e esvoaça" (Ibid., p. 11).

O bater delicado das asas faz Calvino se sentir bem, "[...] como se a partir dali já não precisasse de pensar em mais nada, como se o mundo estivesse, finalmente, pensado e resolvido, sem a necessidade de qualquer renúncia humana. Calvino sente-se feliz" (Ibid., p. 11-12).

Do sonho emerge a consciência de que a borboleta, como a utopia, pode estar aqui ou ali, inseto frágil e cobiçado, que persegue e pousa com liberdade sobre as mulheres bonitas, visão concreta do apelo sensual; pousa 
também sobre a ilusão representada pela sombra; sobre os livros, metáfora do conhecimento sempre buscado: o que virá depois? Quem inventa o quê?

Pode a borboleta utópica tentar ainda pousar sobre a matéria que se decompõe, o bife cru, alimento que também a atrai, alquimia de vida e morte; como pode igualmente roçar de leve a arte, o quadro pendurado na sala de Calvino, ou na parede de uma galeria, a encantar os olhos dos que passam. E, por último, pode entrar pela orelha de Calvino, penetrar-lhe o cérebro, permitindo que ele sinta não apenas as suas cores e a sua delicadeza, mas outras tantas coisas que a borboleta o induz a pensar, ou a não pensar: apenas a fruição do que o mundo oferece, como se mais nenhum problema tivesse $o$ homem que resolver.

"Porém, ainda no sonho, Calvino acorda. Uma forte dor de cabeça; e parece não querer passar" (Ibid., p. 12). Para o senhor Calvino, nada de mais: é a realidade de novo, apenas a realidade, o concreto e o material restritivo e contingencial, que todos, incluindo Calvino, esperam um dia dominar:

Pois bem, já ao fim da tarde, e bem dentro de uma rua estreita, Calvino olhou para um lado e para o outro. Eram, em definitivo, duas retas paralelas, e ele, por puro acaso, e sorte, estava no meio delas. Continuou a avançar. Duas retas perfeitamente paralelas, e ele no meio. Que sorte. Duas retas paralelas! Mas a pouco e pouco algo começou a mudar... O senhor Calvino parou então (até porque não podia avançar mais). Havia encontrado o que tantos procuravam: o infinito. Apontou a morada no seu bloco de notas. Ficava no final da rua Sevignon (Ibid., p. 69, sublinhado nosso).

Outros autores contemplam igualmente a utopia possível, além do senhor Calvino. Para Emmanuel Lévinas (1993, p. 69, sublinhado nosso),

[...] a sarabanda das culturas inumeráveis e equivalentes, cada qual se justificando no seu próprio contexto, cria um mundo, certamente, desocidentalizado, mas também um mundo desorientado. Distinguir na significação uma situação que precede a cultura, perceber a linguagem a partir da revelação do Outro - que é ao mesmo tempo o nascimento da moral - no 
olhar do homem visando a um homem precisamente como homem abstrato, sem conotação cultural alguma, na nudez de seu rosto - é retornar de uma maneira nova ao platonismo.

Para o senhor Calvino, todas as possibilidades estão em aberto, não apenas a borboleta que Ihe escapa. É possível, e até mesmo viável, contrariar a geometria euclidiana, segundo a qual, duas retas paralelas só se encontram no infinito, fato que, afinal de contas, pode, quem sabe, significar o fim da busca, já que o ideal almejado pode estar bem ali, no final da Rua Sevignon. 


\section{REFERÊNCIAS}

ANDERSON, Perry. As origens da pós-modernidade. Tradução Marcus Penchel. Rio de Janeiro: Jorge Zahar Editor, 1999.

ARENDT, Hannah. The origins of totalitarianism. New York: Harcourt, Brace \& World, 1973.

A vida do espírito. Tradução Cesar Augusto de Almeida, Antônio Abranches e Helena Martins. Rio de Janeiro: Civilização Brasileira, 2009.

ARISTÓTELES. Retórica. Tradução de Marcelo Silvano Madeira. São Paulo: Editora Rideel, 2007.

AUSTIN, Suzanne A. "A pest in the land: new world epidemics in a global perspective". Santa Fe: University of New Mexico Press, 2003, ISBN 0826328717.

. "The rights of man: what are they?" Modern Review, 3/1, 1949.

Citado em YOUNG-BRUEHL, 1982.

BAKHTIN, Mikhail. Questões de literatura e de estética: a teoria do romance. Tradução Aurora F. Bernadini e equipe. 4. ed. São Paulo: Editora UNESP, 1988.

Tradução M. Lahud e F. Vieira. 9. ed. São Paulo: Hucitec, 1999.

(V. N. Volochinov). Marxismo e filosofia da linguagem.

Estética da criação verbal. Tradução Paulo Bezerra. São Paulo: Martins Fontes, 2003.

Problemas da poética de Dostoiévski. Tradução Paulo Bezerra. 3. ed. Rio de Janeiro e São Paulo: Forense Universitária, 2005.

A cultura popular na Idade Média e no Renascimento: o contexto de François Rabelais. Tradução Yara Frateschi Vieira. 6. ed. São Paulo e Brasília: Hucitec e UnB, 2008. 
BENCHIMOL, Marcio. Apolo e Dionísio: arte, filosofia e crítica da cultura ao primeiro Nietzsche. São Paulo: Annablume e FAPESP, 2002.

BRAIT, Beth (Org.). Bakhtin: conceitos-chave. São Paulo: Contexto, 2008.

BARTHES, Roland. O rumor da língua. Tradução Mario Laranjeira. São Paulo: Martins Fontes, 2004.

BAUMAN, Zygmunt. Ética pós-moderna. Tradução João Rezende Costa. Saõ Paulo: Paulus, 1997.

. O mal-estar da pós-modernidade. Tradução Mauro Gama e Cláudia Martinelli Gama. Rio de Janeiro: Jorge Zahar, 1998.

Bíblia e Hinário Novo Cântico. Tradução João Ferreira de Almeida. 2. ed. Barueri: Sociedade Bíblica do Brasil e Casa Editora Presbiteriana, 1999.

$\mathrm{BOBBIO}$, Norberto. Elogio da serenidade e outros escritos morais. Tradução Marco Aurélio Nogueira. São Paulo: Editora da UNESP, 2000.

BRUNER, Jerome S. O processo da educação. São Paulo: Companhia Editora Nacional, 1997.

CANCLINI, Néstor García. Diferentes, desiguais e desconectados: mapas da interculturalidade. Tradução Luiz Sérgio Henriques. Rio de janeiro: Editora UFRJ, 2005.

CHARAUDEAU, Patrick; MAINGUENEAU, Dominique. Dicionário de análise do discurso. Coord. da tradução: Fabiana Komesu. São Paulo: Contexto, 2004.

CHARAUDEAU, Patrick. Linguagem e discurso: modos de organização. Tradução Angela Corrêa \& Ida Lúcia Machado (vários tradutores). São Paulo: contexto, 2009.

CLARK, Katerina.; HOLQUIST, Michael. Mikhail Bakhtin. Tradução J. Guinsburg. São Paulo: Perspectiva, 2004.

COLLINS Cobuild English language dictionary. London: HarperCollins Publishers, 1993. 
CURTIUS, Ernst Robert. Literatura europeia e Idade Média latina. Tradução Paulo Rónai e Teodoro Cabral. São Paulo: Edusp, 1996.

Dictionary of the English Language, Fourth Edition copyright @2000 by Houghton Mifflin Company. Published by Houghton Mifflin Company, updated in 2009.

EAGLETON, Terry. Teoria da literatura: uma introdução. Tradução Waltensir Dutra. 4. ed. São Paulo: Martins Fontes, 2001.

FARACO, Carlos Alberto. Linguagem \& diálogo: as idéias linguísticas do Círculo de Bakhtin. 2. ed. Curitiba: Criar Edições, 2006.

FERREIRA, Aurélio Buarque de Holanda. Aurélio século XXI: o dicionário da língua portuguesa. 3. ed. Rio de Janeiro: Nova Fronteira, 1999.

FIORIN, J. L. "O romance e a simulação do funcionamento real do discurso". In: BRAIT, B. (Org.). Bakhtin: dialogismo e construção dos sentidos. 2. ed. Campinas: Editora UNICAMP, 2005.

FOUCAULT, Michel. "A linguagem ao infinito", Tel quel, № 15, outono de 1963, p. 44-53.

A arqueologia do saber. Tradução Luiz Felipe Baeta Neves. Rio de Janeiro e São Paulo: Forense Universitária, 2005.

A ordem do discurso: aula inaugural no Collège de France, pronunciada em 2 de dezembro de 1970. Tradução Laura Fraga de Almeida Sampaio. São Paulo: Loyola, 2010.

GIDDENS, Anthony. Modernidade e identidade. Tradução Polity Press. Rio de Janeiro: Jorge Zahar, 2002.

. Mundo em descontrole: o que a globalização está fazendo de nós. Tradução Maria Luiza X. A. Borges. Rio de janeiro e São Paulo: Record, 2011.

HABERMAS, Jürgen. Knowledge and human interests. Cambridge: Polity, 1987. 
HALL, Stuart. A identidade cultural na pós-modernidade. Tradução Tomaz Tadeu da Silva e Guacira Lopes Louro. Rio de Janeiro: DP\&A Editora, 2006.

HUTCHEON, Linda. Uma teoria da paródia. Tradução Teresa Louro Pérez. Rio de Janeiro: Edições 70, 1985.

Poética do pós-modernismo. Tradução Ricardo Cruz. Rio de Janeiro: Imago, 1991.

ISER, Wolfgang. In: EAGLETON, Terry. The act of reading: a theory of aesthetic response. Baltimore: Johns Hopkins University Press, 1978.

JELIN, Elizabeth. "Cidadania e alteridade: o conhecimento da pluralidade". Revista do Patrimônio Histórico e Artístico Nacional. Cidadania №24, 1996.

JOLLES, André. Formas simples. Tradução Álvaro Cabral. São Paulo: Cultrix, 1976.

KAULBACH, Friedrich. "Nietzsche e o pensamento monadológico", 1979. Citado por BENCHIMOL, M. Apolo e Dionísio: arte, filosofia e crítica da cultura ao primeiro Nietzsche. São Paulo: Annablume e FAPESP, 2002.

LÉVINAS, Emmanuel. O humanismo do outro homem. Tradução Pergentino Pivatto (Vários tradutores). Petrópolis: Vozes, 1993.

LYOTARD, Jean-François. 0 pós-moderno. Tradução Ricardo Corrêa Barbosa. Rio de Janeiro: José Olympio Editora, 1988.

MACHADO, Irene A. O romance e a voz. Rio de Janeiro: Imago/FAPESP, 1995.

"Os gêneros e o corpo do acabamento estético". In: BRAIT, B. (Org.). Bakhtin: dialogismo e construção do sentido. 2. ed. rev. Campinas: Editora UNICAMP, 2005.

MAINGUENEAU, Dominique. Novas Tendências em Análise do Discurso. Campinas: Pontes, 1997. 
MARTINS, Nilce Sant'anna. Introdução à estilística. São Paulo: EDUSP, 1989.

MOISÉS, Massaud. Dicionário de termos literários. São Paulo: Cultrix, 2004.

MORA, J. Ferrater. Dicionário de Filosofia. Tomo III. Tradução de Maria Stela Gonçalves et al. São Paulo, Loyola, 2004.

MOTTA, Manoel Barros da (Org.). Michel Foucault - Estética: literatura e pintura, música e cinema. Tradução Inês Autran Dourado Barbosa. Rio de Janeiro e São Paulo: Forense Universitária, 2006.

NIETZSCHE, Friedrich. "Obras incompletas". In: Os Pensadores. Tradução Rubens Rodrigues Torres Filho. São Paulo: Nova Cultural, 1999.

ORLANDI, Eni. Discurso e texto: formulação e circulação dos sentidos. 2. ed. Campinas: Pontes, 2005.

PATRINI, Maria de Lourdes. A renovação do conto: emergência de uma prática oral. São Paulo: Cortez, 2005.

PAULA JÚNIOR, Haroldo O. de. A dimensão dionisíaca do Uno-Primordial nos primeiros escritos de Nietzsche. 2006. 128 f. Dissertação (Mestrado em Filosofia)-Pontifícia Universidade Católica do Paraná, Curitiba, 2006.

PAULSON, Ronald. The fictions of satire. Baltimore: Johns Hopkins University Press, 1967.

PERRONE-MOISÉS, Leyla. "A intertextualidade crítica". Revista Intertextualidades - "Poétique" - parte 3, A obra inacabada. Livraria Almedina. Coimbra, № 27, 1979, p. 217-8.

PIETROFORTE, Antonio Vicente. Análise do texto visual: a construção da imagem. São Paulo: Contexto, 2007.

PONZIO, Augusto. A revolução bakhtiniana. Tradução Valdemir Miotello. São Paulo: Contexto, 2008. 
RESENDE, Viviane de Melo; RAMALHO, Viviane. Análise de discurso crítica. São Paulo: Contexto, 2006.

SANTOS, Boaventura de Sousa. Pela mão de Alice: o social e o político na pós-modernidade. Porto: Afrontamento, 1994.

Cortez, 2002. . (Org.). A globalização e as Ciências Sociais. São Paulo:

. Reconhecer para libertar: os caminhos do cosmopolitismo multicultural. Rio de Janeiro, Civilização Brasileira, 2003.

SPINK, Mary Jane P. (Org.). Práticas discursivas e produção de sentidos no cotidiano: aproximações teóricas e metodológicas. São Paulo: Cortez, 1999.

TAVARES, Gonçalo M. O senhor Valéry. Porto Alegre: Escritos, 2004a.

O senhor Henri. Porto Alegre: Escritos, 2004b.

. O senhor Brecht. Rio de Janeiro: Casa da Palavra, 2005.

. O senhor Juarroz. Rio de Janeiro: Casa da Palavra, 2007a.

. O senhor Kraus. Rio de Janeiro: Casa da Palavra, 2007b.

. O senhor Calvino. Rio de Janeiro: Casa da Palavra, 2007c.

. O senhor Walser. Rio de Janeiro: Casa da Palavra, 2008.

O senhor Breton e a entrevista. Rio de Janeiro: Casa da

Palavra, 2009.

TEZZA, Cristovam. "A construção das vozes no romance". In: BRAIT, B. (Org.). Bakhtin: dialogismo e construção dos sentidos. Campinas: Editora UNICAMP, 2005. 
THOMPSON, J. B. Ideologia e cultura moderna. Petrópolis: Vozes, 1995.

TODOROV, Tzvetan. Poética da prosa. 1. ed. São Paulo: Martins Fontes, 2003.

2004.

As estruturas narrativas. 3. ed. São Paulo: Perspectiva, Perspectiva, 2006.

Introdução à literatura fantástica. 4. ed. São Paulo:

WARREN, Austin; WELLEK, René. Teoria da literatura e metodologia dos estudos literários. Tradução Luis Carlos Borges. São Paulo: Martins Fontes, 2003.

SITES PESQUISADOS:

- Sobre Georg Gadamer:

The European Graduate School - Graduate \& Postgraduate studies. Disponível em: http://www.egs.edu/library/hans-georg-gadamer/biography/ Acesso em: 07 out. 2011.

- Entrevistas de Gonçalo M. Tavares:

Entrevista concedida à revista Círculo dos Leitores. Revista online.

Disponível em:

http://www.circuloleitores.pt/cl/artigofree.asp?cod artigo=107981

Acesso em: 27 jun. 2009.

Entrevista concedida à Editora Caminho online.

Disponível em: www.editorialcaminho.pt 2005

Acesso em: 13 out. 2011.

Entrevista concedida a Veja.

Disponível em:

http://veja.abril.com.br/blog/meus-livros/entrevista/goncalo-m-tavares-e-a-

gloria-do-portugues/

Acesso em: 04 jan. 2012. 
- Sobre o absinto:

Disponível em:

http://ntp.niehs.nih.gov . Acesso em: 25/9/11. Tradução livre da autora.

Acesso em: 25 set. 2011.

Disponível em:

http://revistaadega.uol.com.br/edicoes/7/artigo16707-1.asp

Acesso em: 07 jan. 2012.

Consultoria: www.absinthe.com.br

Disponível em:

http://blogs.estadao.com.br/arquivo/2011/06/16/fada-verde-tinha-seus-diascontados-na-francal

Acesso em: 07 jan. 2012. 
ANEXO 1

\section{O bairkno}

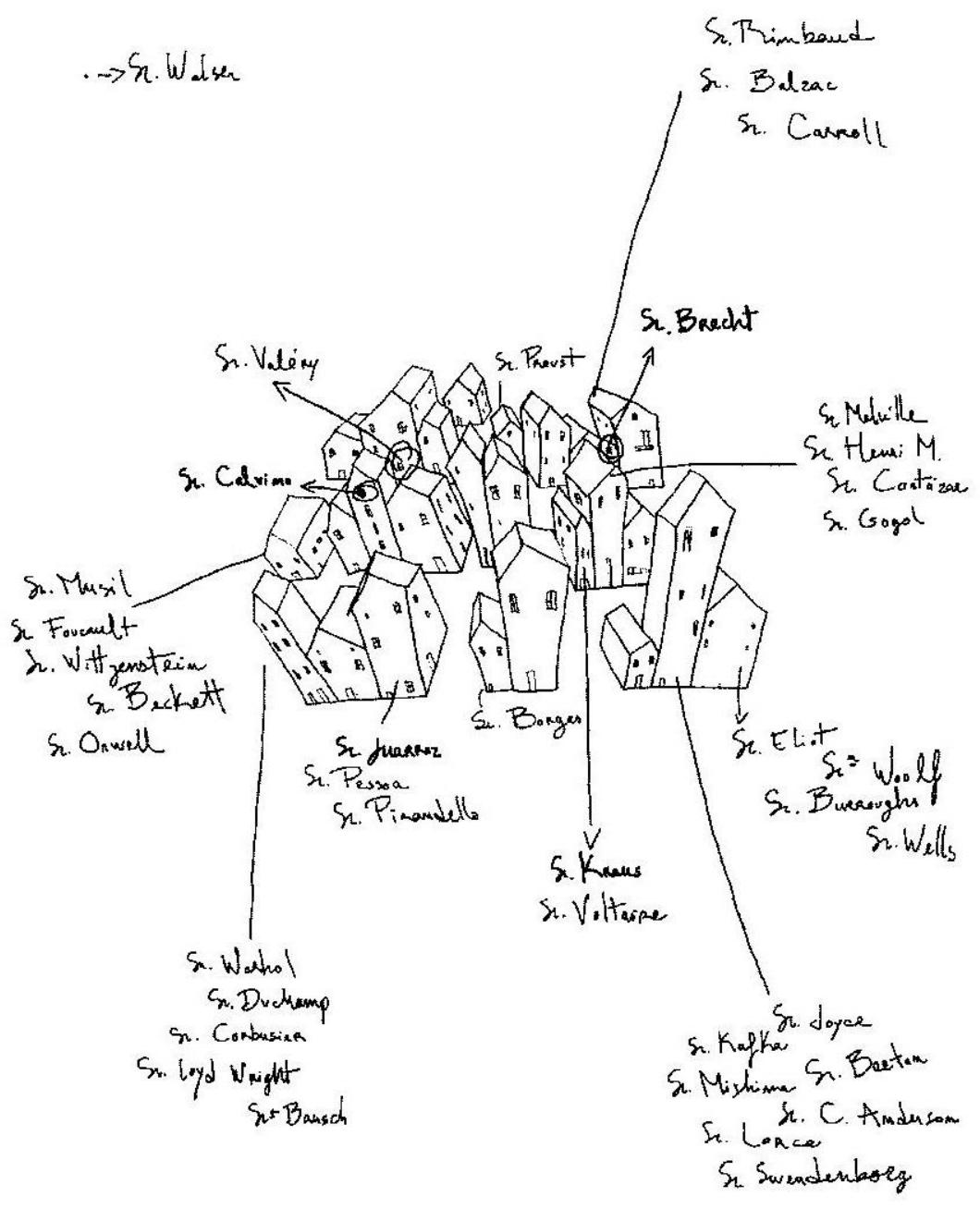

Ilustração de Rachel Caiano 


\section{ANEXO 2}

TRÊS ENTREVISTAS DE GONÇALO M. TAVARES

\section{Entrevista concedida a Entrelivros ${ }^{51}$}

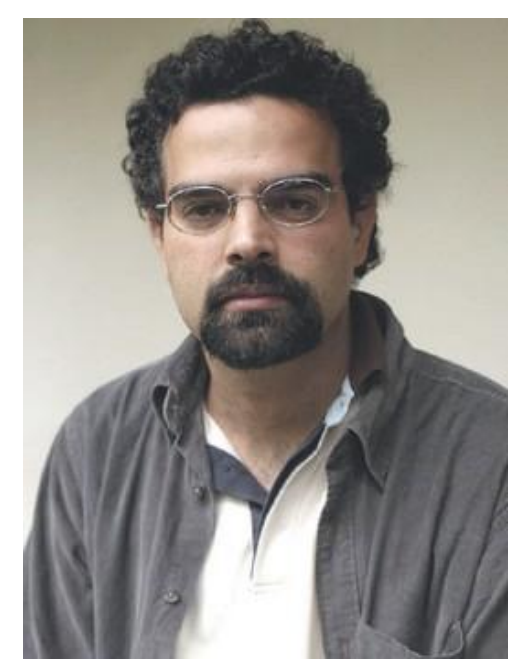

Gonçalo M. Tavares é um abalo sísmico no panorama da literatura portuguesa atual. Após estrear em 2001 com Livro da dança, publicaria no ano seguinte nada menos do que outros quatro títulos de poesia, teatro e ficção. $\mathrm{Na}$ época, foi recebido pelo decano ensaísta Eduardo Prado Coelho como já "um dos maiores poetas para o século XXI". O escritor português nascido em Angola tem cumprido a sina: em tão pouco tempo, lançou 21 livros em 12 países e é bem recebido pela crítica.

No Brasil sua fulminante trajetória não é diferente: apenas nos últimos meses saíram Um homem: Klaus Klump (Companhia das Letras), seu primeiro romance, além de $\mathbf{O}$ senhor Juarroz, $\mathbf{O}$ senhor Kraus e $\mathbf{O}$ senhor Calvino, habitantes da série O Bairro (Casa da Palavra) que vieram se juntar a O senhor Brecht, publicado em 2005. Tamanha proficiência é coroada agora com a seleção deste último e do romance Jerusalém ao prêmio Portugal Telecom.

\footnotetext{
${ }^{51}$ Foto disponível em: www.uol.com.br, extraída do site da entrevista. (Ver Referências.)
} 
Autor de obra caracterizada não somente pela exuberância criativa, mas também por rigorosos jogos de lógica que misturam poesia e filosofia sem nunca deixar de divertir o leitor, Gonçalo M.Tavares revela a Entrelivros alguns de seus enigmas. Livros, para ele, têm principalmente a missão de aumentar a lucidez.

Entrelivros: Por que livros pretos?

Gonçalo M. Tavares: Essa designação foi uma designação quase óbvia, no início, porque tinha ver, em primeiro lugar com as capas pretas e é evidente que remete também para um certo ambiente pesado. E se calhar foi também um contraponto com "O Bairro". Digamos que o nome, mais do que livros pretos, neste momento o que me pareceu evidente, porque as coisas vão aparecendo aos poucos, é que o nome que eu dou à tetralogia é "O Reino". É como se fosse o título de um romance único, realmente composto por quatro romances.

Entrelivros: Então surgiram-te primeiro as capas pretas ou pensaste primeiro no nome livros pretos?

GMT: Já não sei bem. Acho que foi uma coisa quase simultânea. Aquelas capas apareceram naturalmente. Daqui a uns tempos talvez apareça uma reedição com outro tipo de capas. Ou seja, o título não remete só para a capa, até porque eu incluo nos livros pretos o Água, Cão, Cavalo, Cabeça. Portanto, a capa é apenas um sinal, mas não é o mais importante.

Entrelivros: Interessa-te explorar esse lado negro da nossa espécie?

GMT: Interessa-me, tal como interessa explorar outros lados. Por exemplo, se pensarmos no Senhor Valéry ou no Senhor Calvino, ou por exemplo nas Breves notas sobre o medo, acho que são outros lados que são explorados. Por vezes exploro a lógica, por vezes exploro a ideia de paradoxo. Aqui realmente trata-se de... eu gosto da palavra investigar. Portanto, acho que é mais a ideia de tentar perceber, não é encontrar soluções nem respostas, mas tentar perceber melhor como é que funciona o homem em circunstâncias, por vezes, de limite. Neste último romance, Aprender a rezar na Era da Técnica, isso está muito evidente. Procuro perceber como é que um homem se pode comportar perante, por exemplo, o poder extremo ou perante a doença. E é isso que me interessa: tentar perceber melhor. Ou seja, é um pouco como se os livros permitissem, espero eu, que um leitor consiga perceber melhor o problema. Não encontre uma solução, porque para esses problemas não há soluções, mas que perceba melhor o homem e o que o homem pode fazer em determinadas circunstâncias. 
GMT: É fundamental não romantizar a loucura. A loucura concreta é uma coisa muito dura, muito violenta.

Entrelivros: Sim. Por exemplo Lenz, no último romance, tem uma ideia um pouco romântica, tem uma grande atraç̧ão pela loucura e pelos loucos.

GMT: Exacto. Mas se pensarmos no Jerusalém é evidente que os loucos são portadores de um sofrimento muito forte. Agora, por vezes, como no Jerusalém, a marca da maior violência vem das pessoas mais racionais, como o director do hospício. Provavelmente as coisas mais violentas, ou muitas das coisas violentas, vêm daí e não propriamente dos loucos. Ou seja, respondendo um pouco à pergunta, muitas vezes a violência não vem das pessoas que perderam a razão mas, às vezes, até estranhamente das pessoas que têm o total controlo da razão.

Entrelivros: E será que podemos dizer que todos, ou quase todos, os protagonistas desta tetralogia são loucos? Isto é, há os que são vistos como loucos - como Mylia e Ernst - mas todos os outros, os mais racionais, têm uma racionalidade que está na fronteira entre a racionalidade e a loucura.

GMT: Não sei, tenho algumas dúvidas. Eu acho que é perigoso associarmos 0 mal, ou a possibilidade de fazer o mal, com a perda da razão. Quer seja, é evidente, nos loucos quer seja noutras pessoas, a razão levada ao extremo. Porque, precisamente, o que me parece importante é também estarmos um bocado atentos à racionalidade, porque a racionalidade é ela própria portadora de violência. Ou seja, acho que não se deve associar uma pessoa racional a uma pessoa bondosa. A razão e o bem não estão associados. Aliás, claramente o grande drama do século XX, se pensarmos na $2^{\underline{a}}$ Guerra, no Holocausto, é que não há uma dissociação, bem pelo contrário, entre razão e violência extrema. Pelo contrário, razão e violência extrema estão muito ligadas. Portanto, eu diria que esses protagonistas são protagonistas muito humanos, no sentido em que não são, espero eu, ingenuamente pintados como seres magníficos e como seres humanos bondosos em qualquer situação. Até porque eu acho que todos nós somos muito condicionados pelo que nos vai acontecendo. E, portanto, a proclamação de que eu sou um homem bom, independentemente do que aconteça, é uma proclamação perigosa. Quando as circunstâncias mudam, nós podemos fazer actos de que nos envergonharemos mais

tarde.

Entrelivros: O protagonista de Aprender a rezar na Era da Técnica faz uma distinção interessante entre a bondade e a competência técnica. Ele diz que por ser um bom médico e salvar vidas não significa que seja boa pessoa. $O$ que é que é mais importante: ser bom ou ser competente?

GMT: Eu penso que isso é realmente um dos temas principais do romance. $O$ que me parece é que há uma transferência, que não é dos últimos anos, é das últimas décadas ou eventualmente do último século e meio. É difícil precisar quando é que essas coisas começam. Mas é uma transferência da questão da bondade para a questão da competência. É evidente que para mim, neste momento, talvez seja claro e não seja muito injusto se eu disser que a maior 
parte das pessoas tem mais vergonha de, por exemplo, não dominar o último programa do Windows do que de mentirem. Ou seja, as questões morais começaram a diluir-se um pouco nas questões técnicas e, portanto, há claramente uma transformação de valores, onde a técnica começa a dominar. E a técnica a todos os níveis, não apenas técnica de maquinarias, realmente a técnica de competências. $E$ nesse aspecto, para mim é claro que a moral do século XXI é uma moral completamente diferente do que era a moral, por exemplo, clássica. É evidente que há uma alteração.

Entrelivros: É necessário aprender a rezar na era da técnica?

GMT: Isso é uma pergunta interessante. O título do livro já suscitou várias interpretações e isso agrada-me imenso. $E$ por isso é que eu tento nunca dar uma interpretação definitiva de uma passagem do livro ou de um título, porque, para já, não há interpretações definitivas. Cada leitor tem a sua interpretação. Mas uma leitura pode ser essa, de que é necessário um contraponto para a evolução da técnica e que esse contraponto possa ser o carácter religioso. Se calhar também se pode pensar o que é isto de rezar. Será que no século XXI, no ano de 2008, fará sentido rezarmos da mesma maneira do que rezávamos há cem anos, ou há duzentos, ou há dois mil anos? É uma coisa que para mim é muito clara. Neste momento, a nossa paisagem é completamente diferente, se pensarmos em há dois mil anos então... Temos uma paisagem em que a técnica e as máquinas estão por todo o lado. Portanto, nesta nova paisagem da técnica, em primeiro lugar, será que faz sentido rezar? E depois, se faz sentido, que tipo de oração ou que tipo de reza faz sentido? Será que faz sentido rezarmos exactamente da mesma maneira? Isso é uma questão que se calhar este romance coloca. E provavelmente a forma de rezar do protagonista, do Lenz Buchmann, pode dar a ideia de que ele não reza, mas também podemos interpretar como uma outra forma de oração. Eventualmente a cena final pode ser interpretada dessa forma. Portanto, não sei se é preciso rezar ou não, o que é preciso é pensarmos se faz sentido rezar e se faz sentido continuarmos a rezar da mesma maneira. Talvez este livro ponha algumas questões sobre isso.

Entrelivros: Este médico de Aprender a rezar na Era da Técnica é muito racional, ao passo que o médico de Jerusalém era um médico muito crente. Tinha uma visão muito distante da dos restantes médicos. Como é que podem coabitar a ciência e a religião?

GMT: Tradicionalmente há a tendência para as colocar quase como se fossem dois inimigos, a ciência e a religião. A ciência como espaço que vai tirando bases e fundamentos religiosos através de novas investigações. Eu acho que podemos não ter esta visão dualista entre ciência e religião. Para já, os próprios métodos científicos pressupõem internamente uma espécie de crença. Aliás, há vários autores que falaram sobre esta ideia: a ciência, dentro dela própria, tem uma crença nos seus métodos. Uma crença que não é uma crença religiosa, não é uma crença num deus ou em vários deuses, mas é uma crença nos seus métodos. Portanto, acredita que os seus métodos conseguem chegar à verdade. $\mathrm{E}$ isto é, de certa maneira, uma crença. Por outro lado, há inúmeros casos de cientistas crentes. Cientistas de grande qualidade extremamente 
crentes. Portanto, não é uma coisa que invalide a outra. Penso, aliás, que há uma tendência mais recente... Há várias tendências. Há uma tendência antireligiosa, há uma tendência científica que se aproxima da religião. Há tantas tendências e tão diferentes que é difícil dizermos que a ciência vive sem religião ou que a religião se afasta da ciência, ou vice-versa. Há uma série de movimentos que estão a aparecer. O que só mostra que, realmente, a religião é uma coisa que não se pode eliminar das vidas. Isso para mim é muito claro. Mesmo quando uma pessoa combate a religião, é sinal de que o carácter religioso continua presente e tem importância. Porque nós não combatemos algo que não tem importância. A única conclusão que eu tiro é que mesmo com a evolução científica prodigiosa dos últimos tempos, a religião continua sempre, qualquer que ela seja, a ter o seu espaço.

Entrelivros: Interessas-te muito por ciência? É que a tua própria escrita tem certos momentos de rigor científico, com encadeamentos lógicos que lembram o pensamento científico.

GMT: Sim. Isso é interessante. Interesso-me bastante por ciência. E até talvez, em próximos livros, esse cruzamento entre ciência e literatura apareça mais, porque, realmente, cada vez me interesso mais por ciência. $\mathrm{O}$ que eu penso em termos de interesses é que tudo pode ser interessante, se nós tivermos um olhar não preconceituoso. E gosto da ideia de mistura. Não gosto da ideia de que uma área vive isolada das outras. A literatura não pode viver isolada da ciência, da própria religião, etc. Eu leio muitos livros de ciência, é algo que me interessa bastante e acho que, provavelmente, vai tomar mais importância, para mim, no futuro.

Entrelivros: $\mathrm{E}$ achas que a ciência pode explicar tudo? Por exemplo, a personagem do Thomas Busbeck (em Jerusalém) queria estudar o horror sobre massas, de modo a chegar a conclusões científicas, como a frequência com que acontecem. É possível explicar cientificamente algo deste género?

GMT: Se a ciência pode explicar tudo? Não. Eu acho que a presença da religião e a presença da crença - e aliás nos últimos tempos o aumento da importância da crença religiosa - mostra que a ciência não pode explicar tudo. Se pudesse explicar tudo, todos esses impulsos religiosos se apagariam. E há perguntas básicas, quase essenciais, que a ciência ainda não pode responder. $\mathrm{E}$ se calhar é por isso que a crença religiosa continua muito intensa.

Entrelivros: Há pouco falávamos do facto de vivermos numa era de técnica e de ciência. Será que a própria espécie humana caminha para uma mecanização? Joseph Walser (em A máquina de Joseph Walser) pode ser visto como uma máquina. E quando perde um dedo, é uma máquina que perde uma peça.

É interessante essa interpretação. Eu acho que sim, por um novo conjunto de vidas que quase se transformam em vidas mecânicas, infelizmente. Acho que hoje, no século $X X I$, como no século $X I X, X V I I I$ e até mesmo antes, isso acontece, se considerarmos o mecânico como algo que se repete: fazer sempre a mesma coisa. Não sei se há uma relação entre o aparecimento de mais máquinas, mais tecnologia e uma mecanização do homem. Na origem do 
aparecimento das máquinas havia uma espécie de utopia, que já foi abatida, de que as máquinas iriam libertar a criatividade do homem. O [Antonin] Artaud fala um bocado disso, diz que com o aparecimento das máquinas os homens poderiam dançar. O Artaud e outros autores falam dessa ideia: eu quero ser uma máquina em determinadas coisas, para poder dançar, festejar, criar, e todas as minhas funções básicas poderem ser satisfeitas com uma máquina. Há um texto muito importante do [Gilles] Deleuze, que pegou nessa ideia do Artaud, que defende a ideia de que um corpo sem órgãos - portanto, sem estômago, sem necessidade de se alimentar - muito próximo de uma máquina, sem necessidades orgânicas, seria um corpo mais livre, porque as necessidades orgânicas, se nós pensarmos, são as necessidade que, de certa maneira, nos escravizam. Se nós não precisássemos de comer, provavelmente não precisaríamos de fazer trabalhos de que não gostamos. Portanto, há um conjunto de necessidades orgânicas biológicas que nos mecanizam, num certo sentido. E o que pode parecer estranho, era o que defendiam alguns autores desta linha, é que se nós não tivéssemos necessidades orgânicas podíamos ser mais livres e mais criativos. Acho que esta é uma linha possível. O que me parece é que nós temos de lidar com as máquinas, percebendo que a mesma máquina nos pode escravizar, nós podemos ser escravos da máquina, ou nós podemos aproveitar a máquina para fazer qualquer coisa de interessante e pessoal. Acho que tem muito mais a ver com a forma como nós lidamos com as máquinas. Apesar de haver, julgo eu, mecanismos que transmitem mais passividade do que outros. Por exemplo, eu acho que a televisão é um transmissor de passividade. É muito difícil ser activo frente a uma televisão. Enquanto que se pensarmos, por exemplo, na Internet, apesar de tudo, eu acho que a pessoa pode ser muito mais activa, muito mais criativa, em frente a um computador. Mas claro que isto não são regras. Há pessoas que ficam totalmente passivas diante de um computador, e diante da Internet, e há pessoas que podem conseguir através de um programa de televisão estar, ao mesmo tempo, a provocar na sua cabeça alguma coisa de interessante. Tem muito a ver com a forma como nós enfrentamos o objecto técnico.

Entrelivros: $O$ corpo e a mente são dois elementos muito explorados na tua obra. À partida, seríamos levados a pensar que a mente tem poder sobre 0 corpo e pode dar ordens ao corpo. Mas às vezes, nas tuas personagens, parece que acontece o contrário: o corpo é que molda a mente. Por exemplo, Joseph Walser quando perde um dedo ou as várias personagens com deficiências físicas. De facto, quem manda em quem: o corpo ou a mente?

GMT: Eu diria logo que talvez não exista uma separação. Se quisermos agora definir mente, provavelmente temos de passar por definições corporais. Tentar perceber o que é a mente, em oposição ao corpo, pode ser difícil, porque se pensarmos no cérebro, o cérebro é corpo. As funções do cérebro são funções corporais. Tal como a função de levantar um braço. A função de pensar, é evidente que não tem o mesmo tom, mas é uma função que tem algumas parecenças. É óbvio que tem muitas diferenças, mas há semelhanças com o acto de, por exemplo, levantar a mão. O acto de pensar é, claramente, um acto único e nenhum outro acto corporal é semelhante a este. Mas é evidente que nós pensamos de diferentes maneiras. Ao movimentarmo-nos, estamos, certa maneira, a pensar. São pensamentos quase instantâneos. Por exemplo, 
quando nós fechamos os olhos, diante de uma luz forte, os nossos olhos, de certa maneira, estão a pensar, naquele momento. Eu diria que talvez não exista uma separação entre mente e corpo. Agora, é evidente que essas alterações corporais, como esse exemplo do Joseph Walser quando perde um dedo, essas alterações a um nível brutal de perda de uma parte do corpo são alterações de tal forma significativas que toda a forma de pensar se altera. Portanto, há aqui uma relação. Mas acho que não há uma distinção material. É o mesmo tipo de material.

Entrelivros: A guerra interessa-te enquanto pano de fundo para a verdade?

GMT: Em Um homem: Klaus Klump diz-se que o medo e a fome são exercícios para treinar a verdade. E a guerra traz o medo e traz a fome. A guerra, como provavelmente todos os momentos limite, é um desses momentos em que as pessoas são levadas até pontos de tal forma extremos que têm de fazer acções que não são normais. Há qualquer, não sei se verdade, mas qualquer coisa que estava escondida nos homens que tem de vir à superfície porque está numa situação limite. E é evidente que só situações como a guerra e outras é que fazem com que essas coisas venham ao de cima. Comportamentos que podem estar escondidos durante quarenta anos. Agora, se isso é a verdade do homem ou não, não sei. O que os personagens fazem ou o que livros dizem não é, necessariamente, a minha opinião. Mas é interessante agora pensando sobre isso, não sei se a verdade é a normalidade ou se aparece apenas nos momentos excepção. Julgo que tanto uma hipótese como a outra são aceitáveis e argumentáveis. Mas o que eu acho claro é que sem esses momentos limite não conseguimos tornar visíveis certas coisas.

Entrelivros: Nesse passo de Um homem: Klaus Klump diz-se também que estar apaixonado é outro exercício para treinar a verdade. Porém, não é uma situação tão extrema como o medo ou a fome. Será que podemos de facto juntá-los?

GMT: Aqueles momentos de paixão extrema são também, de certa maneira, momentos que saem da normalidade. Ou seja, há comportamentos que nós temos nessas alturas que nos dias comuns, digamos assim, não temos. Há uma espécie de loucura momentânea. Aliás, há quem defina a paixão como uma perda temporária da racionalidade absoluta. Uma espécie de loucura circunstancial ou loucura efémera. Em termos práticos, há coisas concretas que se podem fazer nos momentos em que a pessoa está completamente apaixonada, que não faria noutra situação. E portanto, pode haver alguma ponte para as situações limite, embora sejam muito mais brutais e muito mais fortes, como o medo de morrer. Mas pode haver alguma ponte nesse aspecto.

Entrelivros: A paixão ou amor entre duas pessoas, na ideia convencional que dele se tem, não aparece muito na tua obra. Será que é o estado limite, sobre o qual é mais difícil escrever?

GMT: Eu acho que aparece em alguns momentos. Por exemplo, eu diria que a paixão ou o amor aparece, se calhar de uma forma não muito evidente, mas aparece e tem muita importância no Jerusalém. Há ali uma relação amorosa 
da Mylia e uma relação de sacrifício. No final ela, de certa maneira, sacrificase. Portanto, é uma personagem ligada à paixão. Aparece também no Aprender a rezar na Era da Técnica, sendo, é evidente, misturada com vários tipos de perversidade. A personagem Julia, por exemplo, hostiliza um avanço do Lenz Buchmann no momento em que este está forte, não correspondendo à paixão ou aos avanços de Lenz, e depois mais tarde, quando ele está doente, ela aproxima-se sexualmente, digamos, do homem fraco, que naquele caso está em decadência. Isso é um pormenor, mas julgo que tem muita força e muita importância no romance. Ou seja, é alguém que se aproxima do outro, quando o outro está fraco. Isto é uma forma de amor, de certa maneira. Claro que não é aquele amor padronizado em que um casal é feliz para sempre. Não é isso, mas há nos romances momentos de amor e de dedicação. Há vários tipos de amor entre casais, mas há também amor entre pais e filhos, etc. Por exemplo, podemos condenar o tom deste amor, mas há claramente uma relação amorosa entre o Lenz Buchmann e o pai. É uma relação de amor e dedicação que marca quase todo o livro. Desde o início, naquela primeira cena, até ao final, há uma quase reverência absoluta ao pai. E podemos utilizar a palavra amor para essa paixão de Lenz pelo pai. Claro que não é um amor com consequências muito agradáveis, mas nem sempre as relações amorosas têm consequências agradáveis para as outras pessoas. Portanto, eu acho que há situações de paixão e amor nos romances. Talvez não seja uma coisa sempre clara, sempre pacífica, porque eu acho que essas situações podem ser um bocado artificiais. Eu acredito que nestes livros o amor aparece em pequenos passos e vem do escuro, da perversidade. Portanto, esses pequenos actos e gestos de amor, paixão e dedicação ganham uma maior força, mas são sempre coisas de pormenor.

Entrelivros: Este Reino a que a tetralogia reporta, pelos nomes das personagens, tende a situar-se na Europa Central e de Leste. Por outro lado, a temática em si é universal. Podemos situar a acção em qualquer parte do mundo. Há a intenção de a situar em algum local?

GMT: Não, não há. Por isso mesmo é que nunca há referência a um espaço concreto. Os nomes das personagens surgiram naturalmente. Quando comecei a escrever o primeiro, Um homem: Klaus Klump, naturalmente, ao começar a escrever com aquele ambiente, apareceram aqueles nomes. Portanto, os nomes das personagens são coisas muito pouco explicáveis. A certa altura, quase que tinham de ser aqueles nomes e não outros, embora por vezes eu hesite em dar um nome ou outro a uma personagem. Mas realmente como disseste, não quero situar em lado nenhum. Infelizmente, aquele ambiente dos dois primeiros romances de guerra e perversidade, é um ambiente que pode ser colocado em vários pontos do mundo. Já houve pessoas que me disseram que podiam situar isto na Europa Central, outros na Europa de Leste, outros na Jugoslávia, outros na América do Sul, outros em África. Portanto, bastava mudar os nomes e podia ser África. Ou seja, infelizmente, há coisas que se estão a repetir numa série de espaços e em tempos diferentes, o que é um bocado assustador. 
Entrelivros: Estes são os livros pretos. O que seria então um livro branco?

GMT: Eu acho que se pensarmos no Senhor Valéry ou no Senhor Calvino, de certa maneira, são livros brancos, na medida em que podem dispor bem os leitores. É criar um mundo artificial, um outro mundo, um mundo paralelo, onde as pessoas se sintam bem e protegidas. Eu não tenho nada contra isso, bem pelo contrário. $O$ Bairro acho que é a criação de um outro mundo a que poderíamos chamar, seguindo a tua pergunta, um mundo branco, no sentido em que é um mundo onde nos sentimos protegidos. Eu acho que ali os quatro romances constroem um Reino em que, provavelmente, nós estamos desprotegidos e nos sentimos ameaçados. É importante transmitir às pessoas que realmente há momentos e sítios em que estamos ameaçados e desprotegidos e há outros sítios e outros momentos em que podemos estar protegidos e em segurança. Não sei o que serão os próximos romances, mas, para já, O Bairro pode ser um contraponto, mais claro, mais branco, em relação a esses romances.

Entrelivros: Falemos do acto que é escrever. Normalmente, quando um escritor começa a publicar, os seus textos da juventude são quase sempre intencionalmente esquecidos pelo próprio. Publicaste textos que já estavam escritos há muitos anos.

GMT: Sim, mas não são propriamente textos de juventude. Para já há uma questão que é esta: o facto de uma pessoa escrever um texto numa determinada altura e publicá-lo mais tarde, se o livro sair 5 ou 6 anos depois, como no meu caso, o livro que sai nada tem a ver com o livro original. Talvez seja difícil explicar isto mas se nós formos cortando, esmerando, o livro alterase por completo. Os livros de juventude eu não os publiquei. Aliás, escrevi dois romances mais de juventude, pelos vinte e tal anos, e nunca publiquei, nem vou publicar. Mas foram importantes para o meu processo. Acho que os livros que saíram são todos já depois dos 25 ou 26 anos, não sei. Eu comecei a escrever muito a partir dos 20, mas não me lembro de nenhum livro que tenha publicado e que tivesse sido escrito originalmente entre os 20 e os 20 e tal. A certa altura já comecei a baralhar as datas. Mas nunca considero livros de juventude. Os livros têm data de quando saíram: $2001,2002 \ldots$ são as datas deles. Porque realmente os livros são escritos nessa altura. Mesmo que tenham sido escritos há 3 anos, quando olho para eles altero coisas tão radicais que é um novo livro. Às vezes, acontece muito, até entre o momento em que eu o entrego ao editor e o momento em que sai, eu faço tantas alterações, tantos cortes, que é um novo livro por completo. Eu acho que as datas dos livros são as datas de saída.

Entrelivros: E esses textos que escreveste e não vais publicar, estão guardados? Não tens aquele impulso de destruir as coisas antigas?

GMT: Umas coisas já destruí, outras não sei onde tenho, outras guardo só por curiosidade. Há coisas que são interessantes até para a própria pessoa perceber o seu processo, como é que foi evoluindo, como é que foi mudando. É mais uma questão de documento, ter como documento, mas há muitas coisas que eu nem sei onde estão. Eu não sou muito, aliás não teria tempo, de 
olhar para o que fiz. Tento sempre ver o que quero fazer no momento. Quando pego em alguma coisa que já fiz há uns tempos, é com o olhar de hoje e é completamente diferente. É evidente que há uma série de coisas que para mim já terminaram e não vou voltar a elas, nem vou publicar, nem nada. Portanto, tudo o que está a sair agora, são coisas muito recentes.

Entrelivros: Li já há bastante tempo uma entrevista, creio, em que falavas desse tempo dos 20 anos, quando começaste a escrever a sério. Tinhas uma grande disciplina. las para o café cedo e lias, escrevias. Continuas a ter essa disciplina tão rigorosa?

GMT: Sim. Menos. Continuo a ter disciplina, mas não essa disciplina, por exemplo, ligada às manhãs. O Água, cão, cavalo, cabeça, por exemplo, foi escrito à noite. Ou seja, continuo a ter disciplina, mas não é uma disciplina que seja repetida. Às vezes num mês tenho uma determinada disciplina, escrevo a determinadas horas, e se calhar passados uns meses mudo. Realmente dos 20 aos 30 foi uma coisa de regularidade completa. Agora, por determinadas circunstâncias, não é possível ser tão - eu acho que não é disciplinado, eu continuo a ser disciplinado - mas não é possível manter esses horários todos com rigidez.

Entrelivros: E ainda escreves em cafés?

GMT: Menos. Ainda escrevo, mas bastante menos do que escrevia. Ou seja, gradualmente - e é interessante que é quase também a entrada nos romances que corresponde a isso, porque eu escrevo os romances em computador - fui deixando de escrever em cafés para passar a escrever no computador, em casa. É interessante porque isso também correspondeu a uma mudança. Vários escritores, no passado e ainda hoje, escrevem romances em cafés, à mão. Eu não consigo isso. A escrita à mão é uma escrita mais fragmentada. E portanto ultimamente tenho escrito mais a computador. Mas continuo a ir a cafés. O que faço nos cafés é mais a segunda fase da escrita, cortar, rever, etc. Isso faço muito em café. A primeira escrita, que é o mais importante, porque fica a pedra bruta, faço em casa. E depois é dar retoques, que são muito importantes. Eu demoro horas e horas. Demoro, sei lá, dez vezes mais a rever uma página do que a escrevê-la. E esta parte de revisão, corte, é em cafés. A escrita, agora, é mais em casa.

Entrelivros: É fácil estares concentrado num café?

GMT: Sim. Aliás, nesse período, até aos 30, era quase indispensável para mim ter um ruído de fundo para escrever. Neste momento, realmente, escrevo mais em casa, mas consigo concentrar-me perfeitamente em cafés ainda e gosto daquele barulho de fundo. Claro que se houver uma conversa localizada muito próximo de mim, isso pode perturbar-me. Mas o ruído de fundo de várias vozes, eu considero isso uma paisagem sonora que é muito estimulante. Até, às vezes, mais estimulante que o silêncio.

Entrelivros: És um escritor que pratica todos os géneros. Há algum que te dê mais prazer? 
GMT: Há muitas diferenças, claro, entre os vários livros, mas vejo que pertencem ao mesmo mundo. E portanto não sinto mais prazer a fazer uma coisa do que outra. Em certas alturas tenho mais prazer em escrever um determinado tipo de livros, ou num determinado tom. Passados seis meses ou um ano posso ter mais prazer a escrever num outro tom completamente diferente. O que eu tento é escrever num determinado momento, as coisas que me interessam, que me entusiasmam e que me dão prazer nesse momento. Não escrever apenas um género à força. Por exemplo, acabei há três meses de rever muito pormenorizadamente o Aprender a rezar na Era da Técnica, que é talvez o livro mais complexo e mais denso, e é um tipo de esforço tal que $\mathrm{eu}$, neste momento, não tenho vontade de escrever outro romance. Tenho vontade de escrever outras coisas, noutro tom. Mas eu não diria que tenho mais prazer em escrever uma coisa ou outra. Depende muito da altura.

Entrelivros: Tu ganhaste muitos prémios. O que é que achas que vem primeiro: primeiro o escritor é reconhecido e, a partir daí, chama a atenção desses prémios, ou primeiro ganha prémios e é reconhecido depois?

GMT: Felizmente, desde cedo os livros começaram a ter atenção de leitores especializados e isso foi desde o início. Acho que é uma coisa que está ligada. Até porque, normalmente, os elementos de um júri são pessoas escolhidas. Há júris melhores e há júris piores, mas, por exemplo, o do prémio Portugal Telecom do Brasil era um júri super seleccionado de alguns dos melhores críticos do Brasil. Portanto isso está muito ligado. O que eu acho claro é uma dissociação, eu acho que tento separar isso e acho que vou conseguir separar bem, entre aquilo que eu faço, que é da minha responsabilidade, e aquilo que é da responsabilidade dos outros. Aquilo que eu faço, e que é da minha responsabilidade, são os livros. As opiniões, os prémios que dão ou um prémio que possam não dar a um livro, isso é responsabilidade das pessoas, dos júris. Não é um trabalho meu. Quando eu escrevo um livro, o meu mérito é escrever o livro. Se o livro recebe um prémio, digamos que o mérito não é meu. $O$ trabalho não foi o meu. $O$ meu trabalho foi escrever o livro. A responsabilidade de atribuir um prémio não é nunca do autor. Portanto, eu distingo bem, porque a confusão entre as duas coisas é que pode provocar um auto-maravilhamento da pessoa, completamente disparatado. Aquilo em que alguém que escreve um livro - ou pinta, ou está ligado às artes plásticas, ou ao teatro - deve estar concentrado é no seu trabalho. E isso é que eu acho muito importante. Estar atento ao que vão dizendo sobre o seu trabalho, porque é importante ter a noção, mas perceber sempre que o seu trabalho deve ser mais ou menos independente do que vai acontecendo à sua volta. $E$ eu tenho tentado fazer isso.

Entrelivros: Para além da projecção que dão e do próprio prémio monetário há mais alguma utilidade num prémio?

GMT: Em termos monetários é realmente importante. Agora no Prémio Portugal Telecom no Brasil perguntaram-me o que é que eu iria fazer com o prémio monetário. Eu disse que uma das coisas que vou fazer é comprar tempo. Porque é realmente importante. Se eu tiver outros trabalhos e não tiver tempo e disponibilidade para escrever é evidente que isso pode ser um 
problema. O que me agrada nisto é poder comprar tempo. Um prémio dar-me a possibilidade de ter mais disponibilidade para continuar a escrever. Eu não quero mais nada, em termos materiais, se não a questão do tempo. O tempo agrada-me imenso e é a coisa mais valiosa que há. Não quero carros, nem casas, quero é tempo, tempo, tempo. E esses prémios podem dar a possibilidade de uma pessoa comprar tempo. É mesmo comprar tempo. Quando uma pessoa está a morrer, o que quer é tempo. Não quer mais uma casa, ou mais um automóvel. Não acredito que um moribundo, à última hora, o último pedido que faça seja mais um carro de alta cilindrada. Provavelmente o que ele vai dizer é: eu quero mais tempo, mais tempo de vida. Nós não precisamos de estar moribundos para percebermos que o essencial é o tempo. Nisso a filosofia clássica é muito importante. Portanto, eu tento que esses prémios e essas coisas que me vão acontecendo, me possibilitem ter mais tempo para ler, escrever, ir ver coisas. Isso é que é muito importante.

Entrelivros: Continuas a dar aulas. Queres continuar a manter actividades paralelas ou gostavas de te dedicares só à escrita?

GMT: Em todas as coisas há vantagens e desvantagens. A desvantagem pode ser não ter tanta disponibilidade para a escrita. Mas há a vantagem de poder contactar com pessoas, a geração de vinte e tal anos, em diferentes situações. É ter um conjunto de experiências e de contactos que são importantes. Eu acho que podia ser perigoso se eu estivesse constantemente fechado num quarto, sem contactar com pessoas. Aliás, eu tenho quase uma certa tendência para me fechar e dar aulas obriga a pessoa a sair um pouco de si própria e virar-se para o exterior, o que eu acho que é importante. Tal como, por exemplo, algo que eu há algum tempo via com desagrado e que agora já me começa a dar um certo prazer, que são as viagens. Eu durante muito tempo gostei muito de viajar, depois recentemente deixei de gostar tanto e agora estou a ganhar um novo gosto em viajar. São, precisamente, um conjunto de experiências que nós podemos pensar, à primeira vista, que são uma perda de tempo para a escrita, mas, se as virmos de um outro prisma, são a possibilidade de contacto com outros pormenores de vida. Talvez daqui a uns anos só escreva e não tenha outro tipo de trabalho, mas para já acho que é importante ter estas duas actividades, até para dosear um pouco o meu fechamento em relação ao mundo. Viajar é engraçado. Lembro-me que há dois ou três anos disse que não gostava nada de viajar e hoje, em 2008, estou a ter um impulso e uma nova vontade de viajar e estar duas semanas em Buenos Aires como provavelmente vou estar. É um conjunto de experiências que me começa a entusiasmar. É engraçado como os nossos gostos vão mudando muito e às vezes em poucos anos.

Entrelivros: E as viagens de trabalho? São diferentes?

GMT: Sim, mas eu acho que para quem escreve, assim como para um artista plástico por exemplo, é muito difícil separar trabalho de não trabalho, num certo sentido. É evidente que há momentos em que estou a escrever e há momentos em que não estou a escrever. Mas os momentos em que não estou a escrever, se estou num café, por exemplo, e há uma discussão entre um casal numa mesa ao lado, eu quase instintivamente absorvo alguma coisa desses 
pormenores. Portanto, a observação é também, de certa maneira, um trabalho. Claro que não é um trabalho directo de escrita, mas a observação de coisas diferentes, de pessoas, de reacções, é algo que vai alimentando um escritor. Eu considero um trabalho de escrita uma coisa que eu faço com alguma regularidade, que é andar muito, uma hora ou meia hora, pela cidade, a ver as pessoas. Eu considero isso um trabalho de escrita, apesar de não pegar na caneta nem no papel. Mas é um trabalho de observação, em que vou pensando, vou observando, e considero que isso é a primeira fase da escrita.

Entrelivros: Dizias há pouco que já tinhas publicado quase tudo o que tinhas escrito anteriormente. Agora que começas a publicar coisas mais recentes, não vais publicar tantos livros como publicaste nestes últimos anos?

GMT: Não sei. Provavelmente não. Mas não há nenhuma regra. Eu acho importante não ter nenhuma regra quanto a isso. Ou seja, eu acho que muitas vezes há uma adaptação da saída dos livros a um ritmo que não é literário mas que é comercial. Por exemplo, sair um romance de dois em dois anos. A máquina de Joseph Walser e o Jerusalém saíram com três meses de diferença, que é uma coisa comercialmente absurda. Mas, por exemplo, no ano passado saíram só dois livros: Breves notas sobre o medo e Aprender a rezar na Era da Técnica. Não sei se este ano será um ritmo maior, menor, não sei. Acho que em 2004 saíram seis ou sete livros e isso será difícil voltar a acontecer. Mas não acho isso nada de estranho. O que eu quero é não ter regras a esse nível. Não quero entrar nesse tipo de padrão de um autor ter que publicar só dois livros ou só um livro. São padrões não literários. Se eu na altura conseguir escrever muito e rever muitos livros, podem sair muitos livros. Se eu não conseguir rever com atenção um livro, pode não sair nenhum. O que eu acho interessante é que a data de saída não é o mais relevante. Podiam sair 50 livros no mesmo dia. A data relevante é a data em que um leitor lê esse livro. Uma das coisas mais interessantes que me acontece, e aconteceu-me isso há dois, é chegar alguém e dizer: eu li ontem O Senhor Valéry. É um livro que saiu em 2002, há 6 anos. $E$ eu fico muito contente, porque é isso: 0 momento em que o livro sai não é importante, o momento em que o livro é lido por um determinado leitor é que é importante. Há pessoas que leram O Senhor Valéry em 2002, pessoas que leram em 2003, pessoas que leram em 2008, pessoas que, espero eu, o vão ler em 2012. Portanto, se nós pensarmos que o importante é o momento em que o leitor lê, que pode ser completamente diferente para cem leitores, a data de saída do livro tem pouquíssima importância. E é assim que eu tento pensar, que o momento importante é o momento em que cada leitor lê um livro.

Entrelivros: Mas a publicação de tantos livros não dificulta o acompanhamento da tua obra por parte dos leitores?

GMT: Pois, eu compreendo que é muito difícil. Às vezes aparecem pessoas na Feira do Livro com os livros todos, mas mesmo todos. Há assim uns loucos que acompanham tudo. Mas percebo que é difícil. Só que quem faz não pode estar a alterar o ritmo do que faz pelos critérios da recepção. É um pouco isso que eu tento seguir. É evidente que se uma pessoa conseguir ler os livros todos fica com uma ideia melhor do que eu faço. Ninguém tem uma ideia do que eu faço 
se ler um livro ou dois meus. Há muito mais livros, os livros são muito diferentes. Para alguém ter uma ideia do que eu faço tem que ler vários livros. Agora, não é preciso que leiam todos. Mas felizmente, como disse, há várias pessoas que vão acompanhando e a maior parte dos livros são livros pequeninos que se lêem com facilidade, portanto acho que é possível ir acompanhando. Às vezes há esse prazer, ir acompanhando todos os livros de um autor e no meu caso pode ser mais difícil. Não sei. Vamos ver como vai ser o ritmo do futuro. Mas eu acho que é importante quem está a fazer não alterar os seus modos de fazer por, por exemplo, uma característica que é claramente destruidora. Nas livrarias, um livro que sai está dois meses numa livraria e depois desaparece. Eu, como alguém que escreve, não posso alterar os meus modos de fazer por causa dessa regra, que é uma regra não literária, puramente comercial. A mim agrada-me que um livro possa ser lido três ou quatro anos depois de ser publicado. Perdeu-se um bocado isso pelo facto de as livrarias estarem constantemente a mudarem os livros, mas um livro não é para ser publicado em Novembro de 2007 e ser lido, por todos os leitores, em Novembro de 2007. Isso não é a essência de um livro. A essência do livro é uns lerem-no em Novembro de 2007, outros em Novembro de 2008, outros em 2015, outros em 2025, se tudo correr bem. Isso é o normal. Eu gostava que os leitores fossem lendo quando for, não precisam de ler um livro mal ele sai.

Entrelivros: Foi por teres publicado muitos livros em pouco tempo que publicaste em várias editoras?

GMT: Sim, um pouco. E também dirigia livros com um certo tom para editoras que tinham a ver com esse tom. Por exemplo, a série Enciclopédia, que está a sair na Relógio d'Água, sai lá porque faz sentido. A editora tem a ver com aqueles livros. Tal como os livros que estão a sair na Caminho, acho que têm a ver com aquela editora. Acho que foi um pouco isso, dirigir os diferentes tons para diferentes editoras. 


\section{Entrevista concedida ao Círculo de Leitores Online}

Quase não se nota, quase nos podemos enganar. Mas há um fio, um transparente e inquebrável fiozinho que liga todas as palavras dos seus livros. Falará de loucos, de jogos, de inversões, de mundos ao contrário, de contrariadas solidões, de insólitos rostos, de estranhos lugares com pessoas tão estranhas como cada um de nós. O mago é Gonçalo M. Tavares. Talvez não goste do nome. A sua arte talha-se afinal numa constante leitura dos outros, só depois numa descoberta da sua própria escrita.

Nasceu em Angola, tem 34 anos de idade e começou por editar um livro de poesia seguindo-se o ensaio, a ficção, o teatro. Com $O$ Senhor Valéry obteve o Prémio Branquinho da Fonseca da Fundação Calouste Gulbenkian e do jornal Expresso, e o Prémio Revelação de Poesia da APE com Investigações (Novalis).

Em 2004 é distinguido com o Prémio LER/Millennium BCP, em 2005 com o Prémio Literário José Saramago. Jerusalém inclui-se no que designa de Livros Pretos, a tocarem o desencanto.

Círculo de Leitores online: Prefere um leitor (dos seus livros) satisfeito ou perplexo?

Gonçalo M. Tavares: Talvez o prefira, no final, satisfeito por estar perplexo. Alguém ficar intrigado é, julgo eu, um ganho. Há uma satisfação diferente quando se entende tudo por completo ou quando se entende em parte, e a parte que falta provoca mudanças, curiosidade, etc. Eu, pessoalmente, como leitor não gosto de ler aquilo que já sei ou estou à espera.

CLonline: A pergunta anterior não é obviamente inocente. Sente-se em jogo com o leitor ou consigo mesmo? Há uma notória inversão de lógicas neste livro, e nos editados anteriormente. Essa construção é algo com que se diverte e a que acedemos de fora, ou em que nos quer incluir?

GMT: Considero que estes três romances, Um Homem: Klaus Klump, A máquina de Joseph Walser, e agora o Jerusalém são livros emocionais e portanto que incluem o leitor no seu mundo. Não há nada de abstracto em Jerusalém, a violência entre pessoas e os laços amorosos e familiares existem em todo o lado. Estamos todos no mesmo barco: temos medo e se necessário somos agressivos.

CLonline: Permita-me a insistência no termo "jogo". O lugar que conta, as personagens que cria têm vida própria ou são peças que move a seu belprazer? E, a movê-las, pretende afirmar o quê com este livro? 
GMT: Quando escrevo um livro nunca sei o que vou fazer, o que vai sair. Começo a escrever sem saber nada: sem saber se há personagens, quantas são, sem saber o que vai acontecer, desconhecendo factos, episódios. Escrevo, apenas. Nunca escrevo com um plano. Pode parecer estranho para quem lê, mas é mesmo assim: a cada linha do Jerusalém não sabia o que iria acontecer a seguir. Portanto, as personagens não as movo ao meu bel-prazer. É como se nem sequer visse as personagens, elas aparecem sem eu as convidar.

CLonline: Que lugar habitam as personagens? Um lugar paralelo ao nosso? Subterrâneo? Estrangeiro?

GMT: Aparecem num lugar paralelo ao nosso. Não é num lugar estrangeiro, porque não há nenhum lugar estrangeiro ao medo, à agressividade, à loucura, à ligação entre pais e filhos. Pertencemos todos ao mesmo país.

CLonline: Theodor afirma a procura de Deus como um imperativo de sanidade: "[...] um homem que não procure Deus é louco. E um louco deve ser tratado". Por que o ancorar da razão em Deus?

GMT: A ideia mais antiga, que o ser racional por excelência, que é o Homem, vai espalhando pelo mundo é a ideia de Deus. A ideia de Deus é uma consequência de um pensamento racional absoluto. Podem existir, mas não se conhecem deuses dos cães ou dos mosquitos. A razão e Deus estão muito ligados. Theodor, o médico, também sente isso.

CLonline: Theodor é um cientista ou um crente?

GMT: Julgo que é as duas coisas. Theodor é médico e os médicos contactam com um dos limites essenciais do humano: o limite da saúde. Este contacto com os limites do corpo humano é sempre muito forte, não será por acaso que muitos dos que têm profissões que trabalham com os limites humanos se aproximam de crenças mais ou menos explícitas.

CLonline: Há uma sensação de ameaça ao longo do livro. Como se tudo pudesse acontecer - e como se tudo o que acontece não tivesse necessariamente um sentido. Concorda, ou é aparente o acaso?

GMT: Todos os acontecimentos do livro são, ao mesmo tempo, um acaso, e como que um destino. O livro talvez não pudesse terminar de outra forma.

CLonline: A cura, dirá Gomperz, passaria pelo esquecer de um trajecto. A loucura abre ou fecha portas?

GMT: A interpretação romântica da loucura, associando-a aos actos amorosos ou criativos, não me é muito agradável. Estar apaixonado ou ser criativo nada tem a ver com a loucura pesada, dura, que é algo que se deve respeitar pois relaciona-se acima de tudo com o sofrimento humano e individual. A loucura é uma coisa má e negra. Os textos de Artaud, por exemplo, são excelentes. A loucura de Artaud foi certamente terrível e negra. 
CLonline: Quem não é louco neste livro?

GMT: A prostituta, o médico, quase todas as personagens são como nós. A mesma extraordinária porcaria saudável.

CLonline: Fez algum tipo de pesquisa para este livro?

GMT: O instinto de pesquisa é este: quero tentar perceber. Começamos a pesquisar quando não sabemos e nunca se pára de pesquisar, porque nunca se sabe, sobre um determinado assunto, tudo. Para mim a escrita é um estado de investigação, e o que me interessa essencialmente é investigar os comportamentos humanos.

CLonline: Permita-me voltar um pouco atrás. Como surgiu a escrita de Jerusalém? Enviou o original a concurso mas inclui este inédito no subtítulo Livros Pretos. Por que esta designação?

GMT: O romance Jerusalém pertence aos livros pretos, e tem uma ligação clara com os romances Um homem: Klaus Klump e A máquina de Joseph Walser, ambos editados na Caminho. São livros pretos, no sentido de uma certa dureza, e de um certo desencanto. Desencanto é a interrupção do canto, é uma coisa que incomoda.

CLonline: Para além da ordem interna de cada um dos livros, designa-os "Cadernos", mais especificamente, "Cadernos de Gonçalo M. Tavares". O que liga estes cadernos?

GMT: É evidente que os Cadernos têm ligação entre si. São escritos pela mesma pessoa. Claro que, por vezes, há uma ideia de que uma pessoa é só uma pessoa. Mas não, todos somos uma quantidade de coisas diferentes, como toda a gente sabe e sente. Por vezes no mesmo dia, em menos de dez ou doze horas sinto-me completamente angustiado e farto de uma certa existência estúpida que toda a gente tem, e passado algumas horas posso estar genuinamente divertido com algo dentro da minha cabeça. O mundo tem vários tons e devemos respeitar isso. Em relação aos cadernos, e tentando organizar mentalmente os diferentes livros, vejo que há livros que têm objectivos diferentes. Com certos livros tento interferir na linguagem, com outros tento interferir na literatura e com outros ainda (onde julgo se inclui o Jerusalém) tento interferir na existência das pessoas ou pelo menos na forma de se pensar sobre certos acontecimentos. Há livros que os vejo como investigações, livros que muitas vezes são fundamentais para outro tipo de livros mais concretos como os romances. No entanto, apesar de colocar no meu trajecto principal alguns livros, como os romances, livros de estrutura mais clássica, não quero deixar nunca de escrever livros que procuram caminhos diferentes na literatura, fora de qualquer género literário assente. A classificação de géneros literários é uma prisão e uma predeterminação do exterior que quem escreve não deve aceitar. Se do escritor saiu um romance, tudo bem. Se saírem naturalmente contos, tudo bem. Mas se sair qualquer outra coisa, que não é colocável em nenhum género literário, tudo bem à 
mesma, e muito bem mesmo, desde que seja algo que ajude a investigação sobre a linguagem e sobre as ideias.

CLonline: Gostaria de saber um pouco mais sobre o seu método de escrita.

GMT: Não há nenhuma elaboração mental prévia. As personagens e os acontecimentos vão surgindo à medida que escrevo. Por vezes, a meio, há pressentimentos sobre 0 que poderá vir a acontecer, mas nunca sei exactamente o que vai suceder. A folha está em branco, começo a escrever. No livro Biblioteca, publicado recentemente relembrei uma brincadeira de Lewis Carroll que de certa maneira se ajusta à descrição do meu método de escrita: começo a escrever no início, continuo a escrever, e quando chega ao fim, paro. É este o meu método.

CLonline: Este tipo de pergunta - que tenta desmontar a sua escrita - alicia-o a mentir?

GMT: Não. Mas eu próprio não consigo desmontar a minha escrita, precisamente pelo que disse antes: quando escrevo pela primeira vez algo não sei como o faço. Não domino esta primeira parte. Começo a escrever, simplesmente. A segunda parte, sim, a de revisão, a de vigilância sobre o que foi escrito, aí domino, sei como faço. Mas o essencial já está antes feito, e isso não sei desmontar. Apenas rezo para continuar a fazer, mesmo que nunca venha a saber como faço.

CLonline: Como e quando começou a escrever?

GMT: Escrevi muito à mão, em cadernos, durante muitos anos. Comecei cedo a ler e a escrever, não consigo separar a leitura da escrita. A certa altura percebi que escrevia quase instintivamente e que precisava disso para me sentir bem. Quando não escrevia ou não escrevo, fico irritadíssimo. Depois estive muitos anos a ler e a escrever obsessivamente. E no meu cantinho. Só comecei a publicar aos 31 anos. Como às vezes brinco: foi para desocupar metros quadrados da minha casa.

CLonline: É isso que se considera: um escritor?

GMT: Escrever é um acto natural, quase instintivo. Escrevo mais naturalmente do que falo. Não tenho necessidade de falar, tenho necessidade de escrever. Necessidade e instinto são palavras que não têm a ver com ofícios, relacionam-se sim com o organismo. Escrever não é um ofício, apesar de requerer uma certa disciplina.

CLonline: Novos projectos?

GMT: Há muita coisa já feita ainda para sair. E estou a fazer outras coisas. Sairão provavelmente alguns livros ainda este ano. Estão também a começar a acontecer várias traduções de livros meus para França, Espanha, Brasil, Índia, talvez Itália. O que é óptimo. 
CLonline: Uma última pergunta. É Mylia quem se refere a Jerusalém. "Se eu me esquecer de ti, Jerusalém, que seque a minha mão direita”. Que Jerusalém é esta?

GMT: Eu só escrevi o livro. Não sei mais nada. 


\section{Entrevista concedida a Sérgio Rodrigues, do blogue Todoprosa, especial para Veja Meus Livros}

Os dois livros que o escritor português Gonçalo M. Tavares está lançando na Bienal do Rio, ambos pela editora Casa da Palavra, saíram em Portugal com um intervalo de sete anos: O Senhor Valéry é de 2002 e 0 Senhor Swedenborg, de 2009. Mas a cronologia não faz muita diferença para o autor de uma obra prolífica que desde sua estreia, em 2001, já alcançou o impressionante número de 27 títulos. É que seu singular "método", como diz Tavares, envolve acumular o máximo de "matéria bruta" em disciplinadas sessões diárias à frente do computador para, anos depois, recuperado o distanciamento diante das palavras, dar forma final aos volumes.

Estes se agrupam sobretudo em duas séries. O Bairro, ainda em andamento, reúne pequenos perfis fantasiosos de escritores como o poeta francês Paul Valéry e o espiritualista sueco Emanuel Swedenborg. O Reino, tetralogia já fechada, é composto de romances robustos e sombrios como Jerusalém e Aprender a Rezar na Era da Técnica, publicados no Brasil pela Companhia das Letras. Neles é possível identificar o fio condutor de uma investigação sobre a fronteira difusa entre o racionalismo e a maldade. "A literatura tem que perturbar alguma coisa", diz Tavares.

O "método" tem funcionado. Um dos mais festejados escritores de sua geração em todo o mundo, Gonçalo M. Tavares, 41 anos, já teve livros lançados em 32 países e ganhou prêmios importantes como o José Saramago, em 2005, e o Portugal Telecom, em 2007. Ao Ihe entregar o prêmio que leva seu nome, o Nobel português proferiu uma frase que ficou famosa: "Gonçalo M. Tavares não tem o direito de escrever tão bem apenas aos 35 anos: dá vontade de lhe bater."

$\mathrm{Na}$ entrevista abaixo, concedida ao site de VEJA numa livraria de Ipanema, Tavares fala de sua disciplinada rotina de trabalho, defende 0 hibridismo de gêneros, faz acenos simpáticos à literatura brasileira contemporânea e prevê um futuro glorioso para a língua portuguesa no cenário mundial. 
Veja: É compreensível aquela frase de Saramago sobre ter "vontade de the bater", mas talvez se devesse incluir entre os motivos sua produtividade absurda. Como se mantém um ritmo desses sem perda de qualidade? Quando você estreou, em 2001, tinha muita coisa pronta?

Gonçalo M. Tavares: Sim, muita. Eu tenho muitos livros já escritos, escrevi imenso entre os 20 e os 30 anos. Era uma fase obsessiva, às seis da manhã já estava a escrever. Escrevia em cafés, em cadernos, depois é que passei para o computador. Eu tinha muito claro que queria separar a escrita da edição (publicação). Acho que foi a melhor opção que eu fiz, instintiva, mas das mais sensatas: pensar que a edição iria perturbar alguma coisa. Eu tinha a essa altura muito claro que não devia editar antes dos 30, e escrevia imenso. Mas a quantidade não é exatamente essa, porque os livros estão a formar blocos. $O$ Reino são quatro livros, mas é um. O Bairro são dez livros pequenos, mas é um. Gosto da ideia do livro como uma espécie de tijolo, que tem uma vida própria, mas ao mesmo tempo, junto com outros tijolos, permite construir algo.

Veja: Aquele ritmo e aquela disciplina ainda se mantêm?

GMT: Minha rotina mudou ligeiramente, mas a disciplina mantém-se, mais ou menos. Quando há viagens, é diferente, mas em Lisboa minhas manhãs são fechadas. Escrevo das oito e meia até as duas. Nessas horas me desligo de tudo, não atendo telefone, não leio e-mails. Escrevo num ateliê que fica a cinco minutos de casa, e no caminho, a pé, procuro nem olhar para as bancas de jornal. Não tenho um número de linhas a cumprir. Há dias em que escrevo imenso, há dias em que escrevo menos. Não quero romantizar em excesso, mas em momentos como nesta viagem, estando há alguns dias sem escrever, fico irritado. Nos dias em que estou a escrever, saio para a rua às duas ou três da tarde com a sensação de que está tudo ganho, com alegria. Tento defender esse espaço do mundo exterior e principalmente das pessoas que mais gostam de mim. Hoje é um pouco diferente porque faço muitas viagens, mas naqueles primeiros dez anos não perdi mais de oito ou nove manhãs.

Veja: Você está no Brasil para lançar mais dois volumes de $O$ Bairro, que são contos ou novelas curtas de caráter lúdico, cada um inspirado por um escritor. No caso desses dois, sobretudo O Senhor Swedenborg, o lado de jogo fica ainda mais acentuado pelo uso intensivo de figuras geométricas. De repente, a palavra ficou insuficiente?

GMT: Me agrada muito essa ideia do desenho ser uma outra forma de escrever. Uma coisa que me choca um pouco foi o desenho ter entrado numa espécie de subterrâneo, como algo que não existe no pensamento, como se este só pudesse ser expresso pela linguagem. $O$ desenho afastou-se do raciocínio. N'O Bairro há muito isso, e especialmente em 0 Senhor Swedenborg. Quando estou a escrever a mão, há coisas que penso através do desenho e só consigo expressar através do desenho. Os desenhos nesse livro são claramente para serem lidos e não para serem vistos. 
Veja: Aliás, você pretende cumprir a promessa de povoar $O$ Bairro de todos aqueles "senhores" que aparecem no traçado inicial do projeto?

GMT: Não, vou morrer antes, é evidente (risos). Mas gosto de projetos em que não se sabe bem o que vai acontecer.

Veja: $O$ Bairro é pura fantasia e jogos de linguagem. Nos quatro romances da série $O$ Reino, em que a atmosfera é mais pesada, personagens têm nomes de sonoridade centro-europeia e vivem em países não identificados, num momento histórico nebuloso. A definição de ficção realista é discutível, mas seria o caso de dizer que você rejeita o realismo ou pelo menos aquele tipo de realismo que Paul Valéry ironizou na frase: "A marquesa saiu às cinco horas"?

GMT: O Reino é realista no sentido de descrever uma realidade que poderia ter existido, mas no nível da linguagem, sim, afasto-me por completo do realismo. Acho que um livro que fique muito preso à repetição do cotidiano, da vida normal, pertence à vida normal. A literatura tem que perturbar alguma coisa, nos fazer sentir que entramos num outro mundo. Tem que fazer parar. Gosto da ideia de que a pessoa leia e possa interromper, reler. Acredito que um livro entre no campo de força do literário quando a pessoa, depois de o ler, sente que vai voltar a ele. Mesmo que não o releia, vai pensar sobre ele.

Veja: Um traço marcante da sua ficção é a linguagem híbrida, entre a narrativa e o ensaio. Alguns críticos têm dito que a narrativa, o romance, está perto do esgotamento. Você reconhece essa crise? O hibridismo de gêneros pode ser interpretado como uma resposta a isso?

GMT: Se nós virmos a narrativa como contar uma história, pode-se dizer que desde os gregos estamos repetindo certas estruturas, trabalhando com os mesmos sentimentos humanos, com pequenas variações. Também no ensaio há quem diga que depois de Platão tudo são notas de rodapé. Eu pessoalmente tenho dificuldade de distinguir uma forma pura, o puro ensaio ou a pura ficção. Para mim, aquilo é o mesmo mundo, como leitor eu posso passar de dez páginas de ficção para dez páginas de ensaio. Eu nunca penso: "Agora vou escrever um romance". Eu gosto muito da palavra "texto", que não tem essa marca do gênero literário, que eu acho que é uma marca limitadora do potencial enorme do alfabeto. Instintivamente, escrevo, e instintivamente aparece uma história, mas o pensamento entra na história. $O$ raciocínio também é uma narrativa. Penso que a linguagem, qualquer linguagem, na narrativa ou no ensaio, é o que mais se aproxima de compreender alguma coisa do ser humano. É isso que me interessa.

Veja: Às vezes, suas narrativas dão a impressão de terem o pensamento como motor, com as peripécias e os fatos sempre subordinados às ideias.

GMT: Não sei. Também não consigo ver o pensamento antes da narrativa. Eu não planejo meus livros. Quando começo a escrever um texto, não sei que personagens vão aparecer, que acontecimentos vão aparecer. Começo a escrever quase instintivamente. Nunca parto de ideias prontas, nunca penso: "Vou escrever sobre tais ideias". Vou escrevendo. Mas acho que os livros 
devem provocar reflexão e tento não abdicar disso. O prazer é fundamental, mas eu tento que seja um prazer que obriga a parar, a pensar. Entendo a literatura como um lugar de paragem. Eu gosto mesmo é de histórias, de contar histórias, mas espero que sejam histórias diferentes das que se podem contar em outros meios, como a televisão.

Veja: Existem autores contemporâneos que, quando lançam um livro novo, fazem você correr para comprar?

GMT: Acompanho dezenas de autores. Não é dizer que vá correndo, mas procuro ler. Gosto de coisas muito diferentes, como o Bairro mostra um pouco. Não é que ali estejam os meus autores preferidos, aquela seleção tem mais a ver com o instinto de saber quais são os mais lúdicos, mas leio desde ensaio até ciência, ficção e poesia. Gosto muito do mundo imaginário e gosto muito do mundo realista. Por exemplo, Cormac McCarthy é um autor que me agrada, mas também gosto de Ítalo Calvino. Mas minha grande referência em literatura é clássica: Sêneca, Cartas a Lucílio, que me marcou muito. E na filosofia o alemão Peter Sloterdijk, de quem leio tudo que é traduzido.

Veja: Seu próximo livro já está pronto? Pode falar um pouco dele?

GMT: Eu tenho um método que é escrever a matéria bruta e depois deixar de lado um tempo. Escrevo e esqueço, fico no mínimo um ano ou dois sem olhar para aquilo. Depois volto, retomo, corrijo, corto. Principalmente, corto. Tenho necessidade desse afastamento para ter um olhar realmente crítico, quase como um leitor. Os livros que saem são livros que tiveram esse percurso. Portanto, o que eu vou publicar em dezembro não é o que escrevi em maio deste ano. Chama-se Canções Mexicanas e teve origem numa viagem que fiz à Cidade do México. É uma coisa que eu não sei bem o que é. São textos.

Veja: A literatura brasileira, vista de Portugal, está num momento ruim? Anda na moda entre certos críticos daqui elogiar a exuberância da literatura portuguesa e até o domínio maior que vocês têm da língua, o modo como exploram todos $\mathrm{s}$ recursos sintáticos $\mathrm{e}$ vocabulares do idioma...

GMT: Não tenho essa ideia. Os elementos que tenho do lado de lá me dizem que não há uma diminuição objetiva da edição de autores brasileiros, pelo contrário. Talvez os últimos anos tenham sido aqueles em que mais autores brasileiros, sem ser os clássicos, têm sido editados. Dezenas estão a ser editados e são recebidos com a sensação de que aquilo dá uma força, uma variedade que acrescenta muito à literatura de língua portuguesa. Autores portugueses não escrevem daquela maneira. Não tem a ver com ser melhor ou pior, mas completamente diferente. Sobre a questão da língua, é engraçado: 0 discurso em Portugal é mais ou menos esse, mas ao contrário. A ideia que há lá é que a língua utilizada pela literatura portuguesa é mais formal e que a língua utilizada pela literatura brasileira e africana é mais criativa. É essa coisa do outro ter sempre algo que nós não temos. Se a língua portuguesa só existisse em Portugal ou só existisse no Brasil, ficávamos muito a perder. Se há uma coisa que não me entusiasma no português brasileiro são aquelas palavras do inglês, que no Brasil se usa bastante mais. Mas em Portugal temos 
uma espécie de alfândega, como se cada palavra que quisesse entrar tivesse que mostrar documentos, provar que não tem crimes no passado e que tem trabalho garantido para os próximos seis anos, e isso é também excessivo. Mas vejo as coisas cada vez mais juntas. A circulação de informações nunca foi tão grande, o contágio começa a aparecer muito mais e começa a formarse, felizmente de forma quase instintiva e natural e não através de um decreto, uma massa única da língua portuguesa, que é uma potência enorme em movimento. Seria preciso falharmos muito para que o português não fosse daqui a dez anos uma das principais línguas do mundo, até em circuitos mais institucionais. 


\section{ANEXO 3}

\section{GONÇALO M. TAVARES NA VISÃO DE CRÍTICOS E AUTORES}

"Mas no panorama actual da literatura portuguesa não há ninguém tão aplicado na construção daquilo a que, com muitas suspeitas, chamamos "obra" mobilizando a ideia de autor, de projecto e de sistema - como Gonçalo M. Tavares. [...] Numa altura em que uma nova inocência épico-narrativa restaurou a narração do tipo "A marquesa saiu às cinco horas", é bom encontrar quem se coloca à distância da tagarelice e do Kitsch novelescos" (António Guerreiro, "Expresso", maio de 2004, sobre A máquina de Joseph Walser).

"À sua maneira, este livro é também um mausoléu, como aquele de Enzensberger (...). Mas é, sobretudo, a construção de um labirinto onde o escritor se deixa descobrir como leitor e nos faz perceber que a leitura é o a priori da sua escrita" (António Guerreiro, "Expresso", Maio de 2004, sobre Biblioteca).

"Creio que a boa literatura portuguesa passa, sem dúvida, por este autor" (Ondjaki, junho de 2004).

"Sem dúvida que de toda a nova geração de escritores ele (Gonçalo M. Tavares) é o nome de amanhã" (Pedro Teixeira Neves in Magazine Artes, maio de 2004, sobre A máquina de Joseph Walser).

"[...] magnífico primeiro romance. [...] Um dia, quando se fizer a história literária deste começo do século em Portugal, a obra de Gonçalo M. Tavares ocupará um lugar proeminente. [...] Gonçalo M. Tavares escreveu um livro extraordinário, uma obra-prima. [...] Eu sei que para usar a expressão génio se exige cautela e parcimónia. Ainda assim, arrisco. Para mim, este romance não é apenas o melhor que li em português nos últimos anos. É um livro - e não temo a palavra - genial. [...] A inteligência do autor, menos irónica do que noutros livros, aparece-nos em toda a sua extensão. Ou seja, o texto já não 
reflecte o brilho do autor. É ele próprio 'inteligente"' (José Mário Silva, Diário de Notícias, 20 de novembro de 2003).

O senhor Valéry, um livro inteligente e premiado [...]" (Expresso).

"[...] impagável senhor Valéry” (José António Gomes, Expresso).

"[...] a mais importante revelação literária em 2002 é, sem dúvida, Gonçalo M. Tavares" (Eduardo Prado Coelho, Mil Folhas, Público).

"Nasce um escritor" (Miguel Real, Jornal de Letras).

"[...] perturbadora é toda a escrita de Gonçalo M. Tavares" (Miguel Real, Jornal de Letras).

"É sempre interessante assistir, no momento exacto em que acontece, ao aparecimento de um novo escritor" (Pedro Mexia, Dna).

"Estamos perante um caso muito sério da literatura portuguesa "(Pedro Mexia, Dna).

"Mas podemos ir mais longe, e invocar o infeliz Buster Keaton, estóico perante a desgraça, ou a esperteza um pouco bizarra do Senhor Hulot de Jacques Tati. Muito boa companhia, portanto. [...] uma pequena pérola" (Pedro Mexia, Dna, sobre $\mathbf{O}$ senhor Valéry).

"[...] perfeitinho também de alma sua gentil [...]" (Jorge Listopad, Jornal de Letras).

"[...] com páginas de prodígio [...]" (Armando Nascimento Rosa, Público, acerca de Livro da dança).

"O senhor Valéry tem tanto de estranho como de brilhante" (Sara Belo Luís, Visão). 
"O autor [...] é capaz de trazer realmente algo de novo às letras portuguesas" (Sara Belo Luís, Visão).

"Escreve com um poder inimitável" (Paulo Cunha e Silva, Diário de Notícias).

"[...] a pergunta consiste em querermos saber se Herberto Helder está presente pela continuidade que permitiria estabelecer com a poesia de Gonçalo M. Tavares [...] se pelo modelo de ruptura que instituiu na história da poesia portuguesa contemporânea e que Gonçalo M. Tavares estaria de certo modo a repetir" (Eduardo Prado Coelho, Mil Folhas, Público).

"[...] estamos a entrar a pés juntos num continente novo e desconhecido, mas que já existe inteiramente configurado e coerente" (Eduardo Prado Coelho, Mil Folhas, Público).

"[...] um dos maiores poetas para o século XXI" (Pedro Sena-Lino, a Phala).

"[...] poesia conceptual, afirmativa, empenhada na investigação da linguagem" (Ana Marques Gastão, Diário de Notícias).

“[...] ousado e saudável (in "A capital", sobre O senhor Valéry).

“[...] palavras novas, rápidas, soltas” (Sandra Oliveira, DN Magazine).

"[...] porque se trata, vale a pena sublinhar, de um escritor de ideias. O que é raro em qualquer geração. [...] Gonçalo Tavares representa um novo paradigma na literatura portuguesa: um autor cerebral, preocupado com o método e com a lógica literária do jogo, um escritor com preparação filosófica, notória em aforismos e frases por vezes brilhantes. [...] Mas sabemos que os "Cadernos de Gonçalo M. Tavares" estão ainda no início, e que podemos estar perante uma verdadeira arca pessoana" (Pedro Mexia, Diário de Notícias, março de 2003). 
"[...] um dos mais prolíficos e elogiados escritores (poeta, dramaturgo, ficcionista) da novíssima geração da literatura portuguesa" (Dna, Revista do DN, fevereiro de 2003).

"Livros [...] que Ihe valeram, por parte da crítica, a classificação de maior revelação literária portuguesa dos últimos anos" (Revista LER, Verão 2003, Sara Belo Luís).

"A aparição de Gonçalo M. Tavares no panorama literário português, há pouco mais de um ano, foi no mínimo invulgar, para não dizer atípica. Em vez de apresentar o tradicional primeiro livro, este autor surgiu de repente com uma estruturadíssima série de obras (escritas ao longo de dez anos) e que foi publicando, com um intervalo de poucos meses, em editoras de cariz diverso" (José Mário Silva, DN, 10 de julho de 2003).

"Dir-se-ia que se trata de um livro para crianças. De certo modo, é. Para as crianças que um dia inevitavelmente seremos. [...] este senhor Valéry tem uma longa genealogia [...] julgo que pode vir de Diderot [...]. Mas pelo caminho troca dois dedos de conversa com o nosso Bernardo Soares do Livro do desassossego e ambos se referem ao Wittgenstein que acabaram de ler. É claro que no topo desta constelação se encontra sempre o inevitável Lewis Carroll, mas também podemos convocar o francês Jacques Roubaud. [...] nesta espécie de pé atrás em relação à vida e à sua roda de decisões prementes 0 senhor Valéry não destoa muito desse estranho e fascinante Bartleby de Melville" (Eduardo Prado Coelho, Mil Folhas, Público).

"O senhor Valéry é um conjunto de vinte e cinco micro-histórias protagonizadas por um senhor franzino e de pequena estatura que não gosta de ser posto em causa e é, no fundo um solitário [...]. Este Senhor Valéry traz-me à memória outros famosos senhores, como Un certain Plume do grande Henri Michaux ou o senhor Keuner, de Bertolt Brecht. Mas sobretudo convoca o poeta francês Paul Valéry" (José António Gomes, Expresso). 
"O grupo OULIPO de que faço parte apresentou a sua leitura do mês de março no Jussieu, em Paris. Nessa ocasião li a tradução que fiz de duas histórias de O Senhor Valéry: 'Os amigos' e 'A preguiça'” (Jacques Roubaud).

"Um homem: Klaus Klump é uma proeza. Livro terrível, como deve ser a literatura fantasma de nossa época. Livro que não escreve como se fala, mas como se pensa. Ainda estou sob seus efeitos colaterais e tenho medo de fugir de toda ordem doméstica (risos). 'O resto é aquilo que pode morrer ao meu lado. O que pode morrer ao meu lado não sou eu.' Fortíssimo! Poema puro. Tua prosa é um poema apressado. Uma música lenta" (Fabrício Carpinejar, poeta).

"Jerusalém é um grande livro, que pertence à grande literatura ocidental. Gonçalo M. Tavares não tem o direito de escrever tão bem apenas aos 35 anos: dá vontade de lhe bater!" (José Saramago, na cerimônia de entrega do prêmio que leva o seu nome, em 2005). 
ANEXO 4

OBRAS E PREMIAÇÕES DE GONÇALO M. TAVARES

\section{O Reino}

Um homem: Klaus Klump (Caminho, 2003)

A máquina de Joseph Walser (Caminho, 2004)

Jerusalém (Caminho, 2004) - Prêmio José Saramago (2005); Prêmio Ler/Millenium-BCP; Prêmio Portugal Telecom de Literatura (Brasil, 2007) Indicado para o Prix Cévennes para o melhor romance europeu (França, 2009) Aprender a rezar na Era da Técnica (Caminho, 2007) - Prêmio de Melhor Livro Estrangeiro (França, 2010)

\section{O Bairro}

O Senhor Valéry (Escritos, 2004) - Prêmio Branquinho da Fonseca da Fundação Calouste Gulbenkian e do jornal Expresso)

O Senhor Henri (Escritos, 2004)

O Senhor Brecht (Casa da Palavra, 2005)

O Senhor Juarroz (Casa da Palavra, 2007)

O Senhor Kraus (Casa da Palavra, 2007)

O Senhor Calvino (Casa da Palavra, 2007)

O Senhor Walser (Casa da Palavra, 2008)

O Senhor Breton e a entrevista (Casa da Palavra, 2009)

O Senhor Swedenborg (Caminho, 2009)

O Senhor Eliot (Caminho, 2010)

\section{Livros Pretos}

Água, cão, cavalo, cabeça (2006) - Grande Prêmio de Conto Camilo Castelo Branco da Associação Portuguesa de Escritores. 
Uma viagem à Índia (Caminho, 2010)

Prêmio de Melhor Narrativa Ficcional 2010 da Sociedade Portuguesa de Autores

Prêmio Especial de Imprensa Melhor Livro 2010 Ler/Booktailors

Grande Prêmio Romance e Novela da Associação Portuguesa de Autores 2011

Prêmio Fernando Namora/Cassino do Estoril, Melhor Livro Ficção 2011

Prêmio Fundação Inês de Castro

Premiado no Portugal Telecom (Brasil, 2011)

Breves notas sobre ciência (Relógio d'Água, 2006)

Breves notas sobre o medo (Relógio d'Água, 2007)

Breves notas sobre as ligações (Relógio d'Água, 2009)

A perna esquerda de Paris seguido de Roland Barthes e Robert Musil (Relógio d' Água, 2004)

1 (Relógio d'Água, 2004)

Histórias falsas (Campo das Letras, 2005)

A colher de Samuel Beckett, (Campo das Letras, 2003)

Biblioteca (Campo das Letras, 2004)

Livro da dança (Assírio e Alvim, 2001)

Investigações (Novalis-Dífel, 2002)

Prêmio Revelação de Poesia da Associação Portuguesa de Escritores.

Investigações geométricas (Teatro do Campo Alegre, 2005)

\section{PRÊMIOS INTERNACIONAIS:}

Prêmio Portugal Telecom (Brasil, 2007)

Prêmio Internazionale Trieste (Itália, 2008)

Prêmio Belgrado Poesia 2009 (Sérvia, 2009)

Prix du Meuilleur Livre Étranger (França, 2010)

Grand Prix Littéraire du Web (Culture, França, 2010)

Finalista do Prix Femina (França, 2010)

Finalista do Prix Médicis (França, 2010)

Prix Littéraire Européens (Étudiants Francophones, França, 2011) 